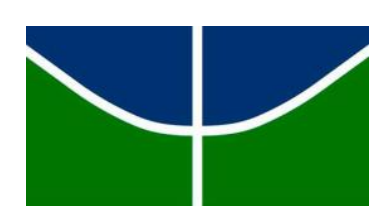

UNIVERSIDADE DE BRASÍLIA

INSTITUTO DE RELAÇÕES INTERNACIONAIS

PROGRAMA DE PÓS-GRADUAÇÃO EM RELAÇÕES INTERNACIONAIS

Jean Santos Lima

\title{
INTERDEPENDÊNCIA E INTEGRAÇÃO \\ NA ERA DAS CADEIAS DE VALOR: \\ LIMITES DA EMERGÊNCIA DO BRASIL
}

(2003-2014)

Brasília

2015 


\section{INTERDEPENDÊNCIA E INTEGRAÇÃO}

NA ERA DAS CADEIAS DE VALOR:

LIMITES DA EMERGÊNCIA DO BRASIL (2003-2014)

Dissertação apresentada ao programa de pós-graduação de Relações Internacionais da Universidade de Brasília, como requisito para obtenção do Título de Mestre em Relações Internacionais.

Área de concentração: Política Internacional e Comparada

Orientador: Prof. Dr. Eduardo José Viola

Brasília 
LIMA, Jean Santos. Interdependência e Integração na Era das Cadeias de Valor:

Limites da Emergência do Brasil (2003-2014). 172 p. Dissertação (Mestrado).

Instituto de Relações Internacionais, Universidade de Brasília, Brasília, 2015.

Aprovada em: 30 de abril de 2015 .

BANCA EXAMINADORA

Prof. Dr. Eduardo José Viola (Orientador)

Instituto de Relações Internacionais

Universidade de Brasília

Prof. Dr. Eiiti Sato

Instituto de Relações Internacionais

Universidade de Brasília

Prof. Dr. Renato Coelho Baumann das Neves

Departamento de Economia

Universidade de Brasília e IPEA

Prof $^{\mathrm{a}}$. Dr ${ }^{\mathrm{a}}$. Maria Helena de Castro Santos (Suplente)

Instituto de Relações Internacionais

Universidade de Brasília 
Para minha família, com imensa gratidão e razões perenes. 
"Quando os ventos de mudança sopram, umas pessoas levantam barreiras, outras constroem moinhos de vento."

Érico Veríssimo

"O que é verdade num tempo, é erro em outro."

Montesquieu 


\section{AGRADECIMENTOS}

A Deus, "primeiro motor imóvel" do imenso universo.

À minha mãe Valdelice, ao meu pai Francisco, à minha irmã Gisele (e ao pequeno João), à minha tia Florenice, à minha avó Djanira, e aos meus demais incontáveis familiares, que tanto me apoiaram e apoiam, e que mesmo nas dificuldades que a vida nos impôs, souberam me demonstrar o valor do caminho da educação, justiça, honestidade e perseverança.

Ao Conselho Nacional de Desenvolvimento Científico e Tecnológico (CNPq/MCTI), pelo imprescindivel apoio financeiro por meio da bolsa de mestrado.

À Universidade de Brasília e aos funcionários do IREL/UnB, pela presteza, disposição e suporte estrutural durante a maior parte do tempo dedicado à elaboração e pesquisa desta dissertação.

Ao meu orientador Dr. Eduardo Viola, que sempre me apoiou e orientou com maestria, compreensão e exímia inteligência, sendo uma fonte de inspiração acadêmica na excelência analítica e na seriedade com que lida com os problemas contemporâneos da humanidade.

Aos meus professores durante o mestrado no Irel/UnB: Dr ${ }^{a}$. Cristina Yumie, Dr. Antônio Jorge Ramalho, e Dr. José Flávio Saraiva. Aos professores Dr. Pio Penna, Dr. Antônio Carlos Lessa e Dr. Daniel Jatobá pelos conselhos e recomendações.

À professora Dra. Maria Helena de Castro e ao professor Dr. Carlos Pio pelas valiosas contribuições, conversas e sugestões que tanto ajudaram a enriquecer o trabalho.

Ao professor Dr. Maurício Barata, do Departamento de Economia da UnB, pelas aulas, conversas, indicações e aprendizado sobre as políticas comerciais.

Ao professor Dr. Eiiti Sato pelas sugestões, conversas e contribuições decorridas de suas participações na qualificação e na defesa de dissertação.

Ao professor Dr. Renato Baumann, pelas aulas, sugestões, conversas e estímulo à pesquisa e à atenção aos substanciais aspectos da economia internacional.

Ao Dr. Fábio Albergaria e ao Dr. Eduardo Rezende da ABDI pelas indicações e recomendações à minha trajetória acadêmica e profissional.

Aos meus inúmeros colegas e amigos que encontrei no Programa de Pósgraduação do IREL/UnB, com os quais tanto aprendi e recebi o apoio para que esse trabalho fosse terminado.

À Clarice, por todo o companheirismo, paciência, afeto, inspiração e suporte essenciais para a elaboração desta dissertação e pelo aprendizado constante.

A todos que me ajudaram de alguma forma e torceram para que eu obtivesse êxito na dissertação. 


\section{RESUMO}

Esta dissertação argumenta que, paradoxalmente à sua emergência como potência regional e, até certo ponto, global (entre 2004 e 2010), o Brasil apresentou um descompasso em sua política comercial externa em relação às grandes mudanças na economia global, notadamente aos novos padrões de comércio internacional de manufaturas. Evidencia-se tal fato a partir da análise comparativa com os demais países emergentes, com base em dados qualitativos e quantitativos e da análise da literatura contemporânea das áreas de Política Internacional e Economia. Adicionalmente, argumenta-se que, embora o cenário econômico internacional tenha sido excepcionalmente favorável à economia brasileira, ao menos até 2011, escolhas realizadas no âmbito doméstico e de política externa contribuíram significativamente para a primarização da pauta exportadora brasileira e para o contínuo isolamento brasileiro dos acordos e mega-acordos preferenciais, bem como das cadeias globais de valor. Do lado da demanda, destacam-se o baixo acesso relativo a mercados mais sofisticados, em razão da aposta quase absoluta no multilateralismo, bem como da falta de avanços significativos no Mercosul, e da priorização das relações com os países ditos do Sul Global. Do lado da oferta, a política macroeconômica de incentivo ao consumo de massa e a distorcida estrutura de proteção comercial limitaram condições estruturais para a inserção competitiva da economia brasileira nas cadeias de valor. O Brasil permanece como uma das economias mais fechadas do mundo, o que se verifica diante da baixa relação comércio/PIB, do nível de barreiras às importações, e da baixa participação no comércio internacional. Conclui-se que há um path dependence quanto a essa baixa inserção do Brasil em termos de integração econômica internacional, em especial da indústria de transformação, resultando em custos de oportunidade e constrangimentos crescentes com o passar do tempo. Essa situação se agrava com a própria evolução das cadeias de valor e com avanços das negociações dos mega-acordos preferenciais Parceria Transatlântica (TTIP) e Parceria Transpacífico (TPP). Num mundo cada vez mais economicamente interdependente, os custos do isolamento e de ações unilaterais excessivamente pró-autossuficiência tornam-se maiores, sobretudo quando não se considera os efeitos nacionais decorrentes de um complexo e amplo quadro internacional, isto é, como a relação entre outros países nos afeta.

Palavras-chave: Política comercial brasileira, integração regional, interdependência econômica, cadeias globais e regionais de valor, acordos comerciais. 


\begin{abstract}
This dissertation argues that Brazil presented a mismatch in its foreign trade policy in relation to major changes in the global economy, notably the new standards of manufactures' international trade, paradoxically to its emergence as a regional power and, to some extent, global power (between 2004 and 2010). This fact is evident from the comparative analysis with other emerging countries, based on qualitative and quantitative data and analysis of contemporary literature of International Politics and Economy. In addition, it is argued that while the international economic environment has been exceptionally favorable to Brazilian economy, at least until 2011, choices previously made on the domestic and foreign policy contributed significantly to the primarization of Brazilian exports and the continued Brazil's isolation of mega trade agreements and global value chains. On the demand side, the highlights are low relative access to more sophisticated markets, due to the almost absolute commitment to multilateralism, to the lack of significant progress in Mercosur, and prioritization of relations with Global South countries. On the supply side, the macroeconomic policy of encouraging mass consumption and the distorted trade protection structure limited framework conditions for competitive insertion of Brazilian economy in value chains. Brazil remains one of the most closed economies in the world, based on the low trade/GDP ratio, the level of import barriers, and low participation in international trade. We conclude that there is a path dependence related to this low insertion of Brazil in terms of international economic integration, especially in the manufacturing industry, resulting in opportunity costs and increasing constraints over time. This situation is aggravated by the development of value chains and the negotiations' progress of preferential mega agreements Transatlantic Trade and Investment Partnership (TTIP) and Trans-Pacific Partnership (TPP). In the increasingly economically interdependent world, the costs of isolation and unilateral actions excessively pro-self-sufficiency become larger, especially when it does not consider the national effects of a complex and broad international framework, i.e., not analyzing how other countries' relations affects us.
\end{abstract}

Keywords: Brazilian trade policy, regional integration, economic interdependence, global value chains, trade agreements. 


\section{LISTA DE FIGURAS}

Figura 1 - Evolução das exportações mundiais de 1950 a 2013

Figura 2 - Crescimento percentual real do PIB mundial, economias avançadas e economias emergentes (variação percentual anual)

Figura 3 - Smile Curve - Estrutura de adição de valor em cadeia produtiva de capital baseado em

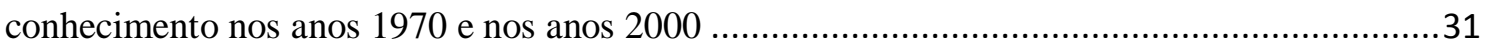

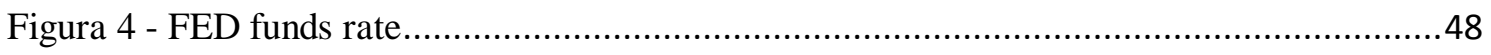

Figura 5 - Taxas de juros de 10 anos do Tesouro dos EUA - médias anuais (\% a.a.)..................49

Figura 6 - Investimentos em carteira no BP do Brasil em US\$ milhões ...................................50

Figura 7 - Entrada de investimento estrangeiro direto (IED) em US\$ bilhões ............................ 51

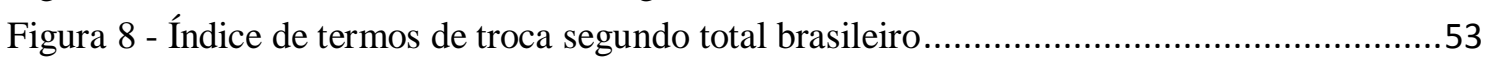

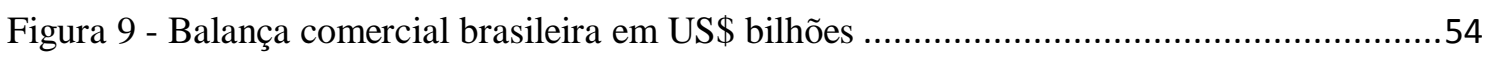

Figura 10 - Evolução do Saldo Comercial em Milhões US\$ .....................................................55

Figura 11 - Resultado do balanço de pagamentos do Brasil em US\$ bilhões .............................56

Figura 12 - Exportação brasileira por fator Agregado de1964 a 2013 ......................................58

Figura 13 - Taxa de câmbio R\$/US\$ média entre compra e venda ...........................................63

Figura 14 - Participação percentual das exportações do Brasil .............................................107

Figura 15 - Evolução dos acordos regionais de comércio notificados pela OMC .....................122

Figura 16 - Comércio exterior (exportações + importações) de bens e serviços como \% do PIB -

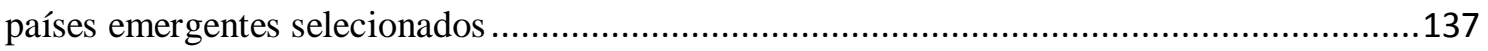

Figura 17 - Comércio como \% do PIB em 2013 de países emergentes selecionados ................142

Figura 18 - Participação nas CGV de 40 países em 2009 .....................................................144

Figura 19 - Valor estrangeiro adicionado nas exportações brutas das 20 maiores economias do

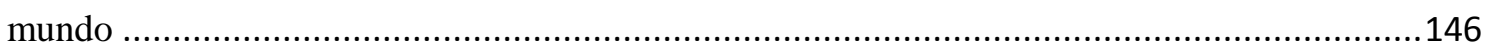

Figura 20 - Participação setorial do Brasil nas CGV em 2009 …........................................147

Figura 21 - Valores domésticos e estrangeiros adicionados ..................................................148

Figura 22 - Parcela de exportações em termos de valor adicionado e exportações brutas de 40

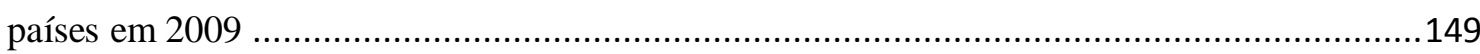




\section{LISTA DE TABELAS}

Tabela 1 - Balança comercial dos EUA em iphones S4 (milhões de dólares US\$) 36

Tabela 2 - Formação bruta de capital fixo como \% do PIB - emergentes selecionados $\quad 69$

Tabela 3 - Comércio intrarregional (\% das exportações) em $2010 \quad 104$

Tabela 4 - Principais mercados de origem das exportações e das importações do Brasil 106

Tabela 5 - Importações dos demais países do Mercosul provenientes do Brasil e da China em 2009 e 2013

Tabela 6 - Número de acordos comerciais em vigor assinados por emergentes selecionados 117

Tabela 7 - Tarifa ponderada para importações de bens de capital - Brasil e emergentes $\quad 132$

Tabela 8 - Tarifa ponderada para importações de bens intermediários - Brasil e emergentes 134

Tabela 9 - Tarifa ponderada para importações de bens manufaturados* - Brasil e emergentes 135

\section{LISTA DE QUADROS}

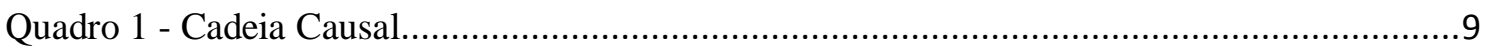

Quadro 2 - Mudanças na percepção da política internacional, antes e depois das CGV .............41

Quadro 3 - Liberdade Econômica - AP e Mercosul ..............................................................101

Quadro 4 - Ambiente de Negócios - AP e Mercosul .............................................................101

Quadro 5 - Índice de Competitividade Global - AP e Mercosul...............................................102

Quadro 6 - Linha do tempo da emergência do Brasil 2001 a 2014.........................................153 


\section{SIGLAS E ABREVIAÇÕES}

ABDI - Agência Brasileira de Desenvolvimento Industrial

ALBA - Aliança Bolivariana para as Américas

ALCA - Acordo de Livre Comércio das Américas

AMCHAM/Brasil - Câmara Americana de Comércio Exterior no Brasil

AP - Alianza del Pacífico

APC - Acordo de Preferência Comercial

APEX - Agência Brasileira de Promoção de Exportação e Investimentos

ARC - Acordo Regional de Comércio

ASEAN - Associação das Nações do Sudeste Asiático

BC, BCB - Banco Central do Brasil

BID - Banco Interamericano de Desenvolvimento

BNDES - Banco Nacional de Desenvolvimento Econômico e Social

BNT - Barreiras não tarifárias

BP - Balanço de Pagamentos

BRICs - Brasil, Rússia, Índia e China

CAMEX - Câmara de Comércio Exterior

CAN - Comunidade Andina

CARICOM - Comunidade do Caribe

CEPAL - Comissão Econômica para a América Latina e o Caribe

CGV - Cadeia Global de Valor

CNI - Confederação Nacional da Indústria

COSIPLAN - Conselho Sul-Americano de Infraestrutura e Planejamento

Embraer - Empresa Brasileira de Aeronáutica S.A

EUA - Estados Unidos da América

FBCF - Formação Bruta de Capital Fixo

FED Funds - Federal Reserve Funds (Títulos do Banco Central Americano)

FIESP - Federação das Indústrias do Estado de São Paulo

FMI - Fundo Monetário Internacional

FOCEM - Fundo de Convergência Estrutural do Mercosul

FTAA - Free Trade Area of the Americas

FUNCEX - Fundação Centro de Estudos do Comércio Exterior

GATT - General Agreement on Tariffs and Trade 
IBGE - Instituto Brasileiro de Geografia e Estatística

IED - Investimento Estrangeiro Direto

IIRSA - Iniciativa de Integração da Infraestrutura Regional Sul-americana

INDEC - Instituto Nacional de Estadística y Censos de la República Argentina

IPEA - Instituto de Pesquisa Econômica Aplicada

LAC - Latin American Countries

MDIC - Ministério do Desenvolvimento, Indústria e Comércio Exterior

Mercosul - Mercado Comum do Sul

MILA - Mercado Integrado Latino Americano

NAFTA - North American Free Trade Organization

NBER - National Bureau of Economic Research

NICs - Newly Industrialized Countries (Países de Industrialização Tardia ou Recente)

OCDE - Organização de Cooperação e Desenvolvimento Econômico

OECD (OCDE) - Organisation for Economic Co-operation and Development

OMC - Organização Mundial do Comércio

OSC - Órgão de Solução de Controvérsias da OMC

P\&D - Pesquisa e Desenvolvimento

PIB - Produto Interno Bruto

PME - Pequena e média empresa

R\&D - Research and Development

SECEX - Secretaria de Comércio Exterior

SGP - Sistema Geral de Preferências

SICA - Sistema de la Integración Centroamericana

SITC - Standard International Trade Classification

TEC - Tarifa Externa Comum

TISA - Secret Trade in Services Agreement.

TLC - Tratado de Livre Comércio

TPP - Trans-Pacific Partnership (Parceria Trans-Pacífico)

TTIP - Transatlantic Trade and Investment Partnership (EUA + UE) (Parceria

Transatlântica)

UA - União Aduaneira

UE - União Europeia

UNASUL - União de Nações Sul-Americanas

UNCOMTRADE - The United Nations Commodity Trade Statistics Database 
WB - World Bank

WEF - Word Economic Forum

WITS - World Integrated Trade Solution

WTO - World Trade Organization 


\section{ÍNDICE}

INTRODUÇÃ

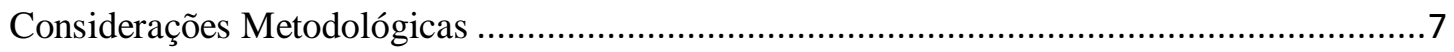

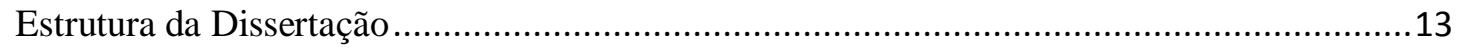

CAPÍTULO 1 - A NOVA ECONOMIA POLÍTICA INTERNACIONAL, A

INTERDEPENDÊNCIA CRESCENTE E AS CADEIAS GLOBAIS DE VALOR ...................15

1.1. A Nova Economia Política Internacional: Principais Questionamentos e Mudanças .......15

1.2. As Grandes Mudanças na Economia Global................................................................18

A Ascensão Econômica da Ásia- Pacífico..........................................................................18

A Evolução do Comércio Internacional e as Economias de Escala ...................................21

A Globalização Contemporânea e o Surgimento das Cadeias Globais de Valor .................23

A Obsolescência dos Regimes Internacionais e de Estatísticas de Comércio Exterior ........35

Os Avanços Tecnológicos e os Desafios para a Inserção nas CGV .....................................36

1.3. As Teorias Tradicionais de EPI e os Novos Padrões de Comércio Internacional .............39

1.4. A Crescente Interdependência Econômica e a Assimetria de Ganhos .............................41

CAPÍTULO 2 - O CENÁRIO INTERNACIONAL FAVORÁVEL E A PRIMARIZAÇÃO DA

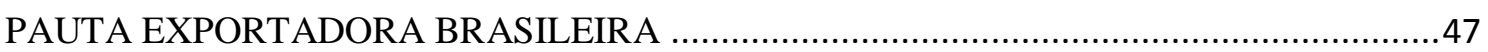

2.1. O Cenário Econômico Internacional Favorável ......................................................47

a) As Baixas Taxas de Juros Internacionais e a Entrada de Investimentos no Brasil ..........48

b) A Reversão nos Termos de Troca do Comércio Exterior Brasileiro ................................52

2.2. A Primarização da Pauta Exportadora Brasileira ……………......................................57

2.3. As Políticas Industriais no Brasil no Século XXI e Seus Questionamentos .....................63

2.4. A Formação Bruta de Capital Fixo como Diferencial de Competitividade ......................68

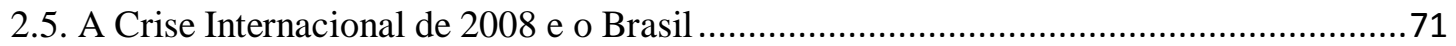

CAPÍTULO 3 - REGIONALISMOS NA ERA DAS CADEIAS DE VALOR E OS DILEMAS CONTEMPORÂNEOS DA INTEGRAÇÃO SUL-AMERICANA ..........................................76

3.1. O Regionalismo "Pós-Hegemônico" após o Colapso da ALCA .......................................76

3.2. Os Dilemas Contemporâneos do Brasil no Mercosul .......................................................... 81

a) Os Desafios para a Construção de uma Cadeia de Valor Regional .................................81

b) O Trade-off do Estágio de Integração: entre a União Aduaneira Imperfeita e a Área de

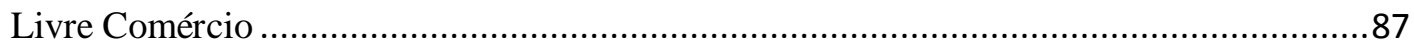

c) A Questão da Soberania no Mercosul ........................................................................91

d) A Emergência da Aliança do Pacífico e o Contraste com o Mercosul .............................96

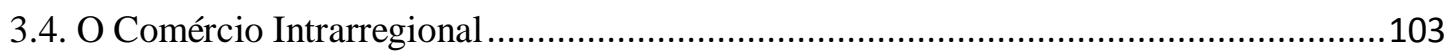


3.5. Padrões de Liderança em uma Integração Econômica Regional. 109

3.6. A Integração Latino-Americana e a do Leste Asiático: Experiências Destoantes 112

CAPÍTULO 4 - A POLÍTICA COMERCIAL EXTERNA BRASILEIRA E AS DINÂMICAS

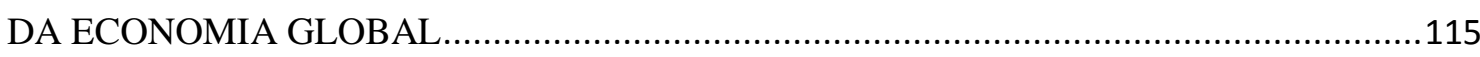

4.1. A Política Externa Brasileira e o Isolamento do Brasil dos Acordos Comerciais ...........115

4.2. As Negociações dos Mega-Acordos e a Passividade Brasileira.....................................120

a) A Aposta no Multilateralismo e a Estagnação da Rodada Doha .....................................120

b) As Negociações do TTIP e TPP e o Brasil ..............................................................124

4.3. A Estrutura de Proteção Tarifária do Brasil ...............................................................130

4.6. A Evolução do Valor do Comércio Sobre o PIB de Países Emergentes Selecionados ..136

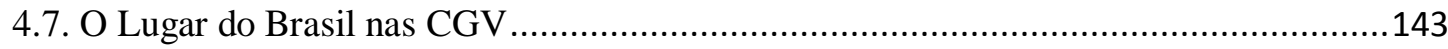

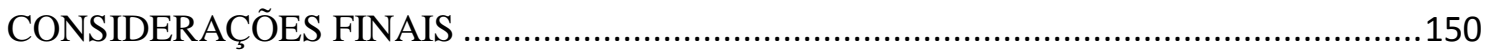

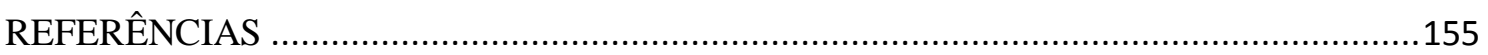




\section{INTRODUÇÃO}

O ano de 2014 foi um ano de preocupações para o desempenho externo da economia brasileira. O Brasil apresentou déficit comercial pela primeira vez desde 2000, quando as importações superaram as exportações em US\$ 3,9 bilhões, também sendo o maior déficit desde 1998, quanto este atingiu o valor de US\$ 6,6 bilhões (MDIC, 2015). Em 2013, o País apresentaria déficit no balanço de pagamentos, algo que não acontecia desde o ano 2000. O setor industrial (em especial a indústria de transformação), fonte de externalidades positivas derivadas do progresso técnico para a economia nacional, tem perdido continuamente participação na pauta de exportação brasileira, o que faz suscitar argumentos de que o país estaria padecendo de um processo de "desindustrialização" (BACHA; BAUMGARTEN, 2015; BAUMANN, 2013b). Em estudo realizado pela Confederação Nacional da Indústria (CNI), "Competitividade Brasil 2014", que compara a competitividade industrial brasileira com a de catorze países de economias consideradas comparáveis à economia brasileira, o Brasil encontra-se na penúltima posição no ranking $\left(14^{\mathrm{a}}\right)$, à frente apenas da Argentina ${ }^{1}$, maior parceiro comercial regional do País (CNI, 2014).

Além do baixo desempenho industrial, no plano doméstico, o Brasil tem apresentado nos últimos anos um baixo crescimento do PIB. De acordo com dados do IBGE, após o crescimento de 7,5\% em 2010 provocado por políticas de expansão da demanda agregada, o país apresentou taxa de crescimento de 2,7\% em 2011, $1 \%$ em 2012, 2,5\% em 2013 e 0,1\% em 2014. O crescimento praticamente nulo da economia brasileira em 2014 esteve abaixo, inclusive, da estimativa de 0,3\% divulgada pelo Fundo Monetário Internacional (FMI) em seu relatório World Economic Outlook, lançado em outubro de 2014, e bem abaixo da média global de 3,3\%. Dentre as razões destacadas pelo relatório para esse baixo desempenho econômico brasileiro, estão "[a] baixa competitividade, a baixa confiança dos empresários e [as] condições financeiras mais 'apertadas' com a alta da taxa de juros" (IMF, 2014, p. 56). O problema adicional a esse baixo crescimento é a redução da renda per capita do país em 2014, com uma

\footnotetext{
${ }^{1}$ Posição competitiva em ordem decrescente dos quinze países selecionados "por suas características econômico-sociais e/ou por seu posicionamento no mercado internacional": Canadá, Coreia do Sul, Austrália, China, Espanha, Chile, África do Sul, Rússia, Polônia, Índia, Turquia, México, Colômbia, Brasil e Argentina. "Dentre os oito fatores de competitividade considerados, o Brasil encontra-se no terço superior apenas em Disponibilidade e custo da mão de obra. No fator Tecnologia e inovação, o Brasil situa-se no terço intermediário e em todos os demais no terço inferior" (CNI, 2014).
} 
variação percentual real de $-0,7 \%$, a segunda maior verificada desde 2009 , ano de efeitos mais profundos da crise recente $(-1,3 \%)$.

Após o relativo declínio do ambiente internacional favorável ao Brasil vivido de 2003 até meados de 2011, uma preocupação que tem ganhado contornos mais alarmistas por parte dos analistas de economia e política internacional é sobre os rumos da política comercial externa e a visão brasileira de inserção econômica internacional. Conforme o Diretor da Fundação Centro de Estudos do Comércio Exterior (FUNCEX), Ricardo Markwald (2013), há um aumento da conscientização da sociedade brasileira em relação ao isolamento do Brasil do comércio internacional, o que faz com que o País permaneça à margem das principais dinâmicas da economia global. Dentre essas dinâmicas, destacam-se a proliferação de acordos comerciais preferenciais que deram origem às negociações dos mega acordos, Trans-Pacific Partnership (TPP) e Transatlantic Trade and Investment Partnership (TTIP), e a evolução do comércio internacional via fragmentação e dispersão da produção, o que deu origem às Cadeias Globais de Valor (CGV). Ainda de acordo com Markwald (2013, p. 15), "(...) cresceu também a percepção dos custos da não participação em acordos comerciais mais abrangentes, assim como os riscos de erosão de nossas preferências em âmbito regional".

Em seu livro Breakout Nations: In Pusrsuit of the Next Miracle Economics (2012), o autor indiano Ruchir Sharma questiona o otimismo em relação ao crescimento sustentado e ascendente dos grandes mercados emergentes no mundo pós-crise 2008/2009. O ano de 2003 é retratado nas palavras do autor como o "ano milagroso" ( the miracle year), uma espécie de critical juncture, ou momento-chave para a história contemporânea dos emergentes, que atraíram repentinamente grandes influxos de riqueza. Entre 2003 e 2007, de acordo com o autor, dobrou-se a taxa média de crescimento do PIB dos quatro grandes países do acrônimo BRIC de 3,6\% das duas décadas anteriores para 7,2 (SHARMA, 2012, p. 4). Entretanto, esse crescimento passou a ser questionado diante dos problemas estruturais de países emergentes que não haviam sido resolvidos durante boa parte da primeira década do século XXI, reforçado por certo recuo do ambiente internacional amplamente favorável. A ausência de reformas estruturais ou sua descontinuidade também é considerada por analistas como um dos motivos para a redução do ritmo de crescimento (CANUTO, 2015) ${ }^{2}$.

\footnotetext{
${ }^{2}$ Em entrevista para o site O Globo, Canuto afirmou que "a expectativa de que os países poderiam continuar a crescer dependia de reformas estruturais. E a agenda de reformas perdeu fôlego em Brasil,
} 
No capítulo referente ao Brasil, Sharma (2012) interroga "Is God Brazilian?". O motivo de tal questionamento é o retorno da inflação ao País, acompanhada da redução do crescimento, contrariando muitas estimativas. Fato é que o Brasil passou por outros momentos de euforia econômica em sua história, a exemplo do "milagre econômico" do fim da década de 1960 e primeira metade da década de 1970 durante o regime militar, no qual havia um forte otimismo em relação à economia do País, o qual chegou a crescer a dois dígitos por quatro anos seguidos ${ }^{3}$. Além dos problemas aliados à gestão brasileira ao tratar do "trilema econômico" - na tentativa de gerir e estabilizar a taxas de juros (e outras políticas macroeconômicas anticíclicas), a taxa de câmbio e ao mesmo tempo manter a liberdade de capitais - o Brasil tem acumulado sucessivos déficits na conta corrente (BACHA, 2013; SHARMA, 2012).

Uma série de analistas ${ }^{4}$ tem apontado para uma preocupação crescente com a condução brasileira do setor externo da economia nacional, além da falta de acompanhamento por parte do governo brasileiro e de parte da sociedade brasileira das mudanças na economia global no século XXI. Se, por um lado, o Brasil é um dos grandes receptores de Investimento Estrangeiro Direto - ao qual ainda permanece aberto e ocupa a quarta posição de maior receptor do mundo, atrás apenas de Estado Unidos, China e Hong Kong - e de capitais financeiros, por outro lado, em matéria comercial, é um dos países mais fechados do mundo. Esse é justamente um fator determinante, muitas vezes levantado por analistas para o baixo grau de inserção do Brasil no comércio internacional, pois no caso brasileiro (assim como Índia e China, por exemplo), diferentemente da ampla maioria de nações, não há uma dependência clara de acordos comerciais para a atração de investimentos, um de seus benefícios defendidos por economistas como Anne Krueger e Jagdish Bhagwati. Além da baixa participação do comércio exterior sobre o PIB brasileiro (não passa dos 28\%), há também, em virtude disso, uma baixa integração do Brasil no comércio internacional, o que, por sua vez, fez com que o País deixasse de acompanhar as mudanças estruturais na economia global. Essas mudanças envolvem desde a intensificação do comércio e produção

Turquia, Rússia e Indonésia e foi postergada na China. No Brasil, não houve criação de novo leque de reformas desde o $2^{\circ}$ mandato de Lula" (CANUTO, 2015).

${ }^{3}$ De acordo com dados do IBGE, o Brasil cresceu 10,4\% em 1970; $11.3 \%$ em 1971; 11,9\% em 1972; e 14\% em 1973.

${ }^{4}$ Para citar alguns: Alexandre Schwartsman, André Lara Resende, Edmar Bacha, Eduardo Giannetti, Eduardo Viola, Eiiti Sato, Fábio Giambiagi, Ilan Goldfan, José Mendonça de Barros, Marcelo de Paiva Abreu, Paulo Roberto de Almeida, Renato Baumann e Sérgio Amaral. As críticas dos autores referidos não se restringem à condução do setor externo da economia nacional, mas também às opções de política macroeconômica domésticas. 
internacional via valor adicionado, até a economia do aprendizado ${ }^{5}$, que pode ser dificultada pelas barreiras impostas à aquisição ou assimilação de novas sofisticações tecnológicas (OECD; WTO; UNCTAD, 2013; NADEAU, 2014).

Há fatores explicativos de ordem interna e de ordem externa para essa baixa participação do Brasil nas CGV. De ordem interna, são tratadas as deliberações nacionais para o âmbito doméstico e para o âmbito externo. Fatores de ordem externa, também tratados aqui como eventos exógenos, são acontecimentos ou fenômenos que não estão sob o domínio da sociedade brasileira, mas que de alguma forma a afetam.

No âmbito da política externa brasileira no período 2003-2014, foram priorizadas as relações comerciais entre os Estados-membros do Mercosul em detrimento de negociações comerciais extrabloco, sobretudo após o colapso do projeto do Acordo de Livre Comércio das Américas em 2005 em Mar del Plata. Há uma série de analistas que questiona o percurso recente do Mercosul para atingir os objetivos delineados no Tratado de Assunção de 1991, como o da liberalização gradual e evolutiva entre os membros para a formação futura de um mercado comum (ZANOTTO, 2014). Questiona-se também o vínculo mantido pelo Brasil com os vizinhos e um possível entrave resultante das negociações do País com outros processos de integração, além da falta de um organismo claro e eficiente para solução de controvérsias dentro do bloco (ALMEIDA, 2013a; BAUMANN, 2013a).

O Mercosul marca um contraste com a recente iniciativa da Aliança do Pacífico. Muito tem se debatido sobre os dois modelos de integração, ao tratar-se do Mercosul como uma espécie de "fortaleza comercial", muito restrita em termos de acesso a mercados, dado o número limitado de acordos, e do modelo de "regionalismo aberto" da Aliança do Pacífico - que por sua vez era um dos princípios norteadores de ação do próprio Mercosul na década de 1990 - o qual enseja, argumenta-se aqui, uma unificação mais eficaz em termos de liberalização e negociações multilaterais, preferenciais (seja regional ou bilateral) e unilaterais. Embora tenha diversos desafios para a integração, como a falta de complementaridade produtiva dos quatro países - Chile, Colômbia, México e Peru - a própria emergência da Aliança do Pacífico ajudou a evidenciar a falta de avanços no Mercosul para a solução institucional e para a integração econômica de seus membros, além da baixa inserção nos novos padrões de comércio internacional.

\footnotetext{
${ }^{5}$ Autores como Stiglitz e Greenwald (2013) defendem que o fomento da produção industrial é fonte de externalidades positivas para o restante da economia e de criação de uma sociedade do aprendizado, dadas as variadas possibilidades de progresso técnico que não se encontram no setor primário.
} 
Ainda no contexto das opções de política externa, agora no âmbito multilateral, com a ascensão dos emergentes e o declínio relativo dos Estados Unidos como superpotência (ZAKARIA, 2008), o Brasil obteve maior espaço e influência nas altas instâncias da Governança Global, em especial no G-20, grupo que reúne as 20 maiores economias do globo e que ganhou forte destaque após a crise econômico-financeira de 2008 ao evitar um derretimento do sistema financeiro internacional (VIOLA; FRANCHINI; RIBEIRO, 2013). O País também despontou nos principais periódicos internacionais como membro do agrupamento BRICs, que enseja certo revisionismo das relações econômicas internacionais e aspira por maior participação em organismos como o Fundo Monetário Internacional e o Banco Mundial. Segundo Hurrell (2009) e Laidi (2012), os países do BRICs possuem como elemento de coesão o resguardo da soberania nacional, refletido tanto no desejo de reconhecimento pelas grandes potências ocidentais de um mundo pluralista e multipolar em termos de justiça e equidade, quanto na penosa defesa da não interferência nos assuntos internos.

Esse posicionamento em defesa de uma coalizão Sul-Sul pode influenciar o afastamento econômico de nações ocidentais, a exemplo de negociações multilaterais e bilaterais mais árduas em matéria comercial, A própria divisão conceitual do mundo em Norte e Sul, apesar de deter ainda alguma utilidade como categoria analítica, não representa claramente a realidade das relações entre os países no século XXI, ou suas diferenças de força e peso econômico, muito menos o nível de sofisticação atual de nações até pouco tempo consideradas em desenvolvimento. Por essa razão, torna-se mais apropriada a classificação de nível de desenvolvimento em países desenvolvidos, emergentes e menos desenvolvidos, ou mesmo por critério de faixa de renda média per capita.

No âmbito da política doméstica, por opção do governo federal, o Brasil optou por uma política de retorno ao desenvolvimento do mercado interno via políticas e ideias intervencionistas (CARDOSO, R., 2010). Medidas como o fornecimento de crédito ao consumo de massa pelos bancos públicos e de economia mista, com valorização do salário real, ajudaram a reduzir a desigualdade de renda no país. Entretanto, essa política foi intensificada a partir de 2010, combinada com a continuidade da adoção de barreiras tarifárias comerciais relativamente elevadas para o nível de desenvolvimento da economia brasileira. Essas decisões parecem não ter surtido grandes efeitos positivos em indicadores que demonstram melhora na estrutura da economia brasileira e na sustentabilidade do desenvolvimento. Apesar dos esforços e 
interferências governamentais envidados, houve um declínio da produtividade do trabalho da indústria de transformação (SQUEFF, 2012), uma contínua baixa competitividade industrial global (WEF, 2014), além de uma relativa baixa taxa de investimento (World Bank Data, 2013). O cenário de inflações acima da meta é mais uma evidência do resultado dessa opção política.

A experiência internacional demonstra que o comércio exterior assume uma função determinante para os países que superem a "armadilha da classe média", ou seja, que alcancem uma alta renda per capita após diversos anos e décadas estagnado na faixa de renda média. Além da tendência de países mais abertos ao comércio experimentarem maior crescimento da produtividade (EDWARDS, 1997), conforme relatado por Edmar Bacha (2014), Israel, Coreia do Sul, Taiwan, Hong Kong e Cingapura apoiaram-se nas exportações industriais para alcançar o primeiro mundo; Espanha, Grécia, Portugal e Irlanda apoiaram-se nas exportações de serviços e de mão de obra; outras nações como Austrália e Nova Zelândia conseguiram livrar-se da "maldição dos recursos naturais" e tornaram-se exportadores de commodities. Diante disso, de maneira indutiva, discorrese aqui que para que o Brasil transite de uma nação de renda média para uma de renda elevada dentre outros fatores como o de detentor de uma maior sofisticação tecnológica, o país deve se inserir de forma mais eficaz e ascendente no comércio internacional.

Por diversos momentos nesta dissertação, compara-se a trajetória recente do Brasil em determinados aspectos da política econômica externa com outros países emergentes, notadamente aqueles também inseridos no acrônimo BRIC - Rússia, Índia e China - bem como mercados e sociedades ascendentes, como México, Turquia e Indonésia. A Coreia do Sul é um caso exemplar de país que superou a barreira do subdesenvolvimento e da armadilha da classe média muito em virtude do comércio com outras nações (adotando um modelo outward oriented) e, por isso, também em certas ocasiões é um caso utilizado como parâmetro de sucesso.

Este não é um estudo que busca primariamente erigir uma crítica à emergência do Brasil nessa primeira década e meia do século XXI em sentido estrito, mas que tem como objetivo analisar fatores e políticas limitadores da inserção externa competitiva, os quais se configuram como limites à emergência e ascensão do Brasil. Isso se torna mais evidente no exercício de uma análise comparativa com os demais países considerados emergentes, ao constatar-se que o Brasil posiciona-se nas últimas colocações dos indicadores analisados - peso do comércio exterior sobre o PIB, taxa de investimento (formação bruta de capital fixo), participação nas Cadeias Globais de 
Valor, isolamento nos acordos e mega acordos preferenciais e limitações relativas no "padrão de liderança regional" em matéria econômica e produtiva.

\section{Considerações Metodológicas}

O método analítico utilizado na pesquisa é, em parte, também uma das explicações pela qual o Brasil não acompanhou no século XXI as mudanças da economia global: path dependence. A importância do uso desse método está no pressuposto de que, em determinado momento, um agente (que, no caso desta pesquisa, trata-se da unidade de análise "sociedade \& governo brasileiro") tinha a seu dispor opções de políticas que o vinculariam a um padrão de ação e influenciariam os acontecimentos correlacionados à decisão tomada. O path dependence é um método analítico que ajuda na explicação de um desdobramento de estágios sequenciais cujos avanços podem fechar alternativas de ação.

Em outras palavras, ao fazer uma escolha, outras se fecham e com o passar do tempo os constrangimentos resultantes daquela decisão tornam-se cada vez maiores (BENNETT; ELMAN, 2006). O momento chave ou decisão central, que cria um curso de ação e determina em grande medida o futuro, é denominado pela literatura de critical juncture. Essa pode ser considerada para o fenômeno estudado - baixa integração do Brasil no comércio internacional - como o ano de 2003 e o cenário internacional que proporcionou uma bonança econômica conjuntural (SHARMA, 2013; BACHA, 2014). Essa decisão se enquadra em um período de mudança significativa. A decisão de continuar com uma política desenvolvimentista com proteção do mercado interno faz com que o país pague um alto custo por seguir esse curso de ação. Conforme Bennett e Elman:

A common characteristic of path dependence is that constraints increase as time goes by. After contingent events have selected a particular path, actors are constrained to remain on that path or forced to pay a higher price to leave it by a variety of mechanisms that make it more plausible or attractive than other alternatives. Hence, it often follows that perturbing causes will have bigger effects the sooner they happen (2006, p. 464).

Como afirma Odell (2001, p.167), praticamente todos os estudos de caso de alguma maneira descrevem um processo dinâmico - seja mudança política, conflitos, 
negociações, processo de tomada de decisão e aceitação de normas, etc. Desse ponto de vista, o método do process tracing e do path dependence, que apresentam semelhanças, são muito mais técnicas que envolvem a análise de um estudo de caso, do que propriamente um método de pesquisa (ODELL, 2001, p. 167).

Duas perguntas nesse estudo de caso analisado por meio do path dependence são centrais na dissertação: Que fatores domésticos e opções de política externa fizeram com que o Brasil não acompanhasse as principais grandes mudanças na economia global neste século XXI? ; e, apesar de destacar-se como potência emergente, por que o Brasil permanece com uma baixa integração produtiva e comercial na economia global? Testa-se a hipótese diretiva delineada na cadeia causal, de que: opções nacionais (previous policy choices) $^{6}$ - priorização por proteção do mercado interno, falta de avanços na integração comercial e produtiva sul-americana, aposta quase absoluta no multilateralismo - fizeram com que o Brasil não acompanhasse as principais mudanças estruturais na economia global (international setting), contribuindo para uma relativa baixa integração internacional da economia brasileira (outcome).

Fatores externos (exogenous effects) como o cenário internacional amplamente favorável também contribuíram para esse processo, na medida em que tenham gerado uma acomodação aos fluxos da década anterior sem realizar as reformas necessárias para a continuidade do desenvolvimento de longo prazo, e sem um apoio deliberado à inserção internacional do setor manufatureiro.

A definição das variáveis neste estudo está baseada nas acepções de Johnson \& Reynolds (2012, p.103): a variável independente é um fenômeno que nós acreditamos que nos ajudará a explicar características políticas ou comportamentos, em outras palavras, são as mensurações do fenômeno que se supõe que influenciam, afetam, ou causam outro fenômeno; a variável dependente supõe-se ser causada, dependente de, ou ser uma função de variável independente.

Como informam os autores (JOHNSON; REYNOLDS, 2012, p. 104), pesquisadores podem adicionar explicações de como as variáveis independentes estão relacionadas à variável dependente, determinar quais variáveis independentes ocorrem antes de outras variáveis independentes e indicar quais delas possuem um efeito mais direto no fenômeno no qual se tenta explicar (variável dependente). Segundo os

\footnotetext{
${ }^{6}$ As expressões encontram-se em destaque apenas como referência às variáveis e elementos corriqueiros nas explicações causais nos estudos de economia política internacional (Conf. FRIEDEN; MARTIN, 2003).
} 
autores, a variável interveniente é a variável que ocorre próxima do tempo à variável dependente e é em si afetada por outras variáveis independentes.

Tendo em vista que a realidade internacional é sempre "multicausal", especialmente os fenômenos econômicos - pois englobam diversas conjunturas nacionais, diversos grupos domésticos com interesses convergentes e divergentes - a proposta abaixo é uma tentativa de simplificação da realidade para alguns determinantes da baixa integração do Brasil no comércio internacional no século XXI. Seguindo o conselho de Johnson e Reynolds, segue abaixo a cadeia causal (arrow diagram), como um indicação apropriada para apresentar e manter o controle de explicações ligadas à variável dependente.

\section{Quadro 1 - Cadeia Causal}
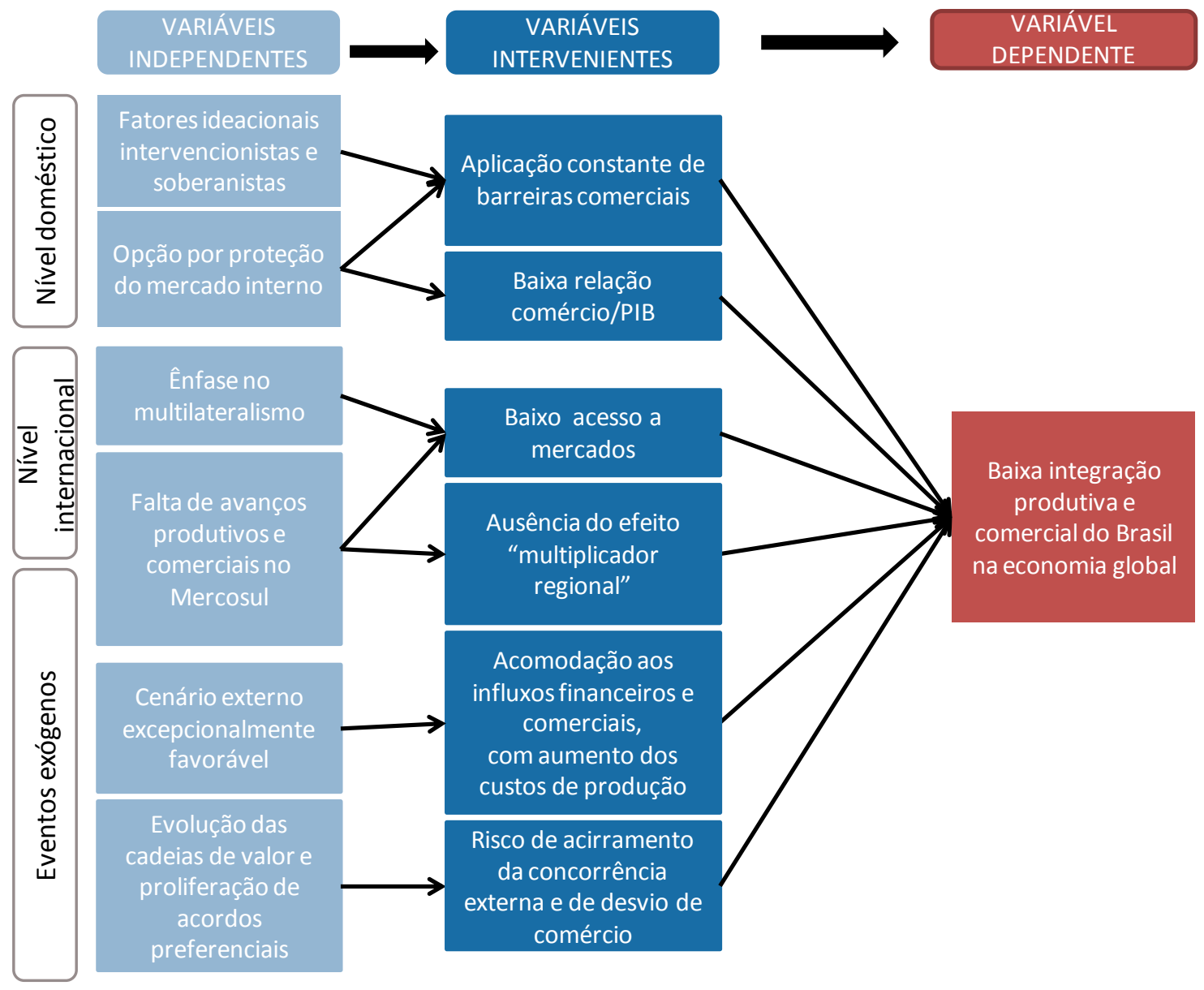

Fonte: elaboração própria.

O nível doméstico refere-se às adoções de políticas no Brasil e do perfil histórico do país em termos de visão de mundo e visão de si diante do mundo. Como nação de grandes proporções geográficas e dotada de vasta gama de recursos naturais, o Brasil 
historicamente tem adotado uma inserção externa com grande resguardo da soberania e, no século XXI, após 2003, tem reforçado essa visão por meio das coalizões BRICs e IBAS, por exemplo. Atrelado a esse perfil, o comércio exterior tem sido atividade secundária no que concerne à política externa, já que o Brasil tem sido um país voltado para o fomento do mercado interno desde 2003, sob uma espécie de modelo inward looking. Adicionalmente, a integração internacional promove restrições à autonomia nacional no tocante a políticas anticíclicas por parte dos governos nacionais (embora seja preferível, como se verá mais adiante), e por essa e outras razões é vista com cautela por algumas elites políticas.

Ainda no nível doméstico, a resposta à crise demandou instrumentos keynesianos de incentivo à demanda agregada, mas que por sua vez, foram intensificados com a eleição de Dilma Rousseff para presidente do Brasil em 2010, com o incentivo ao consumo de massa. O nível de barreiras tarifárias comerciais, como também se verá, teve continuidade, reforçadas pelas políticas industriais implantadas desde 2004, no governo Lula. Muitos dos resultados do período (2003-2014) não são animadores para a produtividade da indústria de transformação, tampouco para a base material para o crescimento de longo prazo - a taxa de crescimento da Formação Bruta de Capital Fixo, e da produção industrial, fonte tanto de empregos qualificados como do incentivo à aprendizagem e conhecimento na economia (STIGLITZ; GREENWALD, 2014).

Ao lado da intensificação do processo de globalização no século XXI, há uma crescente atividade produtiva e comercial via proliferação de acordos preferenciais de comércio em nível regional, incentivando os regionalismos. Os mercados regionais são tradicionalmente fontes primárias das atividades econômicas e comerciais, por mais que tenham se avançado as transformações tecnológicas e de comunicações, a geografia é um fator a considerar, pois os custos de transporte e o grau de integração prévia de países ainda fazem a diferença nos projetos de inserção internacional.

O Brasil tem no mercado regional um espaço muito importante para as exportações de bens manufaturados. Cerca de $73 \%$ das exportações do País para a América Latina e Caribe é composta por bens manufaturados. Essa região possui a maior participação dentre as demais no total exportado pelo Brasil nesse quesito. Muitos analistas sugerem que o Mercosul, principal acordo comercial brasileiro, afastou-se dos objetivos originais do bloco e o projeto de integração ganhou contornos mais políticos desde 2003 (ALMEIDA, 2013a; AMARAL, 2013; BARBOSA, 2013; BAUMANN, 
2013b; MAGNOLI, 2013; MARKWALD, 2013; THORSTENSEN, 2014; ZANOTTO, 2014). Soma-se a isso o alargamento de temas no bloco, com destaque à criação do Parlamento do Mercosul e do Fundo de Convergência Estrutural (FOCEM), os quais possuem impacto muito limitado em termos de uma governança regional mais democrática e de redução das assimetrias. O Mercosul também enfrenta dificuldades institucionais, muitas delas decorrentes da relutância de Brasil, Argentina e Venezuela em abdicar parcialmente da soberania nacional para o projeto de integração, reforçada pelo modelo intergovernamental do bloco. Dificuldades macroeconômicas como as crises argentina e venezuelana e, até certo ponto, a brasileira, também são obstáculos para avançar-se em matéria de liberalização comercial e produtiva no bloco. Ademais, enquanto o Brasil ostenta a maior economia regional, o perfil de liderança brasileira no Mercosul não corresponde adequadamente ao padrão exercido por outras nações para a criação e evolução de cadeias regionais de valor.

Eventos exógenos ao Brasil também impactaram negativamente a integração produtiva e comercial do País no cenário internacional. O alto crescimento da China, bem como de seu comércio exterior, apresentado em especial após a entrada do país na Organização Mundial do Comércio (OMC), em 2001, provocaria mudanças consideráveis nos preços de produtos comercializáveis na economia global. Para abastecer a crescente população urbana, a China aumentou consideravelmente a demanda por commodities, elevando o seu preço e consequentemente as exportações de seus fornecedores, dentre os quais, o Brasil e Argentina. Devido à redução de tarifas internacionais e maior produção chinesa, os produtos industriais tornaram-se, por sua vez, mais baratos no comércio internacional, provocando assim uma reversão dos termos de troca do Brasil (isto é, elevação dos preços internacionais dos produtos dos quais o País é exportador e redução dos preços dos produtos dos quais o País é importador). Além desse aspecto, cabe destacar que os juros internacionais mais baixos que os encontrados no Brasil também favoreceram a atração de capitais financeiros para o País, incentivando os detentores de capitais a investir no mundo emergente.

Há, contudo, uma espécie de "efeito colateral" (BACHA; BAUMGARTEN, 2013) da bonança externa vivida pelo Brasil, pois o setor industrial, em especial o de manufaturados, perdeu espaço na pauta exportadora do País, retornando a níveis do fim dos anos 1970. Tornaram-se frequentes o levantamento de hipóteses como "doença holandesa", "maldição dos recursos naturais", "desindustrialização" e "primarização da pauta exportadora" por parte de analistas nacionais e estrangeiros (BACHA, 2014; 
BAUMANN, 2013b; O' NEIL, 2013). Parte da argumentação é a de que o Brasil se acomodou ao período de superávits comerciais de balanço de pagamentos e não soube se preparar para o momento em que se exaurisse o espaço fiscal e os investimentos de longo prazo para o aumento da competitividade industrial.

O processo internacional de fragmentação e dispersão da produção que deu origem às cadeias globais e regionais de valor tornou-se referência como novo padrão de comércio internacional e, dadas as oportunidades de ganhos de eficiência e produtividade, tornou mais custosas as visões de mundo demasiadamente centradas no mercado doméstico, na substituição de importações e na promoção governamental de setores chamados "campeões nacionais". A economia brasileira está à margem desse novo processo produtivo, o que se explica, em parte, pelas dimensões do país e por aspectos históricos e estruturais, mas, também, por políticas domésticas e industriais de cunho (neo) desenvolvimentista.

A tendência é de que os produtos provenientes das cadeias globais de valor sejam de melhor qualidade e mais competitivos do que aqueles produzidos em uma cadeia verticalmente localizada em um único território nacional, dado o melhor aproveitamento dos menores custos de produção transfronteiriça e fruição das vantagens comparativas entre os países (OCDE; WTO; UNCTAD, 2013).

Dentre as três tradicionais formas de abertura comercial, unilateral, preferencial e multilateral ${ }^{7}$, esta última é a que traz maiores ganhos no agregado e reduz os riscos de desvio de comércio ao reunir mais países com o compromisso de reduções de barreiras tarifárias e outras distorções ao comércio. Entretanto, o grande número de nações reunidas nas mesas de negociações na governança do comércio global é justamente uma das razões das dificuldades atravessadas para o alcance de um consenso na OMC, o que fez com que a liberalização multilateral na Rodada Doha, iniciada em 2001, se estagnasse, com impactos deletérios para o Brasil, que apostou fortemente na sua conclusão.

Com a crise de 2008/2009 e a estagnação da Rodada Doha, os países passaram a buscar as vias preferenciais para expandir o seu comércio, fonte de eficiência econômica, emprego e renda. Houve uma proliferação de acordos comerciais bilaterais,

\footnotetext{
7 A liberalização unilateral é realizada sem a consideração do critério de reciprocidade; a abertura preferencial é realizada entre um grupo de dois ou mais países, com permissão expressa aos Estadosmembros da OMC, inserida no art. XXIV do GATT; já a liberalização multilateral tem como fórum de negociações a OMC, com formulação de regras e normas de escopo mais global que passam a valer para todos os seus Estados-membros, mesmo que com prazos distintos.
} 
dos quais o Brasil e o Mercosul mantiveram-se relativamente afastados, uma vez que assinaram apenas três acordos desde 2003, de escopo limitado.

\section{Estrutura da Dissertação}

Esta dissertação divide-se em cinco partes, além desta introdução. Primeiramente, descreve-se e analisa-se as principais mudanças estruturais na economia global do século XXI que contribuíram para o aumento da interdependência econômica global e ensejaram a ascensão dos países emergentes. O processo de fragmentação da produção e sua dispersão geográfica que deu origem às cadeias globais e regionais de valor aumentaram os custos de adoção de políticas altamente soberanistas e autonomistas na política internacional contemporânea. Trata-se esse primeiro capítulo da configuração internacional na qual os Estados devem ter basear-se para a consecução de interesses nacionais neste princípio do século XXI.

No segundo capítulo, descreve-se o cenário internacional amplamente favorável à economia brasileira de 2004 a meados de 2011, o qual beneficiou o Brasil com grandes superávits comerciais e no balanço de pagamentos. Essa conjuntura internacional foi atípica em relação às décadas anteriores, e foi diante dela que o Brasil recebeu grande destaque como potência emergente. A crise internacional de 2008/2009 reavivou um pensamento interventor do estado na atividade econômica do Brasil, e houve uma espécie de "efeito colateral" desse cenário para a pauta exportadora do País, que passou por um processo de primarização, reforçada tanto pela política de incentivo ao consumo de massa e proteção do mercado interno, quanto por uma certa acomodação ao influxos decorrentes da venda de commodities.

No terceiro capítulo, analisa-se os caminhos percorridos pelo Mercosul na primeira década e meia do século XXI, sob a perspectiva do regionalismo "póshegemômico" e dos dilemas enfrentados pelo atrelamento do Brasil ao bloco. Trata-se esse capítulo de uma combinação de eventos exógenos com opções de política brasileira. O destaque é dado aos caminhos seguidos pelo Mercosul que limitariam a formação de uma cadeia de valor regional futura, com base na teorias de integração produtiva e experiências internacionais de sucesso. Destaca-se que o relativo afastamento do eixo econômico como alicerce da integração entre os países impõe 
maiores barreiras à consolidação de um próspero processo de integração comercial e produtiva similar ao que foi realizado pelos países do Leste Asiático.

Após a descrição e análise das transformações estruturais e conjunturais na economia global, assim como do processo de integração regional sul-americano perante essas mudanças, no quarto capítulo avalia-se a política comercial externa brasileira do período em destaque (2003-2014). Adota-se uma perspectiva comparada do Brasil com demais países considerados emergentes, a fim de se obter uma avaliação do grau de singularidade do País em relação aos semelhantes ou comparáveis. O destaque é dado à relativa baixa participação da corrente comercial comércio sobre o PIB brasileiro; à distorcida estrutura de proteção tarifária no Brasil; o teor de política anticíclica que caracterizou a política industrial brasileira; à baixa taxa de investimento na economia, a qual poderia vir a ser um diferencial de competitividade; à participação nas cadeias globais de valor; e ao isolamento do País das negociações dos mega-acordos comerciais, TTIP e TPP, bem como seus potenciais impactos para o país.

Por fim, têm-se as considerações finais a pesquisa e recomendações de políticas para o Brasil frente às novas realidades do mundo interdependente. 


\section{CAPÍTULO 1 - A NOVA ECONOMIA POLÍTICA INTERNACIONAL, A INTERDEPENDÊNCIA CRESCENTE E AS CADEIAS GLOBAIS DE VALOR}

Este capítulo tem por objetivo descrever a configuração internacional de mudanças na economia global das últimas décadas, com especial atenção ao processo de fragmentação e dispersão da produção internacional e a resultante formação das Cadeias Globais de Valor como parte dos novos padrões de comércio internacional. A inserção dos países emergentes no contexto da globalização contemporânea, bem como as reformas realizadas pró-mercado em grande parte do mundo anteriormente conhecido como "subdesenvolvido" ou "em desenvolvimento" foram fundamentais para o aumento da integração econômica internacional.

O enfoque é direcionado ao contexto da globalização contemporânea e às implicações teóricas e cognitivas das CGV na política internacional contemporânea. Argumenta-se que há um aumento da interdependência econômica em âmbito global, o qual aumenta os custos de oportunidade de decisões unilaterais demasiadamente desenvolvimentistas, bem como os custos de permanecer à margem das novas dinâmicas da globalização comercial e produtiva.

\subsection{A Nova Economia Política Internacional: Principais Questionamentos e Mudanças}

Esta dissertação insere-se dentro do subcampo da Economia Política Internacional do campo das Relações Internacionais, mais especificamente, no que tange às interações entre a política doméstica e a economia política internacional ${ }^{8}$. Portanto, faz-se necessário discorrer brevemente sobre os estudos do campo e suas contribuições teóricas e analíticas para a construção do argumento.

Os estudos realizados dentro do subcampo hoje conhecido como Economia Política Internacional - EPI - são relativamente recentes, remontando à década de 1970. O momento era propício para explorar e buscar relações causais para os problemas e eventos conjunturais e estruturais econômicos marcantes que moldariam o futuro das relações internacionais contemporâneas: a crise de conversibilidade do dólar americano

\footnotetext{
${ }^{8}$ Assim como definem Katzenstein, Keohane e Krasner (1998), esta dissertação refere-se ao conceito de "economia política internacional" como as "conexões do mundo real entre política e economia" e o termo "EPI", como o "subcampo de trabalho" (p.645).
} 
e o abandono do sistema de Bretton Woods em 1971; o embargo do setor petrolífero, organizado pela OPEP; o segundo choque do Petróleo; a relação do aumento da taxa de juros dos EUA e a dívida externa dos países latino-americanos; o ingresso de países da "periferia europeia" - Grécia, Espanha e Portugal na, até então, Comunidade Europeia; e as reformas econômicas de mercado realizadas por Deng Xiaoping na China em 1978, são alguns exemplos desses eventos. Antes desses e outros eventos, os temas econômicos eram tratados como low politics pelos estudiosos de política internacional, já que a disputa geopolítica entre as superpotências americana e soviética, bem como o temor de uma guerra nuclear, dominavam a agenda de pesquisa das relações internacionais. Do mesmo modo, era comum que os estudos econômicos negligenciassem o papel da política.

No início, o subcampo da EPI era difuso e não havia métodos e ferramentas próprios ou razoavelmente aceitos, possuindo características epistemológicas muito semelhantes à política comparada. Contudo, também há limites para o estudo comparado, embora seja uma boa fonte de inferências causais. Conforme afirmam Katzenstein, Keohane e Krasner (1998, p. 648), "variações nas estruturas domésticas (definidas em termos de estrutura social, bem como de alinhamentos de grupos e partidos) conduziria a diferentes respostas nacionais e corporativas para as mesmas pressões externas e oportunidades" (tradução nossa). Diante disso, ressalta-se a importância dos estudos de caso e revelam-se os limites da generalização.

Há atualmente dois questionamentos recorrentes no subcampo da EPI, conforme relata Lake (2009). O primeiro diz respeito a quando, como e por que países se abrem à economia internacional. Nesta, a variável dependente é a abertura ou liberalização e a variável independente ou causal é a política. A outra pergunta diz respeito a como a integração na economia internacional afeta os interesses de diferentes atores - tais como indivíduos, grupos, países - e, por sua vez, as políticas nacionais. Nesta segunda, a política passa a ser a variável dependente e o lugar do ator na economia internacional, em outras palavras, como está situado nesta, é a variável independente (LAKE, 2009, p. 221). Ambos podem ser questionamentos convergentes e que auxiliam a direcionar esta pesquisa centrada na interação entre a política doméstica e a política internacional, também com o intuito de vincular uma agenda teórica a um puzzle empírico.

Ademais das questões de método e questões centrais da EPI, Keohane sugere que o subcampo necessita de uma atualização em sua agenda de pesquisa, em especial no que concerne a uma série de mudanças em curso na economia e política internacional 
contemporânea (KEOHANE, 2009). Para o autor, cinco dessas grandes questões sobre as mudanças mereceriam maior destaque entre os acadêmicos da área:

1. Uma maior atenção aos países emergentes, bem como a diferentes gradações de desenvolvimento que não unicamente a divisão dual - países desenvolvidos e em desenvolvimento, e a maneira como estes alteram as antigas relações de "interdependência assimétrica". Segundo o autor, "For the first time in history, genuine economic development is taking place for much of the world's population" (KEOHANE, 2009, p. 40);

2. A centralidade da China na economia e na política internacional que, "has become a huge player in international trade and finance, as the manufacturing center of the world for a huge number of products in ordinary life" (p. 41);

3. A alta volatilidade nos mercados financeiros e de energia, que se tornaram extremos neste século;

4. A importância crescente de atores não estatais como as corporações globais, que atuam em forma de redes e demandam atualização dos regimes globais existentes: "Truly global actors are now important in world politics" (p. 41); e,

5. O impacto das tecnologias $e$ inovações, que se tornaram a base para as comunicações globais e que facilitam a ação coletiva em escala global.

Essas cinco grandes questões permeiam em alguma medida este estudo, pois esses fenômenos impactaram consideravelmente os processos de fragmentação e dispersão da produção e fomentam a agenda das negociações dos Mega Acordos TransPacífico e Transatlântico e, adicionalmente, contribuem para a análise dos determinantes políticos brasileiros para a baixa inserção nas grandes mudanças da economia global no século XXI, conforme será descrito mais adiante.

Além de destacar essas grandes mudanças, esta dissertação tem como premissas alguns importantes resultados de pesquisas do campo da Economia Política Internacional, oriundas de pesquisas de alto reconhecimento internacional sobre o impacto político, econômico e social da interdependência pela qual os países até então referidos como desenvolvidos e em desenvolvimento estavam e continuam atrelados.

Há algumas premissas nas quais o trabalho é baseado, com as quais claramente concordamos e que têm sido corroboradas por estudos sobre a globalização e conexões da política doméstica com a política internacional, fundamentais para a construção do argumento: 
1. "Mudanças no ambiente econômico internacional afetam as preferências políticas e comportamento de grupos domésticos e, assim, têm um impacto na formulação de políticas nacionais e políticas econômicas externas" (FRIEDEN; MARTIN, 2003, p. 122, tradução nossa). Beneficiado por um cenário externo excepcionalmente favorável, a partir de 2003, o Brasil optou por exercer no plano da política externa o seu maior poder de barganha na tentativa de liderança dos países do Sul, e de seu projeto de integração sul-americana, mas não realizou reformas importantes a partir de 2006, como a liberalização comercial, ou assinaturas de acordos comerciais relevantes, quando o momento era propício.

2. Compreendida como a evolução da integração econômica internacional, a globalização altera as opções disponíveis para os governos nacionais, que, por sua vez, afeta a política nacional (e, com isso, resultados externos) (FRIEDEN; MARTIN, 2003, p. 122, tradução nossa).

3. É importante ser competitivo em termos internacionais para a sustentabilidade da produção nacional, evidenciado pela experiência dos países do Leste Asiático (AZEVEDO, 2014; BAUMANN, 2013a; BHAGWATI; PANAGARIYA, 2013; THORSTENSEN et al., 2014).

\subsection{As Grandes Mudanças na Economia Global}

\section{A Ascensão Econômica da Ásia- Pacífico}

A ascensão econômica dos países da Ásia-Pacífico é um processo em grande parte iniciado na década de 1970/80 pelos chamados, à época, de Newly Industrialized Countries (NICs) do leste asiático: Coreia do Sul, Hong Kong, Taiwan e Cingapura, países que abriram a conta de capital nacional, promoveram programas de amplo investimento na indústria e no capital humano, bem como incentivos ao comércio exterior. Devido ao seu alto crescimento, esses países também ficariam conhecidos como "Tigres Asiáticos". Demais países seguiram, em alguma medida, o padrão de rápida industrialização no continente asiático, como China, Indonésia, Malásia, Tailândia e Vietnã nas décadas de 1990/2000. Esse processo pode ter se acentuado nos últimos anos, principalmente após a crise de 2008, iniciada com a quebra do Lehman 
Brothers (NYE, 2011). De fato, segundo a National Intelligence Unit (2009), houve uma intensificação da transição de poder econômico do centro - EUA e União Europeia - a países asiáticos. De acordo com o relatório (NIU, 2009, p. 40): “em termos de tamanho, velocidade e fluxo direcional, a transferência da riqueza mundial e poder econômico agora em curso - basicamente do Ocidente para o Oriente - é sem precedentes na História moderna”. Essa transição deve-se em grande parte ao aumento do poderio da China, a "factory of the world", e da Índia, "world's back office", que possuem peso crescente sobre a produção e demanda globais (NEILSON; PRITCHARD; YEUNG, 2014).

No mesmo sentido, Kissinger afirma que "the center of gravity of world affairs is shifting from the Atlantic... to the Pacific (2005)." Tal ascensão é resultado de estratégias de desenvolvimento unidas aos mercados globais realizadas pelos países do leste asiático, assim como os custos mais baixos de produção, o que deslocou o lócus da manufatura e serviços industriais para o continente asiático e, consequentemente, incrementou seu crescimento e recursos de poder (FRIEDEN, 2008; CIA, 2009).

Segundo Gilpin (1987, p. 398), a região da Ásia-Pacífico adotou o esquema de regionalismo para o fomento do crescimento econômico doméstico, a fim de obter complementaridades econômicas, aliada a uma abertura das economias nacionais (BAUMANN, 2013a). Nesse sentido, não se tratavam de estratégias de desenvolvimento puramente nacionais. Sato (2012) relata que uma das principais estratégias para o grande crescimento dos Tigres Asiáticos foi baseada na intensificação das relações comerciais, financeiras e produtivas com os países desenvolvidos, em especial com Japão e Estados Unidos nos anos 1980. Aqueles países assumiram um papel periférico na ordem econômica internacional, se beneficiando dos ciclos econômicos da globalização e dos fluxos de investimento (SATO, 2012).

Em 2009, como recomendação para o período de recuperação econômica póscrise de 2008, a Comissão Econômica para a América Latina e o Caribe (CEPAL) sugeria aos países latino-americanos uma aliança estratégica com a região da ÁsiaPacífico, em razão da dinâmica econômica que a região representa, a fim de diversificar os riscos que se apresentam às economias da América Latina:

El rol protagónico de Asia-Pacífico en la economía mundial sugiere que América Latina debería tender a una alianza estratégica con esa región. Dados los inminentes riesgos que siguen acechando a la economía mundial y la aparición de una nueva geografía de esa economía, cada vez más centrada en torno a Asia-Pacífico, los países del Arco del Pacífico Latinoamericano deberían redoblar sus esfuerzos para identificar y beneficiarse de las posibles 
complementariedades con Asia-Pacífico. El paso inmediato es avanzar en la diversificación de las exportaciones, idealmente a través de la gestación de alianzas empresariales birregionales (CEPAL, 2009, p. 111).

Cabe advertir que a ascensão da Ásia-Pacífico como região proeminente na economia internacional - em boa parte ensejada por China e Tigres Asiáticos em termos de participação em cadeias produtivas globais e na logística internacional ${ }^{9}$ - não implica necessariamente na redução do papel preponderante dos Estados Unidos na economia internacional. Isso porque, não somente em razão da recuperação da atividade econômica pós-crise 2008/2009 (a exemplo da valorização do dólar dos mercados internacionais em 2014 e 2015), mas simplesmente por questão geográfica, já que também possui vantagens com o comércio com a região do Pacífico em virtude de sua larga costa oeste, banhada pelo maior oceano do planeta. O país inclusive está liderando a negociação dos dois grandes acordos que se inserem nos novos regionalismos e um deles é justamente direcionado às economias da região do Pacífico, a parceria TransPacific Partnership (TPP).

Em termos de implicações teóricas, o crescimento dos países asiáticos é uma evidência em contrário a preceitos da teoria da dependência dos anos 1970. Ao destacar o crescimento desigual e ao justificar o fato de que países não desenvolvidos permaneceriam nessas condições por estarem inseridos no contexto da economia internacional - esta tendencialmente negativa e exploratória contra esses países -, seus proponentes destacam que haveria aumento da dependência dos países da periferia em relação aos países centrais. O que se verificou, em especial com Coreia do Sul, Taiwan, Hong Kong e Cingapura, é que esses países aumentaram o seu grau de integração aos fluxos econômicos internacionais, com o Estado adotado de forma mais eficiente um papel central na participação desse processo, a partir dos anos 1980, integrando-se em ritmo maior, inclusive, do que nações europeias e Estados Unidos. Os quatro países souberam atuar dentro do contexto da globalização contemporânea e elevaram de forma constante o grau de interdependência com os países considerados centrais, o que impulsionou as inovações tecnológicas, o aumento da produtividade e o seu crescimento (FRIEDEN, 2006; LAKE, 2009).

\footnotetext{
${ }^{9}$ Exemplo disso são os portos de Cingapura e de Xangai, que continuamente dividem o posto de maior porto do mundo.
} 


\section{A Evolução do Comércio Internacional e as Economias de Escala}

A teoria do comércio internacional convencional trata da explicação do fluxo de bens entre países em termos de vantagens comparativas como reflexo dos custos de oportunidade e tecnologia (David Ricardo), de produtividade (Adam Smith), da diferença na dotação de fatores de produção (Heckscher-Ohlin), e intensidade no uso desses fatores (Teoria dos Fatores específicos). No que concerne a esses modelos, o comércio internacional seria mais intenso entre economias díspares, as quais apresentariam retornos constantes de escala. Pressupõe-se do modelo teórico de comércio de Heckscher-Ohlin que não haveria "espaço" para o comércio entre economias semelhantes, além de concentrar-se na troca de bens finais. Krugman (1979) e Helpman (1981), dentre outros, formularam novos modelos de comércio internacional nos quais ressaltaram o papel das economias de escala como incentivos impulsionadores das trocas comerciais. Para o primeiro autor, as economias de escala fornecem uma alternativa às diferenças na dotação de fatores e tecnologia como explicação da especialização e o comércio internacional (KRUGMAN, 1990, p.11). Além disso, como destaca Almeida, os padrões de especialização comercial não seriam necessariamente "derivados das vantagens comparativas, mas (também) de fatores arbitrários, tais como: eventos históricos, efeito eventual de processos cumulativos, mudanças tecnológicas e choques econômicos temporários" (ALMEIDA, 2013a, p.60).

De fato, a maior parte do comércio internacional concentra-se no eixo NorteNorte, entre economias industrializadas e, em parte, semelhantes, com geração de um comércio inter e intraindústria (FEENSTRA, 1998). Ao contrário do setor agrícola, o setor industrial raramente possui substitutos perfeitos. A integração econômica na União Europeia, por exemplo, apresenta um comércio intenso interindustrial com rendimentos de escala crescentes. Balassa (1967) e Kravis (1971) argumentam que as economias de escala desempenharam um papel crucial na explicação do crescimento no pós-guerra de países industrializados (apud KRUGMAN, 1998). Além disso, ao longo do tempo, os países industriais foram adquirindo certas semelhanças em níveis de tecnologia, em disponibilidade de capital e de qualificação de trabalhadores (FEENSTRA, 1998).

O comércio intraindústria passou a desempenhar um enorme papel no comércio mundial pelas trocas de produtos similares entre países similares em especial na década de 1980, quando esse tipo de comércio era um fenômeno relativamente novo, a exemplo 
do comércio bilateral entre os Estados Unidos e Canadá. Empresas similares também se especializavam em variedades horizontalmente distintas, gerando um comércio intraindústria entre os países, com ganhos de escala de produção. Muitas vezes não há vantagem comparativa em uma indústria e, portanto, grande parte do comércio internacional toma a forma de intercâmbio em ambos os sentidos dentro dos setores industriais (KRUGMAN, 1998; FEENSTRA, 1998).

Contudo, para tirar vantagem das economias de escala, cada um dos países deve concentrar-se em produzir somente um número limitado de bens. Se cada país produzir somente alguns bens, cada bem poderá ser produzido em uma escala maior. Onde há economias de escala, dobrar os insumos em um dado setor mais do que dobrará sua produção (BAUMANN; GONÇALVES; CANUTO, 2004; KRUGMAN; OBSTFELD, 2010). Quando há retornos crescentes, as empresas grandes costumam levar vantagem sobre as pequenas, de modo que os mercados tendem a serem dominados por uma só empresa (monopólio) ou, mais frequentemente, por poucas delas (oligopólio). Dessa forma, quando os retornos crescentes passam a fazer parte do comércio, geralmente os mercados começam a refletir uma concorrência imperfeita (BAUMANN; GONÇALVES; CANUTO, 2004, p.87). Nesse sentido, caberia ao Estado regular e evitar abusos e maiores distorções à troca justa.

Há de se destacar também uma noção de especialização da teoria tradicional de comércio e sua relação com os novos padrões de intercâmbio comercial. A abertura comercial implica em maior concorrência aos setores domésticos, sobretudo os menos competitivos incapazes de competir sem proteção contínua e de longo prazo. Por outro lado, os segmentos mais competitivos poderão ser ampliados, com um aumento da demanda por mão de obra, elevando níveis de emprego e renda, além de angariar benefícios da economia de escala. $\mathrm{O}$ mesmo argumento também pode ser relacionado às dinâmicas das cadeias de valor (MANKIW, 2013; CANUTO, 2014a, p. 45).

Há também um efeito retroalimentado da expansão das exportações e das importações. $\mathrm{O}$ aumento das exportações eleva o número de divisas internacionais, que, por sua vez, poderá fomentar importações, o que pode aumentar o bem estar nacional. O aumento das importações, além de ajudar a reduzir pressões inflacionárias, pode ajudar a elevar o nível da competitividade das exportações de um país em termos de preço e qualidade, ao incorporar bens intermediários importados nas exportações finais. 


\section{A Globalização Contemporânea e o Surgimento das Cadeias Globais de Valor}

No final do século XIX e início do século XX, a globalização parecia um processo de ritmo constante e crescente, quando possuía tendências similares ao fenômeno da globalização do século XXI. O período, também conhecido como Belle Époque (1870-1914), ficou marcado por uma grande transformação cultural e social, bem como pelo aumento dos fluxos transcontinentais e por grandes inovações que mudariam radicalmente as relações humanas, como o telefone, o automóvel e o avião (FRIEDEN, 2008; SATO, 2012).

Entretanto, eventos de grande magnitude histórica viriam a desafiar a integração econômica global. A crise de superprodução de 1929, conhecida como a Grande Depressão, provocou desemprego em massa e aumentou a descrença nos mercados por parte dos governantes e das sociedades, que passaram a voltar-se mais aos assuntos internos e a implantar ideais intervencionistas, comuns em momentos pós-crise. As duas grandes guerras mundiais viriam por ensejar fortemente o erguimento de barreiras políticas e econômicas, com o aumento da imposição nacionalista e do protecionismo contra empresas e produtos estrangeiros, provocando uma grande regressão da integração econômica global conquistada. De acordo com estudo do Banco Mundial, pelo fim dos anos 1940, o comércio internacional proporcional à renda mundial estava próximo aos níveis de 1870, "protectionism had erased 80 years of progress" (COLLIER; DOLLAR, 2002, p. 4). As práticas robustas nacional-protecionistas haviam reduzido o crescimento, com um aumento dos níveis de pobreza e desigualdade mundial.

O período compreendido de 1950 a 1980 ficou marcado pela segunda onda da globalização, por sua vez, ainda focado na integração entre países avançados (COLLIER; DOLLAR, 2002). A reconstrução da Europa e do Japão no pós-guerra, em boa parte resultante de financiamentos e empréstimos concedidos por meio do Plano Marshall $^{10}$, seria guiada por um viés de promoção de exportações, que elevaram enormemente a produção industrial dos países aliados dos Estados Unidos (FRIEDEN, 2008, p. 291). O Sistema de Bretton Woods, com seu trio de organizações - econômica, Banco Mundial; financeira, Fundo Monetário Internacional; e comercial, o Acordo

\footnotetext{
${ }^{10}$ O Plano Marshall foi um plano de recuperação econômica promovido pelos EUA, e liderado por seu secretário de Estado George Marshall, em 1947, que visava não somente à retomada do crescimento econômico e social dos aliados norte-americanos, mas também à contenção do comunismo, a ameaça considerada vital para os interesses delineados no contexto da Guerra Fria segundo a política externa norte-americana (BUZAN, 2011; FRIEDEN, 2008).
} 
Geral de Tarifas e Comércio (GATT) (sendo esta uma organização de fato, mas não de direito) - viria a elevar o crescimento econômico, reduzir taxas de desemprego e estabilizar preços, bem como ampliar a difusão tecnológica, retomando níveis de integração internacional anteriores (FRIEDEN, 2008).

Esse período foi central para o início do processo de fragmentação e dispersão da produção que se concentraria nas três áreas geográficas conhecidas como as grandes "fábricas do globo": Europa, América do Norte e Leste Asiático. Isso foi resultado dos esforços promovidos, à época, por Estados Unidos, Japão e Europa Ocidental na restauração das relações comerciais pela liberalização multilateral no âmbito do GATT. Importante destacar que os países desenvolvidos passaram a estar muito mais integrados entre si do que os países em desenvolvimento, pois as economias destes ainda estavam (em maior medida na América Latina) fortemente atreladas às exportações de commodities e também permaneciam relativamente isolados dos fluxos de capitais internacionais. Essa discrepância de integração entre grupos de países fez com que aumentasse a desigualdade entre $\mathrm{o}$ mundo desenvolvido e $\mathrm{o}$ até então em desenvolvimento, na medida em que o crescimento dos países centrais era maior do que o crescimento dos países em desenvolvimento e pobres, estes, com menor integração entre si e maior proteção (inward economies) (COLLIER; DOLLAR, 2002).

A evolução das exportações mundiais de 1950 até os dias atuais ilustra esse aumento extraordinário do comércio internacional e, por conseguinte, do grau de interdependência econômica entre os países. Nota-se pelo gráfico abaixo que o comércio internacional veio a crescer de forma quase que contínua a partir da década de 1970 e que o mesmo estava longe de alcançar o valor de 1trilhão de dólares nas décadas de 1950 e 1960. O mencionado processo de liberalização no âmbito do Gatt e recuperação econômica da Europa e do Japão foram indispensáveis para o aumento dos fluxos comerciais nos anos 1970 e na década seguinte. 
Figura 1 - Evolução das exportações mundiais de 1950 a 2013

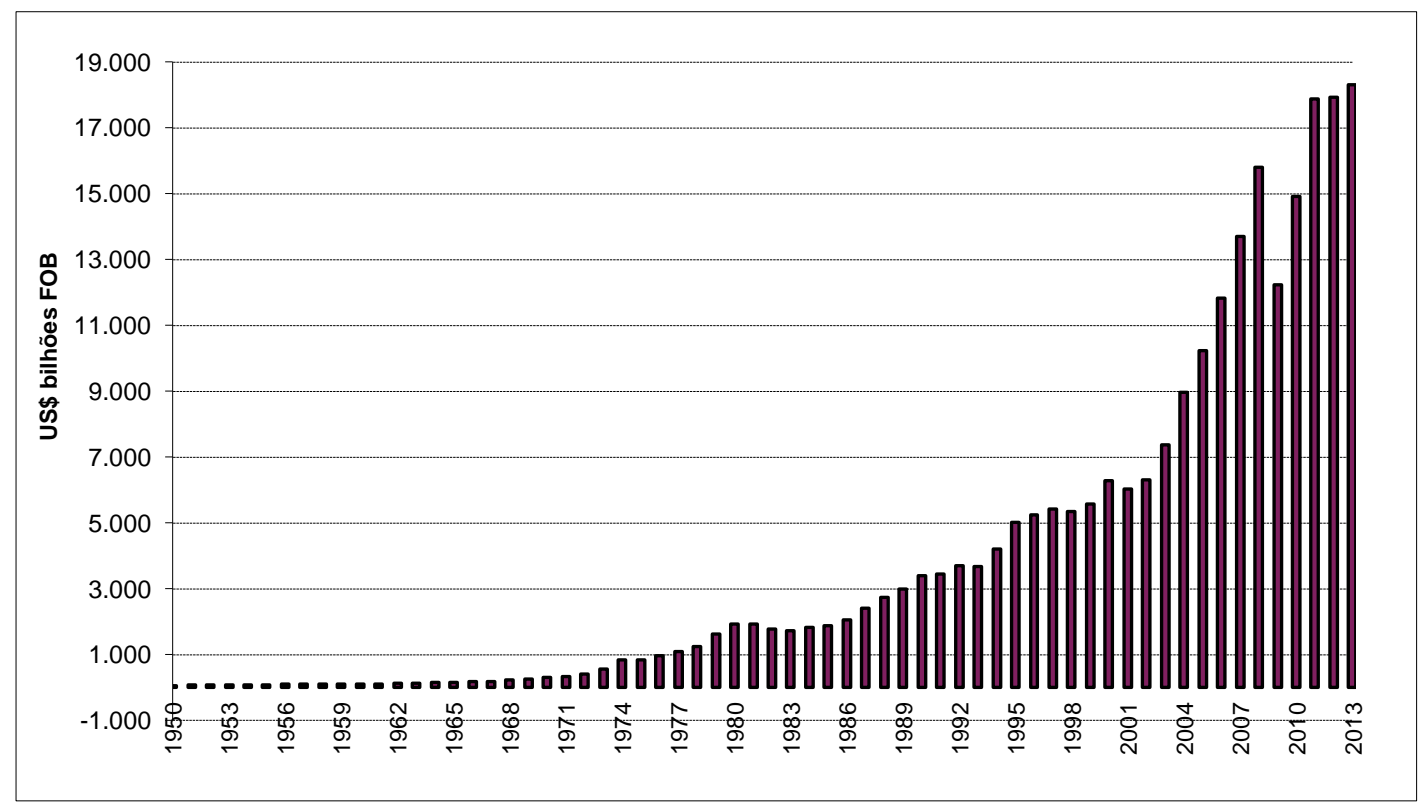

Fonte: MDIC/Secex.

O ingresso mais incisivo do mundo em desenvolvimento no fenômeno da globalização ${ }^{11}$ viria a ocorrer em meados da década de 1980, impulsionando uma nova e terceira onda globalizante. Eventos exógenos ajudaram nesse processo, como os rápidos avanços tecnológicos no transporte e comunicações (dentre os quais, os avanços nos computadores e no telefone móvel), facilitando a liberalização de fluxos comerciais em nível transcontinental. Todavia, essa integração só pôde ser impulsionada à época por opção política dos grandes países em desenvolvimento em adotar reformas macroeconômicas (neo) liberais para ganhos de produtividade e redução dos gastos públicos excessivamente elevados em prol de equilíbrios fiscais (ALMEIDA, 2013a; VIOLA; FRANCHINI; RIBEIRO, 2013) ${ }^{12}$. Para isso, era necessária a adoção de melhorias no ambiente doméstico para a atração de investimentos domésticos e estrangeiros e promoção da abertura comercial. Assim, pela primeira vez, os países de renda média e baixa eram capazes de fomentar o potencial da abundância de mão de

\footnotetext{
${ }^{11}$ De acordo com Held e McGrew (2003, p.4), "a globalização denota a expansão de escala, a magnitude crescente, a aceleração e o impacto aprofundado de fluxos inter-regionais e padrões de interação social", referindo-se a uma "mudança ou transformação na escala da organização social humana que liga distantes comunidades e expande o alcance das relações de poder ao redor das maiores regiões do mundo e continentes".

${ }^{12}$ A revolução macroeconômica de 1989, também conhecida como conjunto de reformas (neo)liberais, levou ao aumento da produção capitalista. O comércio internacional cresceu a taxas maiores do que o próprio PIB mundial. Com isso, houve também um aumento considerável da produção e da informação, o que ajudou a consolidar a hegemonia das democracias de mercado. Na década de 1990, houve também um avanço dos mercados sobre os Estados de forma contínua até a crise de 2008. Após a crise, houve um avanço dos Estados sobre os mercados no sistema internacional, mas com menor intensidade (VIOLA; LEIS, 2007; VIOLA; FRANCHINI; RIBEIRO, 2013).
} 
obra para adoção de reformas internas, via integração aos mercados globais de serviços e bens manufaturados, o que foi o caso do Brasil, China, Hungria, Índia e México (FRIEDEN, 2008; SATO, 2012; COLLIER; DOLLAR, 2002).

O crescimento da maior parte do globo, em boa parte derivado da abertura de mercados até então bloqueados - como China, Índia, Leste Asiático e, em menor medida, a Rússia - da liberalização financeira e comercial e da melhoria da regulamentação governamental, permitiu uma maior "distribuição de renda" em termos globais, devido ao aumento do influxo do capital estrangeiro para os mercados emergentes e em desenvolvimento (BALDWIN, 2011; FRIEDMAN, 2007). A inserção dos emergentes no mercado internacional ajudou a praticamente triplicar o comércio internacional de 2001 a 2013, conforme a figura 2.

O aumento de fluxo de capital estrangeiro só foi possível, cabe destacar, a partir da mudança no modelo de gestão das empresas transnacionais quanto à busca de investimentos fora do seu país de origem - possibilitada, mais uma vez, pela revolução tecnológica e de comunicações -, o que permitiu a maior integração dos emergentes ao ciclo de atividades das nações desenvolvidas. A ideia de "cadeia de comando", atrelada à atividade "verticalizada" e nacionalizada de muitas empresas, tornou-se em parte obsoleta, sendo mais atrativa para os investidores e produtores nacionais e estrangeiros a "horizontalização" do ciclo de negócios, no qual a ideia de "conexões, fluxos e colaborações" predomina (FRIEDMAN, 2007), em busca do aproveitamento das vantagens comparativas e competitivas ao redor do globo.

As reformas de mercado chinesas, iniciadas por Deng Xiaoping em 1978, também chamadas de "reform and opening up" pelo professor David Daoki $\mathrm{Li}^{13}$, seriam um marco para a história contemporânea. A China possui tal centralidade na economia mundial, de forma a ser considerada uma "fábrica global" (KEOHANE, 2009), sendo a maior detentora de títulos americanos e de grande poder de mercado como "autoridade" na compra de bens agrícolas (isto é, tem a capacidade de determinar preços internacionais pela demanda), o que, inclusive, contribuiu para a expansão de commodities de boa parte dos países latino-americanos, com destaque ao Brasil, potência global do agronegócio. A China, junto com Japão e Coreia do Sul, é um dos três big bosses (grandes chefes ou líderes) da produção manufatureira e até tecnológica

\footnotetext{
${ }^{13} \mathrm{Nas}$ palavras do professor Li, "reform implies gradual improvements in our institutions, whether they are political or economic. Opening up refers to learning whatever is best in the West" (apud GRIFFITHS, 2011, p. 52).
} 
do Leste Asiático, na concentração da cadeia de valor regional (BALDWIN, 2012). Há quem diga que essa maior proeminência chinesa na economia internacional em relação ao século XX é apenas um retorno à tendência histórica, como argumenta o historiador Nial Fergunson que "(...) the 19th and 20th centuries were exceptions. Eighteen of the last twenty centuries saw China as, by some margin, the largest economy in the world." (GRIFFITHS, 2011, p. 14).

O gráfico abaixo indica o crescimento real do PIB mundial, das economias avançadas e das economias emergentes de 1980 a 2014. Nota-se que a partir de 1983 as taxas médias de crescimento das economias avançadas e emergentes eram bem similares até o final da década de 1980. A partir da década de 1990, houve um declínio na taxa dos países desenvolvidos, e os emergentes passaram a crescer a maiores taxas reais. Após as crises cambiais nas economias emergentes, mais uma vez as taxas de crescimento real dos dois grupos de países voltariam a ser similares. No entanto, o século XXI apresentaria duas grandes alterações: (1) as economias emergentes passaram a crescer muito mais do que as economias avançadas, com reforço do crescimento de dois dígitos apresentado pela economia chinesa e do baixo crescimento do mundo desenvolvido; (2) e as oscilações nas taxas de crescimento apresentariam grande simetria entre emergentes e desenvolvidos, o que por si só pode ser uma ilustração do maior interdependência econômica global verificada em relação às décadas anteriores.

Figura 2 - Crescimento percentual real do PIB mundial, economias avançadas e economias emergentes (variação percentual anual)

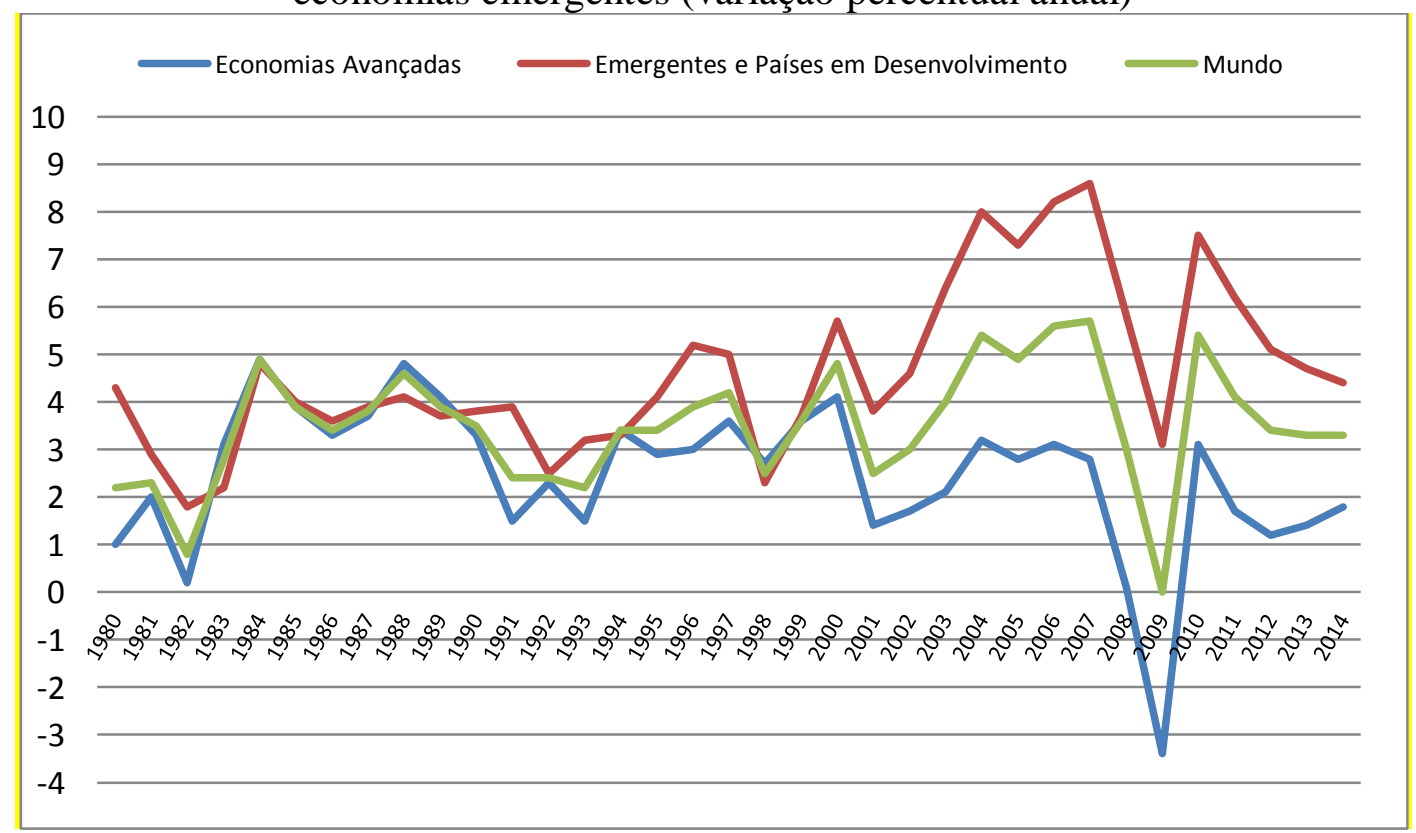

Fonte: elaboração própria com base nos dados do FMI (2015). 
Como descreve Spence (2010, p. 13), os países de desenvolvimento tardio há muito deixaram de ser referenciados como "atrasados" ou "subdesenvolvidos". Durante a Guerra Fria, os países não desenvolvidos que não estivessem na órbita do "segundo mundo" - de acordo com a órbita de influência da União Soviética - faziam parte do até então "terceiro mundo", conceito criado por geógrafos, para diferenciá-los do próprio "primeiro mundo" capitalista avançado. A teoria dos "três mundos" estava atrelada a um contexto específico de disputas geopolíticas entre as superpotências EUA e URSS, que dominavam a agenda internacional, o que, por sua vez, ocultava temas voltados ao desenvolvimento e à cooperação. Além disso, a economia internacional não era tão globalizada e interdependente como é a do século XXI (ela restringia-se ao primeiro mundo e às partes mais dinâmicas do terceiro mundo, já que o segundo mundo formava um sistema aparte, bastante desconectado) e muitos países ainda lutavam por sua independência e autonomia política.

Devido ao reconhecimento de que o baixo nível de desenvolvimento apresentado pela maior parte do globo poderia não ser uma condição permanente, utilizou-se, em seguida, o termo "menos desenvolvido" (SPENCE, 2010). Posteriormente, com o avanço do processo de globalização e intensificação dos fluxos financeiros, comerciais, migratórios e de informação, via-se que a noção contemporânea de "país em desenvolvimento" era mais adequada dada a realidade de reversão do processo de subdesenvolvimento, como denotado no caso dos Newly Industrialized Countries (NICS). O termo mais recente "economias ou mercados emergentes" foi cunhado pelo economista Antoine van Agtmael, que trabalhava em agências de avaliação de risco, e denota um sentido mais intenso quanto à evolução das economias nacionais que diminuem sua distância ao longo do tempo em relação aos países desenvolvidos, dando a entender que as mudanças esperadas já estavam acontecendo. Para Spence, a evolução conceitual para designar os países não pertencentes ao mundo desenvolvido representa uma consciência crescente em relação ao desenvolvimento dessas economias, que estavam "em algum tipo de transição, embora demorada (da ordem de um século), para se tornarem locais de renda elevada" (SPENCE, 2010, p.13) ${ }^{14}$.

\footnotetext{
${ }^{14}$ Há também versões mais próximas da abordagem sociológica como a de Jan Pieterse e Rehbein em "Globalization and Emerging Societies: Development and Inequality", quando, em 2009, julgaram o termo "emerging powers" como muito ligado à noção de poder estatal na política internacional e o termo "emerging markets" muito voltado à oportunidade de negócios e de mercado e sugeriram o termo "emerging societies", o qual incorporaria aspectos sociológicos e societais às definições de países ascendentes no sistema internacional, como o nível de distribuição da riqueza gerada por aquela sociedade e a percepção nacional de potência (PIETERSE; REHBEIN, 2009).
} 
Conquanto a "ressurgência" chinesa seja uma grande transição de poder no sistema internacional, a emergência de atores não estatais trata-se da grande difusão de poder desde a década de 1980 (NYE, 2011). As reformas praticadas pelos governos dessa década em países asiáticos, latino-americanos e do Leste Europeu impulsionariam a atuação global de corporações empresariais, que adquiriram importância crescente na economia internacional. A crescente atividade transnacional de empresas anteriormente fincadas em fronteiras nacionais, somada à abertura da conta de capital dos países emergentes e em desenvolvimento, permitiram a expansão de investimentos produtivos em novas regiões, sobretudo na forma de Investimento Estrangeiro Direto - IED. A maior abertura aos IEDs pode ser interpretada também como uma flexibilização do nacionalismo econômico (WILLIAMSON, 1990) e, ainda hoje, em países de orientação "capitalista de Estado". Uma das motivações para esse receio baseia-se no fato de que os IEDs impõem algum tipo de remessas de lucros ao exterior, ou seja, do trabalho e da produção nacional. Não obstante, conforme relatado por Almeida (2013a, p.31), "são as empresas, em primeiro lugar, não os governos, que impulsionam o fenômeno conhecido como globalização, a tendência mais evidente em nossa época, junto com a própria regionalização".

As economias de mercado ressaltam e tendem a dar uma maior liberdade às empresas e agentes individuais na produção e circulação de riqueza, além de conduzirem uma alocação econômica mais eficiente. Por sua vez, as firmas e tais agentes buscam a expansão dos mercados e, com isso, impulsionam a participação do país na arena global (BHAGWATI, 2004; PIO, 2002). Ações de coordenação entre governo e empresas tornaram-se mais frequentes com a democratização latinoamericana e Europa Oriental, inclusive como suporte à participação de Estados em movimentos de integração regional. De acordo com Hoekman e Kostecki (2001, p.350), o fator relacionado ao aumento do poder de barganha de um país no sistema comercial multilateral também é valorado pelas empresas multinacionais em um esquema de integração regional: "multinational firms (...) may actively support the RIA (Regional Integration Agreement) if they perceive that the negotiation power of the bloc enhances the probability of obtaining greater access to third markets".

As empresas transnacionais são atores indispensáveis e centrais tanto na expansão do comércio internacional como no desenvolvimento das cadeias produtivas regionais e globais. Com o seu crescimento e alargamento, as firmas almejam estratégias de investimento produtivo de escopo global, aproveitando as vantagens 
comparativas e competitivas em diversas áreas do mundo, tornando-se parcialmente independentes de seus países de origem e aproveitando economias de escala (VIOLA; LEIS, 2007, p.37). Somado a isso, a desintegração da produção por si só leva ao aumento de comércio, na medida em que bens intermediários cruzam as fronteiras diversas vezes durante o processo manufatureiro.

Segundo Baldwin (2012), são três grandes complexos de países que com o tempo deram surgimento a uma integração comercial e desintegração da produção, formando cadeias globais de valor: Leste Asiático, Europa (especialmente, a ocidental), e América do Norte. Cada grande CGV possui um país líder que apresenta uma centralidade na entrada de bens intermediários para os parceiros do mesmo esquema de integração e venda de bens finais para estes. Esse é um processo que se autoalimenta, do qual é possível reduzir custos de produção e beneficiar-se das distâncias reduzidas para as trocas comerciais.

O processo de fragmentação e dispersão da produção transnacional só foi possível ser globalizado (do mesmo modo, a evolução de uma cadeia regional de valor para uma cadeia global de valor) a partir da revolução tecnológica e de telecomunicações, por meio do barateamento dos custos de transporte, transação e de comunicação, bem como redução do tempo de tratamento dos termos burocráticos para o ciclo de negócios em escala global. Para Martin Wolf (2001), "a mudança tecnológica durante os últimos cinco séculos tem reduzido progressivamente as barreiras para a integração internacional". Os processos contínuos de fragmentação, dispersão, terceirização e transnacionalização da produção deram origem às chamadas cadeias globais de valor - CGV. Nesses padrões de comércio, os países procuram especializar-se em atividades que adicionem valor a produtos, não somente na especialização da produção de determinados bens finais. Os ganhos de especialização dentro de uma CGV são assimétricos e os maiores benefícios advêm do início e do final do processo produtivo, conforme figura abaixo. 
Figura 3 - Smile Curve - Estrutura de adição de valor em cadeia produtiva de capital baseado em conhecimento nos anos 1970 e nos anos 2000

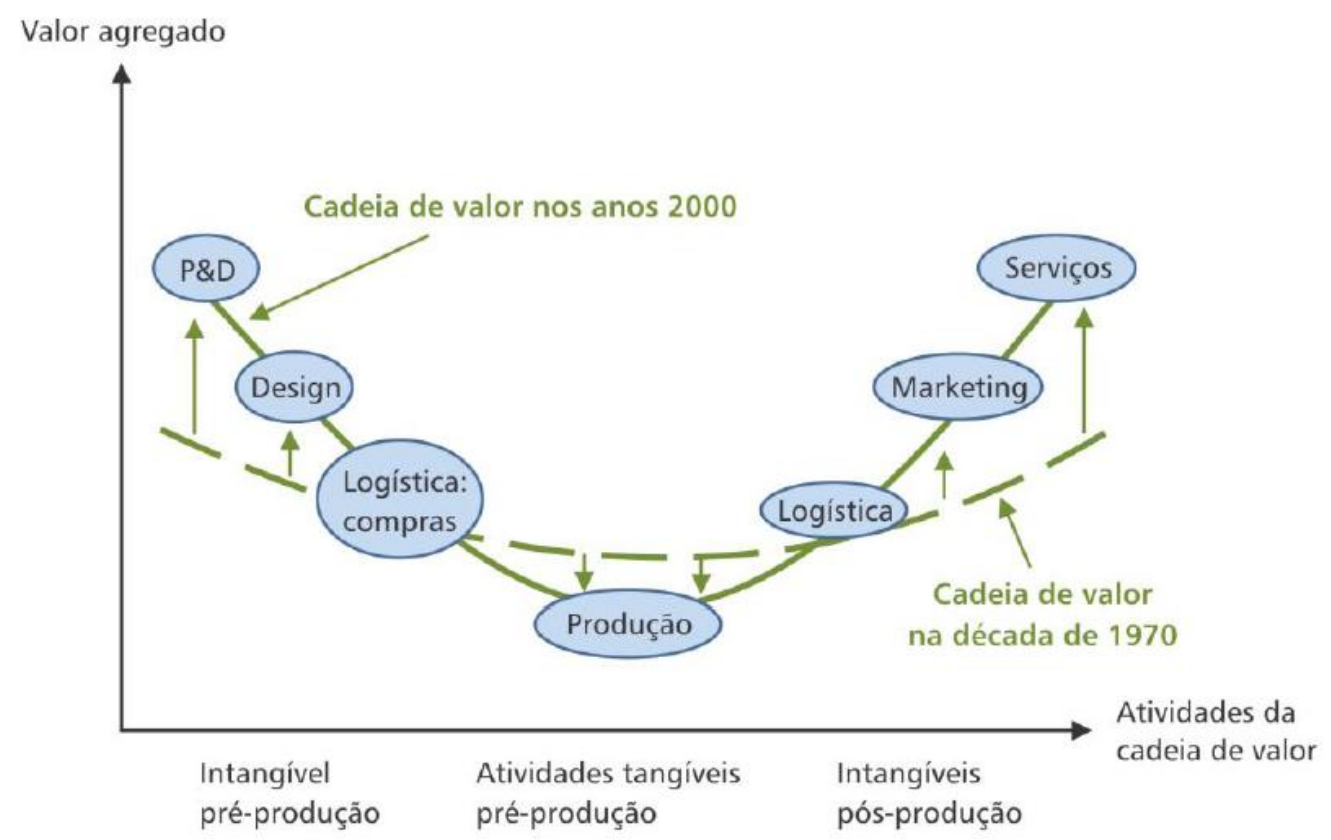

Fonte: OLIVEIRA, 2014, p. 96, traduzido do original de BACKER, 2013.

Como afirmam Sturgeon et al. (2013), os benefícios não são igualmente distribuídos ao longo da cadeia de valor, sendo as empresas líderes as que mais lucram com o processo. Geralmente, essas empresas encontram-se nos extremos da cadeia de valor e contratam fornecedores para a produção, etapa central do processo. Há uma procura por baixos custos produtivos, sendo essa uma das razões pela qual grande parte dessa etapa do processo centra-se nos países emergentes asiáticos, no leste europeu e em maquiladoras mexicanas, por exemplo. Nas extremidades da cadeia, exige-se um maior grau de formação de capital humano e inovações, o que faz com que estas etapas sejam concentradas nos países avançados e recém-emergidos da renda média, como a Coreia do Sul.

Baldwin (2011) descreve a mudança no sentido da globalização produtiva em duas grandes etapas. $\mathrm{O}$ primeiro grande processo de fragmentação $-1^{\text {st }}$ unbundling teve como mola propulsora a revolução a vapor, que reduziu drasticamente os custos de transporte e incentivou a construção de rodovias e navios a vapor, tornando mais viável a separação da produção e do consumo. A segunda grande separação, $2^{\text {nd }}$ unbundling, teve como fontes de impulsos as revoluções das telecomunicações e informações, das capacidades de transmissão e computadores, que tornaram economicamente viáveis as 
separações de estágios de produção manufatureira geograficamente. Em ambas transformações, as economias de escala e vantagens comparativas foram fundamentais para a expansão do comércio e da produção internacional (BALDWIN, 2011, p. 10-13).

Há quem diga que esse fenômeno representa uma "nova revolução industrial", com uma desverticalização da produção em escala global. As indústrias estão sendo reordenadas ao passo que a inovação em processos e produtos se acelera e as barreiras para entrada de investimento estrangeiro direto são reduzidas (RASKIN; MELLQUIST, 2005).

Para a OCDE (2013), a maneira como as cadeias globais de valor afetam a política comercial é única na história. O protecionismo torna-se mais custoso para os ganhos possíveis, tanto que, "[a]fter more than a half a century of trade liberalisation, nominal tariffs on manufactured products in developed economies are generally low" (OCDE, 2013, p.15). No contexto das CGVs, as tarifas são cumulativas quando bens intermediários são comercializados entre as fronteiras por diversas vezes, inclusive o bem final. Do mesmo modo, bens de capital mais caros desestimulam a participação de um país em um processo produtivo transnacional (OCDE, 2013). Um fato comum em praticamente toda a Ásia são os baixos níveis de proteção para produtos semiprocessados (BAUMANN, 2013a; ESTEVADEORDAL; BLYDE; SUOMINEN, 2013).

A redução de barreiras comerciais incentivou a dispersão geográfica de indústrias que anteriormente atuavam como entidades exclusivamente nacionais, passando a atuar em redes de produção internacional na especialização de tarefas e determinadas atividades e não unicamente na produção de bens finais.

As cadeias globais de valor alteram a percepção sobre o desenvolvimento, as estratégias empresariais, as opções de política industrial, comercial e de política externa. A integração vertical baseada na agregação de valor em um único local e/ou única empresa passou a dar lugar a um novo modelo de gestão, de integração horizontal, no qual a atividade de concepção, produção e venda de um produto passa a ser fragmentada e dispersa internacionalmente.

A literatura do século XXI, que chama a atenção para o aspecto em forma de redes (networks) da integração descrita, costuma definir o país central como hub (eixo, ponto central) e os parceiros menores como spokes (raios) (BALDWIN, 2011; IAPADRE; TAJOLI, 2013). Os Estados Unidos possuem posição central nas CGVs da América do Norte, cujo esquema de integração regional do NAFTA foi fundamental 
para inserir e dinamizar a economia industrial mexicana na região. O Japão é tradicionalmente o país hub da CGV do Leste Asiático e seus investimentos e demanda por bens intermediários ajudaram a fomentar o crescimento dos países corriqueiramente denominados como Tigres Asiáticos (PEREIRA, 2013). Devido ao crescimento extraordinário chinês após as reformas adotadas por Deng Xiaoping a partir de 1978, a China tem ganhado destaque também como hub na região (em especial, em uma integração produtiva com os países da antiga região da Indochina), mesmo não possuindo a capacidade inovadora e tecnológica do vizinho Japão (WTO, 2012a). O terceiro país que tem ascendido continuamente como exportador de bens finais para a região e para o mundo é a Coreia do Sul, país que possui uma entrada de bens importados na economia doméstica de mais da metade do valor seu PIB em 2012, por conta do processo de fragmentação da produção regional (WORLD BANK Data, 2014).

A evolução das cadeias globais de valor enseja também a alteração da percepção de poder e riqueza contemporânea. A busca por superávits comerciais não proporciona exatamente a melhor medida de perdas e ganhos com o comércio internacional, mas o quanto a nação adiciona valor a ele (OECD, 2013). De acordo com Anderson e Nash (2006), bem como com Rosecrance (1999), a ideia pura de "estoque", de viés mercantilista e nacionalista, embora tenha muita importância no que concerne ao capital bruto fixo, soma-se à noção moderna de "fluxos", que revela maior dinamicidade ao intercâmbio econômico entre os países. A visão "hierárquica" tradicional da política internacional passa a dar lugar à noção de "redes" (networks), a qual denota que o poder não está necessariamente com quem está "acima", mas com quem está no "centro" das conexões do sistema internacional (SLAUGHTER, 2006).

A importância crescente do conteúdo de serviços na era das cadeias globais de valor parece ser consenso entre os acadêmicos e especialistas. Rosecrance (1999) também já havia descrito a relevância desse processo em sua obra, ao discorrer que países no futuro próximo, como resultado de seu desenvolvimento e integração global, elevariam a participação das atividades de serviço, em termos de quantidade e qualidade, no produto nacional (ROSECRANCE, 1999).

O comércio internacional via adição de valor, como resultado do processo de globalização, por si só, aumenta o nível de interdependência internacional, o que também tende a aumentar os custos de oportunidade dos países que pouco participam do comércio internacional. Esse novo padrão de troca torna também menos clara a noção de "ganhos" com o comércio, já que a repartição dos benefícios econômicos entre 
nações não está centrada somente em qual produto final exporta, mas principalmente em qual etapa do processo a região ou país agrega valor ao produto. Além disso, as barreiras às importações podem ser um custo autoimposto às próprias exportações de bens de alto valor agregado.

Diante dessas alterações, é importante destacar que o aspecto da infraestrutura continua altamente relevante, bem como a indústria ainda permanece como fonte de capacitação técnica e não somente (embora ainda possa servir a esse propósito) à serviço da produção bélica.

A inserção nas CGVs também demanda uma maior ênfase nos acordos regionais comerciais que inserem os "novos temas" - serviços, compras governamentais, direitos de propriedade intelectual, padrões ambientais - em seus projetos de integração. Outra grande mudança, ou mesmo retomada teórica parcial, é a da importância da especialização no comércio e na produção. As teorias clássicas e neoclássicas tendem a ressaltar os ganhos decorrentes dessa atividade, segundo as quais o livre comércio aumenta a prosperidade, incentivando as nações a se concentrarem em seus pontos relativamente fortes (BHAGWATI, 2015).

Atualmente, a especialização produtiva estaria na execução de tarefas dentro de uma cadeia de valor, não necessariamente na produção de bens finais. Por último, a visão mais universalista e globalista de mundo ganha importância no contexto das CGV, ao aumentar o leque de oportunidades para a integração e inserção internacional econômica de um país e elevar os custos da priorização exacerbada por alguma região geográfica (geodeterminismo) ${ }^{15}$. Além disso, os novos padrões de comércio são uma oportunidade para o desenvolvimento industrial de países de industrialização tardia, como o Brasil, ao reduzir o tempo de catching up de países em desenvolvimento em relação aos desenvolvidos (OECD; WTO; UNCTAD, 2012).

\footnotetext{
${ }^{15}$ Nesse sentido, Almeida (2013) afirma que a globalização se dá em três eixos: comercial - pela intensificação dos vínculos comerciais; produtivo - pelo aumento dos investimentos diretos internacionais e à dinâmica das cadeias produtivas globais; e financeiro - pelos crescentes fluxos de capitais de todos os tipos entre as economias nacionais (ALMEIDA, 2013; VIOLA; LEIS, 2007). A aspiração de uma política externa globalista, então, poderia ser interpretada como uma procura por maior participação no comércio internacional, nas cadeias produtivas globais e na atração de Investimentos Estrangeiros Diretos e capitais externos.
} 


\section{A Obsolescência dos Regimes Internacionais e de Estatísticas de Comércio Exterior}

O processo de transformação tecnológica e a interdependência econômica crescente tornam em parte "desatualizados" ou mesmo obsoletos os regimes internacionais existentes e instituições (KEOHANE; NYE, 2011, p. 33). Como afirmam Katzenstein, Keohane e Krasner, "international organizations are profoundly affected by world politics, and these organizations' transformative potential is modest, at least in the short run" (1998, p. 651). O regime internacional do comércio é um dos que mais necessitam de atualização para representar de uma forma mais efetiva as relações comerciais e produtivas, que passaram por grandes transformações ao longo da década de 1990 e que se intensificaram no século XXI (NADEAU, 2014). As estatísticas de comércio exterior centradas nas exportações e importações ainda são relevantes no tocante à facilitação da contabilização de trocas comerciais. No entanto, podem ser consideradas atualmente limitadas ou parcialmente obsoletas no que tange à mensuração de perdas e ganhos com o comércio e a produção internacionais, assim como pela múltipla contagem de trocas de insumos. Além disso, como afirma Canuto (2014a), as estatísticas tradicionais "não servem mais como meio de aferir como o comércio exterior de um país afeta a alocação de seus fatores de produção" (CANUTO, 2014a, p. 42).

Há também uma maior dificuldade inerente à certificação das "regras de origem" de diversos produtos provenientes das cadeias de valor, tendo em vista que muitos países especializam-se em tarefas determinadas de um mesmo processo produtivo. Muitos dos produtos que passam por um alto grau de transformação não mais passariam a não ser "made in China" ou "made in Taiwan", mas "made in the world" (NADEAU, 2014). Nadeau ilustra esse processo por meio do exemplo da produção do modelo de avião Boeing 787 Dreamliner: a barbatana caudal utilizada para a estabilização vertical do avião é produzida nos Estados Unidos, a fuselagem principal na Itália, as portas de entrada na França, e as partes restantes do modelo, incluindo os eletrônicos, são feitos em outros lugares (NADEAU, 2014).

Um exemplo simples e corriqueiro, e que corrobora a necessidade de revisão das estatísticas, é a partição dos lucros entre países da cadeia de produção do celular iphone 4, processo do qual participam mais intensivamente cinco países: Estados Unidos, 
China, Taiwan, Alemanha e Coreia do Sul. A tabela abaixo mostra a balança comercial dos EUA, onde o produto é originalmente concebido, com a China.

Tabela 1 - Balança comercial dos EUA em iphones S4 (milhões de dólares US\$)

\begin{tabular}{ccccccc}
\hline & China & Taiwan & Alemanha & $\begin{array}{c}\text { Coreia do } \\
\text { Sul }\end{array}$ & $\begin{array}{c}\text { Resto do } \\
\text { Mundo }\end{array}$ & Mundo \\
\hline $\begin{array}{c}\text { Valor bruto (medida } \\
\text { tradicional) }\end{array}$ & - & 0 & 0 & 0 & 0 & $-1,646$ \\
\hline Valor adicionado & -65 & -207 & -161 & -800 & -413 & $-1,646$ \\
\hline
\end{tabular}

Fonte: OECD/WTO (http://www.oecd.org/sti/ind/49894138.pdf).

$\mathrm{O}$ que se verifica na medida tradicional é que se contabiliza à China o valor bruto da exportação final do produto para os EUA, quando, na verdade, o valor adicionado ao produto pela China está bem abaixo do valor adicionado pela Alemanha, Taiwan, Coreia do Sul e do restante do mundo. Cabe destacar que, além da partição dos lucros decorrentes do valor adicionado, processos produtivos de fácil segmentação e dispersão internacional de tarefas tornam menos imediata e menos clara a noção de ganhos com exportações ao considerar também a dimensão da propriedade de capital e as remessas decorrentes.

\section{Os Avanços Tecnológicos e os Desafios para a Inserção nas CGV}

O desenvolvimento tecnológico pode levar a um fatiamento mais fácil da produção, assim como o desenvolvimento da comunicação e do transporte (OECD; UNCTAD; WTO, 2013). Políticas de liberalização comercial tendem a aumentar o comércio, o que leva a um aumento da fragmentação e vice-versa. Além disso, como afirmam os economistas Anderson e Nash (2006, p.128), "more-open economies also tend to be more innovative, because of greater trade in intellectual capital (information, ideas, and technologies, sometimes but not always in the form of purchasable intellectual property)". Diante desse cenário, o Brasil deve criar condições para uma economia de mercado aberta, a fim de angariar os benefícios da alocação eficiente das etapas de um processo de produção e investimentos plausíveis em infraestrutura, transporte e logística. 
O tempo é um fator considerável para a inserção de empresas nas cadeias globais de valor e para a abertura comercial de países que desejam o aumento da competitividade industrial. A economia mundial está sendo globalizada em matéria produtiva e comercial de forma ascendente no século XXI, apesar do retrocesso com a crise econômico-financeira de 2008, mas com um retorno da globalização maior do que o período anterior à crise. Surge, em virtude disso, a hipótese de "aceleração da história" (GORE, 2013; VIOLA; FRANCHINI; RIBEIRO, 2013), o que demanda maior premência quanto ao ativismo de uma política econômica externa, de modo que possa antecipar os efeitos das mudanças estruturais da economia global e evite que haja uma desatualização dos termos em negociação em acordos comerciais.

Essa hipótese de aceleração da história pode ser evidenciada por meio de outra grande transformação na economia global, porém de forma menos globalizada do que a formação das cadeias globais de valor, em virtude dos custos e das diferenças nacionais de capital: trata-se da "automação tecnológica da produção industrial". Também chamada de robosourcing, Al Gore (2013) a descreve como "robosourcing de trabalhos de seres humanos para processos mecanizados, programas de computador, robôs de todos os tamanhos e modelos, além ainda de rudimentares versões de inteligência artificial, que estão melhorando a eficácia, utilidade e poder a cada ano". (GORE, 2013, p. 5, tradução nossa). Exemplo desse processo é a impressora 3-D, uma das inovações tecnológicas que possuem impacto considerável no processo industrial ao reduzir custos de produção e de mão de obra.

Embora a formação das cadeias globais de valor seja um processo distinto da robotização industrial, para Brynjolfsson, Mcafee e Spence (2014), o processo de terceirização internacional "é muitas vezes apenas uma estação de passagem para o caminho da automação", na medida em que possibilita a empresas locais a aquisição de tecnologias mais sofisticadas em mercados mais competitivos e eficientes.

Diante disso, os avanços tecnológicos também impõem desafios para a inserção nas cadeias globais de valor existentes. Além dos benefícios quanto à maior eficiência econômica, ganhos de produtividade e menores custos de produção, há o risco de que avanços em termos de tecnologia em automação industrial acelerada possam impactar negativamente uma das vantagens de países emergentes na inserção nas cadeias globais de valor: os baixos salários e custos de produção (BRYNJOLFSSON; McAFEE; SPENCE, 2014). Justamente por substituir mão de obra barata por processos cada vez mais mecanizados, com sofisticados programas de computador e inteligência artificial, 
pode-se reduzir a demanda nos países considerados desenvolvidos ou centrais por terceirização da produção industrial a países emergentes e em desenvolvimento.

Essas duas grandes transformações combinadas - cadeias globais de valor e robosourcing - mudam a relação entre capital e trabalho tradicional (GORE, 2013; BRYNJOLFSSON; McAFEE; SPENCE, 2014). As máquinas inteligentes e outras inovações ajudam a multiplicar capitais, fazendo com que o capital e a força de trabalho sejam dotados de menor importância relativa às próprias inovações. Com isso, as pessoas com ideias e capacidade inovadora tornam-se os recursos mais escassos no futuro próximo da economia global. É justamente na parte mais nobre e inicial de um processo produtivo inserido nas cadeias globais de valor que o potencial inovador se encontra.

Entretanto, isso não significa que um Estado deva procurar a todo custo aumentar o nível de componentes domésticos na produção e evitar a inserção nas cadeias de suprimento globais. Na medida em que a estrutura de uma cadeia de valor centrada em knowledge based capital (como eletrônicos) apresenta uma concentração maior de benefícios nas duas pontas da cadeia - "concepção e design do produto" e "marketing e serviços de exportação final" -, o país que queira inserir-se qualitativamente nesse processo demandará uma maior qualificação da mão de obra (BACKER, 2013). Outras medidas tornam-se centrais, tais como maiores investimentos em Pesquisa e Desenvolvimento - P\&D, tanto em âmbito público quanto privado, e um ambiente favorável ao empreendedorismo e inovação. Adicionalmente, melhorias nas condições de infraestrutura e logística são áreas-chave para condicionar uma inserção mais eficiente em cadeias globais de valor ${ }^{16}$, a fim de evitar a clausura nacional em camadas mais baixas e menos rentáveis da produção internacional. Investir é extremamente necessário.

\footnotetext{
${ }^{16}$ Sturgeon et. al. (2014, p.15) descrevem que "as cadeias globais de valor geraram investimentos em novas capacidades produtivas e grandes melhorias na infraestrutura de países em desenvolvimento, especialmente em países produtores como a China".
} 


\subsection{As Teorias Tradicionais de EPI e os Novos Padrões de Comércio Internacional}

A formação das Cadeias Globais de Valor enseja também mudanças importantes na política internacional, per se, e no modo como as nações interpretam e lidam com suas opções de inserção internacional. Cabe, nesse sentido, uma breve análise desse novo fenômeno de fragmentação e dispersão da produção internacional aliado ao comércio via adição de valor (value-added trade), por meio das duas principais correntes de pensamento e ideologias historicamente associadas ao subcampo da economia política internacional, doravante, o nacionalismo e o liberalismo.

Essas duas ideologias, conforme Gilpin (2002), diferem na visão adotada "em torno do papel e do significado do mercado na organização da sociedade e da economia" (p. 43). Os novos padrões de comércio internacional tornam relativamente desatualizadas as noções de ênfase na balança comercial superavitária. Em decorrência desses novos padrões atrelados ao moderno sistema comercial, a especialização no cumprimento de tarefas em certas atividades dentro de redes inter e transnacionais de produção torna-se mais adequada às oportunidades de ganhos com o comércio, adicionando valor, do que a especialização na produção de bens finais (CATTANEO; GEREFFI; STARITZ, 2010). Esta última tende a tornar-se mais custosa, em especial, para os países emergentes e pobres, que não desfrutam muitas vezes de condições adequadas de infraestrutura, carga tributária, logística e salários, como é o caso do Brasil.

Essas atualizações de políticas em prol de especializações mais restritas quanto a bens finais e em prol de um produto a ser concebido fora das fronteiras nacionais, assim como de perda relativa de controle nacional sobre o processo de produção, implicam, em certa medida, a redução da autonomia e soberania nacional. Das duas tradicionais teorias da EPI, a teoria liberal é a que melhor se adapta aos novos padrões de comércio internacional, pois enfatiza o "jogo de soma positiva" da economia internacional, no qual países participantes podem beneficiar-se sem necessariamente prejudicar outro país, mesmo que nem todos ganhem de forma uniforme, uma vez que há diferenças na produtividade. Quanto ao nacionalismo econômico, que possui suas vertentes originais baseadas no mercantilismo e na acumulação de capitais, sob o primado da política sobre a economia e, assim, tende a resguardar ainda mais a soberania e autonomia nacional no campo econômico, atribuindo limites e maiores restrições cognitivas à inserção de um país nas Cadeias Globais de Valor. Além disso, como ideologia, o nacionalismo 
econômico destaca o intercâmbio internacional comercial como uma espécie de "jogo de soma zero", no qual para que um país se beneficie do comércio, algum outro terá que perder.

Há também custos aos países caso resistam ao fenômeno da interdependência de modo ao sugerido no campo de inspiração marxista, como exposto pela teoria da dependência, segundo a qual haveria um aumento da dependência (e, por conseguinte, exploração) de países periféricos em relação aos países centrais decorrente da evolução do sistema econômico internacional. Para Cardoso e Faletto (1979) ${ }^{17}$, uma razão essencial para a dependência das economias periféricas produtoras de matérias-primas seria a debilidade dos seus setores de produção de bens de capital (relativamente caros) e baixas condições para o seu financiamento. Nesse sentido, a ausência de capital financeiro para a produção faz com que os países periféricos o busquem nos países desenvolvidos. Os autores utilizam a analogia de um cliente com um banqueiro, uma relação de mútua dependência, em que o primeiro torna-se mais pobre e o segundo mais rico ao longo da relação (CARDOSO; FALETTO, 1979). Com a intensificação do processo de globalização, tais preceitos se tornaram em grande parte suplantados. A partir da década de 1990, em especial, houve uma maior mobilidade de recursos financeiros para os emergentes e a abertura comercial também se tornou em parte favorável às exportações de bens de alto valor agregado. Além disso, houve um crescimento de países via exportação e produção de commodities - como o próprio Brasil e Rússia - e denotou-se a possibilidade de ascensão na escala industrial no sistema econômico internacional, a exemplo dos países do Leste Asiático.

O quadro abaixo apresenta possíveis implicações importantes (em resumo) dos novos padrões de comércio internacional na política internacional contemporânea além das questões de natureza técnica inerentes ao comércio per se. Por mais que não possam configurar-se como mudança com a formação das $\mathrm{CGV}$, as recomendações da segunda

\footnotetext{
${ }^{17}$ De acordo com os autores, "[a]lmost all contemporary national economic systems are articulated in the international system. Superficial or apologetic analysts, in order to minimize exploitative aspects of the international economy, have merely assumed that 'modern' economies are 'interdependent'. By stating this platitude, they often forget that the important question is what forms that 'interdependency' takes. While some national economies need raw material produced by unskilled labor, or industrial goods produced by cheap labor, others need to import equipment and capital goods in general. While some economies become indebted to the financial capital cities of the world, others are creditors. Of course, bankers need clients, as much as clients need bankers. But the 'interrelationship' between the two is qualitatively distinct because of the position held by each partner in the structure of the relationship. The same is true for the analysis of 'interdependent' economies in world markets" (CARDOSO; FALETTO, 1979, p. xxi).
} 
coluna são tendências reforçadas para o upgrading no novo padrão de comércio. Já a primeira coluna traz noções da política e economia mais centradas no nacionalismo econômico.

Quadro 2 - Mudanças na percepção da política internacional, antes e depois das CGV

\begin{tabular}{|c|c|}
\hline $\begin{array}{l}\text { Comércio tradicional via relação superávit- } \\
\text { déficit }\end{array}$ & Comércio via valor adicionado \\
\hline Ênfase nos estoques & Ênfase nos Fluxos e Estoques \\
\hline Especialização em bens finais & Especialização em tarefas \\
\hline Visão de mundo em forma de Hierarquia & $\begin{array}{l}\text { Visão de mundo em forma de Redes } \\
\text { (networks) ou Subway maps }\end{array}$ \\
\hline Ênfase na proteção contra os efeitos globais & $\begin{array}{l}\text { Estabilidade macroeconômica como proteção } \\
\text { perante a "inevitabilidade do choque externo" }\end{array}$ \\
\hline $\begin{array}{l}\text { Estratégia de desenvolvimento via } \\
\text { substituição de importações }\end{array}$ & $\begin{array}{c}\text { Estratégia de desenvolvimento via } \\
\text { Importações para ganhos de competitividade } \\
\text { e eficiência econômica e/ou promoção das } \\
\text { exportações }\end{array}$ \\
\hline $\begin{array}{l}\text { Ênfase no aspecto da "autonomia" e } \\
\text { "soberania" no desenvolvimento }\end{array}$ & $\begin{array}{l}\text { Relativização da autonomia e soberania para } \\
\text { a integração efetiva }\end{array}$ \\
\hline $\begin{array}{c}\text { Liberalização via redução de barreiras } \\
\text { tarifárias }\end{array}$ & $\begin{array}{c}\text { Liberalização via redução também de } \\
\text { barreiras não tarifárias e harmonização } \\
\text { regulatória }\end{array}$ \\
\hline
\end{tabular}

Fonte: elaboração própria.

\subsection{A Crescente Interdependência Econômica e a Assimetria de Ganhos}

$\mathrm{O}$ ex-vice-presidente americano $\mathrm{Al}$ Gore descreve em seu livro The Future: the six drivers of global change as principais mudanças de impacto global que moldarão o futuro da civilização. Uma delas é justamente o fato de que a economia global está se tornando cada vez mais interconectada e interdependente, fenômeno cuja aceleração provocará grandes alterações nas relações de fatores de produção, fluxos de capitais, trabalho, mercados de consumo e governos nacionais, de forma muito distinta do passado (GORE, 2013). Essas mudanças demandarão ações concertadas em matéria de 
governança global, além de novas percepções de desenvolvimento por parte das lideranças políticas nacionais.

A interdependência pode ser compreendida como um resultado (outcome) de mudanças provocadas pelo fenômeno da globalização. Difere-se, portanto, do multilateralismo, patamar de negociação mais amplo pelo qual países contornam desafios ao mesmo tempo em que buscam aproveitar de forma mais eficaz as oportunidades oriundas da interdependência. O que se verifica após a crise de 2008, em especial, em matéria comercial, é uma queda da eficiência do multilateralismo, mas não necessariamente da interdependência. Desde meados da década de 1970, as nações estão se tornando mais interdependentes em termos de fluxos comerciais de bens e serviços e de capitais financeiros. Essas interconexões entre as nações foram, ao longo do tempo, intensificadas pelos investimentos estrangeiros diretos e pela subcontratação internacional (GEREFFI, et al., 2001). Esse aumento da interdependência foi, com destaque à década de 1990, elevando a intensidade dos fluxos entre países desenvolvidos com países emergentes e de renda baixa, na medida em que estes procuraram realizar reformas de mercado para uma inserção mais competitiva no cenário internacional.

Cabe destacar que a distribuição dos ganhos dessa interdependência é assimétrica, pois depende da efetividade e posição ocupada pelo país na economia internacional (LAKE, 2009). Essa assimetria de ganhos é destacada por Kaplinsky (2000) em seu artigo Spreading the gains of globalization, no que se refere às cadeias de valor. Cabe destacar que essa assimetria de ganhos na CGV já era em parte tratada no campo da economia política internacional antes mesmo da formação do próprio conceito de CGV dos anos 2000's, a exemplo dos estudos do professor de Harvard, Richard Rosecrance, quando, em 1999, já sinalizava o processo de busca por participação nas altas instâncias das Cadeias Globais de Valor em The Rise of the Virtual State: Wealth and Power in the Coming Century. Para o autor, o processo de produção global envolvia nações "cabeça" - head nations -, que, por sua vez, seriam os Estados virtuais - encarregados da tarefa de formular o design e a concepção de produtos, responsáveis pelos bens intangíveis da economia e de alto valor, também denominados pelo autor de "products of mind"; e, as nações "corpo" - body nations -, que concentravam sua riqueza nacional em bens primários oriundos da disponibilidade de terra, terrenos agricultáveis e/ou abundância energética. Pode-se argumentar que os produtos oriundos das head nations, como as inovações e ideias, formarão uma das 
fontes de riqueza mais raras no mundo por vir do século XXI, muito mais do que a dicotomia capital-trabalho da economia convencional, conforme análise dos economistas Brynjolfsson, Mcafee, Spence $(2014)^{18}$ já descrita.

Para Rosecrance (1999), o século XXI seria marcado por uma revolução no tratamento da noção de riqueza nacional. Em suas palavras, "where the land is less important than an educated populace, where stockpiles of goods, capital, and labor are less important than flows, and where parochial interests are less important than the international economy as a whole" (ROSECRANCE, 1999, p. 3). Uma afirmação escrita na obra sugere uma internacionalização das economias nacionais para o crescimento e implicitamente defende a prática da terceirização da produção internacional: "Interdependent states have grown far more rapidly than autarchic economies. Those that have spread their industry to different countries and markets have gained greatly over those that produce only at home" (ROSECRANCE, 1999, p. xiv).

A literatura acadêmica e as evidências empíricas demonstram que não há no mundo um único país que seja autossuficiente a tal ponto que possa manter um regime econômico autárquico, sem reduzir ou deixar de avançar em termos de bem estar social (BHAGWATI, 2003; MANKIW, 2013). Há diversos exemplos de práticas corriqueiras que corroboram isso: países tomam empréstimos internacionais, por vezes necessitam de resgate econômico de instituições internacionais, precisam participar de instituições que promovam os bens públicos globais e é comum o uso da expansão de exportações ou de complementaridade produtiva como fonte de riqueza e poder nacional ${ }^{19}$.

A globalização contemporânea demonstrou que um dos fatores que impulsionaram o crescimento dos países emergentes foi justamente o crescimento das nações desenvolvidas do eixo tradicional EUA - Europa Ocidental - Japão, representado pelo aumento da demanda desses países/regiões e dos investimentos no exterior (BALDWIN, 2012; ELMS; LOW, 2013). Como argumentam Markwald (2014) e Sato (2012), grande parte da pobreza do mundo conhecido anteriormente como "subdesenvolvido", e posteriormente "em desenvolvimento", foi reduzida pelo aumento do intercâmbio de fluxos com o mundo desenvolvido (via comércio, investimento,

\footnotetext{
${ }^{18}$ É importante destacar que em boa parte do mundo a percepção sobre o desenvolvimento sustentável tem crescido e a ciência tem corroborado a ocorrência da aceleração da mudança climática ocasionada pelo homem. O meio ambiente também é beneficiado na medida em que o componente intangível e informacional cresce em proporção na riqueza nacional (ROSECRANCE, 1999; ANDERSON; NASH, 2006).

${ }^{19}$ Os dois termos são comumente referidos na literatura de Relações Internacionais como os elementos que tendem a representar elementos da economia (riqueza) e política (poder). (Cf. GILPIN, 2001).
} 
produção, conhecimento, tecnologia etc.), tendo como principais exemplos, China e Índia contemporâneas, os quais constituem $40 \%$ da pobreza do mundo (BHAGWATI; PANAGARIYA, 2014).

O Brasil também se beneficiou de condições externas ${ }^{20}$. Mesmo relativamente fechado ao comércio internacional de bens industriais, além de possuir poucos acordos de livre comércio (e quando possui, é de curto alcance temático), o país cresceu a taxas moderadamente altas no período 2004-2011. Em grande parte, esse crescimento foi patrocinado por eventos externos, que proporcionaram condições excepcionalmente favoráveis ao país, gerando altos superávits comerciais e no balanço de pagamentos (BACHA, 2014). A explosão do crescimento da China no século XXI foi um desses eventos. O país somente alcançou seu primeiro trilhão de dólares em PIB corrente em dólares no ano de 1998 (World Bank data, 2015) e é atualmente a segunda economia global $^{21}$.

A avaliação da balança de efeitos positivos e negativos da integração econômica global não é dotada de grandes consensos. Há um debate constante entre economistas sobre os efeitos da integração de uma economia em desenvolvimento na globalização econômica. Por um lado, há aqueles que destacam os limites da globalização e seus efeitos dolentes à distribuição de renda global e políticas supostamente associadas ao chamado Consenso de Washington, a exemplo de Joseph Stiglitz ${ }^{22}$ e do professor Dani Rodrik $^{23}$. Por outro lado, há aqueles que enfatizam as oportunidades criadas pela globalização contemporânea para países em desenvolvimento como a superação da pobreza e ganhos de produtividade e eficiência, bem como externalidades positivas oriundas da assimilação de padrões mais exigentes, a exemplo do professor indiano da Columbia University, Jagdish Bhagwati ${ }^{24}$, e Martin Wolf ${ }^{25}$, economista chefe e editor associado do jornal britânico Financial Times.

Um dos possíveis impactos aos países que procuram uma integração mais ativa na globalização diz respeito à redução dos impostos ou taxas por parte de Estados

\footnotetext{
${ }^{20}$ Este ponto é explorado com maior detalhe no capítulo 2.

${ }^{21}$ De forma surpreendente aos olhares dos dias de hoje, em 1989 o PIB brasileiro era maior do que o PIB chinês.

${ }^{22}$ Cf. STIGLITZ, Joseph E. Globalization and its Discontents. New York and London: W.W. Norton \& Company, 2002.

${ }^{23}$ Cf. RODRIK, Dani. The Globalization Paradox: Democracy and the Future of the World Economy. New York: W. W. Norton \& Company, 2011.

${ }^{24}$ Cf. BHAGWATI, Jagdish. In Defense of Globalization. New York: Oxford University Press, 2004.

${ }^{25}$ Cf. WOLF, Martin. Why Globalization Works. New Haven, Conn.: Yale University Press, 2004.
} 
nacionais. Essa proposição é defendida pelo professor Dani Rodrik (2011), o qual relata que um aumento da inserção de um Estado na globalização reduziria a capacidade de taxação por parte dos governos para adoção de programas sociais e manutenção de "setores estratégicos". Questionando se o fenômeno da globalização implicaria no fim do Estado-nação e suas atribuições, Martin Wolf (2001) enfatiza o contrário de Rodrik, ao afirmar que há um aumento de margem de atuação do Estado na taxação de fluxos de capitais perante a integração econômica. Wolf argumenta que "a habilidade de governos de taxarem e redistribuírem rendas, regular a economia e monitorar a atividade de seus cidadãos têm crescido além do reconhecível" (WOLF, 2001).

Eventuais custos da integração podem ser correlacionados com os custos derivados da noção de interdependência complexa, como descrito por Keohane e Nye (2011). Tratam-se da sensibilidade e da vulnerabilidade. O primeiro refere-se a uma característica relacionada ao modo como países podem, por meio da integração econômica, sentir os efeitos de mudanças ocorridas no ambiente externo. Já a vulnerabilidade estaria associada ao grau de capacidade dos Estados de lidarem com esses efeitos em âmbito interno (KEOHANE; NYE, 2011).

Ao buscar uma inserção mais profunda na interdependente economia global, um Estado pode auferir benefícios econômicos de médio prazo, mas também pode arcar com custos políticos decorrentes da redução temporária de bem estar a alguns setores econômicos em virtude da concorrência mais acirrada. Reformas de mercado, muitas vezes necessárias, quando realizadas, envolvem ajustes fiscais, privatizações de empresas estatais ineficientes e abertura comercial, que farão com que o governo arque com as diversas pressões internas para esse engajamento, sobretudo no contexto brasileiro e latino-americano, onde muitas são impopulares. Muitos Estados optam por restringir em grande medida essas reformas em virtude de seus custos políticos e com isso dificultam no médio prazo sua inserção na economia global.

Do ponto de vista estritamente comercial, a complexidade das trocas de fatores entre os países demanda uma maior universalização das relações de modo a não estabelecer um reforço das relações geodeterministas. Ao intercambiar bens, serviços e mercadorias, é facilitada a aquisição e trocas relacionadas à tecnologia, processos de produção, inovações de materiais, know-how e participação nas cadeias produtivas globais (MANKIW, 2013; ALMEIDA, 2013a). Conforme Almeida (2013b), ao longo da história, com algumas exceções - como a Índia, Israel e Coreia do Sul - o conhecimento e a inovação tecnológica foi se concentrando nos países mais avançados e 
mais desenvolvidos do Norte e somente após um determinado tempo estariam, mesmo que com certas barreiras, disponíveis ao restante do globo. Mas para isso, é recomendável que um país de desenvolvimento tardio ou emergente busque uma política universalista ou globalista e, assim, evite a adoção de um geodeterminismo na orientação de política externa. Diante disso, as políticas externas comerciais que aspiram ser globalistas poderão ser beneficiadas tanto no processo de aquisição de conhecimento, como no potencial de adaptação às novas dinâmicas do comércio internacional. 


\section{CAPÍTULO 2 - O CENÁRIO INTERNACIONAL FAVORÁVEL E A PRIMARIZAÇÃO DA PAUTA EXPORTADORA BRASILEIRA}

A economia brasileira no período 2004 a 2011 foi beneficiada por um cenário econômico internacional excepcionalmente favorável: taxas de juros internacionais continuamente baixas, grande disponibilidade de capital para investimento estrangeiro direto, e reversão dos termos de troca do comércio exterior do País. Essa combinação de elementos fez com que o Brasil atraísse massivamente capitais estrangeiros e elevasse os superávits em termos comerciais e no Balanço de Pagamentos.

Entretanto, a pauta exportadora do Brasil passou por um processo de primarização, que teria sido reforçada por políticas macroeconômicas domésticas e "conforto" com os influxos externos. Este capítulo objetiva descrever esse cenário, sob o argumento de que eram necessárias reformas e ações deliberadas para a competitividade das exportações do setor industrial frente às novas dinâmicas da economia global, para que assim o Brasil pudesse se adaptar mais efetivamente com o declínio do cenário externo amplamente favorável.

\subsection{O Cenário Econômico Internacional Favorável}

O Brasil experimentou um destaque internacional considerável como potência emergente, em especial após o relatório de 2001 "Building Better Global Economic BRICs" de Jim O’Neill, em virtude das estimativas de crescimento mais acelerado de Brasil, Rússia, Índia e China em relação aos países do G7. De acordo com Giambiagi (2011, p. 225), durante o governo Lula surgiu uma nova percepção interna e externa sobre o "novo papel do Brasil no mundo". O autor destaca a combinação de seis fatores para isso: (1) "a crescente importância da economia chinesa no mundo"; (2) "a avidez das economias emergentes por produtos dos quais o Brasil tornara-se grande produtor"; (3) "as potencialidades associadas à exploração do etanol"; (4) "as descobertas de petróleo do pré-sal"; (5) "os efeitos indiretos da crise de 2009 sobre a imagem do país"; e (6) "a escolha do Brasil para ser sede da Copa do Mundo de 2014 e do Rio de Janeiro como local das Olimpíadas de 2016".

A grande contribuição para esse mudança de percepção foi o fato de que a economia brasileira foi beneficiada por um ambiente estratégico internacional amplamente favorável no período 2003-2011, o que contribuiu para a inserção 
internacional do País (BACHA; BAUMGARTEN, 2013; GIAMBIAGI; SCHWARTSMAN, 2014). Fatores em grande parte exógenos às políticas adotadas pelo governo brasileiro contribuíram para o superávit comercial e superávit no balanço de pagamentos brasileiros. Segundo o Embaixador Sérgio Amaral, "o Brasil não teria experimentado as taxas de crescimento que atingiu, na primeira década do novo século, não fossem os investimentos que recebeu e o salto dos preços das commodities, em boa medida, em decorrência da demanda proveniente da China" (AMARAL, 2013, p.24).

\section{a) As Baixas Taxas de Juros Internacionais e a Entrada de Investimentos no Brasil}

As taxas de juros internacionais mostraram-se muito baixas em comparação à década anterior. De acordo com Giambiagi e Schwartsman (2014), dois indicadores da economia norte-americana funcionam como termômetro das taxas de juros internacionais: os Fed Funds de curto prazo, ou seja, títulos do Federal Reserve, Banco Central dos Estados Unidos; e a taxa de juros do Tesouro norte-americano. Desde 2003, com exceção dos dois anos antecedentes à crise de 2008 (2006 e 2007), as taxas Fed Funds apresentaram-se baixas. A partir de 2009, estas se revelaram extremamente baixas, próximas de zero (conforme a figura 5).

Figura 4 - FED funds rate

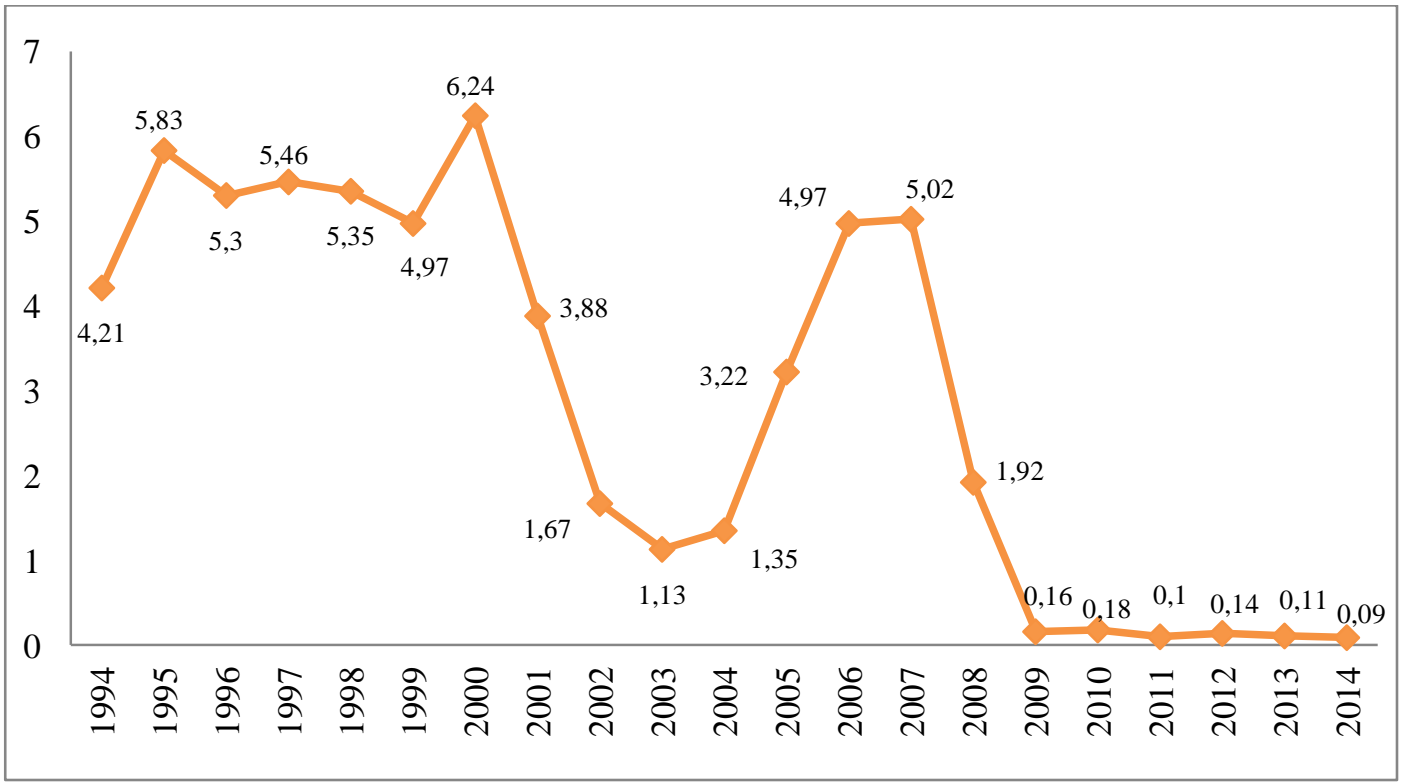

Fonte: elaboração própria a partir dos dados do Federal Reserve Bank. 
Quanto ao outro indicador, as taxas de juros de 10 anos do Tesouro dos EUA apresentaram uma queda constante de 2006, quando apresentou a média anual de 4,8, até 2012, quando a média chegou ao mínimo da década 1,8\% (conforme figura 6). Com os juros internos muito mais altos no Brasil do que no exterior, o ambiente era muito favorável ao país e atrativo aos investidores estrangeiros, o que motivou a entrada de investimentos e capitais estrangeiros no País, visto que apresentava grande retorno comparado aos investimentos na maioria dos países desenvolvidos (GIAMBIAGI; SCHWARTSMAN, 2014).

Figura 5 - Taxas de juros de 10 anos do Tesouro dos EUA - médias anuais (\% a.a.)

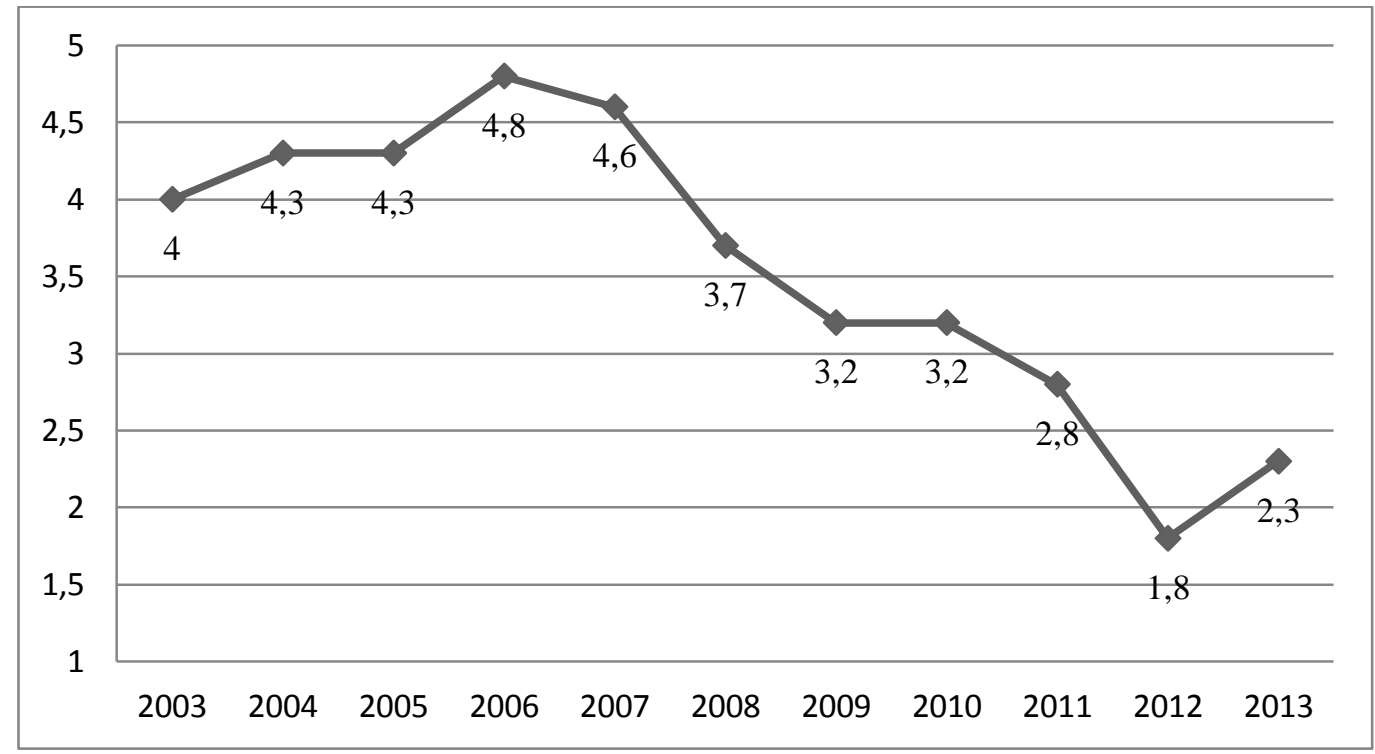

Fonte: Giambiagi; Schwartsman (2014) com dados do Federal Reserve.

De fato, foi justamente a partir de 2007 - quando, cabe retomar, tanto a taxa de juros dos títulos do Federal Reserve Bank quanto as taxas de juros do Tesouro dos EUA começaram a cair (no caso do FED, estas despencaram) - que o Brasil apresentou grandes superávits no tocante aos investimentos em carteira. Esses investimentos são conceituados pelo Banco Central do Brasil como "fluxos líquidos de ativos (investimento brasileiro em carteira - IBC) e passivos (investimento estrangeiro em carteira - IEC), constituídos por valores mobiliários comumente negociados em mercados secundários de títulos" (http://www4.bcb.gov.br/pec/series/port/ metadados/mg180p.htm). Esses investimentos são muito mais voláteis do que os investimentos diretos, em especial em crises financeiras, sendo assim então afetados 
pela conjuntura de curto prazo (http://www.receita.fazenda.gov.br/aduana/IDE/I DEBrasilCuba/ide.htm).

Figura 6 - Investimentos em carteira no BP do Brasil em US\$ milhões

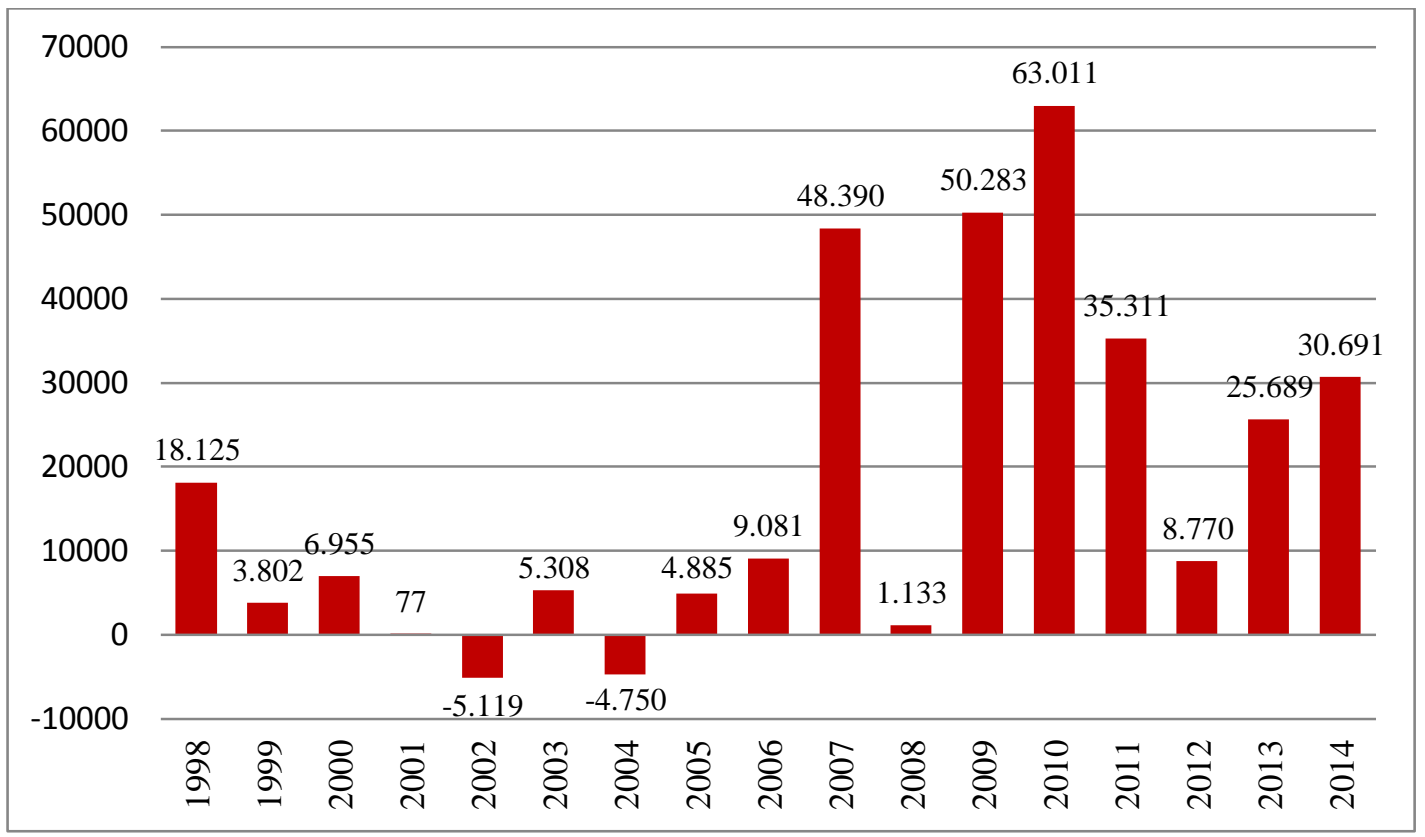

Fonte: elaboração própria a partir dos dados do Banco Central do Brasil.

O Brasil apresentou um superávit extraordinário nos investimentos em carteira da ordem de 48 bilhões de dólares americanos em 2007, representado um aumento de mais de 500\% em relação a 2006. Em 2008, no prelúdio do estouro da crise internacional, o superávit caiu para algo em torno de 1,1 US\$ bilhão. Em 2009, com os mercados desenvolvidos em baixa, houve uma grande entrada de investimentos estrangeiros no Brasil de mais de 50 bilhões de dólares, superando o valor de 2007. Mais uma vez, em 2010, o valor chegou a incríveis US\$ 63 bilhões, o máximo alcançado até então no século XXI. Em 2011, o valor caiu para US\$ 35 bilhões; voltou a cair para US\$ 8,7 bilhões em 2012; e elevou-se para US\$ 25 bilhões em 2013 e US\$ 30 bilhões em 2014. Há a expectativa que o Fed eleve a taxa de juros a partir de 2015, tornando o mercado norte-americano mais atrativo a investidores estrangeiros, o que poderá provocar uma saída de investimentos desse porte do Brasil. Caso isso ocorra, será de fato um fim de um ciclo altamente positivo para o País nesse aspecto.

Em relação aos Investimentos Estrangeiros Diretos (IEDs), de acordo com o World Investment Report 2013 da UNCTAD, o Brasil é o quarto maior receptor do mundo, atrás apenas de Estados Unidos $\left(1^{\circ}\right)$, China $\left(2^{\circ}\right)$ e Hong Kong $\left(3^{\circ}\right)$. Conforme a 
figura 11, após uma entrada rigorosamente baixa de 1 e 2 bilhões de dólares na primeira metade da década de 1990, um grande influxo de IEDs foi experimentado no Brasil na segunda metade da década de 1900 no governo Fernando Henrique Cardoso, em grande parte devido às privatizações de empresas estatais e processo de estabilização do ambiente macroeconômico. Todavia, o Brasil apresentou queda no IEDs na virada do século e no primeiro governo Lula (2003-2006). O País voltaria a obter o influxo recorde de US\$ 35 bilhões no segundo governo Lula em 2007, e novamente em 2008 (US\$ 45 bilhões). No contexto da crise de 2009, mais uma vez a entrada de IEDs cairia para 26 bilhões de dólares, e voltaria a crescer para 49 bilhões de dólares.

Figura 7 - Entrada de investimento estrangeiro direto (IED) em US\$ bilhões

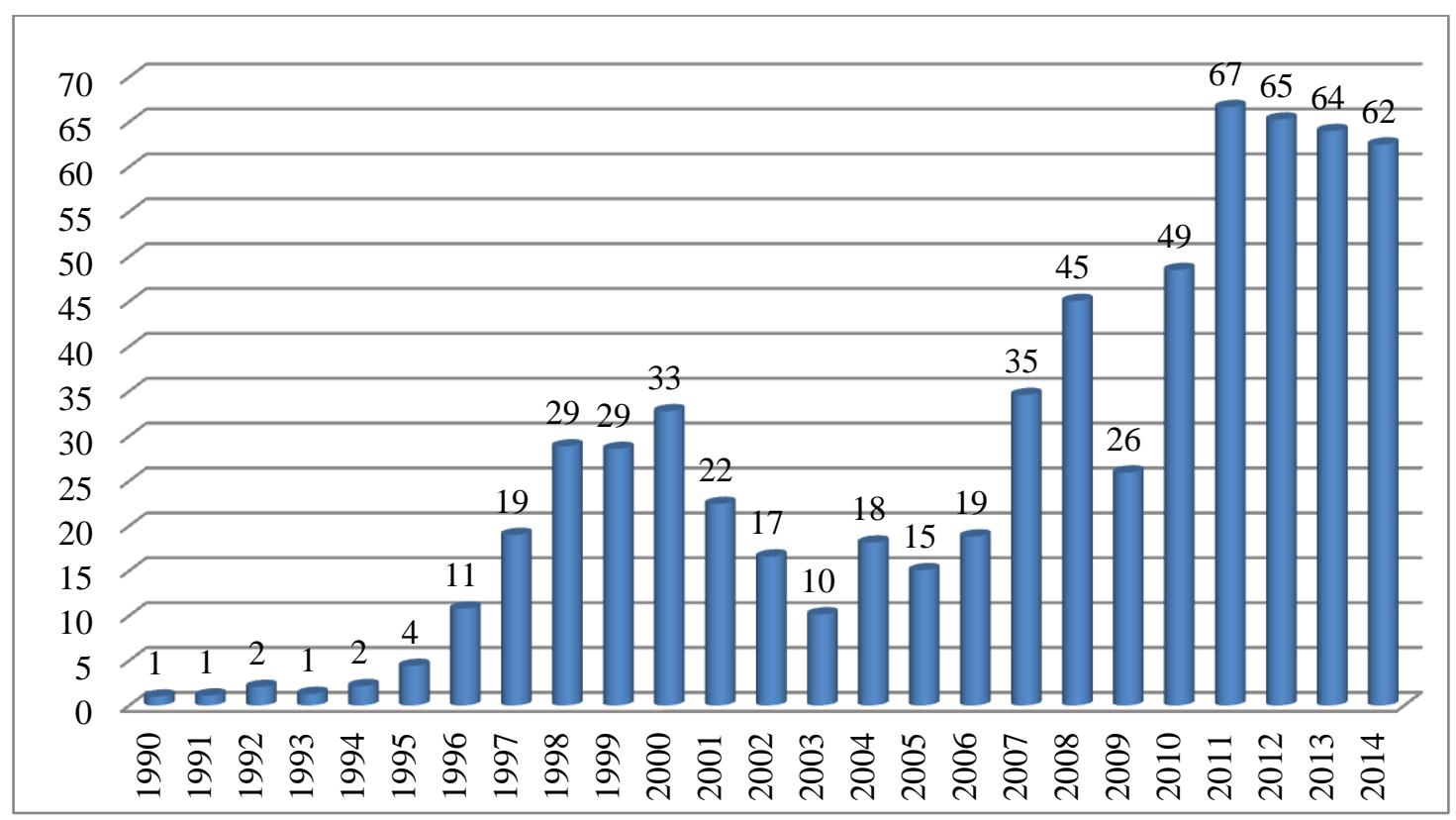

Fonte: elaboração própria a partir dos dados do Banco Central do Brasil - BCB.

O País apresentou uma série histórica de entrada de investimentos estrangeiros diretos no governo Dilma. No ano de 2011, o Brasil atingiu seu recorde histórico ainda não superado de 67 bilhões de dólares. Mesmo permanecendo em alto níveis, há uma gradual queda anual contínua: US\$ 65 bilhões em 2012, US\$ 64 bilhões em 2013, e US\$ 62 bilhões em 2014. Os IEDs têm se mantido como uma da principais fontes de financiamento do déficit na conta corrente brasileira.

Entretanto, ao analisar-se o tipo de IED, verifica-se uma queda nos investimentos do tipo inicial (grreenfield project), os quais produzem novas plantas industriais e portanto são mais benéficos para a formação da base do crescimento 
econômico (ITAÚ BAA data, 2015). Grandes entradas desse tipo de investimento foram verificadas no período de 2008 a $2011^{26}$. De acordo com dados da UNCTAD, a maior entrada de entrada de IEDs do tipo inicial no Brasil foi verificada em 2011, alcançando o valor de 56,888 bilhões de dólares. Em 2012, esses tipos de investimentos cairiam para 26,373 bilhões de dólares, e em 2013, somaram 29 bilhões de dólares.

Grande parte da argumentação para essa entrada de IEDs reside no fato de que investidores externos são atraídos pelos altos níveis de consumo interno no Brasil. De acordo com Bacha (2014, p. 7) e Baumann (2014b), as empresas multinacionais em território brasileiro não têm como objetivo integrar o Brasil às cadeias globais de valor, mas sim aproveitar os lucros obtidos do grande mercado interno brasileiro protegido pelo governo. Para Bacha, esse fator decorre da situação peculiar brasileira de possuir "um conta de capital aberta ao fluxo de investimento, mas uma conta corrente fechada ao fluxo de comércio", o que não ajuda a fomentar a eficiência econômica do Brasil do modo como é realizado nos países asiáticos (BACHA, 2014, p. 7).

\section{b) A Reversão nos Termos de Troca do Comércio Exterior Brasileiro}

No tocante ao aspecto comercial, a partir do ano de 2004 houve uma reversão parcial dos termos de troca do Brasil ${ }^{27}$, quando o preço dos bens exportados elevou-se em maior proporção do que o preço dos bens importados. A importância desse indicador reside na explicação da origem dos superávits comerciais, que não podem ser explicados simplesmente por um suposto aumento de produtividade da economia brasileira, mas, sobretudo, por fatores exógenos decorrentes em grande parte do aumento da demanda internacional por commodities. A ascensão dos mercados emergentes, em especial, da China, "implicou um choque de preços relativos, com barateamento de bens industriais e aumento dos preços de commodities, nos quais o Brasil tem vantagem comparativa, o que impactou de forma favorável as contas externas" (CRUZ et al., 2012). O gráfico abaixo mostra o índice de termos de troca do comércio exterior brasileiro, tendo como ano base 2006, com referência igual a 100.

\footnotetext{
${ }^{26}$ De acordo com a UNCTAD, em bilhões de dólares: 2008: 40,2 em 2008; 40,3 em 2009; 43,8 em 2010.

${ }^{27}$ De acordo com a FUNCEX, "o índice de termos de troca é obtido pela simples divisão do índice de preços de exportação pelo índice de preços de importação do país. Os cálculos contemplam dois diferentes níveis de agregação: (i) total das exportações e importações brasileiras e (ii) setores produtivos aos quais se relacionam os bens exportados e importados. Nesse último caso, adota-se a classificação CNAE 2.0 do IBGE. As séries têm periodicidade anual e mensal". Disponível em: <http://www.funcexdata.com.br/br/notas/nv2_indicettroca.pdf >. Acesso em: 15 abri. 2015.
} 
Figura 8 - Índice de termos de troca segundo total brasileiro Período anual Base: $2006=100$

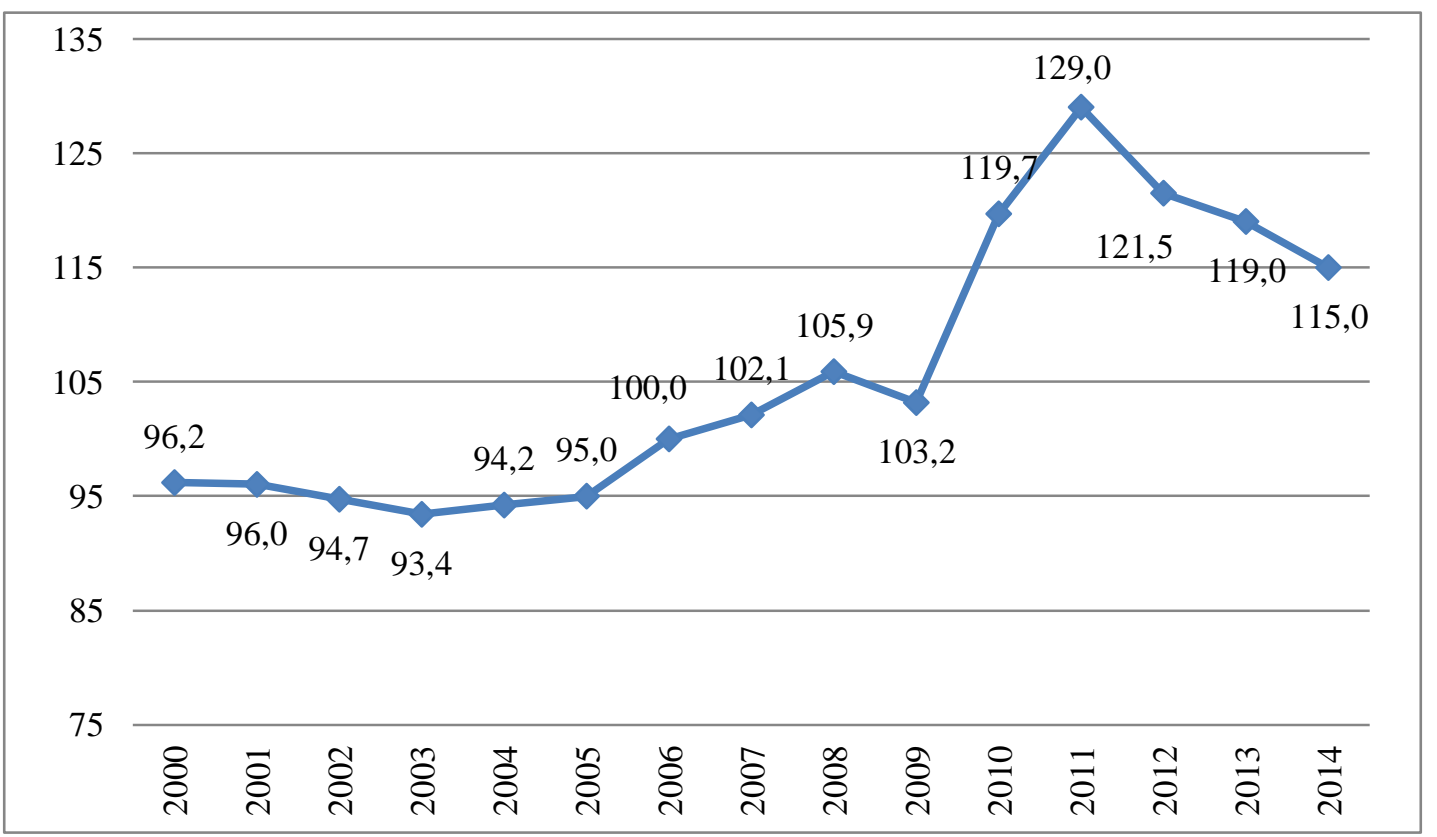

Fonte: elaboração própria a partir dos dados da FUNCEX.

Após muita instabilidade nos índices dos termos de troca na década de 1990 e com grande queda a partir de 1999, os termos de troca elevaram-se desde 2004 até 2008. No ano da crise de 2009 houve uma leve queda no índice de 105,9 para 103,2. A partir daí o Brasil experimentaria um grande crescimento do índice de termos de troca, com grande aumento em 2010 (119,7), e alcançando o seu ápice do período em análise em 2011 (129,0), ano em que superou o maior nível verificado em 1977, quando alcançou o índice de 127,9. O indicador apresentou queda contínua de a partir de 2011 121,5 em 2012, 119 em 2013, e 115 em 2014. Mesmo o declínio, o valor tem se situado ainda assim bem acima do verificado na década anterior.

Cabe destacar que essa melhoria nos termos de troca também favoreceu países como Austrália, África do Sul, Chile e Rússia, tradicionalmente exportadores de produtos primários e semimanufaturados (cf. OECD Data, 2015). Um dado apresentado pelo presidente do Banco Central australiano, Glenn Stevens, reforça essa mudança nos termos de troca favorecendo os exportadores de commodities: "cinco anos atrás (em 2006), uma carga de minério de ferro comprava 2.200 TVs de tela plana. Agora (em 2011), a mesma carga compra 22.000" (THE ECONOMIST, 2011b, tradução nossa). No entanto, o preço do mercado de commodities é muito mais volátil do que o do mercado de bens manufaturados. Soma-se a isso o fato de que esse choque de preço relativo pode não implicar uma mudança estrutural dos termos internacional de troca, 
mas apenas conjuntural. A redução no preço internacional das commodities e a redução do crescimento chinês podem acentuar a trajetória de queda nos termos de troca de países agroexportadores.

Quanto à análise da corrente comercial, o Brasil aumentou em grande medida $\mathrm{o}$ seu comércio internacional no século XXI, em grande parte pela pujança da produção do setor agropecuário brasileiro impulsionado pela mecanização do campo. De 2003 a 2008, houve um aumento anual contínuo da corrente comercial. Em 2009, entretanto, houve uma queda de mais de 50 bilhões de dólares do comércio brasileiro com outras nações, mas as importações tiveram uma queda em proporção maior do que as exportações, o que fez com que o País apresentasse um aumento positivo no saldo comercial de 24,8 bilhões em 2008 para 25,3 bilhões em 2009. Houve uma retomada da corrente comercial em 2010 e novamente um aumento em 2011.

Figura 9 - Balança comercial brasileira em US\$ bilhões

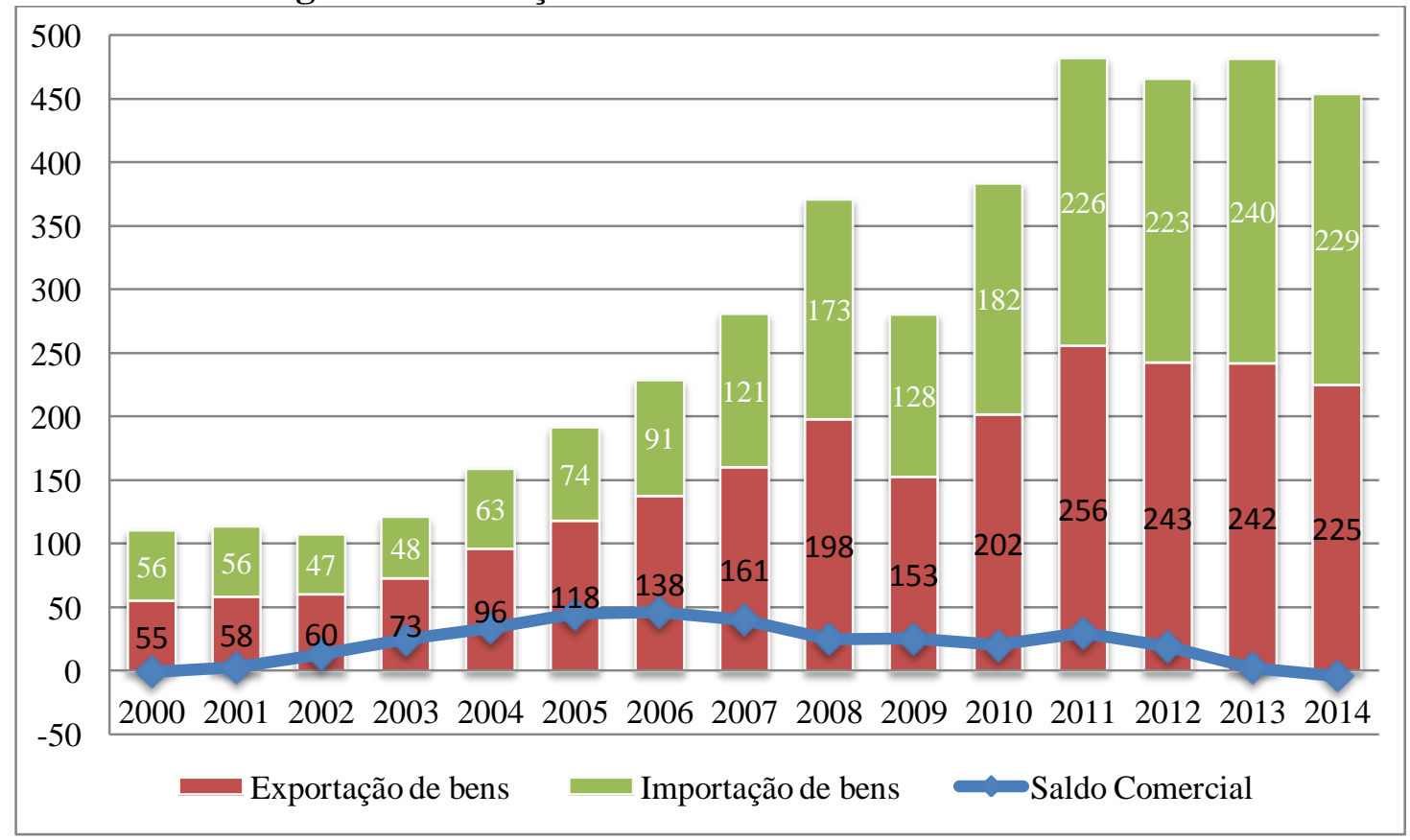

Fonte: elaboração própria a partir dos dados do Banco Central do Brasil - BCB.

Foi em 2011 que o Brasil atingiu o maior valor já exportado de algo em torno de 256 bilhões de dólares, exatamente quanto o índice dos termos de troca atingiram o nível mais favorável ao País até aqui no século XXI (129, conforme a figura 8). No entanto, o País não conseguiu retomar superar nem igualar a marca do valor das exportações de 2011 nos três anos seguintes. As exportações caíram para US\$ 243 bilhões em 2012, para U\$S 242 bilhões em 2013, e para US\$ 225 bilhões em 2014, acompanhando a queda do índice dos termos de troca do Brasil. 
De 2001 a 2006 o Brasil apresentou superávits elevados na balança comercial com crescimento anual contínuo, conforme figura abaixo. Foi no ano de 2006 que o País obteve o maior saldo comercial positivo até aqui no século XXI de US\$ 46,4 bilhões. Aumentou-se o ritmo de crescimento das importações brasileiras, que alcançaram o maior nível verificado no período 2000-2014 em 2013, com o valor de US\$ 240 bilhões. A valorização do real está por trás desse valor (conforme figura 14), visto que se aumentou o poder de compra da moeda brasileira, e tornaram mais caras as exportações do País.

A partir de 2007, o saldo comercial apresentou trajetória de queda, chegando ao valor de US\$24,8 bilhões em 2008, quase metade do valor verificado em 2006. O saldo voltaria a subir levemente em 2009, e voltar a cair em 2010. Em 2011, o saldo comercial apresentaria o valor mais positivo do período pós-crise. Entretanto, nos três anos seguintes, o saldo comercial positivo cairia drasticamente. Em 2012 o País obteve o menor superávit comercial desde 2002. Em 2013, houve uma queda ainda mais acentuada, sendo o menor saldo positivo desde 2001. Em 2014, depois de catorze anos, o Brasil voltaria a apresentar saldo comercial negativo, atingindo o valor de - 3,9 bilhões de dólares, sendo o menor valor desde 1998.

Figura 10 - Evolução do Saldo Comercial em Milhões US\$

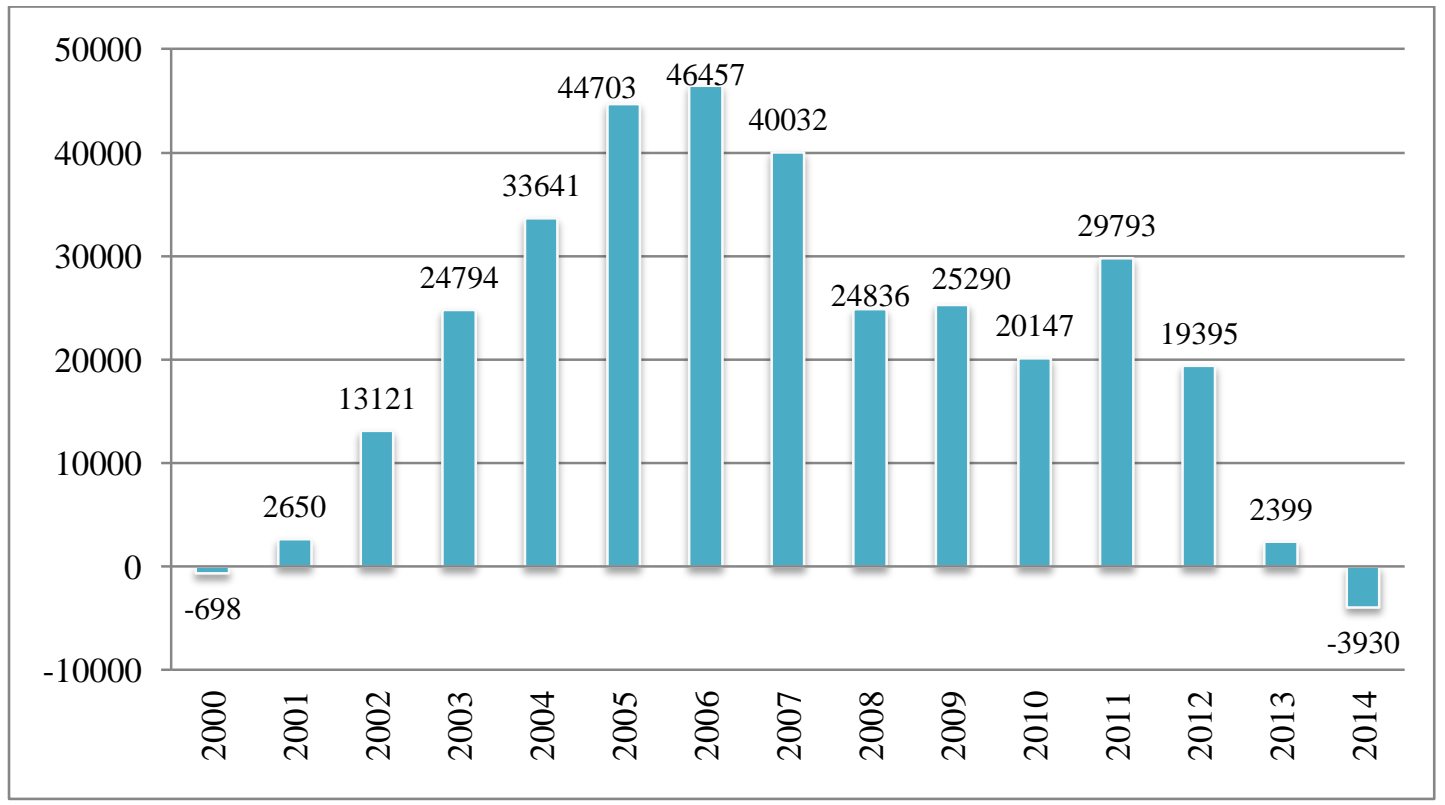

Fonte: elaboração própria a partir dos dados do Banco Central do Brasil - BCB.

Além da valorização do câmbio e do declínio do índice dos termos de troca do Brasil a partir de 2011, o modelo de desenvolvimento e proteção do mercado interno 
implicaram o saldo negativo na balança comercial brasileira. A demanda interna relevou-se muito superior à capacidade de oferta na indústria, o que prejudicou as exportações e a produtividade do setor (BACHA; BAUMGARTEM, 2013; BAUMANN, 2013). Diante desse cenário, as preocupações decorrem em grande parte da perda qualitativa da pauta exportadora brasileira no período, que, mesmo com os superávits verificados, desperta apreensões no que concerne a sustentabilidade futura dos ganhos comerciais. Parte das explicações decorre do descompasso da política industrial brasileira em relação ao seu tempo, e o grau de proteção do mercado interno no país.

No tocante ao resultado do balanço de pagamentos, o Brasil apresentou grandes superávits na conta de capital e financeira, o que fez com que o País experimentasse altos superávits entre 2006 e 2012, embora tenha apresentado uma grande queda para 3 bilhões de dólares no ano da crise de 2008. Como se verifica no gráfico abaixo (figura 12), houve um grande superávit no Balanço de Pagamentos do Brasil no ano de 2007 de algo em torno de 87 bilhões de dólares, o qual não foi recuperado no período pós-crise. Em 2011, o País alcançou seu segundo maior valor histórico de 59 bilhões de dólares. A partir de 2011, haveria uma grande queda nos resultados positivos do BP. Houve um retorno do déficit no BP no ano de 2013 de -6 bilhões de dólares, após mais de uma década de superávits, e muito distante dos valores dos anos anteriores.

Figura 11 - Resultado do balanço de pagamentos do Brasil em US\$ bilhões

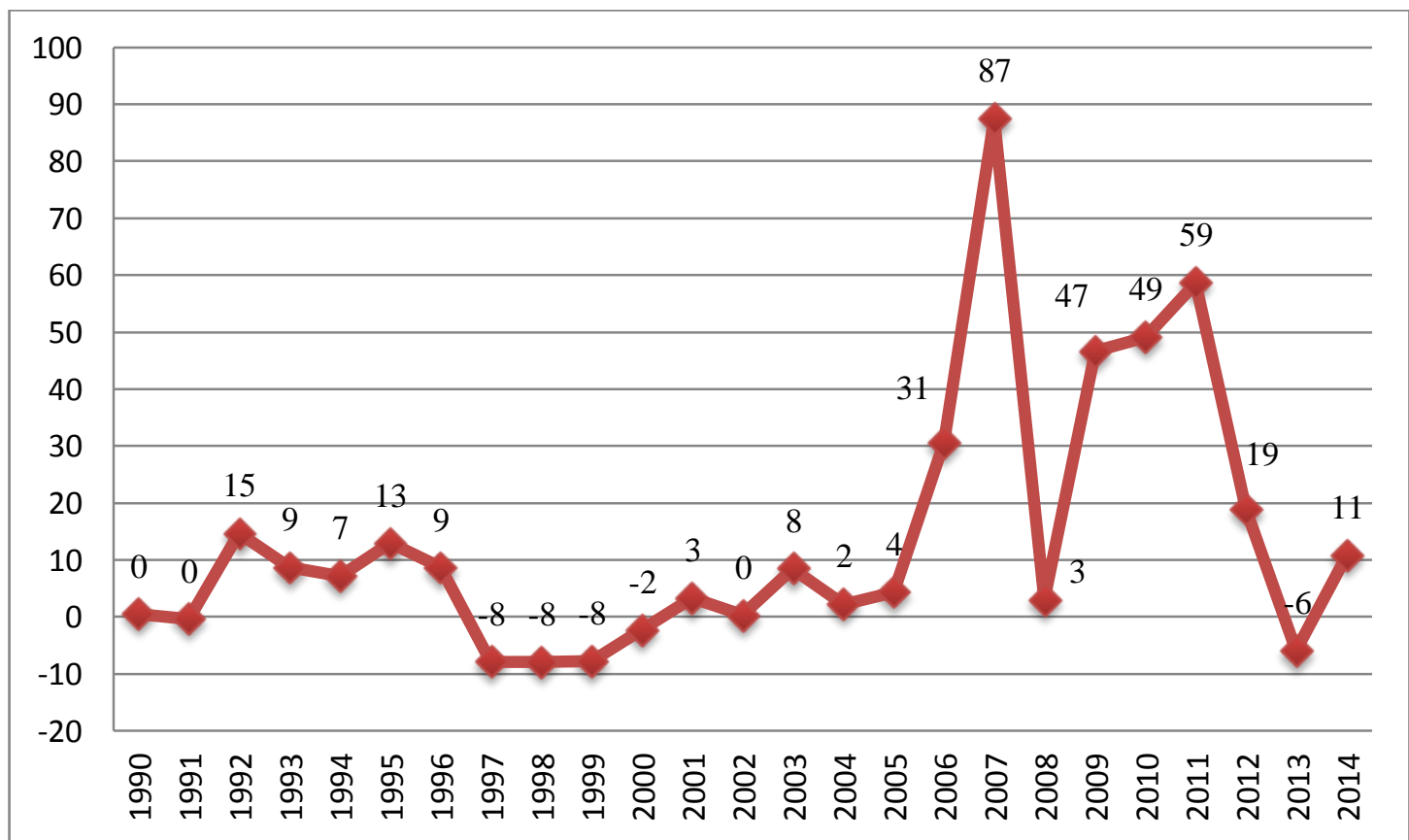

Fonte: elaboração própria a partir dos dados do Banco Central do Brasil - BCB. 
É possível apreender diante dos dados quantitativos apresentados que a economia brasileira foi beneficiada por um cenário externo muito favorável pelo menos entre 2004 e 2011, período em que o destaque dado ao Brasil como grande potência se acentuou. As baixas taxas de juros internacionais, a entrada paradoxal de IEDs, e os termos de troca favoráveis ao Brasil somam-se aos resultados de reformas realizadas no País na década de 1990 e primeiro mandato do governo Lula (como a estabilidade macroeconômica decorrente do Plano Real, o que garantiu maior previsibilidade aos agentes econômicos nacionais) para produzir um cenário propício e facilitado ao crescimento nacional.

Entretanto, o Brasil pode ter se acomodado aos fluxos do período, e para o seu crescimento sustentado o País demandaria reformas pró-produtividade que não realizou (GIAMBIAGI; SCHWARTZMAN, 2014). A redução dos preços das commodities e o possível aumento das taxas de juros nos EUA podem implicar o fim de um ciclo de bonança externa ao Brasil. O momento não foi desperdiçado por completo, visto que o país soube aproveitar os influxos para o fomento do crescimento. O problema é que reformas importantes para ganhos de competitividade econômica brasileira, as quais garantiriam um crescimento mais sustentado e próspero, não foram realizadas quando o momento era mais propício. Trata-se mais uma vez de uma espécie de path dependence quanto às decisões políticas que uma vez tomadas influiriam significativamente a inserção econômica do Brasil na economia global. A primarização da pauta exportadora brasileira é um dos resultados preocupantes dos últimos anos.

\subsection{A Primarização da Pauta Exportadora Brasileira}

Apesar de ter ocorrido um grande aumento da corrente comercial em decorrência do crescimento do próprio país e mundo emergente de 2003 até a crise de 2008/2009, ocorreu uma elevação significativa do setor primário na pauta brasileira de exportações no período 2003/2013. O gráfico abaixo elaborado pela Secretaria de Comércio Exterior do Ministério de Desenvolvimento, Indústria e Comércio Exterior (SECEX) mostra a composição da pauta de exportação brasileira por fator agregado de 1964 a 2013. 
Figura 12 - Exportação brasileira por fator Agregado de1964 a 2013 Participação \%

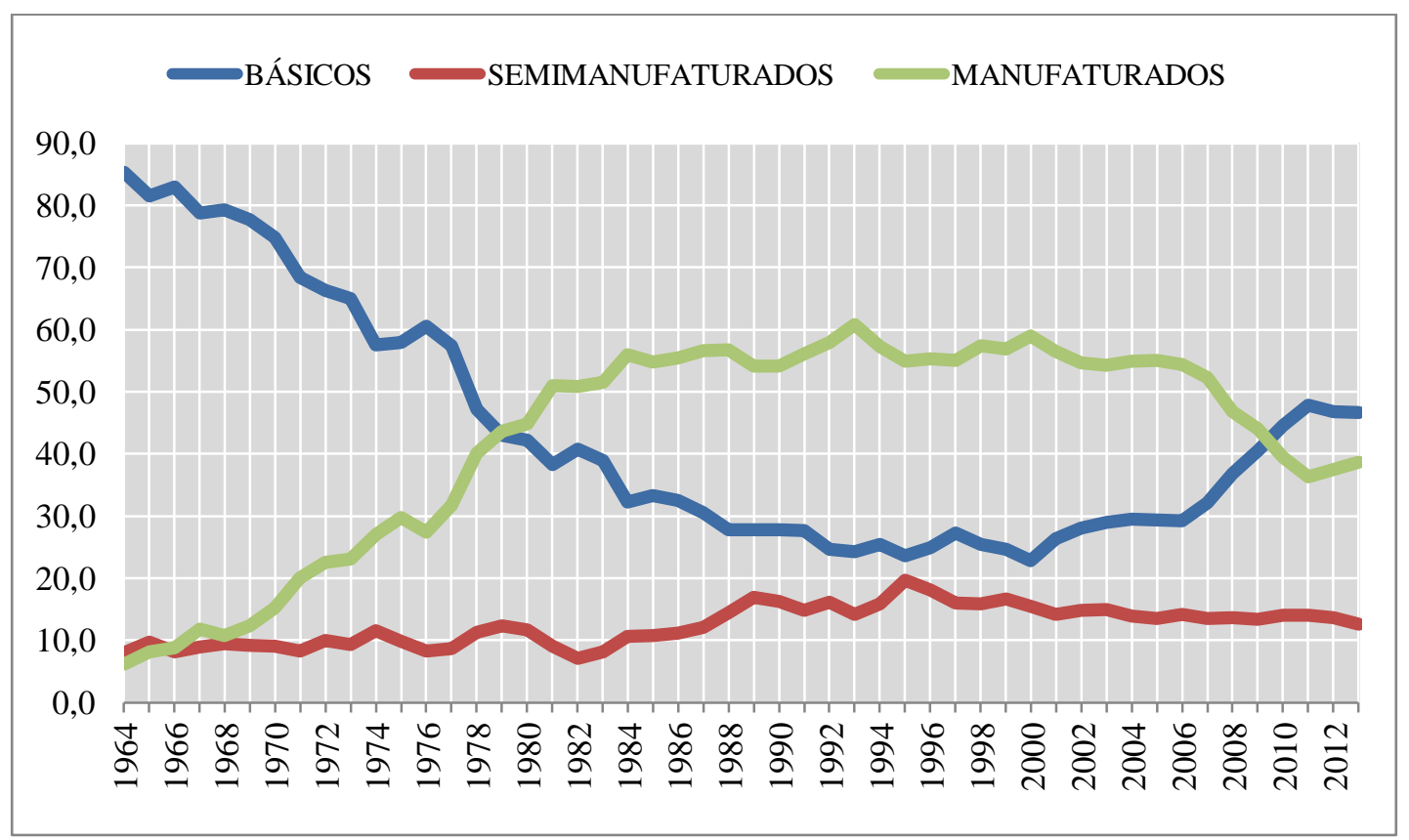

Fonte: Secex/MDIC.

Em meados da década 1980, o Brasil conseguiu reverter o padrão da composição da pauta das décadas anteriores, e o país passou a exportar mais produtos manufaturados do que produtos básicos. Segundo o professor Gabriel Palma, "[e]m 1980, a produção industrial no Brasil era maior do que a da Tailândia, Malásia, Coreia do Sul, Índia e China juntos. Trinta anos depois, representava apenas $10 \%$ do total produzido por esses países" (PALMA, 2013). Esse padrão teve continuidade em boa parte da década de 1990. No ano de 1990, a pauta exportadora do Brasil era composta por 27,8\% de produtos básicos, 16,3\% de semimanufaturados, e 54,2\% de manufaturados. Em 1995, o país teve um aumento dos semimanufaturados que passaram a responder por $19,7 \%$ da pauta exportadora, enquanto os itens básicos respondiam por $23,6 \%$ e os manufaturados por $55 \%$. No ano 2000, elevou-se a composição de manufaturados na pauta para $59 \%$, reduzindo a de produtos básicos para 22,8\% e de semimanufaturados para 15,4\%.

Contudo, no início dos anos 2000, devido aos fatores já mencionados, os produtos básicos ganharam participação na pauta, enquanto os produtos manufaturados perderam participação. Em 2005, os produtos básicos representavam 29,3\% da pauta, os semimanufaturados $13,5 \%$ e os manufaturados 55,1\%. A partir daí, o processo de primarização acelerou-se. Em 2010, a pauta brasileira passou a ter uma maior porcentagem de participação das commodities no mesmo nível do final dos anos 1970, ano em que produtos básicos constituíram $44,6 \%$ da pauta, os semimanufaturados $14 \%$, 
e os manufaturados 39,4\%. No último no disponível pela Secex, em 2013, os produtos básicos respondiam por $46,7 \%$ da pauta, enquanto os semimanufaturados por $12,6 \%$ e os manufaturados por $38,7 \%$. Esse efeito tem alimentado um debate brasileiro sobre a hipótese de desindustrialização do Brasil e déficit de competitividade sistêmica da indústria brasileira, de forma comparada, inclusive, com demais países emergentes (BACHA; BAUMGARTEN, 2013; BAUMANN, 2013b; CNI, 2015; WEF, 2014).

O choque de preços relativos em termos globais dos bens manufaturados e commodities contribuíram para essa mudança na pauta de exportações do Brasil. Para Canuto (2014a, p. 41), o maior grau de intensidade no uso do fator trabalho reduziram os preços de bens industriais intensivos em mão de obra; enquanto que a expansão da demanda decorrente de países emergentes - de transição da renda baixa para a renda média - por sua vez provocou um aumento dos preços dos produtos intensivos em recursos naturais. Cabe enfatizar esse aspecto a fim de evitar um "erro de percepção" por parte do governo brasileiro. A reversão dos termos de troca do Brasil da primeira década do século XXI não foi resultado de inovações brasileiras per se ou de aumento da produtividade nacional, mas de fatores exógenos como demonstrado na seção anterior. De acordo com Baumann (2014a, p. 47-48), ao analisar a variação de preços dos itens da pauta exportadora do Brasil, entre 2000 e 2013, o aumento dos preços das exportações de bens primários foi da ordem de $196 \%$, enquanto que no caso dos bens manufaturados foi de $77 \%$, resultando na duplicação do volume abarcado no primeiro, e aumento do volume de 65\% no segundo. (BAUMANN, 2014a, p. 47-48).

Cabe enfatizar que o processo atual apresenta certas similaridades com a hipótese da "inserção regressiva" do Brasil no sistema mundial de comércio, tal como proposto pelo economista Reinaldo Gonçalves em 2001. Para o autor, esse processo "envolve tanto a significativa perda de competitividade internacional da indústria brasileira, quanto o fenômeno da primarização da pauta exportadora" (p.1). Contudo, na segunda metade da década de 1990, essa "inserção regressiva" era acompanhada por um período de reformas, com um aumento da produtividade econômica nacional via modernização do aparelho produtivo e abertura comercial. Além disso, em boa parte da década de 1990 os bens intensivos em recursos naturais passavam por uma evolução negativa dos preços, além de estarem sob influência negativa da taxa de câmbio e capacidade de investimento (GONÇALVES, 2001). Entretanto, a situação revertida na primeira década e meia do século XXI apresentaria dificuldades maiores para a obtenção de melhorias da produtividade econômica. Conforme estudo da CNI, 
comparado com países com os quais o Brasil compete de forma mais clara no comércio internacional, o País ainda carece de qualidade na infraestrutura e disponibilidade de capital (Conf. CNI, 2015). Além disso, as restrições às importações de bens intermediários e de capital revelaram-se bem mais altas comparadas à maioria dos demais países emergentes ${ }^{28}$.

O "efeito chinês" nas exportações brasileiras torna-se mais claro perante a observação da evolução da posição do país como maior parceiro comercial do Brasil. A grande ascensão da China, de fato, deu-se no século XXI, pois sua economia alcançou o seu primeiro trilhão em termos de PIB em dólares correntes apenas em 1998, um ano antes do Brasil alcançar o mesmo feito. Não somente como comprador das exportações brasileiras a China se destacou no século XXI como parceiro comercial de grande relevância para a economia brasileira, mas como Estado de origem das importações de manufaturados do Brasil.

De acordo com dados da SECEX, em 2001 a China ocupava apenas o $12^{\circ}$ lugar de origem das importações brasileiras, ano em que ingressou na OMC. Em 2002, o país era $8^{\circ}$ parceiro no mesmo quesito. Em 2003, já ocupava a $5^{\text {a }}$ colocação, sendo $3^{\circ} \mathrm{em}$ 2005 e $2^{\circ}$ em 2006. Em 2010, a China tornou-se o principal parceiro de origem das importações do Brasil, superando os Estados Unidos, colocação a qual mantém desde então, com maior fluxo de bens manufaturados (SECEX, 2015). Como a pauta das exportações brasileiras destinadas à China contém uma maior concentração commodities do que manufaturados, cabe ao Brasil saber lidar com o comércio bilateral de forma a aproveitar os influxos comerciais e financeiros para o desenvolvimento nacional, e ao mesmo tempo, não fazer desses mesmos influxos uma "quimera externa" de forma que possa acelerar a primarização da pauta exportadora do País. A mudança do perfil das exportações brasileiras, ensejada em boa parte pela demanda chinesa por commodities, aumenta a necessidade de "diversificação, aprendizagem tecnológica e upgrading da indústria", elevando o seu conteúdo tecnológico (STURGEON, et al., 2013). Para isso, a inserção qualitativa nas cadeias globais e regionais de valor serve ao propósito da sustentabilidade e aumento da competitividade do parque industrial.

Uma série de analistas tem corroborado a hipótese de que o crescimento chinês e o boom das commodities foram essenciais para o crescimento econômico brasileiro da primeira década do século XXI: Edmar Bacha (2014), José Mendonça de Barros

\footnotetext{
${ }^{28}$ Esse ponto será tratado com maior detalhe no capítulo 4, ao tratarmos da distorcida estrutura de proteção tarifária no Brasil.
} 
$(2014)^{29}$, Renato Baumann (2013b), Roberto Abdenur (2014), Sean Burges (2013) ${ }^{30}$, e Jim O'Neill (2014), criador do termo BRIC em 2001. O 'Neil destaca em artigo que questiona a queda do crescimento do BRICs ${ }^{31}$, de que Brasil e Rússia deveriam procurar reduzir sua dependência em relação ao ciclo de commodities, com criação de maior espaço para o empreendedorismo e aumento dos investimentos privados (O'NEILL, 2014).

Evitar uma dependência de um mercado tão volátil como o das commodities - o qual gera menos externalidades relacionadas ao progresso técnico como o setor industrial gera, devido ao baixo grau de transformação naquele - torna-se demasiadamente importante no contexto de uma sociedade como a brasileira em que há uma demanda generalizada para o aumento dos níveis de qualidade educacional. Entretanto, a competitividade industrial está cada vez atrelada ao contexto de fragmentação e dispersão da produção internacional, e a concorrência tem sido cada vez mais acirrada na medida em que outros países se inserem de forma mais efetiva às cadeias globais de valor, e oferecem melhores condições para atração de investimentos estrangeiros (BALDIWN, 2011; ELMS; LOW, 2013; STURGEON, et al., 2014).

Para Sharma (2012), o Brasil deve procurar alternativas de política para reduzir a dependência do ciclo de commodities e adotar uma abertura comercial a fim de revitalizar o aparato industrial: "[t] o avoid falling behind, Brasília needs to take risks and open up the economy (...). Ending that protectionism could bring competition to Brazilian factories, while also lowering the value of the real, creating the opportunity for a revival in manufacturing". Maiores investimentos em educação, em Pesquisa e

\footnotetext{
${ }^{29}$ De acordo com José Mendonça de Barros, haveria um descompasso com a respostas brasileiras aos novos desafios do crescimento: "O governo insiste em uma medicação para uma doença que mudou, o cenário é outro agora e nós não temos a China crescendo a $12 \%$, não temos, e nem teremos, um crescimento acelerado da demanda interna porque o grande efeito da inclusão já passou e as famílias estão endividadas", afirmou o economista no dia 02/06/14 em reunião do Conselho Superior do Agronegócio (Cosag) da FIESP (FIESP NOTÍCIAS, 2014).

${ }^{30}$ Burges (2013) ainda relata outro fator complicador para a conscientização desse efeito, o da baixa percepção das famílias brasileiras sobre ele: "A última década deixou claro que existe um vínculo direto entre o aumento dos preços das commodities e o crescimento econômico geral brasileiro. Mas esse vínculo não é necessariamente sentido de forma óbvia pela maioria das famílias brasileiras. Grandes alterações nos preços das commodities ou negociações sobre as regulamentações fitossanitárias podem parecer pouco importantes para pessoas que trabalham em serviços domésticos ou em setores manufatureiros".

${ }^{31}$ A situação de Brasil e Rússia apresentam similaridades na dependência do ciclo das commodities. Segundo O'NEIL: "I do believe each of Brazil and Russia have got some challenges to face, that they are not yet confronting, which at the core is to reduce their dependency to the commodity cycle, and while there are many differences between them, they do both need to become more competitive and entrepreneurial outside of commodities and to boost private sector investment" (O'NEIL, 2014).
} 
Desenvolvimento e em projetos de infraestrutura também são recomendados por diversos analistas para o crescimento sustentado brasileiro.

Em entrevista ao Jornal Brasil Econômico, Baumann (2014b) destaca quatro momentos de políticas na história recente brasileira no que tange ao incentivo à exportação do setor industrial brasileiro. Na década de 1980, os governos brasileiros adotaram uma ênfase nas exportações na agenda de política industrial. Diante das dificuldades macroeconômicas - muitas delas decorrentes da hiperinflação resultante dos gastos públicos excessivos -, na década de 1990, em especial, no início da implantação do Plano Real, havia uma percepção de que os "incentivos ao setor exportador era transferência de renda real a um grupo de empresas privilegiadas" (BAUMANN, 2014b). Após 1997, com a crise asiática, a política cambial adotada passou a incentivar as exportações, mesmo que dentro de uma margem menor de atuação política em virtude das normas impostas pela OMC.

Já no governo Lula, conforme Baumann, a ênfase foi dada ao mercado interno, com a economia se beneficiando de um cenário externo muito favorável, com alta dos preços das commodities e influxos de capitais estrangeiros. Como resultado dessa política, houve uma entrada de divisas, e em decorrência, a apreciação do Real, o que aumentou os custos de produção do setor industrial. Esse efeito enseja argumentos em prol de uma doença holandesa no Brasil, da qual, tornar-se ainda mais complexa com os novos padrões de comércio internacional: "Para sermos um produtor de manufaturas que sobreviva de forma competitiva, é preciso exportar, ser competitivo lá fora. E para fazer isso, o nome do jogo hoje é cadeia de valor. " (BAUMANN, 2014b).

Adicionalmente aos elementos analisados, o câmbio depreciado nos primeiros anos do início do século XXI foi um fator complicador para a contenção de pressões inflacionárias no final do governo Fernando Henrique. Conforme a figura 14, houve um comportamento benigno da taxa de câmbio nominal, a qual passou uma valorização contínua até o período compreendido entre 2008 e 2009, e voltou a valorizar-se até o início do governo Dilma em 2011. A partir daí, houve uma tentativa de reversão do processo, e a desaceleração da economia brasileira provocou uma valorização do dólar frente ao real. 
Figura 13 - Taxa de câmbio R\$/US\$ média entre compra e venda de 13.1.1999 até 13.02.2015

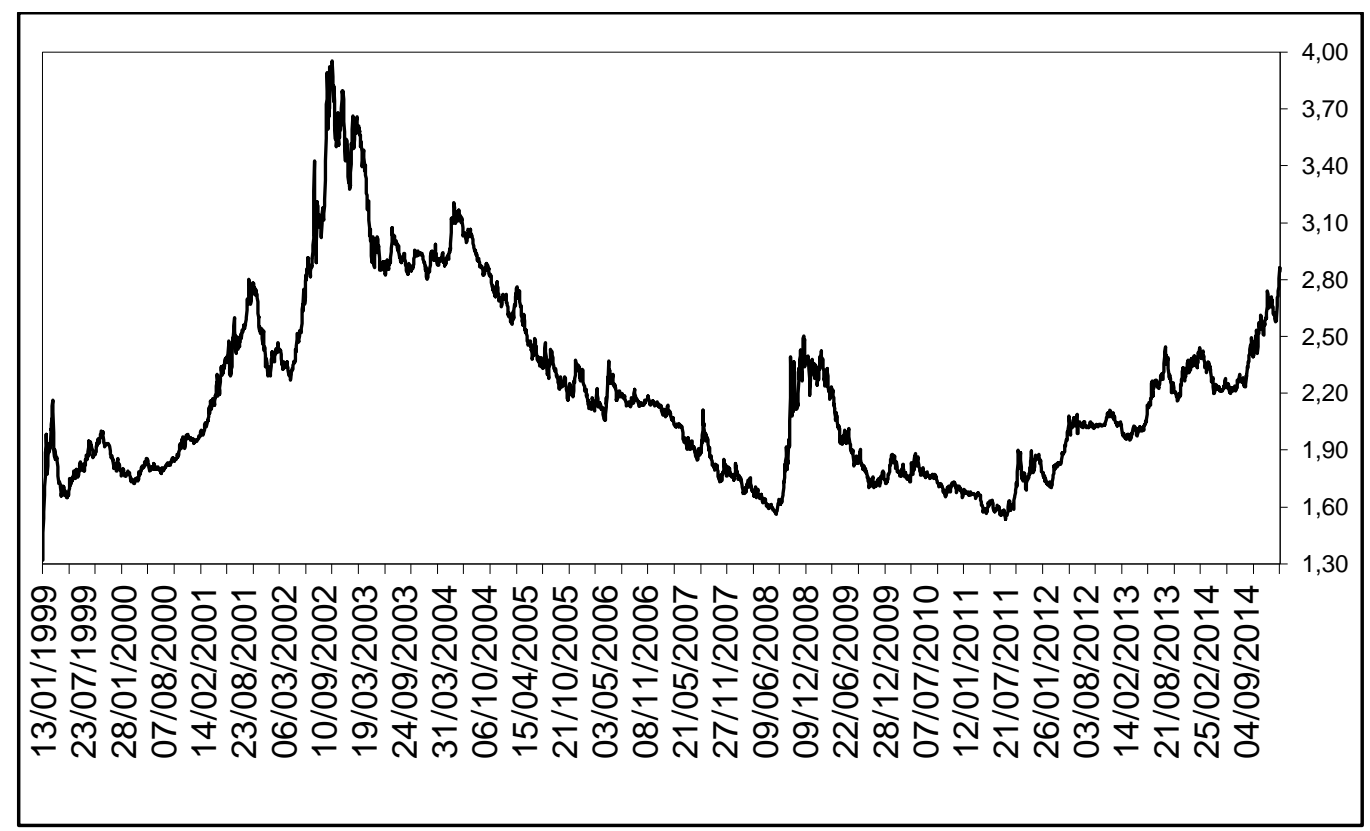

Fonte: Banco Central do Brasil - BC.

O retorno da valorização da taxa de câmbio no Brasil provoca um efeito dúbio nas exportações brasileiras. Por um lado as exportações tornam-se mais competitivas em termos de preço com a desvalorização da moeda nacional. Por outro, muitos setores de alto valor agregado que demandam importações de bens, como o de eletrônicos, podem repassar o maior custo de produção para os preços, prejudicando não somente as exportações como impactando negativamente a política anti-inflacionária.

\subsection{As Políticas Industriais no Brasil no Século XXI e Seus Questionamentos}

As políticas industriais, em especial, de conteúdo manufaturado e tecnológico voltaram à moda no século XXI (RODRIK, 2010). Essas políticas são utilizadas como estratégias de fomento da indústria nacional e tentativa de criação ou proteção de empregos, seja com intervenção na alocação de recursos e fatores na economia ou industrialização via importações de insumos a baixo custo, por exemplo.

Há duas justificativas centrais para envidar-se esforços para impulsionar a indústria nacional. A falência de empresas possui custos sociais elevados, além de implicarem em custos de ajuste em termos de qualificação de trabalhadores. para que estes possam se reinserir em outros setores do mercado de trabalho. O segundo é 
explorado e defendido por Stiglitz e Greenwald na obra Creating a Learning Society (2014), de que a indústria possui externalidades positivas quanto ao aprendizado, conhecimento e capacitação técnica para o restante da economia e sociedade nacional. Esse fator possui uma importância fundamental para a sociedade brasileira, em que se verificam baixos índices educacionais ${ }^{32}$. Além disso, não é apenas a diferença de dotação de recursos que explica a distância em termos de desenvolvimento entre países ricos, emergentes e pobres, mas também a diferença de níveis de conhecimento e aprendizagem tecnológica. Em virtude desse e outros fatores, como a própria inclusão social, que o setor industrial tornar-se particularmente importante para os países emergentes e pobres.

Para os autores, um pouco distintamente de nossa visão, a intervenção governamental possui importância basilar para a criação de uma sociedade do aprendizado, tanto em matéria de política industrial quanto comercial. Em um ponto concordamos com os autores: quanto mais monopolizado um setor estiver, mais "internalizada" e menos "externalizada" estará a capacidade de aprendizado ${ }^{33}$. Cabe ao governo evitar a monopolização de setores econômicos (STIGLTIZ; GREENWALD, 2014), algo que é compartilhado inclusive por economistas mais ortodoxos. Ainda segundo Stiglitz e Greenwald (2014), as políticas industriais são inevitáveis, e de uma forma ou de outra, o governo está envolvido em alguma política industrial, seja por intervenção direta na alocação de recursos setoriais, ou mesmo por meio de instituições, regras e regulamentos que influem sobre o comportamento de agentes privados.

No Brasil, o Ministério do Desenvolvimento, Indústria e Comércio Exterior (MDIC) é o principal órgão responsável pela elaboração da política industrial do Brasil. Criada em 2004 pelo governo federal brasileiro, a Agência Brasileira de Desenvolvimento Industrial (ABDI), ligada ao MDIC, é responsável pela articulação, coordenação, promoção e execução da política industrial do país. A ABDI tem como missão "desenvolver ações estratégicas para a Política Industrial, promovendo o

\footnotetext{
${ }^{32}$ Exemplo disso são os últimos resultados do teste internacional PISA, no qual o Brasil tem obtido notas abaixo não só dos países da OCDE, mas também em relação à média latino-americana.

33 Apesar dos benefícios do comércio livre e das economias de escala, tais efeitos se aplicam em maior parte em condição de concorrência perfeita. A maioria dos mercados na economia incluem elementos de livre concorrência e de monopólio. Segundo Mankiw, a empresa típica na economia enfrenta a concorrência, mas a concorrência não é tão rigorosa quanto a tornar a empresa um tomador de preço. A empresa típica tem também um certo grau de poder de mercado, mas seu poder de mercado não é tão grande que a empresa possa ser descrita exatamente pelo modelo de monopólio. Em outras palavras, muitas indústrias encontram-se entre os casos polares de concorrência perfeita e monopólio. Os economistas chamam essa situação de concorrência imperfeita (MANKIW, 2012, p. 330).
} 
investimento produtivo, o emprego, a inovação e a competitividade da indústria brasileira", e adota a visão de "referência na articulação público-privada e em inteligência industrial para promoção do emprego, da inovação e transformação da indústria brasileira" (Site ABDI, 2015).

A Agência destaca em seu site ${ }^{34}$ três momentos da política industrial do Brasil durante a administração do Partido dos Trabalhadores (PT). O primeiro, diz respeito à Política Industrial, Tecnológica e de Comércio Exterior (PITCE) executada no período 2004-2008, a qual "teve como pilar central a inovação e a agregação de valor aos processos, produtos e serviços da indústria nacional" (Site ABDI). Seguiu-se a Política de Desenvolvimento Produtivo (PDP), executada no segundo governo Lula entre 2008 e 2010 em um momento de crise internacional, sob a qual o governo executou uma espécie de papel de promotora de políticas macroeconômicas anticíclicas (KUPFER, 2013), desvirtuando-se em parte dos objetivos traçados.

O governo Dilma lançaria a terceira política industrial brasileira denominada "Plano Brasil Maior" (PBM), executada entre os anos 2011 e 2014, a qual possuía como um de seus objetivos norteadores o adensamento de atividades de alta produtividade e tecnologia das cadeias de valor, sem fazer explícita referência a qual amplitude geográfica é esse cadeia (regional, global ou nacional). Para Kupfer (2013), esse objetivo foi frustrado devido ao acirramento da concorrência internacional verificado no período tanto no mercado interno quanto externo, o que "forçou o plano a se direcionar para a defesa do mercado doméstico e a recuperação das condições sistêmicas da competitividade, com foco mais diretamente nos fatores formadores do custo-país e menos nas ações estruturantes de seus programas setoriais" (KUPFER, 2013, grifo nosso). Ainda segundo o professor, "a política industrial brasileira ainda não se mostrou capaz de pensar à frente de seu tempo, sendo sempre surpreendida por rupturas no seu diagnóstico de base" (KUPFER, 2013). Sturgeon et al (2013), também contestam a efetividade do Plano Brasil Maior implementado no governo Dilma. Para os autores, "as políticas industriais do Brasil carecem de objetivos coerentes (...) pouco se faz para identificar e incentivar o crescimento em nichos específicos das CGVs nos quais o Brasil tem uma vantagem competitiva", os autores sugerem a concentração de esforços por parte dos formuladores de políticas nos " nichos específicos de alto valor nas CGVs em que o Brasil possa ser competitivo" (STURGEON et al. 2013, p. 37).

34 ABDI. Política Industrial. Agência Brasileira de Desenvolvimento Industrial. Disponível em: <http://www.abdi.com.br/Paginas/politica_industrial. aspx>. Acesso em: 30 jan. 2015. 
Diante desse quadro, percebe-se que não há uma clareza quanto à percepção de mundo do Brasil de modo que possa acompanhar as transformações em curso da economia global, como a evolução das Cadeias globais de valor, as quais não possuem referência explícita nos três programas de política industrial, tampouco termos similares como a "fragmentação e dispersão da produção", offshore e outsourcing. A opção por um aumento da produtividade via concorrência e liberalização comercial não parece ser uma opção viável ou considerada para a implementação de políticas industriais no período do governo Dilma, e em especial, após 2006, com a chegada de Guido Mantega ao Ministério da Fazenda. A defesa do mercado doméstico, as regras de conteúdo local, e o fomento de setores via intervenção governamental, parece ser uma constante no Brasil desde 2003, em especial, no período pós-crise de 2008/2009.

A política industrial brasileira tem despertado críticas quanto aos seus impactos que distorceriam o comércio internacional e as condições de concorrência. Apesar de estar em negociação desde 1999 o acordo entre União Europeia e Mercosul, a UE acionou o Brasil na OMC em outubro de 2014 contra os incentivos industriais brasileiros, devido ao seu caráter protecionista e discriminatório. Para Jamil Chade (2015), "trata-se do maior questionamento já aberto contra as regras de investimento do setor produtivo brasileiro, base da política industrial do governo da presidenta Dilma Rousseff".

A UE também questiona o condicionamento para os benefícios fiscais por parte do governo brasileiro do uso de componentes locais na indústria nacional, portanto, sendo esta uma forma de substituição de importações (CHADE, 2015). Esse questionamento é mais abrangente do que o realizado nos contenciosos em torno da concorrência entre a Embraer e Bombardier ao redor da virada do século, nos quais os canadenses questionavam as ações do Programa de Financiamento das Exportações (PROEX) realizado pelo Brasil, as quais supostamente não estariam de acordo com as determinações da OMC. Para Bonomo, caso o questionamento europeu seja bem sucedido, principalmente caso decida pela abertura de um painel contra o Brasil, o País virá a ser obrigado a adotar reformas em matéria de política industrial e comercial, "sobretudo no uso de requisitos de conteúdo local e tributação favorecida" (BONOMO, 2014, p. 6).

Em seu Relatório Anual de 2014, a OMC declarou que seus Estados-membros expressaram uma preocupação com os instrumentos utilizados pelo Brasil em sua política industrial, como o "aumento de taxas indiretas para proteger e promover a 
produção industrial doméstica, particularmente pelo uso de condicionamentos de conteúdo local", a exemplo da política aplicada no setor automobilístico e de fertilizantes (WTO, 2014, p. 45) ${ }^{35}$.

A indústria de transformação do Brasil tem perdido competitividade tanto no plano interno quanto no externo, indicando como a economia global interdependente torna o "choque externo" inevitável. A elevação do nível de consumo interno, a valorização cambial do real frente ao dólar, e a menor capacidade de oferta da indústria doméstica estimularam as importações - muitas delas, de menor preço e maior qualidade -, intensificando (mesmo que não seja de forma incisiva) a concorrência para os produtos do mercado interno brasileiro. No plano externo, especialmente o regional, o Brasil tem perdido preferências tarifárias em mercados tradicionais para as manufaturas brasileiras, como nos Estados Unidos, México e Chile, que firmaram um grande número de acordos de preferências comerciais ao longo das últimas décadas (BAUMANN, 2013b; ZANOTTO, 2014, p. 9; THORSTENSEN; FERRAZ, 2014). O Brasil apresenta políticas nos últimos anos de orientação contrária à participação nos novos padrões de comércio e novos desafios de competitividade comercial relacionados ao "comércio de valor agregado", no qual os países estariam "empenhados em capturar os maiores seguimentos de valor das CGV não só para aumentar suas exportações totais, mas também para garantir às empresas locais acesso a insumos de padrão mundial" (STURGEON et al., 2014, p. 161).

Sturgeon, Gereffi, Guinn e Zylberberg realizaram um estudo sobre a indústria brasileira e as cadeias globais de valor em 2014, encomendado pela CNI (2014), e apresentaram as dificuldades de inserção da economia brasileira no comércio internacional. Dentre os desafios políticos e econômicos apresentados pelos autores, destacam-se: (1) "a complexidade e instabilidade do regime de política industrial do Brasil geram dificuldades para as empresas desenvolverem projeções adequadas"; (2) "as Pequenas e Médias empresas (PME) do Brasil têm dificuldades para acessar cadeias globais de valor"; (3) "os custos adicionais necessários para manter as atividades no Brasil (alto custo - Brasil)"; (4) "alguns objetivos de desenvolvimento do Brasil podem ser irrealistas", tais como "esforços persistentes para promover indústrias nacionais

\footnotetext{
35 "WTO members expressed concern at the increased use by Brazil of indirect taxes to protect and promote domestic manufacturing, particularly through the use of domestic content conditions. These have been extended beyond automobiles to other sectors, such as the fertilizer sector". WTO. Annual Report 2014. Disponível em: https://www.wto.org/english/res_e/booksp_e/anrep_e/anrep14_e.pdf: Acesso em: 28 fev. 2015.
} 
completas e plenamente integradas verticalmente"; (5) "as políticas de promoção de exportações adotadas pelo Brasil são inconsistentes e relativamente fracas"; (6) "as políticas de substituição de importações do Brasil devem ser mais flexíveis"; e, (7) a existência de "uma relação ambivalente com empresas multinacionais na economia brasileira", as quais "tendem a ser vistas principalmente como fontes de investimentos e receitas fiscais e não de tecnologias, empregos, exportações e vinculações à CGV" (STURGEON, et al., 2014, p. 6 - 10).

É possível deduzir que os desafios apresentados não estão vinculados a fatores exógenos ao Brasil, mas sim de opções de políticas adotadas ou mesmo de uma visão de mundo que não está em consonância com uma inserção efetiva e qualitativa nos novos padrões de comércio internacional. O governo brasileiro parece ter adotado políticas em sentido contrário ao pensamento interdependente de Rosecrance (1999), na medida em que aplicaram regras de conteúdo local para a indústria, e elevaram as barreiras comerciais tarifárias para bens intermediários que poderiam ser utilizados como componentes de exportações finais de maior conteúdo tecnológico (ABREU, 2007; PEREIRA, L. 2013).

\subsection{A Formação Bruta de Capital Fixo como Diferencial de Competitividade}

As condições da infraestrutura brasileira, portos, aeroportos, estradas, capacidade inovadora, entre outras, frequentemente são caracterizadas como deficientes e onerosas à economia nacional. De fato, essas condições fazem parte de um conjunto de elementos que prejudicam o grau de competitividade da indústria brasileira no comércio internacional, ou mesmo, comércio interno com as importações, configurando-se como fatores de limitações pelo lado da oferta da competitividade. (GONÇALVES, 2001).

Um aspecto importante no que concerne ao aumento da competitividade da estrutura econômica nacional para uma inserção mais aprimorada no cenário internacional é a formação bruta de capital fixo (FBCF), indicador que mede o quanto foi produzido por empresas no país, "bens de capital", como máquinas, equipamentos, materiais de construção, que servem para a produção de outros bens (WOLFFENBÜTTEL, 2004). Esse indicador é de vital importância para determinar a capacidade produtiva do país, além de ser considerada a base para o crescimento de 
longo prazo e sustentado. Entretanto, a taxa de investimento depende diretamente da taxa de poupança do país, historicamente baixa.

Dentre uma série de países emergentes analisados (China, Coreia do Sul, Índia, Indonésia, Arábia Saudita, Colômbia, México, Rússia, Turquia, África do Sul, Argentina e Brasil), o Brasil foi o último colocado na média de formação bruta de capital fixo no período compreendido entre os anos 2003 e 2013 (último ano disponível pelo Banco Mundial). O capital fixo é considerado a base para o crescimento, e envolve uma gama de incentivos econômicos e aos investimentos produtivos de longo prazo, ao reduzir os déficits de infraestrutura, melhoria nas zonas portuárias, e maquinários que aumentam a produtividade da economia e ajudam consideravelmente na redução dos custos de produção. O custo Brasil é um fator limitador da integração da economia nacional na economia global, bem como para as exportações de empresas brasileiras e inserção efetiva nas Cadeias Globais de Valor. Enquanto isso, a integração de China e Coreia do Sul nas CGVs ajudou a aumentar a sua base para o crescimento, e destinam mais de $30 \%$ de seu PIB à formação bruta de capital fixo na média dos 10 anos analisados.

Tabela 2 - Formação bruta de capital fixo como \% do PIB - emergentes selecionados (Ordenamento de acordo com a média do período - 2003 a 2013)

\begin{tabular}{ccccccccccccc}
\hline Estado & $\mathbf{2 0 0 3}$ & $\mathbf{2 0 0 4}$ & $\mathbf{2 0 0 5}$ & $\mathbf{2 0 0 6}$ & $\mathbf{2 0 0 7}$ & $\mathbf{2 0 0 8}$ & $\mathbf{2 0 0 9}$ & $\mathbf{2 0 1 0}$ & $\mathbf{2 0 1 1}$ & $\mathbf{2 0 1 2}$ & $\mathbf{2 0 1 3}$ & $\begin{array}{c}\text { Média } \\
\text { do } \\
\text { período }\end{array}$ \\
\hline China & 39,4 & 40,7 & 40,1 & 40,7 & 39,1 & 40,8 & 46,0 & 45,7 & 45,6 & 46,5 & 47,3 & 42,90 \\
\hline Coreia do Sul & 31,3 & 31,2 & 30,9 & 30,7 & 30,5 & 31,4 & 31,3 & 30,5 & 30,2 & 29,6 & 29,7 & 30,66 \\
\hline Índia & 24,6 & 28,7 & 30,3 & 31,3 & 32,9 & 32,4 & 31,7 & 30,9 & 31,8 & 30,4 & 28,3 & 30,29 \\
\hline Indonésia & 19,5 & 22,5 & 23,6 & 24,1 & 25,0 & 27,7 & 31,1 & 32,0 & 32,0 & 32,7 & 31,7 & 27,44 \\
\hline Arábia Saudita & 18,4 & 19,2 & 19,3 & 20,5 & 23,7 & 22,8 & 25,8 & 24,5 & 22,7 & 22,3 & 23,2 & 22,02 \\
\hline Colômbia & 18,1 & 18,8 & 19,7 & 21,6 & 22,5 & 23,1 & 22,7 & 21,9 & 23,6 & 23,7 & 24,5 & 21,83 \\
\hline México & 20,6 & 21,2 & 21,3 & 22,0 & 22,2 & 23,1 & 22,5 & 21,1 & 21,8 & 22,4 & 21,1 & 21,73 \\
\hline Rússia & 18,4 & 18,4 & 17,8 & 18,5 & 21,0 & 22,3 & 22,0 & 21,6 & 21,4 & 21,9 & 21,5 & 20,43 \\
\hline Turquia & 17,0 & 20,3 & 21,0 & 22,3 & 21,4 & 19,9 & 16,9 & 18,9 & 21,8 & 20,3 & 20,3 & 20,02 \\
\hline África do Sul & 15,5 & 16,0 & 16,8 & 18,3 & 20,2 & 23,1 & 21,5 & 19,2 & 18,8 & 18,9 & 19,3 & 18,87 \\
\hline Argentina & 12,5 & 16,9 & 18,3 & 19,7 & 20,1 & 19,8 & 17,5 & 17,9 & 18,5 & 16,9 & 17,0 & 17,73 \\
\hline Brasil & $\mathbf{1 5 , 3}$ & $\mathbf{1 6 , 1}$ & $\mathbf{1 5 , 9}$ & $\mathbf{1 6 , 4}$ & $\mathbf{1 7 , 4}$ & $\mathbf{1 9 , 1}$ & $\mathbf{1 8 , 1}$ & $\mathbf{1 9 , 5}$ & $\mathbf{1 9 , 3}$ & $\mathbf{1 8 , 2}$ & $\mathbf{1 8 , 2}$ & 17,59 \\
\hline Fons
\end{tabular}

Fonte: elaboração própria a partir dos dados disponíveis pelo Banco Mundial. 
A tabela acima mostra que países mais abertos ao comércio internacional (conforme as tabelas 5 a 8) - como os asiáticos China e Coreia do Sul, e os latinoamericanos, Colômbia, México - destinam uma porcentagem maior de seu PIB para os investimentos do que o Brasil. É importante destacar, adicionalmente, que os investimentos em capital fixo possuem externalidades positivas significativas, ou efeitos spillover na economia nacional no que tange ao comércio com os países vizinhos, pois de alguma forma poderão ser utilizados como diferenciais de competitividade regional (ANDERSON; NASH, 2006). Para Zanotto (2014),

O desenvolvimento nacional e o aumento da competitividade da indústria passam também pela elevação dos níveis de Formação Bruta de Capital Fixo da economia, ou seja, dos investimentos em tecnologia, inovação, infraestrutura e aumento da capacidade instalada do parque industrial. Para tanto, é fundamental criar o ambiente ideal para atração do capital externo, sobretudo por meio de investimento estrangeiro direto (IED) (ZANOTTO, 2014, p. 10).

De acordo com André Lara Resende (2013), os investimentos públicos são basilares para o crescimento brasileiro, conforme experiência desde a segunda metade do século XX. Para o economista, após a estabilização da inflação crônica na década de 1990, houve um aumento sistemático da carga tributária no Brasil, bem como o serviço público pouco contribuiu para o aumento da poupança doméstica. Ainda segundo o autor, "Infelizmente, numa atitude míope, ao invés de aumentar a taxa de poupança e de investimentos públicos, optou-se por aumentar os gastos correntes do governo, por dar estímulos ao consumo privado, toda vez que o crescimento de curto prazo dava sinais de perder o fôlego" (RESENDE, 2013, p. 105). Os investimentos em capital fixo fomentam o PIB potencial da economia, de forma a evitar que haja uma redução da produção quando o teto da capacidade instalada seja alcançado.

A formação bruta de capital fixo auxilia também a melhoria da infraestrutura do comércio, e aumento da competitividade internacional de uma indústria ao reduzir custos de transporte e comunicações. No contexto brasileiro, a elevação dos investimentos torna-se ainda mais importante, pois esse indicador poderia ajudar a reduzir outros fatores limitadores relacionados ao alto custo Brasil como a deficiente infraestrutura que dificulta o escoamento da produção interna. Como o País está geograficamente longe dos principais centros logísticos manufatureiros, bem como dos países hubs das cadeias globais de valor, os investimentos ajudariam a gerar uma maior 
dinamicidade à economia nacional e reduzir os custos de participação no comércio internacional.

\subsection{A Crise Internacional de 2008 e o Brasil}

Um dos efeitos da globalização financeira é o aumento da volatilidade e do sistema financeiro internacional aliado à crescente mobilidade de capital. Em virtude da acelerada queda das barreiras que emperravam o comércio e investimento internacionais, e graças ao notável progresso dos meios de comunicação, tornou-se muito mais fácil movimentar o capital entre países. A introdução dos avanços tecnológicos no cenário reduziria drasticamente o custo das transações financeiras, facilitando-as e tornando a distância entre os países quase que irrelevantes para as trocas econômicas, propiciando maior agilidade e maior segurança nas movimentações financeiras (MELLO; SPOLADOR, 2010, p.184).

Para Mello e Spolador (2010, p.184), o maior desafio moderno das economias é saber aproveitar as vantagens da disponibilidade da maior movimentação do capital sem criar instabilidade macroeconômica. No mundo atual, devido à enorme facilidade e velocidade de informação, as expectativas de natureza psicológica são potencializadas. Cria-se um verdadeiro sistema de vasos comunicantes na economia global, e uma crise pode provocar uma busca por liquidez que acaba contagiando outras economias (KINDLEBERGER. ALIBER, 2013). Em 2007, iniciou-se a crise econômico-financeira tendo como uma de suas origens a queda abrupta nos preços dos imóveis nos Estados Unidos, Reino Unido, Espanha, Irlanda e Islândia. Outros fatores que contribuíram para o prelúdio da crise foram: a crescente expansão da liquidez; a queda dos juros nos EUA; má regulação e/ou ausência dela; a longa expansão da atividade econômica que provoca uma euforia entre os investidores; a alta continuada dos preços dos ativos; e a especulação nociva e a imprudente assunção do risco (ROUBINI; MIHN, 2010).

É interessante notar que a crise recente apresenta uma inversão do sentido dos fluxos de capitais tradicionais. Nos séculos passados, o comum era que países em desenvolvimento importassem capitais dos países desenvolvidos, a exemplo da própria ascensão dos Estados Unidos como potência econômica no século XIX. Na crise de 2008/2009, o "fluxo de recursos dos países emergentes para os países ricos contribui 
para elevar a liquidez e reduzir as taxas de juros nos países desenvolvidos, em especial, nos Estados Unidos" (KINDLEBERGER; ALIBER, 2013).

O que explicaria essa inversão? Roubini e Mihn (2010) descrevem que as crises de 1980 e 1990 teriam convencido os emergentes a preparar-se melhor para eventuais recessões. Os países emergentes procuraram adotar políticas macroeconômicas mais responsáveis, e procuram impulsionar suas exportações, resultando em um excesso de poupança e volumes crescentes de reservas internacionais. De acordo com os autores (2010),

\begin{abstract}
As economias emergentes aprenderam duas lições nas crises da década de 1990: evitar déficits em conta corrente e acumular reservas em moeda estrangeira para se proteger de uma crise de liquidez internacional. Essas estratégias funcionaram durante a crise recente: países na Ásia e na América Latina com superávits e reservas substanciais em moeda estrangeira intervieram agressivamente para preservar as próprias moedas, assegurando aos investidores estrangeiros que eles poderiam enfrentar uma crise de liquidez sem precisar pedir ajuda ao FMI (ROUBINI; MIHN, 2010, p.284-285).
\end{abstract}

Contudo, as consequências da crise de 2008/2009 fizeram-se sentir nos países emergentes em decorrência de sues efeitos nos países avançados, por três mecanismos principais: as remessas, os fluxos de capitais e o comércio (GRIFFITH-JONES; OCAMPO, 2009). Como resultado, conforme Griffith-Jones e Ocampo (2009), a crise recente provocou a reversão em três choques positivos que os países em desenvolvimento experimentaram durante o período de crescimento econômico da década anterior: o financiamento excepcional, os altos preços das commodities e, para um significativo número de países, os altos fluxos de remessas. Segundo o estudo dos autores, os fluxos de capitais privados impactaram negativamente em maior proporção os países emergentes do que os países pobres, uma vez que aqueles estão mais integrados no sistema financeiro internacional, aumentando a volatilidade de suas taxas de câmbio. Ainda segundo os autores, os exportadores de manufaturas e serviços são afetados pelo declínio no volume de comércio, enquanto que os exportadores de matérias primas foram mais afetados por declínio dos preços das commodities (GRIFFITH-JONES; OCAMPO, 2009).

No tocante à mitigação dos efeitos da crise e retomada do crescimento, para o economista do Banco Interamericano de Desenvolvimento, Estevadeordal (2012), descreveu que "a recente crise econômica global acentuou a importância do comércio e da integração econômica como motores de crescimento e desenvolvimento nas 
Américas" (p. 22). Para o autor, as exportações servem como uma força anticíclica para as economias latino-americanas, ao ajudarem a promover crescimento e maior estabilidade econômica. Além disso, a conexão de países via comércio ajudaria a configurar a região em um plano mais próspero, bem como incentivar a cooperação em outras áreas (ESTEVADEORDAL, 2012, p.22).

Estevadeordal também destaca que a crise financeira global de 2008-2009 apresenta um turning point em matéria de política comercial na América Latina, o qual poderá levar a região a repensar seus modelos de desenvolvimento econômico e de engajamento global (2012, p.23). A crise serviu também de alerta à concentração de mercados por parte dos países em desenvolvimento. O Brasil, por exemplo, possui uma alta concentração de exportações de manufaturados para o mercado regional (como será visto no próximo capítulo). É racional e plausível pensar em uma diversificação dos mercados, e consequentemente, a mitigação dos riscos frente a choques externos.

O baixo nível de integração da economia brasileira à economia internacional apresenta um dilema quanto às suas implicações no contexto da crise. Por um lado, à exceção da produção nacional de minério e de aviões de porte médio ${ }^{36}$ (pois são setores fortemente dependentes das exportações), os efeitos da crise 2008/2009 foram sentidos de maneira menos ríspida, e menos preocupante em relação aos indicadores macroeconômicos do país, ao comparar-se com países mais abertos aos mercados globais como Chile, Coreia de Sul e México (SATO, 2009). Por outro lado, o baixo crescimento brasileiro comparado ao de outras nações emergentes pode ter uma de suas raízes justamente no fato de que há uma grande margem para a expansão do comércio exterior do país, seja na promoção de exportações de forma mais efetiva e qualitativa, seja na importação de insumo e de tecnologia para agregar competitividade à economia doméstica e exportações de alto valor agregado.

De acordo com Sato (2009), se o período de resposta à crise é keynesiano, o póscrise deveria ser schumpeteriano. A retomada do desenvolvimento de forma mais sustentável no médio e longo prazo demanda elementos estruturais impulsionadores da produtividade, como uma infraestrutura adequada, um moderno aparelhamento tecnológico para fomentar a produção industrial e a competitividade internacional. Diante disso, como argumenta o autor, o Brasil não saiu com vantagens estruturais após a crise de 2008, que teria como uma de suas raízes o baixo grau de integração da

\footnotetext{
${ }^{36}$ Juntamente com a Boeing dos Estados Unidos, a EADS da Europa e a Bombardier do Canadá, a Embraer é um empresa líder mundial no setor de aeronaves (STURGEON, et al., 2014, p. 46).
} 
economia brasileira na economia global (SATO, 2009). Além disso, no ano de 2010, conforme Giambiagi (2012), o Brasil ainda continuava com problemas similares aos de 1995: "uma taxa de investimento insuficiente, uma poupança doméstica baixa e uma competitividade deficiente de sua economia, fatores que estavam novamente por trás do ressurgimento do problema dos déficits elevados em conta-corrente" (GIAMBIAGI, 2012, p. 233).

Como afirmam Pastore, Gazzano e Pinotti (2013, p. 97), como reação à crise de 2008/2009, o governo brasileiro reduziu a taxa de juros e os superávits primários, e expandiu o crédito a fim de estimular a demanda agregada e a atividade econômica. Essa política teria como objetivo estimular a economia do país, com aumento da geração de emprego, da inclusão social, e de melhorias no padrão de consumo em massa. Nessa política tiveram participação fundamental o Banco Nacional de Desenvolvimento Econômico e Social (BNDES) e bancos públicos e de economia mista (CRUZ et al., 2012). No entanto, a elevação dos salários reais na indústria de transformação acima da produtividade média do trabalho empregado no setor viria por aumentar o custo unitário do trabalho (PASTORE; GAZZANO; PINOTTI, 2013). Combinada com o contágio externo, pois os preços do setor industrial tendem a ser em grande parte determinados no cenário internacional, essa política seria inadequada para o período posterior a 2010, o que de acordo com Pastore, Gazzano e Pinotti (2013), viria por provocar uma estagnação da produtividade do setor manufatureiro. Além disso, o Brasil apresentou baixo crescimento desde 2011, quando obteve uma variação real do PIB ao ano antecedente de 3,9\%, seguido de 1,8\% em 2012, 2,7\% em 2013, e crescimento nulo de 0,1\% em 2014 (IBGE data, 2015).

Cabe destacar que essa opções de política macroeconômica adotadas, somam-se a fatores de ordem estrutural - e até certo ponto, históricos - como a deficiente condição infraestrutural, distorções na estrutura tributária e relativa baixa qualidade da mão de obra, dificultando a inserção da economia brasileira de forma mais efetiva e qualitativa na economia global (AMARAL, 2013, p. 25; BACHA; BAUMGARTEN, 2013; BAUMANN, 2014a; CNI, 2015; GIAMBIAGI; SCHWARTSMAN, 2014). A baixa inserção produtiva do Brasil nos novos padrões de comércio internacional podem aumentar os custos de oportunidade do relativo isolamento ao longo do tempo, o que, por conseguinte, revelam-se como limites à emergência do País neste princípio de século. 
Após analisar as políticas domésticas não convergentes com, cabe uma apreciação de como a integração regional influiu em ganhos ou perdas para a inserção competitiva do País nos novos padrões de comércio internacional. O Brasil possui grandes dilemas quanto à integração sul-americana, definida como maior prioridade da política externa brasileira desde 2003. O cenário regional exibe grandes dilemas políticos e econômicos no que se refere aos ganhos e perdas de competitividade das exportações brasileiras, bem como à constituição futura de uma cadeia de valor em âmbito regional. 


\section{CAPÍTULO 3 - REGIONALISMOS NA ERA DAS CADEIAS DE VALOR E OS DILEMAS CONTEMPORÂNEOS DA INTEGRAÇÃO SUL-AMERICANA}

A integração regional está nos discursos dos governantes latino-americanos há décadas, mas sua promoção efetiva ainda permanece limitada quando comparada aos três grandes centros produtivos regionais (Leste Asiático, Europa, e América do Norte). Dados da OCDE e OMC mostram que a América Latina (a exceção do México) ainda carece de mecanismos de integração produtiva regional, além de demonstrar pouca participação nas Cadeias Globais de Valor. Houve um afastamento do aspecto econômico da integração na América do Sul, o que pode ter ensejado o distanciamento do Brasil dos novos padrões de comércio internacional, já que mais de um terço das exportações de manufaturados do País tem como destino o mercado regional (Secex data, 2015).

Esse capítulo tem como propósito discutir e analisar as dinâmicas atreladas ao novos padrões de comércio bem como oportunidades aparentes em exercício de integração regional, com destaque aos caminhos percorridos pelo Mercosul na primeira década e meia do século XXI. Torna-se importante analisar os caminhos seguidos pela integração econômica sul-americana e dilemas contemporâneos do Mercosul, a fim de identificar os desafios a serem superados para que a região possa criar as suas próprias cadeias de valor. Entretanto, como será exposto, o Mercosul adotou trajetória contrária à integração econômica de fato, aumentando os obstáculos para a inserção competitiva da economia brasileira nas CGV.

\subsection{O Regionalismo "Pós-Hegemônico" após o Colapso da ALCA}

Inicialmente denominada pelo governo norte-americano de George H. W. Bush (1989-1993) de "Iniciativa para as Américas", a proposta de criação do Acordo de Livre Comércio das Américas - ALCA (conforme mudança na denominação do projeto realizada no governo norte-americano de Bill Clinton) visava a eliminação paulatina das barreiras alfandegárias no continente americano, o que poderia dar origem à maior zona de livre comércio do mundo com 34 países (SOUZA, N. A. 2009, p. 125). Ao longo da década de 1990, foram realizadas diversas reuniões entre os chefes de Estado do continente americano, sendo a primeira a Cúpula das Américas realizada em 1994 em 
Miami, primeira grande reunião internacional de governantes no pós-guerra fria que teve como tema central a promoção das negociações em torno da integração hemisférica. O momento era propício para o avanço das negociações na região, na medida em que o subcontinente latino-americano continha diversas lideranças de orientação econômica mais ortodoxa que os períodos anteriores.

A agenda de cobertura comercial seria ampliada, de um foco na liberalização de bens para, além desta, uma 'segunda geração' de temas (ESTEVADEORDAL; SUOMINEM, 2009) - serviços, direitos de propriedade intelectual, compras governamentais, etc., bem como de um simples universo de regras de origem, para um sistema de regras de origem mais complexo e rigoroso. Ainda de acordo com Devlin e Giordano (2004), em termos teóricos, no curto e médio prazo, os resultados dos fluxos de comércio e investimentos de uma integração "Norte-Sul" podem ser revelar-se desiguais entre e nos países, mas no longo prazo, podem favorecer a convergência econômica e melhorar da distribuição de renda na América Latina (DEVLIN; GIORDANO, 2004, p. 171), ou mesmo melhor difusão tecnológica (ALMEIDA, 2013a).

A proposta de criação da ALCA insere-se nos "novos regionalismos", o que na noção de Devlin e Giordano (2004), diferem-se dos "velhos regionalismos" na medida em que esses apoiavam o protecionismo via substituição de importações (ISI) ${ }^{3738}$, aqueles estariam voltados ao modelo market-oriented. Os velhos regionalismos do século XX na América Latina eram mais sensíveis e descrentes às relações comerciais entre economias pequenas e grandes, além de menos rigorosos quanto ao regime político dos Estados participantes. Para os autores, "the New Regionalism is an integral

\footnotetext{
${ }^{37}$ De acordo com o Novíssimo Dicionário de Economia (SANDRONI, 1999, p. 581), a substituição de importações é um conceito elaborado por economistas da Comissão Econômica Especial para América Latina e Caribe (CEPAL) para designar um processo de desenvolvimento interno, estimulado por desequilíbrio externo e que objetiva a dinamização, o crescimento e a diversificação do setor industrial. Nesse sentido, o conceito iria além da produção local de bens tradicionalmente importados.

${ }^{38}$ Do ponto de vista do setor industrial, uma das razões para o colapso de empresas latino-americanas com a abertura comercial da década de 1990 deve-se à estrutura industrial demasiadamente diversificada produzida pelo período de adoção da ISI, a tal ponto que prejudicava a sua eficiência (LLOSA, 2005). Houve, assim, um acúmulo de empresas de baixa qualidade, que não acompanhavam o ritmo das empresas de alto desempenho. Na análise de Dani Rodrik (2002), a dosagem de "proteção" e "disciplina" em termos industriais na América Latina foi ineficiente. Para o autor, no período de adoção da ISI, os governos sul-americanos ofereciam massivos "incentivos" sob forma de proteção contra importações, porém insuficiente disciplina (castigo). Na década de 1990, o processo supostamente, na visão do autor, teria sido invertido: foram oferecidos muito poucos incentivos, porém uma disciplina considerável trazida pela abertura comercial e mercado competitivo (RODRIK, 2002, p. 286). È possível deduzir a partir dessas análises que as privatizações de empresas estatais ineficientes seriam reformas fundamentais para ajudar a solucionar o problema.
} 
part of the structural adjustment process that is designed to make the economies more market oriented, open, outward looking, and internationally competitive in a modern democratic institutional setting" (DEVLIN; GIORDANO, 2004, p.145).

Em 2005 ${ }^{39}$, entretanto, na IV Cúpula das Américas em Mar del Plata, Argentina, as negociações para o projeto de integração da ALCA fracassaram, quando Brasil e EUA exerciam conjuntamente a presidência das negociações. Várias foram as motivações para o virtual fim das negociações em torno do projeto. Do ponto de vista dos Estados Unidos, a prioridade na política externa do governo Bush em torno da "Guerra ao Terror" decorrente dos atentados de setembro de 2001, reduziu tanto o interesse em torno das negociações com os países latino-americanos quanto a própria vontade política do país em lidar com os interesses protegidos do forte setor de bens agrícolas americano, reticentes quanto a uma maior liberalização.

Do lado da conjuntura sul-americana, surgiram novas lideranças políticas de cunho mais heterodoxo e nacionalista do que aquelas da década de 1990, e que buscaram a revalorização do protagonismo do Estado em relação ao mercado, e um aumento da intervenção governamental tanto em âmbito interno - no intuito de promoção de um desenvolvimento via distribuição de renda e agenda de programas sociais, quanto em âmbito externo, "em busca de afirmação regional no âmbito sulamericano e maior autonomia nas relações com os Estados Unidos" (AYERBE, 2008, p. 9). Dentre esses governos, destacam a ascensão de Hugo Chávez na Venezuela, em 1999; Lula no Brasil, em 2003 ${ }^{40}$; Nestor Kirchner na Argentina, também em 2003; e, Evo Morales na Bolívia em 2005.

Esses governos sul-americanos promoveram a defesa plena do princípio da soberania nacional, o que se tornou mais evidente com o uso do termo "regionalismo pós-hegemônico" no século XXI (RIGGIROZZI; TUSSIE, 2012). Na acepção de Riggirozzi e Tussie (2012, p.11-12), esse tipo de regionalismo enseja um movimento regional de integração de deslocamento parcial das iniciativas ditas 'neoliberais' lideradas pelos Estados Unidos de integração hemisférica, e como contestação ao "regionalismo aberto" dos anos 1990. Esse modelo de regionalismo, bem como a ascensão de governos de orientação mais heterodoxa - em menor medida, na Colômbia, Chile e Brasil, o qual continuou boa parte das políticas econômicas do governo anterior,

\footnotetext{
${ }^{39} \mathrm{O}$ ano de 2005 havia sido delimitado em 1995 como expectativa-fim para conclusão das negociações.

${ }^{40}$ Cabe ressaltar que no primeiro mandato presidencial do governo Lula (2003-2007) a administração da política econômica tenha a princípio adotado mais continuidade do que mudanças em relação ao segundo mandato do governo FHC (SOARES DE LIMA; COUTINHO, M., 2007).
} 
pelo menos a princípio -, e resistência à hegemonia norte-americana são em grande medida derivados do movimento antiglobalização do final dos anos 1990, após a ocorrência das crises financeiras nos países em desenvolvimento ou emergentes, a exemplo de Rússia, Argentina, Brasil e Tigres Asiáticos. Surgiram várias reações internacionais contra aspectos da globalização capitalista, o suposto "neoliberalismo", e a influência dos EUA e do FMI no cenário internacional. Um exemplo desse movimento ocorreu no dia 30 de novembro de 1999, na "batalha de Seattle", quando 40 mil manifestantes confrontaram os líderes do mundo desenvolvido e industrializado na reunião ministerial da Organização Mundial do Comércio nos EUA, para protestar contra a globalização econômica (KARNAL et. al., 2007). Com isso, como afirmou Estevadeordal, "(...) some governments in Latin America, pressured by a public backlash against globalization, (were and) are turning their backs on open trade policies" (ESTEVADEORDAL, 2012, p. 23) ${ }^{41}$.

Em meio às negociações da ALCA, os cientistas políticos Eduardo Viola e Carlos Pio (2003) advertiam que as opções do governo brasileiro estavam mais voltadas aos aspectos dogmáticos e doutrinários do que à análise das dinâmicas econômicas internacionais da realidade. Essas percepções e doutrinas estariam muito mais voltadas a uma versão popularizada do estruturalismo econômico (AMARAL, 2013), o qual muitas vezes se confunde com o próprio nacionalismo enraizado no País desde a década de 1960. Nesse sentido, as experiências de países que se inseriram em processos de interdependência econômica e integração regional e global não parecem ganhar grande espaço na discussão entre os policy-makers brasileiros e no Mercosul. Dentre essas experiências estariam a pujança na indústria mexicana pós-NAFTA na fase ascendente da economia dos EUA na década de 1990, e a superação da armadilha da classe média por Espanha, Portugal, Irlanda e Grécia após o ingresso no projeto europeu de integração (VIOLA; PIO, 2003, p. 181;183).

Dentre as razões para o bloqueio brasileiro da ALCA, a despeito da hipótese do antiamericanismo por parte do Brasil e demais governos sul-americanos - defendida também, além dos autores acima, por Pedro da Motta Veiga (2006), Paulo Roberto de

\footnotetext{
${ }^{41}$ Nolte e Wehner relatam uma guinada do foco da integração do tema econômico para orientações políticas: "(...) since the turn of the century, Latin American regionalism has become less focused on economic liberalization and more political in its orientation. This change was the result of votter disappointment with economic globalization at the national level and a shift to left-oriented governments. The new regionalism projects sought political consensus building, the promotion of regional independencies and an increase in cooperation in nontrade issues (e.g., energy, infrastructure, finance and regional security)." (NOLTE; WEHNER, 2013, p. 3, grifo nosso).
} 
Almeida (2013d), e Roberto Abdenur (2014) -, o ex-Ministro da Relações Exteriores, Celso Amorim, declarou que os termos de negociação da ALCA não correspondiam aos interesses brasileiros (AMORIM, 2010). Para Amorim, as negociações sobre os temas sensíveis ao Brasil, como serviços, compras governamentais e investimentos estavam progredindo, enquanto eram bloqueados temas de maior interesse brasileiro, como subsídios agrícolas e antidumping (AMORIM, 2010, p, 217). O fracasso das negociações em torno da ALCA foi visto também como, até certo ponto, favorável à promoção da integração sul-americana para a construção da liderança brasileira, de modo que o Brasil possuísse maior margem de propulsão do intuito brasileiro de constituir-se como líder e potência regional, o que de fato, tem sido passível de diversos questionamentos quanto à sua efetivação (Conf. MALAMUD, 2011).

De fato, o colapso do projeto da ALCA em 2005 e a não ensejada retomada das negociações fracassadas tornaram mais distante um sistema de regulação efetivo comum de regras de origem em tal âmbito continental. Tornou-se menos possível também a aspiração de constituição de uma cadeia de valor regional. Do ponto de vista dos Estados Unidos, o país conseguiu costurar acordos comerciais com os países latinoamericanos de orientação de política externa mais globalista e economias de mercados mais consolidadas (ALMEIDA, 2013; VIOLA; LEIS, 2007), como os assinados com Costa Rica, Panamá, Colômbia, Peru e Chile.

Há uma dupla interpretação para a proliferação de acordos no continente americano. Há o argumento em prol do aspecto positivo em termos de uma "geometria variável", segundo a qual haveria um 'possível' benefício de transitar-se entre distintos acordos para alcançar determinado objetivo; e o aspecto negativo (e mais comum) quanto ao "spaghetti bowl", conceito que denota uma sobreposição de diversos acordos comerciais, de modo que possa levar à ligeira ineficiência dos ganhos comerciais em sentido agregado caso não haja a unificação dos mesmos acordos e das regras de origem (BHAGWATI, 2003; ESTEVADEORDAL, 2012).

Com a proliferação de acordos na região com as redefinições de orientações de política externa na região, é possível identificar, de forma simplória, três tipos de projetos regionais de integração na América: (1) os acordos com forte ênfase comercial (trade-driven), com possível "trânsito a um multilateralismo mais amplo" (como o NAFTA, a emergente Aliança do Pacífico, e a proposta da derrocada ALCA); (2) os acordos "híbridos" que combinam a tentativa de avanços em matéria comercial e possivelmente novos elementos, "com doses de intervenção estatal e objetivos políticos 
pós-comercias", o que pode ser interpretado como "state-driven" ou "state-led" (ex: Unasul, SICA - Caricom, Mercosul, Comunidade Andina); e, (3) um modelo que enfatiza radicalmente os aspectos sociais e políticos da integração, com forte intervenção estatal na economia, e dirigido por ideias de inspirações socialistas (A ALBA, liderada pela Venezuela) (NOLTE; WEHNER, 2013, p. 3; RIGGIROZZI; TUSSIE, 2012, p. 11). O que se pode inferir de uma heterogeneidade de modelos de integração na América é a complexidade e maior dificuldade em torno de um projeto de integração hemisférica, em especial, tal qual como foi idealizado em boa parte da década de 1990 em torno de um Acordo de Livre Comércio das Américas, que se aproximaria muito mais do primeiro modelo descrito, "trade-driven project".

Apesar de aparentemente possuir uma maior margem de atuação regional em prol de seu projeto de integração regional, de acordo com Hurrell (2010, p. 5-6), o Brasil possui diversos desafios para a construção de uma liderança regional. Segundo o autor, o país "carece dos recursos econômicos para engajar-se na provisão de larga escala de bens públicos regionais"; possui dificuldades para cultivar "followership" com os vizinhos quanto a aceitação de seu papel regional; além de uma ambivalência: se por um lado, o Brasil possui grande margem para implementar suas ideias nas instituições regionais que possam fortalecer uma liderança, por outro, "as instituições regionais são fracas", pois, para Hurrell, "Mercosur is arguably less coherent and effective than it was in the 1990s and many of the new institutions are underdeveloped, in no small part due to Brazil's continued reluctance to bind itself to international institutions that would restrict its autonomy" (HURRELL, 2010, p. 5 - 6).

\subsection{Os Dilemas Contemporâneos do Brasil no Mercosul}

\section{a) Os Desafios para a Construção de uma Cadeia de Valor Regional}

Os ensejos criacionistas do Mercosul tiveram ambição do avançado conceito europeísta de integração regional, principal projeto integracionista em execução. As regulações comerciais inseridas nos marcos jurídicos do bloco sul-americanos também estavam voltadas a um momento histórico específico. A maioria dos países latinoamericanos nos início dos anos 1990 parecia comprometida com a liberalização comercial. 
Entretanto, no século XXI, há alegações de que o Mercosul permanece insuficientemente aberto (ALMEIDA, 2013a; 2013d; BARBOSA, 2013), o que o impede de avançar a etapas mais profundas de integração. A questão institucionalteórica sobre o modelo de governança intergovernamental e não supranacional no bloco também tem apresentado limites quanto à vigilância do cumprimento das regras do jogo por parte dos governantes.

Para Vera Thorstensen e Ferraz (2013) \& Pereira (2013), há uma necessidade de atualização do marco regulatório do Mercosul, de forma que abarque a superação dos principais entraves para os fluxos comerciais e produtivos. As negociações no Mercosul também pouco incorporam os "novos termas" como investimentos, propriedade intelectual, serviços e compras governamentais, para citar alguns, e quando os incorpora, possuem baixo grau de compromisso (PEREIRA, L., 2013). Para Lia Valls Pereira (2003), o fracasso das negociações em torno da ALCA e a crise argentina de 2001 são alguns dos motivos pelos quais pouco tenha se tratado desses temas na agenda do Mercosul, questões estas, que "estão presentes nos acordos de livre comércio da nova geração" (PEREIRA, L., 2013, p. 5). A economista também destaca que os acordos do bloco sul-americano com os demais países da região - Chile, Bolívia, Colômbia, Equador, Peru, Venezuela - "se restringiram ao comércio de mercadorias" (p. $5)$.

De fato, o Tratado de Assunção, que deu origem ao Mercosul em 1991, não traz nenhuma menção explícita ao tema da complementaridade produtiva entre seus Estadosmembros. O art. 11 do anexo I que trata do "Programa de Liberalização Comercial" no Tratado, diz que "os Estados Partes coordenarão as políticas macroeconômicas e as setoriais que se acordem, (...) começando por aquelas relacionadas aos fluxos de comércio e à configuração dos setores produtivos dos Estados Partes" (grifo nosso). Essa citação pode ser interpretada como uma declaração de viés um pouco segregacionista e nacionalista dos países, pois os setores produtivos supostamente referidos seriam de cada Estado-membro, não necessariamente do Mercosul.

A transição de ênfase da política externa brasileira da América Latina - como exposto na Constituição Federal do Brasil de 1988 - para a América do Sul foi realizada durante o governo Fernando Henrique Cardoso na década de 1990. Uma das grandes motivações foi o desenvolvimento do NAFTA, o qual concedeu um maior engajamento do México (a outra potência latino-americana) ao mercado norte-americano, e proporcionou maior margem de atuação do Brasil para com o seu entorno. No governo 
Lula, com o então Ministro Celso Amorim, o projeto de liderança brasileira na América do Sul passou por maior institucionalização por meio da recriação da antiga Comunidade Sul-americana de Nações - CASA, que viria a ser a União de Nações Sulamericanas - UNASUL. Por mais que tenha havido uma proliferação de instituições e órgãos com o objetivo de promoção da integração regional sul-americana, e a ampliação da agenda do Mercosul e da UNASUL, os resultados efetivos desse alargamento do tratamento da integração são discutíveis.

Apesar de constituir-se como um projeto de integração que vai além da área comercial, o Mercosul pouco avançou em seu objetivo de consolidação de uma União Aduaneira, e tampouco progresso para a formação de um Mercado Comum, o que dá nome ao grupo (ALMEIDA, 2013a; BARBOSA, 2014; BAUMANN, 2013a; MARKWALD, 2014). O bloco ampliou demasiadamente a sua agenda para as áreas política e social, a tal ponto de ser considerado pelo embaixador brasileiro em Caracas (Venezuela) Ruy Pereira como "multifuncional" (PEREIRA, R., 2013). Esse alargamento de temas, contudo, além de duplicar competências com outras instituições criadas (Unasul e CELAC, por exemplo), pode desviar a atenção de negociadores da matéria comercial (BARBOSA, 2014) e de esforços para a realidade econômica do bloco $^{42}$.

O sucesso da integração dos países do Leste Asiático - região até então similar em aspectos de subdesenvolvimento com a América Latina - demonstrou em parte que para que ocorresse uma integração de fato seja necessária a eliminação de barreiras comerciais, a facilitação de investimento e de negócios, bem como a redução da burocracia estatal que possa impedir o dinamismo necessário para o bom funcionamento das relações de mercado entre os agentes econômicos. Do ponto de vista de política externa em seu aspecto econômico, além de estreitar os laços com os vizinhos, os países do Leste Asiático voltaram-se a mercados também consolidados, em especial, aos Estados Unidos.

É notável que a geografia seja contraditória com o Brasil em uma inserção progressiva nas CGV. O País se encontra à margem desse processo, nas instâncias mais

\footnotetext{
${ }^{42}$ É importante notar que a União Europeia, maior e mais avançado projeto de integração regional do mundo, continua a passar por dificuldades ao implementar etapas de integração sem concluir estágios anteriores. Além de muitos Estados-membros não terem cumprido com os dispositivos legais de ingresso contidos no Tratado de Maastricht de 1992, a UE têm dificuldades para fazer cumprir compromissos nacionais de Estados integrantes da Zona do Euro de modo que não ocasione a perda de confiança no valor da moeda. Uma das origens desse problema reside justamente ao firmar uma união monetária sem uma unidade fiscal.
} 
baixas, em grande parte pelo fornecimento de commodities que se inserem no processo de produção de outras regiões e países. A proximidade geográfica e cultural dos EUA e da Europa é um fator muito favorável que pode não ter sido devidamente aproveitado por razões doutrinárias da visão da política externa brasileira desde 2003. A distância do Brasil em relação ao continente asiático e ao Oceano Pacífico também são fatores limitadores dessa inserção, mesmo que a revolução tecnológica e das telecomunicações tenham ajudado a reduzir consideravelmente os custos de transações.

Com esta realidade geográfica, torna-se plausível perguntar: por que não há no Mercosul um processo de integração comercial com desintegração da produção da envergadura dos esquemas de integração profunda? Ao ser arguido que o Brasil pouco participa das cadeias globais de valor, é plausível raciocinar que o país esteja à margem desse processo, pois sua região, a América do Sul, e seu principal acordo comercial, o Mercosul, estão também à margem desse processo ${ }^{43}$. O Mercosul, considerado por muitos o maior projeto até então entre países não desenvolvidos, afastou-se de seus objetivos traçados no Tratado de Assunção, como o da liberalização comercial ampla para a formação de uma mercado comum (ALMEIDA, 2013a; 2013d; BARBORSA, 2013; ZANOTTO, 2013), o que pode ter contribuído para a ausência de mecanismos institucionais eficazes para a adoção de uma integração pragmática, econômica de fato, via complementaridades produtivas. A superação de barreiras comerciais, políticas, ideológicas e de orientação dos rumos da integração regional devem ser superadas a fim de propiciar a consolidação de cadeias produtivas na América do Sul (BAUMANN, 2014a, p. 51).

Trata-se esse de um obstáculo severamente crítico para a construção de uma cadeia de valor na América do Sul, haja vista o viés regional das cadeias globais de produção. Estevadeordal, Blyde e Suominem (2013), destacam esse viés. O processo contemporâneo de consolidação da fragmentação e dispersão da produção internacional não é distribuído uniformemente no globo, e concentra-se nas três regiões que souberam implantar a separação de tarefas, de harmonização de ciclo de negócios, e assinatura de acordos comerciais preferenciais (Leste Asiático, Europa e América do Norte, supracitadas). Aspectos geográficos, o nível de integração prévia, a redução dos custos de transporte, e a superação de rivalidades entre nações são alguns dos fatores que também são determinantes para a continuidade e aprofundamento de um processo de

\footnotetext{
43 Até o primeiro trimestre de 2015, a OCDE ainda não disponibilizava os dados de participação nas Cadeias Globais de Valor de todos os membros do MERCOSUL, apenas de Brasil e Argentina.
} 
integração para a formação futura de uma cadeia regional de valor. Os custos de coordenação mais baixos entre países próximos geograficamente reforça a orientação regional de uma cadeia de valor.

A distância física entre fornecedores e compradores de uma cadeia de produção pode gerar a necessidade de atividades de armazenamento e estoque, atividades essas que, não são tendências nas práticas modernas de gerenciamento de produção (ESTEVADEORDAL; BLYDE; SUOMINEM, 2013, p.10). O modelo "Just in time" promovido inicialmente pela empresa automobilística Toyota nos anos 1980 é uma evidência da eficiência dessa prática.

Para Estevadeordal, Blyde e Suominem (2013, p. 16), "quanto maior a distância entre os países participantes, menores as chances de que emerja uma cadeia produtiva global" e "a distância física diminui substancialmente o valor agregado estrangeiro" (p.15). Segundo estudo empírico dos autores, "um aumento de $10 \%$ na distância reduz o valor agregado estrangeiro em média, em cerca de 67\%", assim como "a participação no mesmo APC aumenta o valor agregado estrangeiro, em média, de 15\%" (ESTEVADEORDAL; BLYDE; SUOMINEM, 2013). Ainda segundo os autores, "os países distantes das principais regiões $\mathrm{CGV}$ podem procurar desenvolver as suas próprias cadeias de valor regionais" (p. 17). No caso da América do Sul, as deficiências em termos de infraestrutura, bem como uma maior demanda por portos e aeroportos, além da geografia são entraves importantes para a construção de uma cadeia de valor regional. Ao utilizar-se das distâncias entre as capitais dos países (grande áreas circulares), de acordo com os autores, enquanto a distância bilateral média entre todos os países do Leste Asiático e ASEAN é de cerca de 2,4 mil quilômetros, e de todos os 27 países da UE é de 1,5 mil quilômetros, esse valor na América Latina e Caribe é de 3 mil quilômetros, elevando-se a 3,2 mil quilômetros quando se considera a inclusão de EUA e Canadá no cálculo (ESTEVADEORDAL; BLYDE; SUOMINEM, 2013, p. 17).

O aprofundamento de um processo de integração regional demanda uma ação concertada de nações, com amplos compromissos, bem como convergência macroeconômica e similaridades na estrutura econômica no longo prazo. Para isso, demanda-se a redução de assimetrias que impeçam a sustentabilidade da integração econômica.

Nesse intuito, no âmbito do Mercosul, há de se destacar a procura pela redução das assimetrias por meio do implementado Fundo para a Convergência Estrutural do Mercosul - FOCEM. Criado em 2007, o FOCEM destina recursos a projetos para a 
melhoria da infraestrutura e na distribuição de renda aos menores parceiros do bloco, Paraguai e Uruguai, bem como às áreas mais precárias de Brasil e Argentina. Contudo, o FOCEM, com R\$ 100 milhões de recursos anuais compartilhados por seus membros, tem um orçamento limitado frente à dura superação dos desafios das assimetrias do bloco, resultantes - cabe salientar - de aspectos políticos, sociais, econômicos, estruturais, e históricos. Essa limitação de recursos é reconhecida, inclusive, pelo próprio Embaixador Samuel Pinheiro Guimarães, ex-Alto Representante Geral do Mercosul (2011-2012): "Com cem milhões de dólares constrói-se apenas uma estrada de cem quilômetros, mais nada. É claramente insuficiente. É preciso aumentar essa cifra" (GUIMARÃES, 2012, p. 95).

Devido à distância entre as capitais na América do Sul, torna-se ainda mais importante a busca pela integração física na região a fim de pavimentar um caminho mais promissor para a integração comercial-produtiva e das sociedades nacionais. A Iniciativa para a Integração da Infraestrutura Regional Sul-Americana - IIRSA proposta em agosto de 2000 visa à integração dos países sul-americanos em termos de transporte, energia, telecomunicações e infraestrutura, e está aos cuidados do Conselho SulAmericano de Infraestrutura e Planejamento - COSIPLAN, órgão da UNASUL, criado em agosto de $2009^{44}$. Contudo, como afirma Rubens Barbosa (2013), o COSIPLAN não promoveu grandes avanços no projeto. A IIRSA poderia vir a ser uma instituição propulsora da redução das assimetrias e base para a logística e infraestrutura a fim de uma integração profunda (CERVO, 2014). Maiores investimentos para uma perspectiva de longo prazo da integração física e de infraestrutura na América do Sul são essenciais para a constituição de cadeias de valor regionais.

O Brasil também terá amplos desafios competitivos na inserção nas cadeias globais de valor já estabelecidas, em especial, na obtenção de posição central ou núcleo da cadeia. Relações de confiança e longos contratos construídos entre fornecedores, fabricantes e modeladores de produtos podem impor dificuldades para a inserção de novos países. Diante desse desafio, criar novas cadeias de valor, sobretudo em âmbito regional, é uma ação alternativa e congruente com a inserção nos novos padrões de comércio. A América do Sul não possui um processo produtivo da envergadura dos centros mais dinâmicos das cadeias de valor, mesmo com diversas tentativas e discursos

\footnotetext{
${ }^{44}$ Disponível em: <http://www.planejamento.gov.br/ministerio.asp?index=10\&ler=t9226.>. Acesso em: 15 fev. 2015.
} 
pró-integração na sua história, e ao que tudo indica, o Brasil, principal economia da região, terá grande responsabilidade para a condução desse processo ${ }^{45}$.

\section{b) O Trade-off do Estágio de Integração: entre a União Aduaneira Imperfeita e a Área de Livre Comércio}

Uma discussão que ganhou grande destaque nos últimos anos gira em torno de um retorno do Mercosul ao molde de uma Área de Livre Comércio devido à perda de consenso nas lideranças políticas brasileiras sobre os rumos da integração regional. A integração dos países membros configura uma União Aduaneira imperfeita, com diversas exceções à Tarifa Externa Comum, e em grande parte por um suposto descumprimento das regras do jogo. O problema adicional é o fato de que o Mercosul não assinou tratados comerciais de grande relevância econômica desde 2003, apenas com três países e de alcance limitado (Egito, Israel - com o qual a Venezuela sequer possui relações diplomáticas, e Autoridade Palestina), ainda não notificados na $\mathrm{OMC}$, a tábua-lei dos acordos. As dificuldades de elaboração de uma proposta conjunta para negociações comerciais tem sido um grande entrave para a conclusão de acordos como o do Mercosul - União Europeia (que teve suas negociações iniciadas em 1999), ou com países de maior dinamismo econômico e de mercados mais robustos.

Há críticas recorrentes de empresários brasileiros quanto à falta de soluções de controvérsias efetivas no Mercosul, o que cria um ambiente de insegurança jurídicocontratual. Ao declarar-se o estágio de integração como "União Aduaneira imperfeita", está implícito que há quebra nas regras da definição de uma UA de fato. Esse fator reside, dentre outros motivos, na dupla cobrança de impostos sobre importação realizada no mercado regional, à exclusão de setores, e à extensa lista de exceções a TEC (GUIMARÃES, 2014). As perfurações à TEC reforçam também a dificuldade de fazer valer as regras que criem uma previsibilidade maior para uma relação sustentável do comércio entre os países e que institua um sistema de confiança entre os empresários.

\footnotetext{
45 Desde 2013, o Instituto de Pesquisa Econômica Aplicada (IPEA) tem como grande projeto a identificação de complementaridades produtivas entre os países da América do Sul a fim de subsidiar a formular as decisões políticas para a constituição de cadeias regionais de valor. Disponível em: $<$ http://www.ipea.gov.br/portal/index. php?option=com_ content\&view=article\&id=16921>. Acesso em: 10 fev. 2015.
} 
Contudo, a opção de retorno ao nível de área de livre comércio parece ser praticamente inviável, por três motivos: de natureza jurídica, política, e econômica. Primeiro, haveria uma necessidade de reformulação do Tratado de Assunção, que pressupõe a adoção de uma política comercial comum pelos seus Estados membros, e das regulamentações adjacentes, o que poderia resultar em perda maior ainda da credibilidade dos acordos firmados. Segundo, porque parece não ser do interesse das lideranças políticas dos governos dos países-membros, o que seria considerada uma opção muito radical, e poderia também resultar em grandes custos e entraves diplomáticos caso a ação fosse ao menos "aspirada". Terceiro, por razões de resguardo de interesses setoriais e preservação de certa "garantia" de exportações industriais brasileiras, pois em torno de $90 \%$ das exportações do Brasil para o Mercosul é composta por bens manufaturados (BARBOSA, 2014).

Uma eventual liberação dos países do Mercosul visando flexibilizar as negociações em bloco de modo que os Estados-membros possam firmar acordos isoladamente poderá reduzir o acesso preferencial aos produtos brasileiros e trará preocupações defensivas para o Brasil (ALVIM; RIZZO, 2014, p. 29). Este fator é agravado diante da relativa baixa competitividade da indústria brasileira (como já foi demonstrado aqui, referente ao estudo da CNI: "Competitividade Brasil - 2014"46) e pelas preferências comerciais aos produtos nacionais. Esse fato está ocorrendo em parte, pois além das importações chinesas pela Argentina, há uma perda de mercado brasileira nos países da Aliança do Pacífico, devido às assinaturas de TLCs com os EUA e países asiáticos (MARKWALD, 2014). Além desses fatores, o alto "Custo Brasil" torna mais improvável que os produtos industriais brasileiros alcancem mercados globais mais competitivos no curto prazo sem grandes reformas estruturais e sem adotar um cronograma de liberalização comercial efetivo (BAUMANN, 2013b).

Importante destacar os problemas que poderiam ser resultantes de uma eventual substituição da união aduaneira de acordo com estudo de Kume e Piani (2005): a) "a transferência do debate sobre a questão da tarifa externa comum para o de índice de conteúdo regional, o que pode até levar a um aumento do desvio de comércio, em detrimento do país 'pequeno'“; b) "a criação de restrições ao comércio intrabloco, decorrentes dos custos de funcionamento do regime de origem"; e, c) "a perda do poder

\footnotetext{
${ }^{46}$ De acordo com estudo da CNI (2015), o custo do trabalho no Brasil se elevou em maior medida do que o de outros 13 países considerados comparáveis ao País.
} 
de barganha nas negociações bilaterais por parte de países menores e mais especializados na produção agrícola" (KUME; PIANI, 2005, p.387).

Diante desse quadro, o Brasil enfrenta duas opções no que tange aos estágios de integração do Mercosul de acordo com a teoria da integração de Bela Balassa (1962). A primeira refere-se a continuar com uma União Aduaneira imperfeita, o que garante benefícios a alguns setores industriais, mas impede a inserção global do Brasil, bem como acesso a novos mercados mais competitivos. A segunda é a de retorno à etapa de integração anterior de Área de Livre Comércio, que faria com que determinados setores perdessem preferências comerciais na região, mas que no longo prazo poderiam se beneficiar de um aumento de produtividade brasileira diante da maior pressão às firmas internas e disciplina da atividade econômica decorrente da concorrência acirrada. Somase a essa opção, potenciais ganhos de competitividade à economia brasileira, além de ter acesso a novos mercados com os quais o Brasil não conseguiria negociar conjuntamente com os demais Estados-membros do Mercosul.

Trata-se esse de um trade off para a integração comercial e produtiva brasileira, refletido em uma espécie de path dependence, pois em virtudes de decisões nacionais combinadas com decisões regionais e eventos internacionais da primeira década e meia deste século, o Brasil foi restringindo suas opções de parceiros comerciais e, por conseguinte, de opções de inserção externa, deixando de participar ativamente de processos produtivos internacionais de alcance global.

É importante destacar, a despeito das críticas ao bloco, dois papéis desempenhados pelo Mercosul na década de 1990 como suporte para a transição da crise para a estabilidade brasileiro na visão do professor Burges (2013). Segundo o autor, o Mercosul foi basilar no processo de manutenção da abertura comercial unilateral implementada pelo governo Collor, "ao ancorar as reformas em compromissos externos", e como estágio para a construção de um mercado regional, o qual servia como "um estímulo adicional para a permanência das reformas econômicas que vinham se tornando cada vez mais importantes para a estabilidade doméstica e para o ingresso nos mercados globais" (BURGES, 2013).

No tocante ao alargamento de membros do Mercosul, o ingresso da Venezuela, assim como o da Bolívia em curso, e provável ingresso do Equador trazem ganhos ao Mercosul em termos de tamanho de mercado, de abrangência geográfica, e melhor acesso ao mar do Caribe. Esse alargamento regional reforça o bloco sul-americano enquanto instituição para promoção da integração regional, e possível posição de 
barganha nas negociações internacionais. Contudo, como afirma o professor Eduardo Viola, "o governo venezuelano tem uma orientação oposta ao livre comércio, à competitividade global, à integração de cadeias produtivas transnacionais e ao que originalmente era o Mercosul" (IPEA, 2012). Dadas às orientações dos governos desses países em termos de política externa, dotadas de certo antiamericanismo e relutantes a Tratados de Livre Comércio, bem como a maior intervenção estatal na economia doméstica, dificultam-se as negociações futuras do Brasil para acesso a novos mercados, ou mesmo que faça com que o Brasil passe por dificuldades na promoção de reformas ortodoxas na economia doméstica.

Há também outra espécie de trade off adicional ao Brasil em termos de integração regional na América do Sul, referente aos efeitos à competitividade. No que concerne ao elemento da aquisição de conhecimento, know-how, e eficiência econômica, há uma espécie de "processo de aprendizado" que define ganhos de competitividade por estágios regionais de integração. Primeiramente, há a pretensão de ganhos de competitividade de mercado em nível regional, para somente após consolidar-se nesse estágio, buscar-se a inserção econômica em mercados mais competitivos. Segundo Baumann (2013c), essa é a opção do Brasil. Contudo, os Estados-membros do Mercosul (sobretudo com o seu atual alargamento) não são relativamente bem dotados de exportações de alto conteúdo tecnológico e de conhecimento. Além disso, o Brasil baseia-se mais no mercado regional e menos em mercados mais competitivos, do que agem outros emergentes como China e Índia, que inseriram suas economias nos dois estágios concomitantemente (BAUMANN, 2013c). O grande fator complicador na opção brasileira, segundo Baumann (2013c), é o risco de que as exportações para o mercado regional não superem o estágio de aprendizado inicial para a competição mais acirrada com mercados desenvolvidos.

A integração regional como alavanca para a integração na economia global foi uma das grandes estratégias seguidas por China e Alemanha no pós-guerra, por exemplo, mesmo que tenham apresentado processos distintos ou mesmo que não tenha sido a orientação política inicial. A China promoveu um modelo de crescimento via exportações com as zonas econômicas especiais (ZEE), as quais forneciam atrações à atividade privada como a isenção de impostos e menores custos de produção (BALDWIN, 2012; BACHA; BAUMGARTEN, 2013). Ao longo do tempo tornou-se um dos hubs regionais, na medida em que os vizinhos menores como Vietnã e Tailândia se inseriram nos clusters regionais de produção. Já a Alemanha promoveu ums 
reestruturação no pós-guerra com grandes investimentos em $\mathrm{P} \& \mathrm{D}$, e influxo de trabalhadores de países de economia de transição. Até o grande crescimento chinês no século XXI, a Alemanha era o maior exportador mundial, muito em virtude também da integração produtiva na Europa Ocidental. Ao promoverem esforços para a integração produtiva regional - e não somente a busca pelos superávits comerciais -, e utilizando-se da "atuação dupla" descrita acima (regional e global), os dois países conseguiram liderar uma harmonização do ciclo de negócios regional, tornando-se hubs de suas respectivas regiões (BALDWIN, 2013).

O não confinamento à América do Sul por parte do Brasil foi, inclusive, uma recomendação do Diretor-Geral da OMC, Roberto Azevedo, ao declarar em entrevista à Revista Época em março de 2014, que o Brasil deve buscar acesso a novos mercados para futuros ganhos de competitividade. Além de tentar ingressar em outros mercados que não o regional, Azevedo recomendou a abertura do mercado brasileiro, sob o argumento de que "modelos fechados tendem a não ser sustentáveis, a gerar ineficiência e falta de competitividade", e que o "comércio exterior deve ser um elemento de desenvolvimento de qualquer país" devendo este ser pensado em perspectiva de longo prazo (AZEVEDO, 2014) ${ }^{47}$.

\section{c) A Questão da Soberania no Mercosul}

Os Estados modernos frente ao processo de aceleração da globalização "procuram geralmente proteger a sua soberania - o direito de governar - e sua autonomia - a capacidade de escolher formas apropriadas de desenvolvimento político, econômico e social" (HELD; MCGREW, 2003, p. 11). Parte da literatura acadêmica (ROSECRANCE, 1999; KEOHANE; NYE, 1977; LAIDI, 2012) destaca que países de tamanho continental, como Rússia, Brasil, Índia, e China tendem a adotar perfis

\footnotetext{
47 "O comércio exterior deve ser um elemento de desenvolvimento e estratégia econômica de qualquer país, mas não pode ser pensado no curto prazo. Tem de fazer sentido no longo prazo. Poucos economistas, hoje, argumentariam que a forma de adquirir competitividade é fechar o mercado e fornecer ao consumidor doméstico, na esperança de que assim você desenvolva a tecnologia e a capacidade necessárias para ser competitivo. Pelo contrário. A gente vê é que modelos fechados tendem a não ser sustentáveis, a gerar ineficiência e falta de competitividade. A abertura do mercado brasileiro e de outros mercados para os produtos brasileiros é importante para qualquer estratégia de ganho de competitividade. Pelas dimensões do país, por nosso parque produtivo, pelo agronegócio, o Brasil não pode se confinar a uma região geográfica. Tem de atingir mercados no mundo inteiro, para escoar essa produção. É uma maneira de desenvolver a competitividade". (AZEVEDO, 2014, grifo nosso).
} 
soberanistas no sistema internacional, portanto, com grande resguardo da autonomia nacional.

É sabido em decorrência da vasta literatura acadêmica econômica, política e de relações internacionais que a integração econômica - seja regional, global, ou ambas impacta em restrições à autonomia e possivelmente à soberania de Estados que optem por essa inserção externa, em diferentes níveis e conforme a profundidade da integração. Importante alegar que essas restrições não significam necessariamente perda de bem estar social ou eficiência econômica (ainda que no discurso político, sejam argumentos amplamente utilizados), mas apenas a 'possibilidade' de governos conduzirem políticas de intervenção, por exemplo, políticas macroeconômicas anticíclicas nacionais (embora, como argumenta Estevadeordal, as exportações possam ser utilizadas para esse propósito).

A falta de avanços em termos de integração econômica na América Latina, em especial na América Sul, pode ter suas bases também na histórica falta de renúncia de parte da soberania no que concerne a suas políticas macroeconômicas, principalmente em matéria de política industrial e comercial (ALMEIDA, 2013a). A efetiva integração econômica regional depende essencialmente de estratégias e concertos que não sejam unicamente nacionais apartadas. Por vezes, por exemplo, governos evitam desvalorizar sua taxa de câmbio com o intuito de não prejudicar o Estado vizinho, o que poderia gerar déficits comerciais e até suscitar dúvidas quanto à sustentabilidade da integração.

Para Almeida (2013d), a soberania nacional e a integração regional são aparentemente termos contraditórios, seja em termos gerais ou específicos. Segundo o autor, em um processo de tomada de decisão, o desejo por preservar a soberania nacional é colidente com o engajamento em processos de integração econômica; por outro lado, a condição indispensável para a integração - abertura recíproca das economias em termos de liberalização comercial com parceiros selecionados obriga os países a renunciar "as mais importantes alavancas da soberania exclusiva sobre certas políticas públicas" (ALMEIDA, 2013 d, p. 471 - 472, tradução nossa).

É justamente em razão do desejo pela manutenção plena da soberania e autonomia brasileira e seu resguardo frente a uma autônoma dinâmica decisória da integração, que o Brasil apresenta, nas palavras de Vigevani e Aragusuku (2014), "baixa disposição quanto ao fortalecimento institucional do Mercosul, já que o estado não deseja perder o controle do processo". Para os autores, a lógica da posição brasileira no 
bloco está mais voltada "à expansão do bloco do que propriamente ao seu aprofundamento" (VIGEVANI; ARAGUSUKU, 2014, p. 171).

Experiências nacionais do pós-Segunda Guerra indicam que mesmo que um país esteja até mesmo em situações de rivalidade intensa, nas quais se exige um resguardo maior da soberania nacional, é possível (e muitas vezes recomendável) abrir-se a importações, desenvolver-se via exportações e investimentos estrangeiros, e participar ativamente de projetos de integração regional produtiva. O caso da Coreia do Sul é considerado exemplar. O Estado sul-coreano ainda vive tecnicamente em situação de guerra com a vizinha Coreia do Norte desde 1953, quando o conflito foi encerrado por um armistício e não um Tratado de Paz. Em 2012, as importações de bens e serviços do país superaram o valor de mais da metade de seu PIB; em 2013, a corrente comercial do país superava o próprio PIB (109\%); e o país é dentre os países do G20 o que possui maior parcela de valor estrangeiro adicionado às suas exportações, em cerca de $40 \%$ das suas exportações finais, segundo dados do ano de 2009, último ano disponível (OECD; WTO, 2013).

Esses indicadores poderiam ser interpretados perante a visão nacionalista ou mercantilista da economia política internacional como fontes de vulnerabilidade e sensibilidade do país em relação a eventos exógenos à jurisdição nacional, bem como limitadores a uma política de desenvolvimento autônomo. No entanto, o país é uma das treze economias que superaram a "armadilha da classe média" (middle-income trap) segundo estimativas do Banco Mundial (2012). De 101 economias de média-renda em 1960, somente Grécia, Hong Kong, Irlanda, Israel, Japão, Ilhas Maurício, Portugal, Cingapura, Espanha, Taiwan, e a própria Coreia do Sul tornaram-se economias de alta renda até 2008 (AGENOR; CANUTO; JELENIC, 2012; WORLD BANK, 2012). Países árabes como Arábia Saudita, Emirados Árabes, Kuwait, Catar e Bahrein também alcançaram feito aproximado, devido à gigantesca renda das exportações de petróleo. Todos esses países adotaram em alguma medida uma economia no modelo outwardoriented, embora que de distintas formas e combinadas com reformas internas, seja se beneficiando de uma sustentável exportação que foi revertida em investimentos internos, ou de inserção em processos de integração econômica regional.

Importante destacar que o "trauma da guerra" pode ter sido um fator motivador ou de necessidade para a flexibilização das soberanias nacionais para o projeto de integração mais profunda que deu origem à União Europeia, na medida em que os laços comerciais se aprofundaram e passaram a trabalhar após décadas de inclusões de novos 
Estados-membros, a fim de evitar também novos conflitos, e visaram construir uma integração de prosperidade econômica e social. Esse trauma não existe na mesma intensidade na região sul-americana como há no continente europeu, e pode vir a gerar uma acomodação regional quanto à necessidade de abdicação de parte da soberania nacional, o que é improvável em uma região cujo histórico de pacificidade, de reativismo em termos de política externa, e de componente ideológico forte parecem prevalecer.

Para Almeida (2013d), apesar de muitas vezes o esquema de integração regional europeu ser utilizado como padrão para os projetos de integração na América Latina, a União Europeia adotou um esquema supranacional de integração de forma que políticas regionais fossem implementadas de forma independente da vontade aleatória de governos nacionais, enquanto que os esquemas de integração latino-americanos estão voltados ao modelo intergovernamentalista, o qual pode conviver com pressões domésticas contrárias ao interesse regional de longo prazo.

Há, sobretudo, um dilema inerente à integração via modelo intergovernamental. Como afirmam Vigevani e Aragusuku (2014, p. 271), "na medida em que resguarda um alto nível de autonomia para o Estado nacional, faz com que este tenha uma forte capacidade de intervenção em relação à política de integração regional". Para os autores, esse modelo seria compatível "com o elemento da autonomia de política exterior do Brasil", mas não necessariamente com o aprofundamento institucional do Mercosul.

Cabe destacar que o critério da supranacionalidade institucional não seria garantia para o Mercosul, por exemplo, alcançar o objetivo de construção de um mercado comum, pois este depende em grande parte do cumprimento dos governos nacionais dos compromissos firmados nos tratados formalmente assinados, além do desmantelamento das barreiras para a integração econômica (ALMEIDA, 2013d, p. 482- 483). Em resumo, para Almeida: "Irrespective of the political structure, and of national political sovereignty over (at least parts of) macroeconomic policies and some sectoral policies (especially industry, trade, and agriculture), it is unlikely that a real integration process can thoroughly succeed". (ALMEIDA, 2013d, p. 481).

Venables e Winters (2004, p. 101), nesse sentido, ao discorrerem sobre a integração econômica hemisférica americana sob a perspectiva da integração mais profunda da União Europeia, relatam que o compromisso político e $\mathrm{o}$ supranacionalismo são elementos fundamentais para o sucesso de longo prazo de um 
projeto de integração, mas que estes também não estavam explicitamente contidos nas negociações da ALCA:

(...) the EU performance is grounded in the deep political commitment of its members and in the creation of a political and institutional framework that can pursue integration and regional reform independently of national governments. It is in these dimensions that the Americas are most fundamentally different from the European Union, and the possibility of following the European model is most limited. (VENABLES; WINTERS, 2004, p. 101).

Na América do Sul, as duas maiores economias, Brasil e Argentina, não souberam lidar com essa flexibilização da soberania nacional (ALMEIDA, 2013 d). O embaixador Samuel Pinheiro Guimarães argumenta justamente em prol dos termos da soberania nacional e desenvolvimento autônomo, inclusive, para declinar ou não apoiar as negociações em curso de um acordo do Mercosul com a União Europeia. Conforme suas palavras na revista Carta Maior em artigo intitulado "A União Europeia e o fim do Mercosul", "o eventual acordo UE/Mercosul será o início do fim do Mercosul e o fim da possibilidade de desenvolvimento autônomo e soberano brasileiro e do (seu) objetivo estratégico de construir um bloco econômico e político na América do Sul, próspero, democrático e soberano" (GUIMARÃES, 2014).

Estevadeordal e Suominem (2009) justamente descrevem os acordos comerciais como "remédios para a soberania" no mundo globalizante. Os autores partiram de discursos do primeiro ministro britânico da Segunda Guerra Mundial, Sir. Winston Churchill, ao ensejar que o estreitamento de laços econômicos ajudaria a tornar uma região mais pacífica e a reduzir rivalidades nacionais, visto que as nações cederiam parte de sua soberania em prol de um bem regional comum. O embaixador Sérgio Amaral descreve também nesse sentido que a motivação política da integração europeia fez com que a liberalização comercial e de investimentos fosse implantada como um instrumento para "a construção de uma comunidade de interesses entre países destruídos por duas grandes guerras" (AMARAL, 2013, p. 25). Para o embaixador, o Brasil ainda carece de uma visão estratégica que motive e guie o país em matéria de comércio exterior e de integração. 


\section{d) A Emergência da Aliança do Pacífico e o Contraste com o Mercosul}

Nos assuntos mais atuais ligados aos rumos da economia mundial e novos regionalismos, a Aliança do Pacífico é uma das novas iniciativas de institucionalização de um bloco comercial. Baseada em um conjunto de objetivos com foco no mercado, com amplo número de assinaturas prévias de TLCs (Tratados de Livre Comércio), a Aliança do Pacífico visa à integração da economia de seus países membros - Chile, Colômbia, México e Peru. A iniciativa para a formação do bloco surge em 2010 pelo então presidente peruano Alan García Pérez, o qual estendeu o convite aos presidentes de Chile, Colômbia, Equador e Panamá para a conformação de uma Área de Integração Profunda. Objetivando formar uma articulação política, econômica, de cooperação e integração, o bloco tem como base a projeção de maior competitividade dos países membros para a região da Ásia-Pacífico, a região que mais cresce em dinamismo comercial e financeiro no globo (MEXICO, 2012).

O Equador não respondeu ao convite do presidente peruano - o que em parte pode estar relacionado com a sua aproximação de outros blocos menos liberalizantes como a ALBA e o Mercosul -, enquanto que o Panamá respondeu, e foi acordado que este participasse na qualidade de observador. Chile e Colômbia expressaram o desejo de que na iniciativa participasse também o México - que compartilha de elementos econômicos e políticos pró-comércio aos demais três países -, proposta aceita pelo Peru (MEXICO, 2012).

Na Declaração de Lima de 28 de abril de 2011, primeiro documento formal do bloco, os presidentes dos quatro países estabeleceram que, em uma primeira etapa, se trabalhasse nos temas seguintes: a) Movimentos de pessoas, de negócios e facilitação para o trânsito migratório, incluindo a cooperação policial, a ser coordenado pelo México; b) Comércio e integração, incluindo facilitação de comércio e cooperação aduaneira, a ser coordenado pelo Chile; c) Serviços e capitais, incluindo a possibilidade de integrar as bolsas de valores, a ser coordenado pela Colômbia; e, d) Cooperação e mecanismo de solução de diferenças, a ser coordenado pelo Peru ${ }^{48}$.

A Aliança do Pacífico avança em termos de consolidação de personalidade jurídica após o dia 6 de junho de 2012, por meio da assinatura do Acordo Marco do bloco, reforçada pela Declaração Presidencial de Paranal em Antofagasta, Chile, na qual

\footnotetext{
${ }^{48}$ Disponível em: 〈http://alianzapacifico.net/documents/AP_Declaracion_Lima_I_Cumbre.pdf〉. Acesso em: 20 mar. 2015.
} 
os presidentes reforçam o desejo pela promoção de comércio, serviços e investimentos entre os países ${ }^{49}$. A formação do novo bloco despertou a atenção da comunidade internacional e interesse transcontinental. Até o primeiro trimestre de 2015, a AP possuía trinta Estados observadores dos cinco continentes: (Oceania) Austrália, Nova Zelândia; (América do Sul) Uruguai, Paraguai, Equador; (América Central) Costa Rica, El Salvador, Guatemala, Honduras, República Dominicana, Trinidad y Tobago; (América do Norte) Estados Unidos e Canadá; (África) Marrocos; (Europa) Alemanha, Bélgica, Espanha, Finlândia, França, Itália, Países Baixos, Portugal, Reino Unido, Suíça; (Oriente Médio) Israel e Turquia; e (Ásia) China, Cingapura, Índia e Japão ${ }^{50}$. Um traço comum desses países, à exceção de China e Honduras, e utilizando-se dos conceitos de Viola e Leis (2007), é a posição não confrontacionista em termos de política externa com a hegemonia das democracias de mercado. Para efeito de comparação, o Mercosul, o qual possui mais de 20 anos de existência, possui apenas dois Estados Observadores: México e Nova Zelândia.

A Aliança do Pacífico obteve avanços importantes em pouco tempo de existência, apesar da não concretização institucional e registro na "tábua-lei" da OMC. Com a possível inclusão da bolsa de valores mexicana ao MILA - Mercado Integrado Latino Americano, o qual já inclui os mercados de capitais dos outros três membros da AP, tal programa consistirá na maior bolsa de valores da América Latina, ultrapassando a Ibovespa. A formação do Conselho Empresarial também se configura como um grande avanço, visto que os empresários possuem grande espaço para negociações dentro do bloco, ao lado das articulações existentes entre as agências promotoras de exportações de Chile, México, Colômbia, e Peru. Do ponto de vista da coordenação e representação política-comercial, criou-se embaixadas conjuntas e escritórios de negócios dos quatro países no exterior.

O destaque recebido pela Aliança do Pacífico também advém do crescimento apresentado nos últimos anos pelos países constituintes originários, mesmo em época de recuperação econômica global:

In a time when regional and global economies continue to rebound from the
2008 global recession, the Pacific Alliance countries enjoyed economic
growth topping 5 percent last year (2012)-even as Mercosur's economies
grew by half as much. In the aggregate, the members make up the seventh-

\footnotetext{
${ }^{49}$ Disponível em: <http://alianzapacifico.net/documents/Declaracion_de_Paranal.pdf>. Acesso em 20 mar. 2015.

50 SITE ALIANZA DEL PACÍFICO. Disponível em: <http://alianzapacifico.net/paises/paisesobservadores/>. Acesso em 20 mar. 2015.
} 
largest economy in the world. And per capita gross domestic product (GDP) is a high US\$15,000 (MEACHAM, 2013).

O novo bloco comercial possui como requisitos políticos essenciais à participação como membro pleno o reconhecimento da Democracia e Estado de Direito, formalmente exposto no artigo II do Acordo Marco: a) a vigência do Estado de Direito, da Democracia e das respectivas ordens internacionais; b) a separação dos poderes do Estado; e c) a proteção, a promoção, respeito e garantia dos direitos humanos e as liberdades individuais. De fato, os quatro países constituintes (Chile, Colômbia, México e Peru) sinalizam a um regime político democrático, mesmo que em diferentes níveis, ao mesmo tempo em que mantêm relações amistosas com as democracias de mercado consolidadas do Norte.

A emergência da Aliança do Pacífico, de lógica integracionista contrastante com a do Mercosul, tem sido apontada como produto dos laços dos quatro Estados-membros - Chile, Peru, Colômbia e México com os Estados Unidos, com o qual os quatro países possuem tratados de livre comércio assinados previamente à formação do bloco latinoamericano. Em 2013, na ocasião em que os EUA tornaram-se Estado observador da AP, o US Department of State saldou a iniciativa como exemplo para os países latinoamericanos, além de destacar o compartilhamento de valores como o compromisso com a abertura comercial, e extensão dos vínculos econômicos existente com Chile, Peru e México nas negociações da Parceria Trans-Pacífico (US DEPARTMENT OF STATE, $2013)^{51}$.

Do ponto de vista de orientação econômico-comercial, os países da Aliança possuem uma visão mais aberta da globalização, e mais liberalizante em termos comerciais e financeiros em comparação aos demais países latino-americanos. Além disso, possuem uma considerável estabilidade institucional, com sociedades democráticas $^{52}$. Tais aspectos apontam para uma evolução dos ambientes de democracia

\footnotetext{
51 "The United States applauds the progress the Pacific Alliance has made to integrate its markets and the strong economic policies pursued by its members as examples for Latin America. We intend to use our observer status to recognize and support these achievements and to advance the values we share with the member states, including commitments to expanding free markets, reducing inequality, opening trade, and welcoming foreign investment. The United States already enjoys strong and productive economic relations and a free trade agreement with each Pacific Alliance member country. Our participation as an observer is a natural extension of those existing economic relationships and our cooperative efforts under the Trans-Pacific Partnership with Alliance members Chile, Peru, and Mexico". (US DEPARTMENT OF STATE, 2013).

${ }_{52}$ A democracia no México e na Colômbia acaba sendo em parte degradada pelo narcotráfico e ação coerciva do Estado na tentativa de resolver o problema. Direitos como o de locomoção, de ir e vir, bem como liberdade de tráfego entre as fronteiras acabam sendo em parte naturalmente restringidos.
} 
de mercado (com destaque ao Chile), a qual combina um regime político democrático com um sistema econômico de economia de mercado (VIOLA; LEIS, 2007).

Um dos propósitos originais do Mercosul era o princípio do "regionalismo aberto", prevalecente na América Latina nos anos 1990, o qual pressupõe que uma abertura aos mercados globais seria mais vantajosa se combinada com a criação de um profundo mercado regional, assim, objetivando economias de escala (THE ECONOMIST, 2011a). Para o embaixador brasileiro Luiz Felipe Lampreia, ex-ministro das relações exteriores do Brasil, o Mercosul desviou-se de seus objetivos originais:

(...) o Mercosul desviou-se da sua concepção original de projeto de integração comercial e econômica e hoje é quase que somente uma frente política. Há fortes tendências protecionistas internas que frequentemente colidem com os propósitos originais do próprio Mercosul (LAMPREIA, 2012).

A Aliança do Pacífico em seu site oficial expõe que uma das características do bloco - que a torna uma plataforma estratégica e indica o modelo do regionalismo aberto em sua integração - é o fato de que "busca conformar un proceso de integración abierto y no excluyente, constituido por países con visiones afines de desarrollo y promotores del libre comercio como impulsor del crecimiento ${ }^{53}$ ".

A revista The Economist (2013) relata uma divisão do continente latinoamericano em dois blocos econômicos alternativos, de visões diferentes: o Mercosul com uma visão mais estatista, e a Aliança do Pacífico com uma visão mais voltada ao mercado. Os dois maiores parceiros brasileiros no Mercosul, Argentina e Venezuela apresentam baixo crescimento, economias corriqueiramente controladas e intervindas pelo Estado, e protecionismo comercial (BBC, 2011; ALMEIDA. 2013a).

Do ponto de vista teórico, uma utilização do conceito de "efeito dominó" no regionalismo (BALDWIN, 1996 apud Hoekman; Kostecki, 2010) é um suporte na explicação de como o contraste ao Mercosul pode ter influenciado a formação da Aliança do Pacífico. Segundo Hoekman e Kostecki - os quais se baseiam dos estudos de Baldwin sobre a integração regional - "quando os principais parceiros comerciais criam ou assinam blocos comerciais, as pressões sobre os outros a seguir o modelo aumentam, e os custos da exclusão parecem crescer (2010, p.348)”'. Com uma análise adaptada da passagem acima, a movimentação dos demais países na região latino-

\footnotetext{
53 Valor estratégico. Aliança del Pacífico. Disponível em <http://alianzapacifico.net/que_es_la_alianza/valor-estrategico/> Acesso em 20 de agosto de 2013. Acesso em: 20 dez. 2014.
} 
americana em torno de uma ideologia mais próxima de um nacionalismo econômico (em até certo ponto, "anti-imperialismo", como no caso da ALBA) e de intervencionismo pode ter influenciado o Chile, a Colômbia, o México e o Peru a se unirem à nova onda de regionalismo, mas com uma integração dotada de outra coerência ideológica, mais liberal, relativamente mais próxima dos países desenvolvidos.

Fatores essencialmente políticos e estratégicos podem estar por trás da emergência da Aliança do Pacífico, em razão das coalizões comerciais e sociopolíticas que estavam em andamento na América Latina. Há uma resistência dos quatro países Chile, Colômbia, México e Peru - a se integrarem a outros blocos da região ou intensificarem seus laços com os já adeptos (como o caso da Colômbia e Peru que fazem parte da Comunidade Andina - CAN) por razões de incoerências ideológicas e divergências de orientações de política externa. O fato de os quatro países da Aliança terem grandes laços políticos e econômicos com os Estados Unidos aumenta a resistência e contraste em relação a outros grupos da região, já que, por exemplo, a Venezuela - líder da ALBA e incorporada no Mercosul - adota uma postura confrontacionista ao sistema de segurança internacional baseado nas democracias de mercado ocidentais, que possui o Estados Unidos como eixo central (VIOLA; LEIS, 2007).

Indicadores econômicos internacionais corroboram o contraste entre os países dos dois blocos econômicos. Os três quadros abaixo apresentam a colocação geral dos indicadores de cada país da Aliança do Pacífico, do Mercosul, e de Bolívia e Equador, países que encontram-se em algum processo de adesão ao Mercosul.

A instituição The Heritage Foundation em parceria com Wall Street Journal realiza anualmente um ranking de 178 países de acordo com o grau de liberdade econômica - um dos critérios para se mensurar o grau de uma economia de mercado -, cobrindo 10 liberdades distribuídas em quatro categorias: rule of law (direitos de propriedade, liberdade contra corrupção), governo limitado (liberdade fiscal, gastos governamentais), eficiência regulatória (liberdade de negócios, liberdade de trabalho, liberdade monetária), e open markets (liberdade comercial, liberdade de investimento, liberdade financeira). Tendo o Uruguai como exceção (em boa parte em razão de sua democracia bem consolidada) de país bem ranqueado dentre os membros do Mercosul, os países da Aliança do Pacífico estão em melhor posição que o bloco vizinho. O Chile destaca-se em nível não só regional, ocupando que ocupa a $7^{a}$ colocação mundial em 
liberdade econômica (HERITAGE data, 2015). A Venezuela encontra-se na antepenúltima posição dentre os 178 países analisados, à frente somente de Cuba $\left(177^{\mathrm{a}}\right)$ e Coreia do Norte $\left(178^{\mathrm{a}}\right)$.

Quadro 3 - Liberdade Econômica - AP e Mercosul

\begin{tabular}{c|c|c|c}
\hline $\begin{array}{c}\text { Posição } \\
\text { mundial }\end{array}$ & AP & Mercosul & \\
\hline 7 & Chile & & \\
\hline 28 & Colômbia & & \\
\hline 43 & & Uruguai & \\
\hline 47 & Peru & & \\
\hline 59 & México & & \\
\hline 83 & & Paraguai & \\
\hline 118 & & Brasil & \\
\hline 156 & & & Equador \\
\hline 163 & & & Bolívia \\
\hline 169 & & Argentina & \\
\hline 176 & & Venezuela & \\
\hline
\end{tabular}

Fonte: Heritage Index of Economic Freedom - 2015.

Com o objetivo de medir a facilidade de se fazer de negócios, o Banco Mundial e a International Finance Corporation divulgam um índice anual Doing Business referente a 189 países. Os indicadores agregados utilizados são: abertura de empresas, obtenção de alvarás para construção, obtenção de eletricidade, registro de propriedades, obtenção de crédito, proteção de investidores, pagamento de impostos, comércio entre fronteiras, execução de contratos e resolução de insolvência. Nesse indicador, todos os países constituintes da Aliança do Pacífico encontram-se melhor ranqueados do que todos os países membros do Mercosul (WORLD BANK data, 2014). Assim como no índice de liberdade econômica, o Uruguai é o melhor posicionado quanto ao melhor ambiente de negócios dentre os países do Mercosul.

Quadro 4 - Ambiente de Negócios - AP e Mercosul
\begin{tabular}{c|c|c|c}
\hline $\begin{array}{c}\text { Posição } \\
\text { mundial }\end{array}$ & AP & Mercosul & \\
\hline 34 & Colômbia & & \\
\hline 35 & Peru & & \\
\hline 39 & México & & \\
\hline 41 & Chile & & \\
\hline 82 & & Uruguai & \\
\hline 92 & & Paraguai & \\
\hline 115 & & & Equador \\
\hline 120 & & Brasil & \\
\hline 124 & & Argentina & \\
\hline 157 & & & Bolívia \\
\hline 182 & & Venezuela & \\
\hline
\end{tabular}

Fonte: World Bank, Doing Business - 2015. 
Elaborado pelo Fórum Econômico Mundial e instituições parceiras, o Índice de Competitividade Global (IGC) aborda 12 categorias pilares da competitividade de cada nação: infraestrutura, ambiente macroeconômico, saúde e educação primária, educação de nível superior e treinamento, eficiência do mercado de bens, eficiência do mercado de trabalho, sofisticação do mercado financeiro, preparo tecnológico, tamanho do mercado, sofisticação empresarial e inovação (WEF, 2015). De acordo com o The Global Competitiveness Report 2014-2015, o Brasil encontra-se na 57 posição mundial, possuindo apenas o Chile dentre os países do quadro abaixo à sua frente. À exceção do Brasil, os países da Aliança do Pacífico estão em melhor posição em comparação com os demais países do Mercosul. A Venezuela situa-se na $131^{\text {a }}$ posição dentre os 144 países analisados no ranking geral de competitividade global.

Quadro 5 - Índice de Competitividade Global - AP e Mercosul

\begin{tabular}{c|c|c|c}
\hline $\begin{array}{c}\text { Posição } \\
\text { mundial }\end{array}$ & AP & MERCOSUL & \\
\hline 33 & Chile & & \\
\hline 57 & & Brasil & \\
\hline 61 & México & & \\
\hline 65 & Peru & & \\
\hline 66 & Colômbia & & Equador \\
\hline 71 & & & \\
\hline 80 & & Uruguai & \\
\hline 104 & & Argentina & \\
\hline 105 & & & Bolívia \\
\hline 120 & & Paraguai & \\
\hline 131 & & Venezuela & \\
\hline
\end{tabular}

Fonte: World Economic Forum.*A colocação do Equador refere-se ao relatório do ano 2013-2014, pois o país não foi incluído na edição 20142015 por inconsistência dos dados.

Os três quadros analisados dizem respeito apenas a indicadores que consideram os países individualmente. No entanto, para uma verdadeira integração, é necessária uma harmonização regulatória e integração produtiva entre os países membros de um acordo regional. Estevadeordal (2014) acredita que a Aliança do Pacífico apresenta uma atualização em relação às novas dinâmicas econômicas. De acordo com o autor:

A Aliança do Pacífico é importante não apenas por sua representatividade econômica, mas também pela ambição de seus objetivos, os quais vão além do desmantelamento das barreiras tradicionais ao intercâmbio de bens e serviços. O escopo da Aliança trata tanto da redução de barreiras quanto da atualização de regras, promovendo simultaneamente o desenvolvimento dos setores produtivos do bloco e o reforço das cadeias regionais de valor (ESTEVADEORDAL, 2014, p. 22). 
Entretanto, os desafios para a integração dos países da AP também não devem ser pormenorizados e não há garantias de que o bloco consiga materializar sua agenda audaciosa. A existência prévia de diversos acordos entre os Estados membros e destes com outros países podem limitar o crescimento do comércio intrarregional. Há também restrições estruturais para a complementaridade produtiva entre seus Estados-membros, diante da concentração de bens primários no perfil exportador de Chile, Colômbia e Peru. Além disso, Colômbia e México convivem com os problemas de segurança decorrentes do tráfico de drogas, o que degrada o ambiente democrático e pode inclusive ensejar a imposição de barreiras à livre circulação de bens, serviços e pessoas.

Para o Brasil, os efeitos da emergência da Aliança do Pacífico podem não ser positivos ao propósito da liderança regional ou mesmo à estratégia brasileira de integração sul-americana (MENEZES, 2014). A divisão da América do Sul em torno de dois projetos distintos de integração tende a indicar que o Brasil carece de representatividade e apoio ao seu projeto autonomista de integração e que o Mercosul necessita de uma atualização em seu plano de aprofundamento de integração. A aproximação dos dois blocos, proposta pelo Chile presidido por Bachelet, pode criar oportunidades conjuntas de integração, mas os contrastes políticos permanecem. Além disso, o ambiente favorável aos negócios e ao setor privado nos países-membros da AP do que o proporcionado pelos vizinhos sul-americanos, bem como a participação de Chile, México e Peru nas negociações do TTIP e TPP (a Colômbia já manifestou o desejo de adesão) (ESTEVADEORDAL, 2014) podem gerar desvio de comércio e de investimentos dos países-membros do Mercosul. Isso, contudo, só o tempo dirá.

\subsection{O Comércio Intrarregional}

O Assessor Especial para Assuntos Internacionais da Presidência da República, Marco Aurélio Garcia, relata em seu artigo A Opção Sul-americana (2008) que há duas opções de atuação do Brasil no contexto de um mundo multipolar e de emergência de potência regionais: a atuação solitária, ou a atuação via integração e cooperação com os vizinhos. De acordo com o professor, o Brasil escolheu a segunda opção (GARCIA, 2008). A integração sul-americana é a prioridade da política externa brasileira, sobretudo desde 2003 (GARCIA, 2008; AMORIM, 2010; BURGES, 2013; SPEKTOR, 2010). 
De fato, por seu gigantismo geográfico e peso econômico regional, o Brasil deve buscar dirimir eventuais atritos diplomáticos e ajudar na provisão de bens públicos regionais. Entretanto, o principal bloco de integração regional em termos comerciais, o Mercosul, pode não representar ao Brasil a relevância em termos de ganhos econômicos, de competitividade ou mesmo de aquisição tecnológica no nível correspondente dos esforços políticos envidados para sua promoção pela política comercial brasileira.

Uma dimensão desse fato pode ser tomada a partir da tabela abaixo, desenvolvida por Estevadeordal (2012) a partir dos dados da UM Comtrade, que mostra a variação do comércio intrarregional como percentual das exportações de membros de um bloco entre si, e com o resto do mundo para os anos de 2010, além da taxa de variação do mesmo indicador em relação ao ano de 1990. São analisados dados de nove blocos de integração e/ou agrupamento de países: LAC - "latin-american countries"; Mercosul; NAFTA; Comunidade do Caribe - CARICOM; Sistema de la Integración Centroamericana - SICA; EUA + Canadá; União Europeia - 27 países; região da ÁsiaPacífico; e ASEAN.

Tabela 3 - Comércio intrarregional (\% das exportações) em 2010 (as células em negrito apresentam os fluxos de comércio intrarregionais)

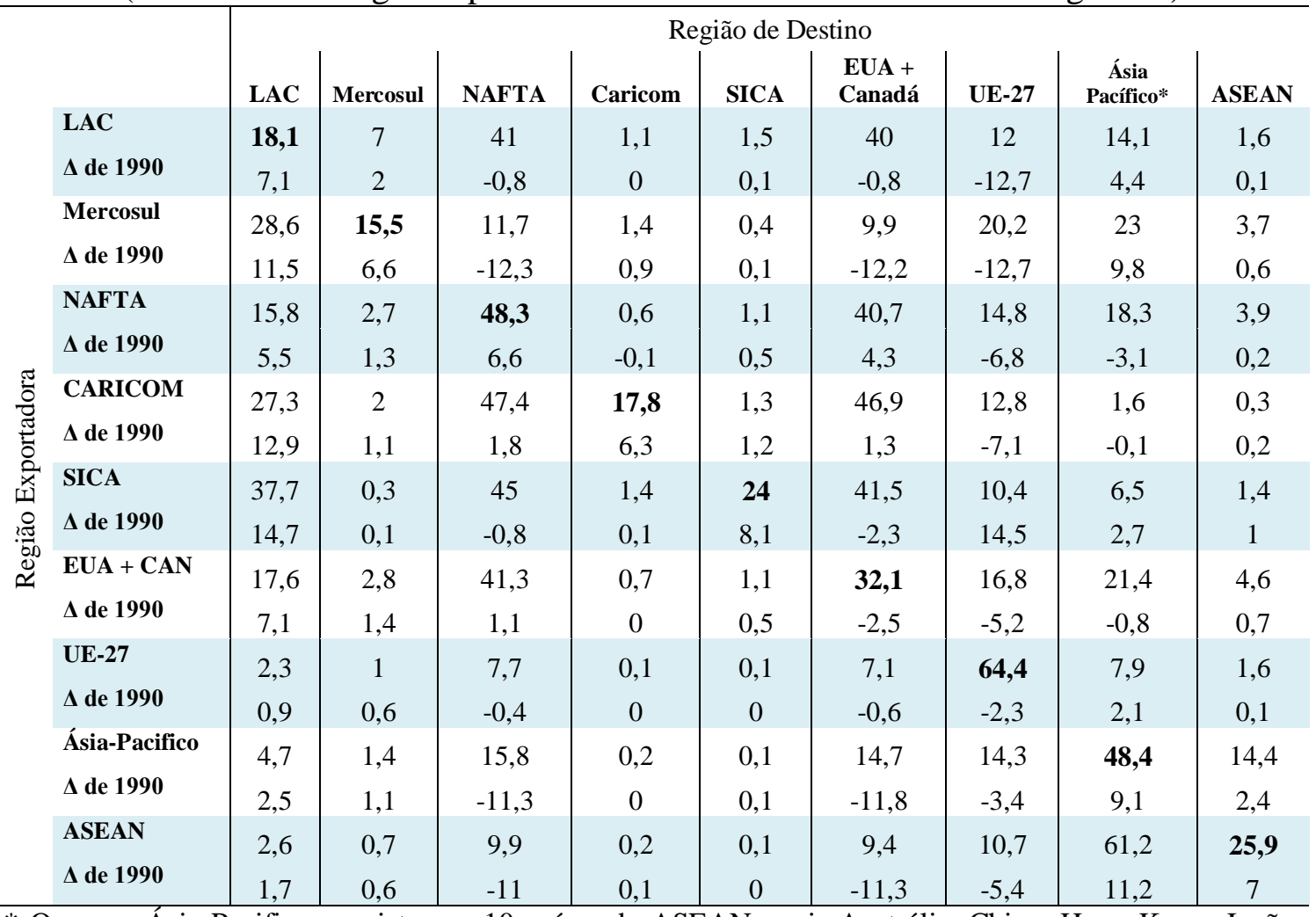

* O grupo Ásia-Pacifico consiste nos 10 países da ASEAN, mais Austrália, China, Hong Kong, Japão, Coreia do Sul, Nova Zelândia, e Taiwan.

Fonte: ESTAVADEORDAL (2012), com base no U.N. COMTRADE data (2012). 
Há aspectos relevantes em termos de mudanças dos fluxos comerciais entre as regiões apresentadas. A transição de poder do Atlântico para o Pacífico e do Ocidente para o Oriente descrita por Joseph Nye em The Future of Power (2011), pelo menos em termos comerciais, é evidenciada pelo maior aumento da variação positiva do comércio intrarregional verificado na região Ásia-Pacífico em comparação com as demais regiões analisadas $(9,1 \%$ em relação a 1990).

A América Latina foi a região para a qual o Mercosul apresentou a maior variação percentual positiva de 1990 a 2010 como destino de suas exportações (11,5\%). A região da Ásia-Pacífico foi a segunda com 9,8\%, seguida do próprio Mercosul com variação de 6,6\%. Todavia, o Mercosul apresentou variações significativamente negativas do percentual de suas exportações para os Estados Unidos e o Canadá (juntos, $-12,2 \%)$, e União Europeia (-12,7\%). Esse pode ser interpretado como um dado preocupante para ganhos de competitividade para o Brasil e demais países do Mercosul. Os mercados norte-americano e europeu são muito mais competitivos do que os mercados encontrados no Mercosul e América Latina, e também concentram maior conteúdo de inovações tecnológicas e manufatureiras. Devido a maior possibilidade de aquisição de conhecimento e de potenciais ganhos de competitividade econômica, perder parcela de mercado em países mais desenvolvidos e aumentar a mesma em mercados menos desenvolvidos pode influir em perda de oportunidades para a inserção mais efetiva nas cadeias globais de valor e sustentabilidade da produção industrial brasileira. Conforme descreve Bonomo (2014, p. 6), "O mercado interno não é mais suficiente para assegurar o crescimento e as aspirações de desenvolvimento econômico do país, em particular do setor industrial. (...) O Brasil precisa, com urgência, de novos mercados".

Há de se enfatizar o baixo comércio intrarregional do Mercosul comparativamente aos demais blocos e agrupamentos. O bloco sul-americano ocupa a última colocação no quesito dentre as regiões analisadas. Destacam- se o alto valor de comércio intrarregional da União Europeia, da Ásia-Pacífico e do Nafta, as três regiões onde se concentram as principais cadeias globais de valor: $\left(1^{\circ}\right) 64,4 \%$ - UE; $\left(2^{\circ}\right) 48,4 \%$ - Ásia-Pacífico; $\left(3^{\circ}\right)$ 48,3\% - NAFTA; $\left(4^{\circ}\right)$ 25,9\% - ASEAN; $\left(5^{\circ}\right) 24 \%$ - SICA; $\left(6^{\circ}\right)$ 18,1\% - LAC; $\left(7^{\circ}\right)$ 17, 8\% - CARICOM; ( $\left.8^{\circ}\right)$ 15,5\% - Mercosul. Parte da argumentação para esse baixo percentual de comércio intrarregional do Mercosul é a de que o bloco possui baixa participação como destino das exportações totais brasileiras. 
Cerca de um quinto das exportações do Brasil são destinadas à região da América Latina e Caribe. Em 2014, o Mercosul respondia apenas por 11,1\% como destino das exportações e $8,1 \%$ das origens das importações brasileiras, conforme quadro abaixo (SECEX data, 2015), com valores arredondados a um dígito decimal.

Tabela 4 - Principais mercados de origem das exportações e das importações do Brasil

\begin{tabular}{ccccccc}
\hline & \multicolumn{3}{c}{ EXPORTAÇÕES } & \multicolumn{3}{c}{ IMPORTAÇÕES } \\
\hline \multirow{2}{*}{ REGĨ̃O } & \multirow{2}{*}{ VALOR } & $\begin{array}{c}\text { VAR. \% } \\
\text { Ásia }\end{array}$ & \multirow{2}{*}{ PART. \% } & VALOR & $\begin{array}{c}\text { VAR. \% } \\
\text { PART. }\end{array}$ \\
& 73.513 & $-5,3$ & 32,7 & 71.168 & $-2,8$ & 31,1 \\
\hline América Latina e Caribe & 46.045 & $-14,0$ & 20,5 & 37.578 & $-7,9$ & 16,4 \\
\hline - Mercosul & 25.054 & $-15,2$ & 11,1 & 18.446 & $-9,8$ & 8,1 \\
\hline - Demais da AL e Caribe & 20.991 & $-12,6$ & 9,3 & 19.132 & $-5,9$ & 8,4 \\
\hline União Europeia & 42.047 & $-12,0$ & 18,7 & 46.713 & $-8,0$ & 20,4 \\
\hline Estados Unidos & 27.144 & 9,2 & 12,1 & 35.299 & $-2,7$ & 15,4 \\
\hline Oriente Médio & 10.419 & $-4,9$ & 4,6 & 7.999 & 8,5 & 3,5 \\
\hline África & 9.701 & $-12,5$ & 4,3 & 17.061 & $-2,2$ & 7,4 \\
\hline Europa Oriental & 4.583 & 9,7 & 2,0 & 3.961 & 10,1 & 1,7 \\
\hline
\end{tabular}

Fonte: MDIC/Secex (2015).

No entanto, nota-se pela composição da pauta exportadora do Brasil por regiões de destino (conforme a figura 15) que há uma concentração de exportações de produtos industriais para o mercado regional. Cerca de $72 \%$ das exportações do Brasil para a América Latina e Caribe são compostas por manufaturas, porcentagem muito acima do mesmo indicador em relação às outras regiões. Além da proximidade geográfica, os acordos preferenciais de comércio no âmbito da ALADI explicam o diferencial de valor. Cabe destacar que essa concentração pode não favorecer o crescimento das exportações do Brasil de bens de alto valor agregado. A América Latina e Caribe conjuntamente correspondem a apenas a $6 \%$ do PIB global, mas absorve mais de $38 \%$ das exportações totais de manufaturados do Brasil (Secex data, 2015; BAUMANN, 2013a, p. 174). A região possui potencial limitado para a sustentabilidade do comércio de bens e serviços de longo prazo e da expansão das exportações brasileiras de manufaturados. 
Figura 14 - Participação percentual das exportações do Brasil

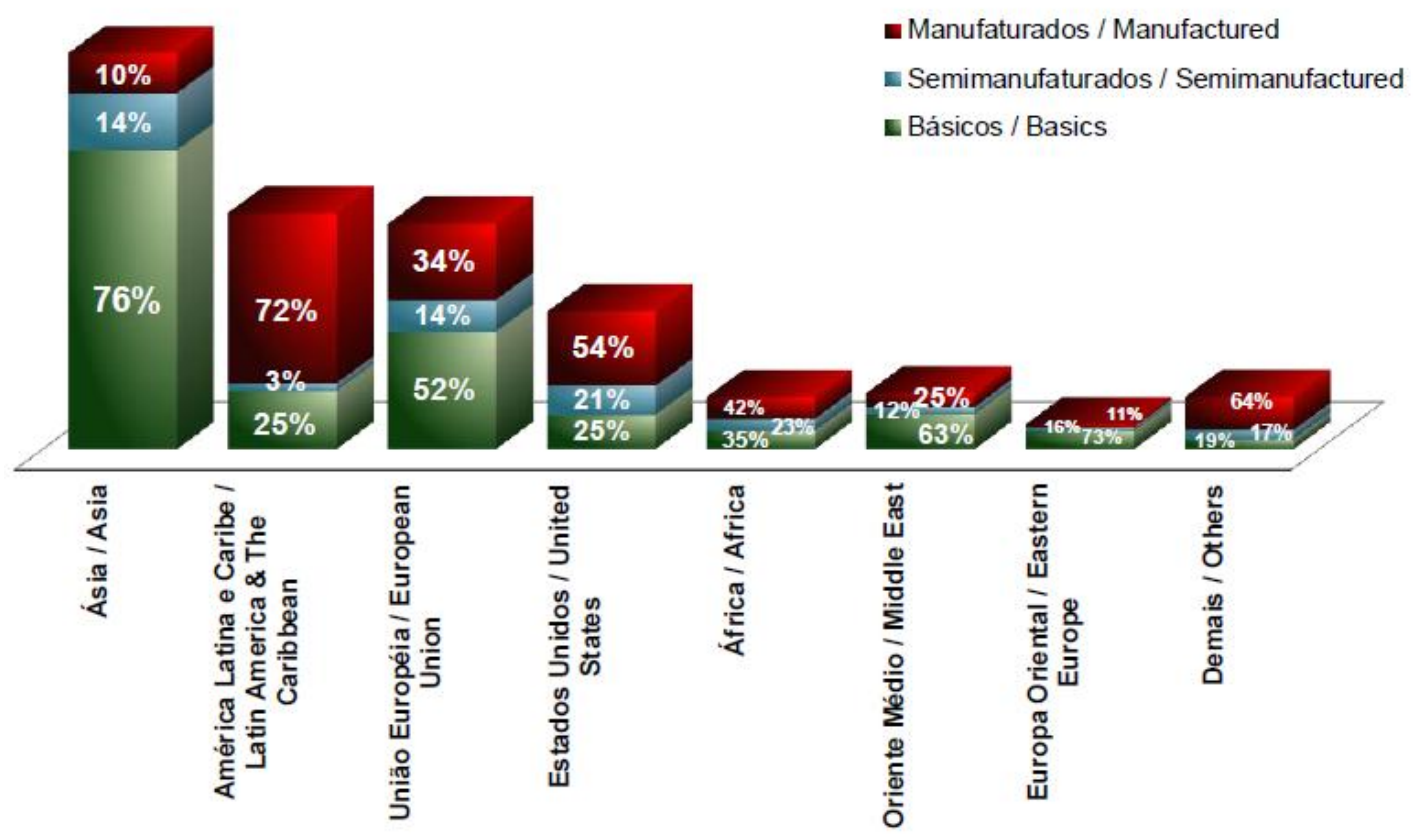

Fonte: MDIC/Secex (2014) Disponível em: 〈http://www.mdic.gov.br//arquivos/dwnl_1423144482.pdf〉. Acesso em: 10 abr. 2015.

Há também uma recorrente preocupação com a importação de produtos a baixo custo da China no mercado regional tradicionalmente brasileiro. Conforme Editorial do Jornal O Globo, os acordos assinados entre Argentina e China em âmbitos variáveis, como para o setor de telecomunicações, setor agrícola e hidrelétrico podem vir a ser uma moeda de troca do governo chinês a fim de uma abertura por parte da Argentina aos seus produtos via preferência tarifária (O GLOBO, 2015), o que pode prejudicar as exportações de manufaturados do Brasil.

De fato, há uma crescente penetração de importações não só na Argentina, mas nos países do Mercosul de produtos chineses (AMARAL, 2014). O quadro abaixo mostra uma taxa de aumento consideravelmente superior das importações dos demais países do Mercosul - Argentina, Uruguai, Paraguai e Venezuela - provenientes da China em relação ao Brasil para os anos de 2009 e 2013. 
Tabela 5 - Importações dos demais países do Mercosul provenientes do Brasil e da China em 2009 e $2013^{54}$

\begin{tabular}{cccrccccc}
\hline \multicolumn{2}{c}{ BRASIL } & & \multicolumn{2}{c}{ CHINA } & \multicolumn{3}{c}{$\begin{array}{c}\text { Taxa de } \\
\text { crescimento } \\
\text { percentual }\end{array}$} & $\begin{array}{c}\text { Diferença de } \\
\text { percentual } \\
\text { aproximada }\end{array}$ \\
\hline & \multicolumn{2}{c}{2009} & 2013 & 2009 & 2013 & Brasil & China \\
\hline Argentina* & 11.819 .000 .000 & 19.161 .000 .000 & 4.843 .000 .000 & 11.341 .000 .000 & 162 & 234 & 72 \\
\hline Uruguai & 1.459 .789 .544 & 3.546 .073 .000 & 819.105 .073 & 3.255 .866 .000 & 125,7 & 239,9 & 114 \\
\hline Paraguai & 1.526 .868 .553 & 2.899 .919 .801 & 810.397 .669 & 1.689 .905 .801 & 189,9 & 208,5 & 19 \\
\hline Venezuela & 4.046 .030 .838 & 4.602 .803 .138 & 3.822 .499 .885 & 7.636 .995 .027 & 113,8 & 199,8 & 86 \\
\hline
\end{tabular}

Fonte: elaboração própria a partir das seguintes fontes de dados: Argentina: INDEC - Dirección Nacional de Estadísticas del Sector Externo; Uruguai: Banco Central del Uruguay (BCU); Venezuela: Ministerio del Poder Popular de Planificación del Gobierno Bolivariano de Venezuela; Paraguay - Servicio de Búsqueda de Negocios. Trade.Nosis.com. Obs.: Nos dados computados entre Argentina e China são incluídas as regiões autônomas Hong Kong e Macau.

A menor diferença de percentual de aumento das importações de bens e serviços chineses em relação às importações oriundas do Brasil é a do Paraguai, com 19\%, e a maior, do Uruguai, com $114 \%$ de diferença de taxa de crescimento percentual. Esses dados relativos contrastam com o aparente sucesso do aumento de comércio entre os Estados-membros do Mercosul no período pós-crise, conforme defendido pelo exministro Antônio Patriota (Conf. PATRIOTA, 2013). Todos os quatro países apresentaram um aumento de mais de $100 \%$ de importações de bens provenientes do Brasil, mas também apresentaram um crescimento de mais de $200 \%$ de importações provenientes da China (considerado o arredondamento dos dados referentes à Venezuela).

Cabe a realização de um exercício lógico derivado do exemplo acima. Se o Estados-membros do Mercosul elevaram em maior proporção suas importações de origem chinesa do que de origem brasileira, é possível imaginar que a situação não seja tão diferente em outros mercados ao redor do mundo com os quais o Brasil não possui acordo comercial. Em outras palavras, se esse fenômeno ocorre na região de parceiros tradicionais do Brasil, e inseridos em um bloco relativamente protegido por uma alta tarifa externa comum e onde a economia brasileira é a mais competitiva, é possível que as exportações do País estejam também sob risco - provavelmente em maior grau do

\footnotetext{
${ }^{54}$ Os valores de cada país correspondem a fontes distintas, e em virtude disso, podem apresentar algumas distorções entre os países no padrão de mensuração do comércio. Contudo, essas diferenças são pormenorizadas perante o objetivo de ressaltar a diferença de aumento das importações de cada um dos outros quatro países-membros do Mercosul com o Brasil em comparação com a China.
} 
que no Mercosul - em outros mercados com os quais o Brasil ainda não possui acordos relevantes.

\subsection{Padrões de Liderança em uma Integração Econômica Regional}

Apesar dos esforços brasileiros e criações institucionais (como a Unasul) o desígnio - mesmo que não explícito - de constituição de uma liderança regional parece não ter sido bem sucedido. O Brasil detém os critérios objetivos, como seu gigantismo territorial e maior economia da América Latina, porém carece de elementos subjetivos relacionados ao reconhecimento e aceitação ampla de sua liderança. Os esforços brasileiros em busca da obtenção de um assento permanente no Conselho de Segurança das Nações Unidas, por exemplo, não tem sido ou não foram apoiados pelos países vizinhos como Argentina e Colômbia. Adicionalmente como descreve Spektor (2010, p. 29), "[n] a vizinhança, a percepção dominante em relação ao Brasil é a de que o país, apesar de ser o principal centro de poder regional, não traduz essa ascendência em liderança amigável". A própria diversidade de orientações de inserção externa no subcontinente, seja globalista, bolivariana, ou reticente, não facilitou a consolidação do Brasil como líder regional em seu sentido político em torno de seu projeto de integração autônomo (ALMEIDA, 2013 d) ${ }^{55}$. A emergência da Aliança do Pacífico também vem a desafiar e a contrapor projetos distintos de integração na região (como já descrito na subseção 3.2).

Em matéria econômica, a América do Sul tem sido um mercado central para as exportações brasileira de manufaturados, absorvendo mais de $38 \%$ das exportações totais do Brasil do mesmo tipo de bens (MDIC/SECEX, 2015). No entanto, parte das explicações para essa concentração residem na adoção da tarifa externa comum no

\footnotetext{
55 No mesmo sentido, Almeida (2013) descreve: "Brazil was actively entrepreneurial in all those endeavors, aiming to establish a kind of "regional leadership" which, in fact, was never accepted by the neighboring countries" (p. 489). De acordo com Domingues (2013), "ao longo do governo Lula o contexto regional não pareceu receptível à aspiração de liderança brasileira Ao longo do governo Lula o contexto regional não pareceu receptível à aspiração de liderança brasileira. (...) a convergência liberal dos anos 1990 foi substituída por uma fragmentação política nos anos 2000. A diversidade de programas de desenvolvimento e estratégias de inserção internacional dificultou a construção de um projeto regional comum." (DOMINGUES, 2013, p. 98). Não é o objetivo desta dissertação adentrar os motivos dos percalços para a constituição da liderança brasileira na América do Sul. Para isso, recomenda-se a dissertação de Reinaldo Domingues defendida em 2013: DOMINGUES, Reinaldo Alencar. O Perfil do Brasil como Potência Regional Sul-Americana no Governo Lula (2003-2010). 2013. 108 f. Dissertação (Mestrado em Relações Internacionais) - Universidade de Brasília, Brasília, 2013.
} 
Mercosul. Há autores que descrevem que a TEC serviria ao propósito de criação de uma "reserva de mercado", sobretudo no mercado automobilístico, e diante disso o comércio regional não seria necessariamente reflexo de uma competitividade das exportações brasileiras (THORSTENSEN, 2014; BONOMO, 2014, p. 6). Contudo, cabe destacar que, por mais que o Mercosul seja a principal zona de preferência comercial para as exportações do Brasil, essa reserva de mercado tem sido insuficiente para conter o crescimento de importações provenientes de outras regiões pelos demais países membros do bloco.

Para Thomaz Zanotto, Diretor do Departamento de Relações Internacionais e Comércio Exterior (DEREX) da FIESP, "o Brasil reúne as qualidades políticas e econômicas necessárias para liderar o processo de abertura comercial do bloco, bem como a consolidação institucional deste" (p. 9). Além disso, como propõe Zanotto, é essencial reestabelecer, o que em suas palavras é "a regra de ouro" do Tratado de Assunção, a "livre circulação de bens, serviços e fatores produtivos" na região (ZANOTTO, 2014, p. 9-10). A restauração do processo de abertura comercial contínua no Mercosul, bem como o cumprimento das normas tornam-se indispensáveis para a inserção externa competitiva e sustentável da economia conjunta de seus membros.

No tocante ao aos novos padrões de comércio, um aspecto central relacionado às cadeias globais de valor é o seu forte componente geográfico, tendo sua origem em âmbito regional via mecanismos como complementaridade produtiva e acordos preferenciais de comércio e investimento (BALDWIN, 2013; ELMS; LOW, 2013). Uma implicação lógica dessa afirmação é a de que os exercícios para a integração às CGV em termos de adicionar valor ao comércio não dependem unicamente de estratégias nacionais, mas também, e talvez mais importante, de estratégias regionais ou mesmo supranacionais de integração.

Esse padrão de integração tende a conformar duas tendências na economia mundial aparentemente contraditórios: regionalização e globalização (IAPADRE; TAJOLI, 2014). A constante regionalização representa a proliferação de acordos comerciais que impulsionam processos de integração regional. A segunda tendência não é nova, mas claramente aprofundou-se no século XXI. Cabe destacar que esse é um conceito excessivamente utilizado em pesquisas e noticiários devido à facilidade com que resume diversos e complexos processos em curso. Como destacam Held e McGrew (2003, p.4), a globalização pode ser caracterizada com a expansão de escala, de 
magnitude, de aceleração e de impacto aprofundado de fluxos de pessoas, ideias, comércio, investimentos inter-regionais.

Em termos objetivos, dois fenômenos caracterizam a globalização em termos comerciais: o aumento de número de parceiros comerciais de cada país - e nesse aspecto o Brasil se destaca como um global trader, devido ao alto número de parceiros comerciais (embora a intensidade dos fluxos seja muito distinta); e o aumento das distâncias percorridas dos fluxos comerciais ao longo do tempo, devido à redução dos custos de transporte e comunicação (IAPADRE; TAJOLI, 2014).

Com o adensamento das parcerias comerciais entre Estados, há a formação de distintas formas de relações que refletem a posição da maior economia em questão com as economias menores, estabelecendo assim distintos padrões de liderança. Esses padrões são definidos por Iapadre e Tajoli (2014) como: "export hub" - quando a preferência da economia maior para o comércio intrarregional é maior para importações do que exportações. Esse modelo de liderança tende a ser resultado de redes de produção regionais, onde "a importância como mercados de destino para o resto da região é maior do que sua dependência das exportações intrarregionais", e os "produtos finais de $h u b$ feitos de fatores ou bens produzidos em diferentes spokes são exportados pelo país hub para o resto do mundo" (IAPADRE; TAJOLI, 2014, p. 95). Nota-se que esse modelo tende a produzir um efeito "multiplicador regional" (BAUMANN; NG, 2012; BAUMANN, 2013a), o qual pressupõe uma demanda derivada decorrente da seguinte situação: um aumento da demanda de bens finais do país hub gera um aumento automático da demanda de bens intermediários, bens de capital, serviços e outros fatores de produção dos países spokes.

O outro tipo de liderança econômica regional é o de "local supplier", do qual é possível denotar uma ideia de uma integração regional mais "introspectiva", da qual seria mais difícil aspirar à inserção global competitiva de seus membros. Ao contrário do modelo "export hub", para os líderes no padrão "local supplier", o comércio intrarregional é maior para suas exportações do que importações. Em outras palavras, a região para o líder tende a ser um mercado para exportações do líder e este é menos dependente das importações intrarregionais do que para os líderes "export-hub". De acordo com Iapadre e Tajoli (2014, p. 95), " [t]his can be the result of the leader country attracting foreign direct investment and related imports of intermediate goods, which are used to produce final goods for the entire regional market". O Brasil experimenta um padrão de liderança mais próximo do modelo "local supplier" (IAPADRE; TAJOLI, 
2014), o que em parte justifica o grau de concentração das exportações de manufaturas para o mercado regional. Entretanto, esse não é um modelo que torne mais sustentável as trocas comerciais na região.

Além de ser um modelo de liderança produtiva regional mais "virtuoso" quanto ao elemento da demanda derivada e crescimento regional, o modelo export hub ajuda a tornar a integração e as trocas comerciais entre os Estados mais sustentáveis no longo prazo e com possíveis maiores gerações de emprego e de renda (BAUMANN; NG, 2012). Nota-se que nesse tipo de integração, a economia maior deve orientar a modelo de integração para a harmonização e facilitação dos ciclos de negócios em nível regional, e não necessariamente a busca pelo superávit comercial. A Alemanha, por exemplo, desperta críticas em relação aos crescentes superávits do país com os demais membros da União Europeia, o que poderia vir a prejudicar no longo prazo o balanço de pagamento dos vizinhos menores (BERNANKE, 2015). Mas nesse caso, os superávits advêm do alto conteúdo tecnológico e elevado grau de transformação contidos nas exportações alemãs no comércio intrarregional, diferentemente do caso brasileiro na América do Sul.

\subsection{A Integração Latino-Americana e a do Leste Asiático: Experiências Destoantes}

O Leste Asiático mesmo padecendo por um longo tempo de uma "lacuna organizacional" (CALDER; FUKUYAMA, 2012) obteve um alto grau de interdependência econômica e produtiva da região, sendo um dos três grandes polos de cadeias produtivas no mundo ao lado da América do Norte e da União Europeia (BALDWIN; LOPEZ-GONZALES, 2012). Conforme aponta Baumann (2013a), um dos principais problemas para a integração latino-americana é o fluxo inverso e tortuoso de bens intermediários. No Leste Asiático há um movimento circular, um processo autossustentável, no qual os países centrais importam bens de produção dos países menores, e exportam para esses países e para o resto do mundo bens finais. Na América Latina, "as economias grandes exportam bens de produção para as economias menores e importam delas basicamente produtos primários" (BAUMANN, 2013a, p.291).

Há grandes diferenças das experiências de integração regional latino-americana e asiática e uma grande discrepância em termos de resultados. A ideologização da política econômica (PALMA, 2013) e a politização da integração (LOPES, 2011) 
muitas vezes apenas reproduzem discursos e não necessariamente avaliam os ganhos econômicos, e com isso podem elevar os problemas estruturais para uma integração de fato na América Latina. Cabe destacar que, deferentemente do que é registrado na América Latina onde se ensaia por décadas um desenvolvimento autônomo, a integração econômica do Leste Asiático possui um maior grau de autonomia econômica, o que ajudou a região a captar soluções internas para problemas econômicos.

Há também alguns fatores de ordem interna aos países latino-americanos no que se refere à condução de políticas macroeconômicas os quais influem diretamente no plano de integração e desenvolvimento regional. O professor Gabriel Palma (2013), da Universidade de Cambridge, relata três razões para o fato de a América Latina não ter demonstrado crescimento sustentado como o Leste Asiático. A primeira está relacionada à taxa de investimento privado, "que é de $30 \%$ do PIB na Ásia, enquanto que, na América Latina, é de 15\%". A segunda é relacionada ao ritmo das reformas, pois segundo Palma, no Leste Asiático era comum a realização da liberalização econômica e financeira de forma pragmática, lenta e seletiva, o que dá tempo aos agentes econômicos se adaptarem às mudanças. Há também a avaliação de Giambiagi e Almeida que descrevem que muitas reformas não foram realizadas com a profundidade requerida ou mesmo não tiveram a continuidade após a estabilidade macroeconômica (GIAMBIAGI; ALMEIDA, 2003). O terceiro fator está relacionado com que Palma diz ser uma "ilusão do mundo das finanças". Segundo o professor, na América Latina há uma crença de que a economia pode crescer independentemente do que ocorra com a economia real, a exemplo dos investimentos, da produtividade e das mudanças tecnológicas ${ }^{56}$ (PALMA, 2013).

Além das reformas, é importante destacar que os aspectos geográficos também são fundamentais na definição de uma cadeia produtiva e na avaliação das diferenças entre as regiões. A América do Sul possui acidentes geográficos como a cordilheira dos Andes, e obstáculos naturais, como a Floresta Amazônica, o que dificulta a implementação de um projeto como o IIRSA e demanda maiores cuidados com impactos ambientais na execução de projetos de infraestrutura. Enquanto isso, os países do Leste Asiático estão ligados e ao mesmo tempo separados por mares, o que reduz custos de transporte e incentiva a construção de grandes e eficientes zonas portuárias.

\footnotetext{
${ }^{56}$ No quarto capítulo, tem-se os níveis de taxa de investimento nos principais emergentes, com resultados distintos para países asiáticos e latino-americanos.
} 
No Leste Asiático, há uma incidência expressiva de comércio regional em bens intermediários, indicadores importantes de um processo produtivo. Esse comércio que gerou um processo de integração produtiva e comercial possibilitou uma crescente homogeneidade entre as economias da região, bem como concerto no ciclo de negócios, e até nas estratégias de desenvolvimento. Exemplo disso é a descrição de Baldwin (2011, p. 10) sobre a interdependência na região ao citar o sucesso chinês como plataforma exportadora, o que na sua visão, não poderia ser explica sem adentrar nas políticas adotadas pelos vizinhos:

Of course China-specific factors also matter, but if you want to fully understand Chinese export success, you have to look at the productive factors, technology, and government policies of Japan, Korea, Taipei, and ASEAN nations - that is where many of the critical components, and most of the design, marketing, and management expertise lie (BALDWIN, 2011, p. 10).

Essa experiência interdependente e integrada é algo muito distante da realidade latino-americana. Depois de mais de seis décadas de esforços de promoção da integração regional, a América Latina não observou grandes avanços relativos em matéria de integração econômica produtiva. Para a construção de uma integração via complementaridade produtiva que possa um dia atingir um processo semelhante a uma cadeia regional de valor adicionado, políticas adotadas pelo Brasil de forma isolada não são suficientes, pois os vizinhos também deveriam se comprometer com o processo. Uma dessas ações envolve a abdicação parcial das soberanias nacionais em matéria econômica para o bem comum regional, o desenvolvimento conjunto com ganhos de competitividade internacional. 


\section{CAPÍTULO 4 - A POLÍTICA COMERCIAL EXTERNA BRASILEIRA E AS DINÂMICAS DA ECONOMIA GLOBAL}

Após a descrição da globalização contemporânea que deu origem às Cadeias Globais de Valor e demais transformações da economia global, do cenário internacional favorável à economia brasileira, bem como a análise dos dilemas do Mercosul para construir um caminho mais propício para a formação de uma cadeia regional de valor e perdas \& ganhos ao Brasil, faz-se necessário adentrar as questões centrais de opções de escolha brasileira no que tange à sua política comercial externa.

Destaca-se aposta quase absoluta do Brasil no multilateralismo, o que resultou no relativo isolamento do Brasil dos acordos comerciais. O resguardo da soberania e autonomia nacional são fatores limitadores tanto na assinatura de acordos de comércio, como na integração nas CGV. A estrutura de proteção comercial do Brasil é elevada comparada às tarifas adotadas pelos demais emergentes, bem como é muito baixa a participação do comércio sobre o PIB, que em conjunto afetam negativamente a competitividade industrial e inserção internacional brasileira.

\subsection{A Política Externa Brasileira e o Isolamento do Brasil dos Acordos Comerciais}

A política externa brasileira desde 2003 tem sido caracterizada por muitos analistas por um grande ativismo. Desde então, o governo brasileiro engajou-se em política externa em prol do assento permanente do país no Conselho de Segurança das Nações Unidas, algo muito improvável de acontecer nos próximos anos, segundo a maioria dos analistas; buscou-se também converter o país em líder regional, embora, como já foi dito no capítulo anterior, não tenha sido um objetivo explícito; priorizou-se as relações ditas Sul-Sul; institucionalizou-se o grupo IBAS, com África do Sul e Índia; e apostou-se em grande medida no multilateralismo comercial, à espera de um "multilateralismo de reciprocidade", exemplificado na atuação do país na quinta Reunião Ministerial da OMC em Cancun, e na subsequente formação do G-20 (CERVO, 2008; VIOLA; AYLLON, 2006).

Os resultados práticos dessas opções de política externa durante o governo Lula são discutíveis. Contudo, há de se destacar que havia um grande engajamento do Brasil no cenário internacional. Entretanto, uma mudança quanto ao ativismo seria verificada no terceiro governo federal petista. De acordo com Cervo e Lessa (2014), a política 
externa de Dilma em seu primeiro mandato (2011-2014) seria marcada por um "declínio relativo de inserção internacional do Brasil", no qual eram inexistentes "conceitos operacionais com capacidade de movimentar sociedade e Estado em torno de estratégias de ação externa", e havia "obstáculos acumulados pelo Estado com perda de eficiência de função gestora de caráter indutor" (CERVO; LESSA, 2014, p. 133-134). Entretanto, outros fatores podem ter contribuído para a mudança na política externa, como por exemplo: o declínio no crescimento da economia brasileira; a erosão da credibilidade do país após a desastrada tentativa do acordo nuclear com o Irã; e o menor interesse da presidente Dilma pelos assuntos internacionais em comparação ao presidente Lula.

Em matéria estritamente comercial não se verificou grandes mudanças na política externa brasileira do governo Lula e do primeiro governo Dilma. Somado a isso, como afirma Marcelo de Paiva Abreu (2015) em artigo para o jornal O Estado de São Paulo, "[a] política externa sob Lula desperdiçou a oportunidade de explorar o bom momento econômico para celebrar acordos relevantes. Ao final do seu governo, a participação do Brasil nas exportações globais ainda era menor do que a de 1928". O economista ainda adiciona ao declarar que "a medíocre política exterior pós-2010, que agora enfrenta momento de crise aguda, foi decorrência natural das políticas adotadas no governo Lula".

De fato, de 2003 a 2014, o Brasil não assinou nenhum acordo bilateral ou extrabloco no Mercosul com países de mercados mais sofisticados, e passou a adotar estratégias de negociações comerciais ineficazes. O economista Markwald (2013) compara o número de acordos comercial do Brasil com o de outras nações emergentes, e assim demonstra uma discrepância no número de acordos firmados, conforme a tabela abaixo. Enquanto demais nações emergentes adotaram papeis mais ativos na concretização de acordos preferenciais, o Brasil possuía em 2014 apenas cinco acordos notificados na OMC: ALADI; Mercosul; Mercosul-Índia; Protocol Trade Negotiations (PTN); e Sistema Geral de Preferências Comerciais (SGPC). De acordo com Markwald, quatro acordos firmados pelo Brasil não notificados na OMC estão em vigor: MercosulMéxico, Mercosul - Comunidade Andina, Mercosul - Turquia, e Mercosul - Israel (MARKWALD, 2013). 
Tabela 6 - Número de acordos comerciais em vigor assinados por emergentes selecionados

\begin{tabular}{|c|c|c|c|c|c|c|c|c|c|}
\hline \multirow{3}{*}{ País } & \multicolumn{7}{|c|}{ Acordos notificados na OMC (1) } & \multicolumn{2}{|c|}{ Acordos } \\
\hline & \multirow{2}{*}{$\begin{array}{c}\text { Total de } \\
\text { acordos } \\
\text { notificado } \\
\quad \text { s }\end{array}$} & \multicolumn{2}{|c|}{$\begin{array}{l}\text { Escopo de } \\
\text { acordo }\end{array}$} & \multicolumn{4}{|c|}{ Tipo de acordo } & \multirow{2}{*}{$\begin{array}{c}\text { Não } \\
\text { notificados } \\
\text { (2) }\end{array}$} & \multirow{2}{*}{$\begin{array}{c}\text { Em } \\
\text { negociação } \\
\text { (3) }\end{array}$} \\
\hline & & Bens & $\begin{array}{c}\text { Bens e } \\
\text { serviç } \\
\text { os } \\
\end{array}$ & $\begin{array}{l}\text { ALC e } \\
\text { AIE }\end{array}$ & ALC & $\mathrm{AEP}$ & UA & & \\
\hline Brasil & 5 & 4 & 1 & - & - & 4 & 1 & 4 & 9 \\
\hline China & 10 & 1 & 9 & 8 & - & 2 & - & 2 & 9 \\
\hline Índia & 15 & 11 & 4 & 4 & 4 & 7 & - & 7 & 10 \\
\hline Rússia & 16 & 16 & - & - & 14 & - & 2 & 1 & 2 \\
\hline $\begin{array}{l}\text { África do } \\
\text { Sul }\end{array}$ & 4 & 4 & - & - & 3 & - & 1 & 3 & 1 \\
\hline Chile & 24 & 6 & 18 & 18 & 2 & 4 & - & 8 & 3 \\
\hline México & 17 & 4 & 13 & 13 & 1 & 3 & - & 5 & 2 \\
\hline $\begin{array}{l}\text { Coreia do } \\
\text { Sul }\end{array}$ & 12 & 4 & 8 & 8 & 1 & 3 & - & 2 & 10 \\
\hline Turquia & 20 & 20 & - & - & 17 & 2 & 1 & s.d & 1 \\
\hline Indonésia & 8 & 4 & 4 & 3 & 3 & 2 & - & s.d & 9 \\
\hline
\end{tabular}

Fonte: MARKWALD, 2013. (1) Base de dados da OMC. (2) Naldin et al. (2013) para Brasil, China, Índia, Rússia e África do Sul. Informação coletada em sites para os demais países. (3) Asian Regional Integration Center/ADB para Austrália, China, Coreia do Sul, Índia e Indonésia, Thorstensen et al. (2013) para Brasil, Chile e México. Naldin et al. (2012) e informação de parceiros para Rússia, África do Sul e Turquia.

Notas: ALC - Acordo de Livre Comércio; AIE - Acordo de Integração Econômica; AEP - Acordo de Escopo Parcial; UA - União Aduaneira.

Nota-se a ausência de nações desenvolvidas e de grande mercado sofisticado nos acordos celebrados pelo Brasil. Dois acordos em negociação, com a União Europeia e com o Canadá, caso sejam concretizados, iriam em direção contrária a esse padrão de acordos firmados pelo país nos últimos anos. As arrastadas negociações entre o Mercosul e a União Europeia já duram mais de 15 anos,e forma iniciadas em 1999.Essa grande margem de tempo dificulta também o andar das negociações, já que os termos negociados mudam ao longo do tempo em razão das grandes mudanças na economia global $^{57}$. O número bastante reduzido de acordos preferenciais do Brasil com outras nações na comparação com os demais emergentes revela uma "desvantagem comparativa em termos de acesso a mercados para as nossas exportações" (AMARAL, 2013, p. 117),

Esse fator é um agravante para o setor industrial brasileiro, já que muitos dos potenciais competidores - em especial, os demais países emergentes - possuem relações preferenciais com os principais mercados globais, e muitos deles, já estão ou procuram adotar políticas para inserção nas cadeias globais de valor. O perfil industrialista e

\footnotetext{
${ }^{57}$ Há uma expectativa do governo brasileiro de que o Mercosul apresente uma proposta conjunta para a União Europeia em 2015.
} 
protecionista do Brasil dificulta a concessão em negociações comerciais. Segundo o professor Amado Cervo (2013), o Brasil no século XXI adotou uma "inserção industrialista", o que, apesar de não excluir a expansão do comércio exterior, "tem aversão pelos TLCs, entendendo que põem risco a vocação industrial, e prefere a ordem econômica traçada nas mesas de negociação multilateral, especialmente a OMC" (CERVO, 2013, p. 251).

A inserção de uma economia nas cadeias globais de valor também possui um forte componente de orientação de política externa. O embaixador Roberto Abdenur (2014; 2015) relata, por exemplo, que uma das razões pela reinserção da China na economia internacional após suas reformas e mercado deveu-se à aproximação do país com os vizinhos no início dos anos 1990, com os quais possuía relações marcadas por tensões e rivalidades. Outro exemplo da importância da política externa como mola propulsora dos ganhos do comércio mencionado pelo embaixador foi sua própria atuação entre 2004 e 2006 nas negociações comerciais junto ao Congresso americano. Segundo Abdenur, o objetivo era evitar a exclusão do Brasil do Sistema Global de Preferências Comerciais - SGP, ação esta coordenada com a Confederação Nacional da Indústria - CNI, a Federação das Indústrias de São Paulo - FIESP, e a Câmara Americana de Comércio Exterior - AMCHAM/Brasil.

A visão Norte-Sul da política internacional muitas vezes não representa a realidade atual de diferenças de força, poder e influência no cenário internacional contemporâneo, embora por muitas vezes seja utilizada para a divisão de responsabilidades com a Governança Global. As relações econômicas e de cooperação internacional possuem critérios de gradações de desenvolvimento nacionais que por muitas vezes necessitam de uma atualização ou mesmo superação da simplista clivagem Norte-Sul.

Com o crescimento econômico apresentado na década passada em grande parte baseado no ambiente internacional amplamente favorável, o Brasil tem sido impactado de forma passiva por revisões de critérios quanto ao auxílio para cooperação internacional. Grande exemplo disso é o fim da cooperação bilateral entre a União Europeia e o Brasil após 20 anos, anunciada pela UE em 2013. A União Europeia alocou $€ 50,8$ milhões no Estado brasileiro no período 2007-2013 como um "financing instrument for Development Cooperation (DCI)" (EUROPEAN COMISSION, 2013). No site da Comissão Europeia, a UE declara considerar o Brasil como um país "graduado" 
em seu desempenho econômico, justificando assim o fim da cooperação bilateral no âmbito do exercício financeiro no período 2014-2020:

\begin{abstract}
After more than 20 years of EU cooperation with Brazil, bilateral cooperation is coming to an end. Due to its economic performance, Brazil is considered as a "graduated" country and therefore it is not eligible for bilateral cooperation under the financial exercise 20142020. Brazil will remain eligible to participate in regional and thematic programmes. This provides an excellent opportunity to redefine together new forms of EU-Brazil cooperation. (EUROPEAN COMISSION, 2013, grifo nosso).
\end{abstract}

O modelo de governança que se baseia na classificação "dual" de países desenvolvidos (PD) e países em desenvolvimento (PEDs) ou o de países do Norte e países do Sul podem ser considerados uma das causas pelas quais outras organizações como a Asia- Pacific Economic Cooperation - APEC e acordos como o Protocolo de Kyoto não lograram a eficiência na gestão de seus objetivos. Isso decorre do fato de que, ao trabalhar com a lógica dual descrita entre PD e PEDs, estabelecem-se metas mais rígidas para aqueles e menos para estes. Entretanto, há acusações quanto a esse tipo de critério de estabelecimento de compromissos, em especial àqueles que criam margem para a existência de Estados "free-riders" (caronas) do lado dos países considerados em desenvolvimento. Esses seriam Estados que possuem economias graduadas em termos de desenvolvimento e que supostamente estariam se beneficiando das regras menos rígidas firmadas nas instituições internacionais, regras essas que seriam mais adequadas às nações com menor grau de desenvolvimento que os considerados "emergentes".

O que é factível é que a política externa de um país é um importante instrumento para a promoção do desenvolvimento nacional via construção de laços e acordos político-econômicos. Contudo, as estratégias de inserção internacional do Brasil desde 2003 apresentam limites quando se verifica os ganhos de margem atuação externa e de opções de inserção. A ênfase nas relações Sul-Sul, embora não seja contraditória com as relações com os países do dito Norte, a priorização nas negociações multilaterais na Organização Mundial do Comércio, e a defesa e manutenção do Mercosul de quadro regulatório ultrapassado e que limita as negociações de acordos do Brasil, viriam ajudar a marginalizar a economia brasileira dos acordos preferenciais de comércio (APCs) (ALMEIDA, 2013a; 2013b; MARKWALD, 2013; THORSTENSEN; FERRAZ, 2014) e do processo de fragmentação e dispersão geográfica da produção internacional. Portanto suscitariam o isolamento do Brasil das negociações dos Mega Acordos 
Comerciais - Parceria Transatlântica (TTIP) e Parceria Trans-Pacífico (TPP), e contribuiriam para a baixa participação do país nas Cadeias Globais de Valor (CGV). Embora tenha ganhado destaque como potência emergente no cenário internacional na primeira década do século XXI, o Brasil parece ter registrado um "déficit de realismo estratégico" quanto ao seu poder de barganha frente às nações desenvolvidas, bem como quanto à sustentabilidade do cenário econômico internacional favorável à sua economia $^{58}$.

\subsection{As Negociações dos Mega-Acordos e a Passividade Brasileira}

\section{a) A Aposta no Multilateralismo e a Estagnação da Rodada Doha}

Iniciada em 2001, a Rodada Doha da Organização Mundial do Comércio tem como um dos grandes objetivos a liberalização multilateral comercial de seus Estadosmembros, em especial, a favor dos países não desenvolvidos. A intenção da OMC era finalizar as negociações ao fim do ano de 2004. Contudo, devido à dificuldade com as controvérsias em temas relativos à agricultura, o ano de extensão foi movido para 2007 (ANDERSON NASH, p. 132). Até 2014 a Rodada não havia sido finalizada, e existem grandes dúvidas sobre a efetividade futura das negociações na organização.

O economista Spence (2010) argumenta que a rodada possui duas questões centrais a ser resolvidas. A primeira delas reside no seu escopo muito ambicioso e abrangente. O princípio single undertaking da organização determina que o pacote de acordos a ser negociado só será levado à sua assinatura e oficialização quando todos os países negociarem todos os acordos e chegarem a um consenso. A segunda se refere à sua alta complexidade derivada da alta quantidade de membros. Com o número crescente de países que integram a organização, as negociações tornam-se mais difíceis de alcançar um consenso e acordo macro.

O pacote de Bali, aprovado em dezembro de 2013, reacendeu as esperanças de avanço futuro na Rodada Doha. Trata-se do primeiro acordo firmado no âmbito da OMC passados quase vinte anos de sua formação. Do pacote o Acordo de Facilitação de Comércio é o mais relevante, o qual poderá gerar "uma redução de $10 \%$ dos custos de

\footnotetext{
${ }^{58}$ Exemplo disso são os casos de falta de pagamento de contas de luz e água em representações externas do Brasil em 2015 (MELLO; FLECK, 2015).
} 
comércio e gerar um incremento da renda mundial de até US\$ 1 trilhão" (RIOS; PANZINI, 2014, p. 41).

O que é notável nas negociações é o fato de que comumente países emergentes e pobres estão na dianteira da liberalização comercial de bens agrícolas, enquanto que os países desenvolvidos reivindicam a liberalização do setor de serviços, cada qual, em prol do setor no qual possui vantagens comparativas. Além disso, Spence questiona também a credibilidade futura da OMC: “A preocupação, principalmente nos países em desenvolvimento, não é apenas de que a rodada Doha fique indefinida, mas que a eficácia e a autoridade da OMC sejam prejudicadas a ponto de ela perder sua capacidade como guardiã da abertura global"' (SPENCE, 2010, p.139).

De fato, do ponto de vista de ganhos gerais do comércio, a liberalização multilateral é a mais benéfica, porém mais complexa. Segundo Anderson e Nash (2006, p. 126-127), "liberalization is a global public good, such that its benefits are not adequately internalized in the decision process of individual liberalizing countries". O risco de desvio de comércio, em contraponto à criação de comércio - tal como descrito por Jacob Viner - também é reduzido com o maior número de países envolvidos em negociações comerciais, e quando um maior número de produtos e temas são cobertos, potencializando os ganhos de acesso a mercados nacionais e globais (ANDERSON; NASH, 2006, p. 132).

Há de se destacar também um possível efeito lógico similar à teoria dos jogos no que concerne a ação protecionista ou liberalizante de forma unilateral. Caso um país que não seja competitivo imponha barreiras tarifárias de forma isolada, pode beneficiar o país que o pratica, mas se todos os demais países efetuarem a mesma política, o bem estar geral deteriora-se. O contrário pode ocorrer com a liberalização, já que, caso um país não competitivo realize uma abertura comercial ampla e rápida, pode vir a prejudicar sua indústria no curto prazo. Contudo, o benefício para o bem estar geral com a liberalização multilateral tende a ser muito maior do que a prática protecionista disseminada de forma ampla, assim como tende a favorecer o crescimento mundial, com o aumento da eficiência econômica e produtividade. A retaliação do protecionismo comercial, assim como o desvio de comércio, são efeitos também indesejáveis resultantes do protecionismo, os quais também são objetos das negociações multilaterais.

O Brasil é um defensor histórico do multilateralismo, âmbito no qual obteve uma influência maior do que a sua modesta participação no comércio internacional (ABREU, 
2015; ALMEIDA, 2013a), a exemplo da participação ativa nas negociações no âmbito do GATT. Até a Rodada do Uruguai, a posição brasileira nas negociações comerciais era de bloqueador (footdragger) da inclusão dos considerados novos temas em âmbito multilateral, tais como investimentos, propriedade intelectual e serviços (ABREU, 2007). No início da década de 1990, essa posição de footdragger viria a ser combinada com a posição de demandeur da abertura comercial de produtos agrícolas por parte dos países desenvolvidos (ABREU, 2007, p. 4). Essa combinação de posições por parte do Brasil seria relativamente constante também no século XXI, em uma espécie de parceira com a Índia.

A falta de avanços da Rodada Doha incentivou e ainda impulsiona os países a buscarem alternativas via acordos em outros níveis, notadamente pela via bilateral e preferencial. Exemplo disso são os avanços na negociação entre Estados Unidos e União Europeia para a formação de um acordo macro de livre comércio, o que geraria grande impacto nas relações econômicas internacionais, em termos de regras para compras governamentais, e regulação do comércio internacional ${ }^{59}$.

Figura 15 - Evolução dos acordos regionais de comércio notificados pela OMC

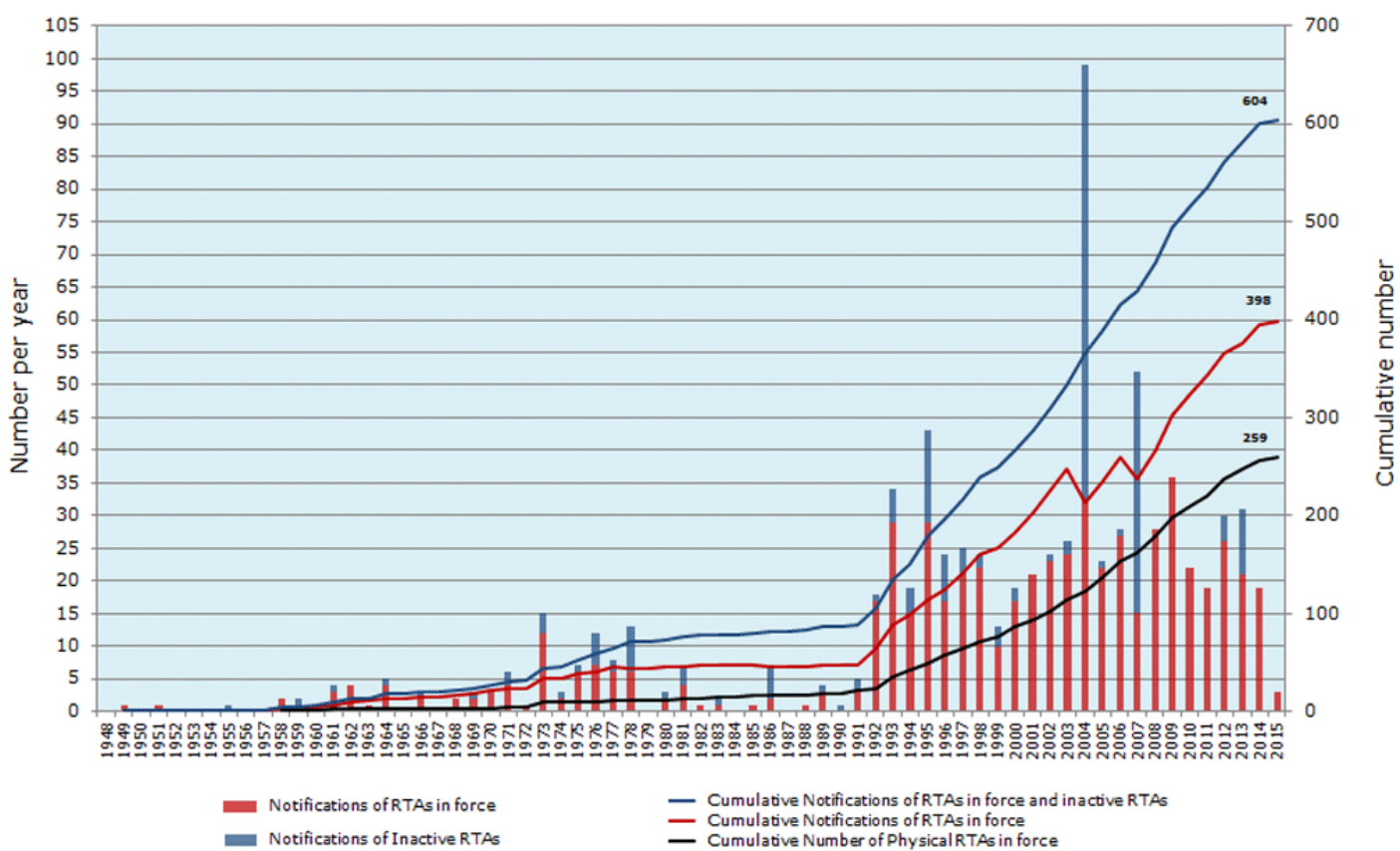

Fonte: WTO. Facts and Figures. <https://www.wto.org/english/tratop_e/region_e/regfac_e.htm>. Acesso em 23 mar. 2015. Nota: notificações de ARCs: bens, serviços e adesões a um ARC são contados separadamente. ARCS "físicos": bens, serviços e adesões a um ARC são contados conjuntamente.

\footnotetext{
${ }^{59}$ Cabe destacar que termos negociados em acordos de comércio pelos EUA tendem a se torna padrões para acordos futuros.
} 
A figura acima da OMC mostra a evolução do número de acordos regionais de comércio por ano de entrada em vigor, incluindo os acordos inativos. De 1948 a 1994, foram notificados 124 acordos regionais relacionados ao comércio de bens no Gatt. E acordo com o site a OMC, desde a criação da instituição em 1995, "mais de 400 acordos adicionais cobrindo comércio de bens e serviços têm sido notificados" (https://www.wto.org/english/tratop_e/region_e/ regfac_e.htm).

Mesmo com as negociações em andamento da Rodada Doha, tem-se registrado um aumento do número de acordos regionais de comércio, com um acúmulo de mais de 600 ARCs ativos e inativos notificados na OMC e mais de ARCs "físicos" (calculados sem dupla contagem dos ARCs em bens e serviços e sem a inclusão de adesões aos ARCs existentes). Muitos acordos tornaram-se redundantes na medida em que os acordos se expandiram com a inclusão de novos membros, o que justifica o grande número de ARCs inativos em 2004. O problema recorrente com essa proliferação de acordos é a produção de uma spaghetti bowl, uma sobreposição de regras. Isso poderia gerar distorções econômicas, aumentar os custos de transação para firmas que operam em vários ARCs, além de criar um "risco de fragmentação do sistema multilateral do comércio em centenas de mini blocos" (ESTEVADEORDAL; BLYDE; SUOMINEN, 2013, p. 11).

A governança das cadeias globais de valor, "a evidência empírica da globalização" (Conf. OLIVEIRA, 2014), tem demandando uma nova harmonização de regras para investimentos produtivos associadas aos novos termas travados nas negociações no sistema multilateral da OMC. De acordo com Valls (2013), "os custos de transação impostos por sistemas regulatórios distintos oneram o processo de globalização, que seria a fonte de dinamismo do crescimento mundial" (PEREIRA, L., 2013, p. 2), o que demanda uma harmonização das políticas domésticas. O Pacote de Bali é um passo importante para redução desses custos, mas são grandes os desafios frente à proliferação de temas a serem negociados. Dentre esses temas estão os serviços, intimamente ligados às especializações de tarefas em processos de fragmentação e dispersão da produção internacional, o cumprimento de direitos de propriedade intelectual, e mecanismos de solução de controvérsia entre os setores público e privado (PEREIRA, L., 2013).

É justamente nessa demanda por regras mais claras e harmonização regulatória no contexto da "fragmentação e dispersão internacional da produção", que o tema das cadeias globais de valor vincula-se às negociações em curso dos mega acordos 
comerciais - Transatlantic Trade and Investment Partnership (TTIP) e Trans-Pacific Partnership (TPP). Estes acordos de escopo plurilateral os quais visam "desatar os nós" da spaghetti bowl, além de desenvolver regras comuns aos seus membros.

Baldwin (2014) relata que um dos impactos sistêmicos das negociações dos Mega acordos é o de que firmas baseadas em nações que estão fora das negociações, como é o caso do Brasil, terão que acatar as regras negociadas. Acatar essas regras negociadas nos mega acordos, as quais definirão o modus operanti dos novos padrões de comércio internacional, implica em alguma medida a restrição à autonomia das políticas nacionais de indústria e comércio, o que iria de encontro ao interesse dos governos dos países do BRICS (PEREIRA, L., 2013).

\section{b) As Negociações do TTIP e TPP e o Brasil}

Um dos pontos muito importantes quanto à adaptação do Brasil às dinâmicas da economia global pode estar relacionado à certa negligência quanto à análise de como as relações de outros países e blocos nos afetam. A elaboração de uma estratégia de inserção internacional de uma economia demanda, sobretudo, um ajustamento ao ambiente estratégico e contexto internacional que afetam as escolhas nacionais. Essa análise pode considerar aspectos mais abstratos e interpretativos como a "multipolaridade do sistema internacional" ou mesmo "valor das coalizões Sul-Sul", até aspectos de impactos mais diretos como a perda de mercado ou o desvio de comércio em virtude de aproximação política e econômica de parceiros com países terceiros.

As negociações em curso dos mega acordos TTIP (Parceria Transatlântica) entre Estados Unidos e União Europeia, e da TPP (Parceria TransPacífico) entre países que circundam o oceano Pacífico são fatores que possivelmente ensejarão grandes mudanças no ambiente estratégico internacional, pois possuem grande potencial alterar, adicionar e reformular as "regras do jogo" no regime internacional de comércio, o que impactaria os países não participantes de forma considerável.

Para Thorstensen e Ferraz (2014), os mega acordos "abarcam parcela significativa do comércio mundial e podem trazer impactos importantes para o comércio exterior brasileiro" (p. 5). As negociações só agravariam uma situação já premente com a proliferação de acordos regionais de comércio que procuram lidar com as novas dinâmicas do comércio, dos quais o Brasil permanece relativamente isolado. O País, 
segundo os autores, vem sofrendo uma "perda relativa de acesso a diversos mercados internacionais em razão de preferências tarifárias, quotas agrícolas e redução de barreiras não tarifárias (BNT) concedidas por parceiros comerciais a outros países" (THORSTENSEN; FERRAZ, 2014).

Se concluídos, os Mega Acordos formarão uma espécie de regime internacional comercial paralelo a relativamente estagnada OMC (em termos de liberalização multilateral, pois atualmente o órgão mais bem sucedido da instituição é o seu Sistema de Solução de Controvérsias), deslocando o fórum de produção de regras internacionais (WEF, 2014). Além disso, os mega acordos negociam temas além do regionalismo convencional, tratando de questões referentes à propriedade intelectual, serviços e padrões ambientais, de difícil consenso em nível multilateral na OMC.

Para Bhagwati (2013, p. 11), a falha em concluir a Rodada Doha e os danos ao multilateralismo teriam sido liderados pelos Estados Unidos (pelo suporte ao TPP) e União Europeia (pelo apoio ao TTIP ao lado dos EUA), frente a iniciativas preferenciais de comércio que causam discriminação contra Estados não membros dos acordos. Além disso, segundo o autor, o presidente Obama não estaria disposto a confrontar os lobbies empresarias dos EUA, os quais pressionavam por novas concessões das grandes economias emergentes, como o setor agrícola da Índia, e do setor manufatureiro do Brasil (BHAGWATI, 2013). Há também alegações de que a Índia tenha liderado a paralisação da Rodada de Doha ao exigir que o dossiê agrícola fosse negociado antes dos demais. Na visão indiana e de diversos países em desenvolvimento, tal atitude almejava corrigir um desequilíbrio resultante da barganha entre economias mais e menos avançadas, o que permitiu a conclusão da Rodada do Uruguai (BONOMO, 2014, p. 5). De acordo com Amorim, além da eliminação dos subsídios agrícolas para exportações, o G-20 demandava o enquadramento do tema do desenvolvimento nas negociações comerciais (AMORIM, 2010).

Do ponto de vista da política internacional, os mega-acordos foram ensejados em momento de declínio relativo da superpotência dos EUA (mesmo que limitado, embora seja superestimado por muitos autores) em relação aos emergentes, em especial, à China. No pós-Segunda Guerra, os EUA foram grandes responsáveis pela liberalização do comércio mundial, bem como na promoção de bens públicos globais que impulsionaram a globalização econômica (ZAKARIA, 2008). Os mega acordos ganharam um impulso adicional no Governo Obama, após o aumento da percepção de 
que poderiam ser um "estímulo econômico em época de restrições orçamentárias" (WEF, 2014).

Considerações geopolíticas e de defesa contra invasões de produtos chineses são também fatores motivadores por trás das negociações do TTIP. Há uma preocupação por parte dos EUA com a redução de empregos formais no setor industrial norteamericano, muito em decorrência da competição com produtos industriais chineses de baixo custo, muitas vezes considerada uma "competição predatória" (ALMEIDA, 2013c, p. 35). Conforme afirmam Berggruen e Gardels (2013, p.54): "um quarto do declínio agregado do emprego fabril nos Estados Unidos ao longo das últimas duas décadas deveu-se ao comércio com a China".

Em relação aos ganhos comerciais derivados da Parceria Transatlântica, há considerações importantes sobre uma limitada criação de comércio além do existente entre Estados Unidos e União Europeia. De fato, grande parte do comércio entre EUA e UE já está liberalizado, e o acordo deve ser voltado para a padronização de tarifas e harmonização regulatória (ALMEIDA, 2013c), o que, possivelmente aumentará o comércio, mas não partirá de um valor inicial baixo.

No entanto, há potenciais efeitos danosos ao Brasil em termos de desvio de comércio. Caso o TTIP seja concluído, poderá afetar negativamente as exportações brasileiras de manufaturados para os EUA, bem como as exportações brasileiras de produtos agrícolas para a UE (THORSTENSEN; FERRAZ, 2014; MAGNOLI, 2014, p. 41). Thorstensen e Ferraz (2014) realizaram um estudo via simulações de equilíbrio geral computável (EGC) para avaliar os potenciais impactos ao Brasil resultantes dos dois mega acordos em negociação. Os resultados alcançados pelos autores são os seguintes:

- No caso do TTIP: (1) "a eliminação apenas das tarifas resulta em redução de 0,6\% das exportações brasileiras para os EUA e UE, correspondendo a uma diminuição de US\$ 0,4 bilhão"; (2) "a eliminação completa das tarifas em conjunto com a eliminação de $50 \%$ das BNTs resulta em queda mais significativa de $5 \%$ das exportações brasileiras para esses parceiros, correspondente a US\$ 3,8 bilhões" (p. $8)$.

- No caso do TPP: (1) "a eliminação completa das tarifas resulta em uma queda de $0,4 \%$ do total de exportações brasileiras, enquanto as importações sofrem uma queda de 0,4\%". (2) "a eliminação, também, de 50\% das BNTs resulta em uma 
queda mais acentuada das exportações, correspondente a 2,7\%, bem como em uma queda de 2,6\% das importações" (p. 12).

O comércio entre União Europeia e Estados Unidos é altamente concentrado em bens manufaturados, possivelmente tendo o comércio "intraindústria" como fonte. De acordo com dados da Comissão Europeia referente ao ano de 2013 (último ano disponível), a composição de bens manufaturados na pauta de exportações da UE para os EUA era de $84,4 \%$, e de importações $78,2 \%{ }^{60}$. De fato, as exportações de bens primários dos EUA para a UE possuem importância relativa maior do que o fluxo da UE para os EUA, embora nesse fluxo o valor seja maior. Em 2013, o valor das importações de bens primários da UE para os EUA somaram US\$ 37,7 bilhões e o valor de exportações também de bens primários somaram US\$ 38, 3 bilhões (EUROPEAN COMISSION data, 2014).

Quanto ao comércio entre Brasil e União Europeia, a pauta das exportações brasileiras para a UE em 2014 era composta por 51,8 \% de bens básico-agrícolas, 47,5\% de bens industrializados, dos quais $34 \%$ por bens manufaturados. Embora a porcentagem do componente da pauta exportações brasileiras para UE seja consideravelmente menor do que o mesmo item em relação aos EUA (em 2014, 34\% para os EUA a 50\% para a UE), o seu valor é maior: US\$ 14,1bilhões para a UE, e US\$13,6 bilhões para os Estados Unidos. Esse dado é plausível ao se considerar a economia agregada dos países da União Europeia, o que a traduz como "a maior economia do mundo, o maior exportador e importador, [e] a principal fonte e o principal destinatário de investimento estrangeiro" (COMISSÃO EUROPEIA, 2014) ${ }^{61}$.

Embora haja forças e grupos de certa forma resistentes ao acordo macro do TTIP - como o de agricultores norte-americanos -, caso seja firmado, o comércio de bens industriais dos EUA para a UE, bem como o comércio de bens agrícolas da UE para os EUA, serão regulatoriamente facilitados. Isso afetaria negativamente em curto prazo os exportadores brasileiros já que de acordo com dados da SECEX/MDIC, em 2014, mais $70 \%$ das exportações brasileiras para os EUA eram de bens industrializados (totalizando mais de US\$19 bilhões), destes, 50\% de manufaturados e $20 \%$ de semimanufaturados.

\footnotetext{
${ }^{60}$ EUROPEAN COMISSION SITE. European Union, Trade in goods with USA. Statistics. DirectorateGeneral for Trade, 17 ago. 2014. Disponível em: <http://trade.ec.europa.eu/doclib/docs/2006/september/tradoc_113465.pdf>. Acesso em: 15 jan. 2015.

${ }^{61}$ COMISSÃO EUROPEIA. Compreender as políticas da União Europeia: Comércio. União Europeia. Luxemburgo: Serviço das Publicações da União Europeia, 2014. Disponível em: <http://europa.eu/pol/pdf/flipbook/pt/trade_pt.pdf>. Acesso em 07 jan. 2015.
} 
O valor de exportações brasileiras de bens industrializados para os Estados Unidos vem apresentando melhora desde a drástica queda após a crise de 2008, ano em que alcançou o seu pico histórico de US\$ 21 bilhões: 2009: US\$ 11,4 bi; 2010: US\$ 13,1 bi; 2011: US\$16,9 bi; 2012: US\$ 18,5 bi; uma queda em 2013: US\$ 17,7; e retomada de US\$ 19 bi em 2014 (SECEX, 2015). Além da concorrência acirrada, o Brasil também provavelmente lidaria com o maior rigor de barreiras técnicas, tais como maiores exigências quanto a padrões estabelecidos no TTIP.

No tocante à Trans-Pacific Partnership, esta entrou em vigor em 2006, oriunda do Acordo de Parceria Estratégica Econômica Trans Pacífica (Trans-Pacific Strategic Economic Partnerchip Agreement) entre apenas quatro países conhecidos resumidamente por "P4", oriundos de três continentes: Brunei, Chile, Nova Zelândia e Cingapura. Ao longo do tempo, várias nações interessaram-se no intercâmbio intercontinental de mercadorias e investimentos, e o Acordo passou a ser visto como um grande exemplo da transição de poder à região da Ásia-Pacífico ao incorporar no processo de negociação os seguintes países: da América - Estados Unidos, Canadá, México e Peru; da Oceania - Austrália; e do Leste Asiático: Japão, Malásia e Vietnã. Em 2013, Coreia do Sul e Taiwan anunciaram oficialmente o interesse em aderir às negociações.

De acordo como o relatório do World Economic Forum "Mega-regional Trade Agreements: Game-Changers or Costly Distractions for the World Trading System?" $(2014)^{62}$ há também o interesse dos EUA em diminuir a centralidade da cadeia global de valor do Leste Asiático na China (WORLD ECONOMIC FORUM, 2014). Dentre os objetivos do TPP, estariam a atualização e a reconstrução de antigos acordos firmados na onda de regionalismos dos anos 1990/80; o tratamento de novos temas que possam ser precedentes a uma eventual multilateralização; e melhoria da competitividade econômica dos países membros (WEF, 2014). Apesar de excluir mais de 150 países das negociações, dentre os quais o Brasil, os Mega Acordos podem minar a centralidade da OMC na condução de acordos em temas não tarifários (WEF, 2014).

Segundo Nolte e Wehner (2013, p.5), os Estados Unidos veem a Parceria TransPacífico como um caminho alternativo para realizar os objetivos não atingidos pela APEC - Asia-Pacific Economic Cooperation firmados em 1994 em Bogor (Indonesia),

\footnotetext{
${ }^{62} \mathrm{O}$ relatório visa informar o debate político em torno dos grandes temas que moldam a agenda de comércio global.
} 
aproveitando o número de participantes deste acordo naquele ${ }^{63}$. O modelo de governança da APEC estabelecia o ano de 2010 para os compromissos dos países industrializados quanto à liberalização comercial e de investimentos, e o ano de 2020 para as economias não desenvolvidas, modelo este, em parte obsoleto quanto às forças econômicas do mundo globalizado (como descrito nas seções anteriores).

Assim como o TTIP, as negociações no TPP envolvem os novos temas do comércio como propriedade intelectual, padrões ambientais, compras governamentais, o que evidencia que caso sejam concluídos, poderão deslocar em alguma medida o lócus de produção de regras comerciais em nível global. Segundo o Fórum Econômico Mundial (2014), o TPP é responsável por 1/4 do comércio mundial e as trocas comerciais entre os seus países membros somaram U\$2 trilhões em 2012.

Além dos mega acordos per se, a emergência da Aliança do Pacífico somada à participação de seus Estados-membros nas negociações do TPP, apresenta uma possibilidade de grande ingresso ao mercado brasileiro de produtos provenientes da AP. Conforme relata o Embaixador Rubens Barbosa (2014), caso não haja um rigoroso controle e supervisão das regras de origem no mercado sul-americano, os países da Aliança do Pacífico podem vir a constituir uma plataforma de exportações para o Brasil. Essa implicação seria decorrente da participação de Chile, Peru, e México (a Colômbia está em trâmite de adesão às negociações) nas negociações do Trans-Pacific Partnership - TPP, o que, caso seja concluído com sucesso, facilitaria a importação de bens pelos países da AP que por sua vez poderiam reexportá-los sem passar por uma grande transformação manufatureira.

É importante destacar nas negociações dos mega acordos, a ausência países do BRICs - Brasil, Rússia, Índia e China, o que nutre argumentos de que estes países poderiam ser atores centrais na paralisação de negociações na OMC desde a conferência de Cancun em $2003^{64}$. Brasil e Índia eram líderes de um grupo de países que apostaram nas negociações multilaterais, e por possuírem vantagens comparativas no setor agrícola, envidaram esforços na organização pela liberalização do setor, o que os configura em posição de demandeur, ao mesmo tempo em que promovem uma

\footnotetext{
${ }^{63}$ China, Hong Kong, Indonésia, Papua Nova Guiné, Filipinas, Rússia, Taiwan e Tailândia fazem parte da APEC, mas não da Parceira Trans Pacífica (TPP). Há indícios de que a China deseja participar, embora ainda não tenha oficializado. In: APEC Site. Disponível em: <http://www.apec.org/About-Us/AboutAPEC/Member-Economies.aspx.>. Acesso em 20 fev. 2015.

${ }^{64}$ Esse isolamento dos BRICs também diz repeito às nogociações de um grande acordo secreto entre países desenvolvidos em serviços, o qual foi revelado pelo Wikileaks, chamado de "TISA" - Secret Trade in Services Agreement.
} 
resistência à liberalização do setor de serviços desejada pelos países desenvolvidos (ABREU, 2007). A China ingressou na OMC apenas em 2001, época em que o Estado apresentava altas taxas de crescimento e beneficiou-se enormemente dessa participação devido aos baixos custos da mão de obra e de produção no país (muitas delas com grande suspeita de dumping), e da desvalorizada taxa de câmbio com controle governamental, impulsionando enormemente as exportações do país. Já o anúncio de ingresso formal da Rússia à OMC foi realizado apenas em dezembro de 2011, por ocasião da $8^{\text {a }}$ Conferência Ministerial, tornando-se o $156^{\circ}$ Estado-membro, quando até então era a maior economia do mundo fora da organização (GODINHO; DOMINGUES, 2012).

Denota-se desse quadro, que uma das motivações das negociações do TTIP e TPP, foi justamente a falta de avanços nas negociações no eixo multilateral na OMC, a aposta brasileira desde 2003. Há de fato um isolamento brasileiro das negociações bilaterais, e o fato de o país não se encontrar nas grandes negociações dos mega acordos, bem como o atraso da conclusão das negociações do Mercosul com a União Europeia, poderão resultar no desvio de comércio dos fluxos comerciais do Brasil e minar as preferências comercais do país. Além disso, farão com que o Brasil acate padrões e normas que possam ser eventualmente multilateralizadas, podendo resultar em prejuízos ao País no que tange às maiores exigências regulatórias e barreiras não tarifárias. Diante disso, o ambiente estratégico internacional para a inserção externa do Brasil torna-se mais complexo e mais abstruso para o País em decorrência de escolhas de política externa brasileira, o que aumentaria os constrangimentos de seguir nesse percurso de ação, mais uma vez reforçando o path dependence. O Brasil teria o desafio da transição de rule-maker para rule-taker no comércio internacional, ou seja, de produtor de regras para tomador de regras.

\subsection{A Estrutura de Proteção Tarifária do Brasil}

Uma economia com as características como a do Brasil demanda certa proteção. O custo-país elevado, a infraestrutura deficiente, a burocracia, a alta carga tributária, a valorização do câmbio real, e o custo do capital resultam em perda de competitividade da indústria de transformação brasileira (FIESP, 2013; 2014). Entretanto, como relatado no primeiro capítulo desta dissertação, na era das cadeias de valor, o protecionismo 
tarifário quanto a bens de capital e bens intermediários - associados ao processo produtivo - tende a ser um custo autoimposto para as exportações de bens de alto valor agregado do país. O século XXI apresenta condições muito distintas para o desenvolvimento daquelas apresentadas por Chang (2002) para os séculos XIX e XX. Atualmente, além de serem maiores os custos da proteção tarifária e não tarifária, as restrições institucionais em âmbito multilateral impedem em muitos casos a utilização de intervencionismo que cause grandes distorções em outros países.

Empregado em excesso e de forma constante, o protecionismo comercial pode afetar negativamente o bem estar econômico e social. De acordo com o economista Jagdish Bhagwati (1993), há um risco corriqueiro decorrente da prática protecionista de que possa favorecer "interesses especiais" em detrimento de "interesses nacionais". Isso pode ocorrer quando os setores protegidos tendem a serem os mesmos durante vários anos, sem que ocorra uma revisão das tarifas. O problema adicional de favorecer determinados setores em detrimento de outros é o fomento de custos de lobbying ou prática de rent seeking, que busca direcionar atividades em prol do lucro por meios não produtivos, como a aliança indevida com a burocracia estatal e, portanto, não criando valor produtivo para o restante da sociedade (BHAGWATI, 1993).

As três tabelas a seguir mostram as tarifas ponderadas aplicadas a importações de bens de capital, de bens intermediários e de bens manufaturados em geral, adotadas pelo Brasil, pelos demais países emergentes, pelos países latino-americanos, além da média mundial referente ao período compreendido entre 2004 e 2013. Os dados não estão disponíveis em sua integridade na plataforma WITS do Banco Mundial para alguns países e anos, o que impede uma análise mais aprofundada. Todavia, os dados disponíveis ajudam na obtenção de inferências comparativas importantes quanto à magnitude das tarifas, e tendência ao longo do tempo.

Países tipicamente adotam tarifas nominais distintas ao longo de uma cadeia de produção. Conforme Anderson e Nash (2006, p. 125), estruturas tarifárias nacionais comumente apresentam a forma de escalada: quanto mais avançado um produto estiver em uma cadeia de processamento, maior será a tarifa aplicada. Considera-se aqui a pela plataforma de dados WITS seguindo a nomenclatura HS 1988/92, e a classificação de grupos de produtos seguindo dois dos "estágios de processamento": 905 produtos considerados bens de capital - bens utilizados para a produção de outros bens, como 
máquinas e equipamentos (seis dígitos); e 2049 produtos considerados bens intermediários - bens consumidos na produção de outros bens ${ }^{65}$.

Dentre todos os 71 países para os quais há dados disponíveis referentes ao ano de 2012, o Brasil ocupou a quinta posição de maior tarifa ponderada aplicada sobre a importação de bens de capital (9,6\%), atrás apenas de Camarões (12,8\%), Gâmbia $(12,8 \%)$, Aruba (13,4\%), e Bermudas (24,3\%). O País ficou à frente de países de renda baixa e de reduzido dinamismo econômico, como Etiópia (9,34\%), Sudão (9,0\% em 2011), Samoa (8,2\%), Senegal (7,8\%), Mali (7,78\% em 2011), Níger (7,73\%), Togo (7,57\%), Costa do Marfim (7,55\%), e Tanzânia (6,56\%). A tabela a seguir mostra a tarifa ponderada aplicada sobre bens de capital pelo Brasil e outros 18 países emergentes.

Tabela 7 - Tarifa ponderada para importações de bens de capital - Brasil e emergentes

\begin{tabular}{cccccccccccc}
\hline Países & $\mathbf{2 0 0 4}$ & $\mathbf{2 0 0 5}$ & $\mathbf{2 0 0 6}$ & $\mathbf{2 0 0 7}$ & $\mathbf{2 0 0 8}$ & $\mathbf{2 0 0 9}$ & $\mathbf{2 0 1 0}$ & $\mathbf{2 0 1 1}$ & $\mathbf{2 0 1 2}$ & $\mathbf{2 0 1 3}$ \\
\hline África do Sul & 2,2 & 2,3 & 2,3 & 2,4 & 2,4 & 2,4 & 2,2 & 2,1 & 2,0 & 1,9 \\
\hline Arábia Saudita & 5,8 & 4,7 & 4,7 & 3,8 & 3,2 & 3,3 & - & - & 3,6 & 3,6 \\
\hline Argentina & 5,5 & 5,0 & 5,4 & 5,8 & 5,5 & 5,6 & 5,9 & 6,0 & 6,4 & 8,1 \\
\hline Brasil & $\mathbf{1 0 , 8}$ & $\mathbf{9 , 9}$ & $\mathbf{9 , 1}$ & $\mathbf{9 , 5}$ & $\mathbf{9 , 4}$ & $\mathbf{9 , 3}$ & $\mathbf{9 , 5}$ & $\mathbf{9 , 7}$ & $\mathbf{9 , 6}$ & - \\
\hline Chile & 4,9 & 4,6 & 2,6 & 2,9 & 1,8 & 1,6 & 1,9 & 1,9 & 1,6 & - \\
\hline China & 4,2 & 3,9 & 3,1 & 4,6 & 4,3 & 3,7 & 4,4 & 6,5 & - & - \\
\hline Colômbia & 7,1 & 7,1 & 7,1 & 6,7 & 6,8 & 6,2 & 6,8 & 4,2 & 2,5 & 2,3 \\
\hline Coreia do Sul & 3,4 & - & 3,3 & 3,0 & - & 3,4 & 3,3 & - & - & - \\
\hline Egito & 7,7 & 6,6 & - & - & 6,5 & 6,4 & - & - & - & - \\
\hline Filipinas & 0,6 & 0,6 & 0,9 & 0,6 & 2,0 & 1,3 & 1,4 & - & - & - \\
\hline Índia & 21,7 & 9,6 & & 8,4 & 5,0 & 5,4 & - & - & - & - \\
\hline Indonésia & 4,5 & 4,6 & 3,6 & 2,6 & - & 1,9 & 2,4 & 2,6 & - & 2,2 \\
\hline Malásia & - & 1,7 & 1,1 & 1,0 & 1,0 & 0,9 & - & - & - & - \\
\hline México & 2,4 & 2,0 & 1,7 & - & 1,5 & 0,9 & 1,6 & - & - & - \\
\hline Nigéria & - & - & 5,5 & - & 5,2 & 6,0 & 7,7 & - & - & - \\
\hline Rússia & - & 7,5 & - & 4,5 & 4,2 & 4,7 & 3,4 & 5,6 & 5,3 & 4,0 \\
\hline Tailândia & - & 4,8 & 4,5 & 4,4 & 4,8 & 4,6 & - & - & - & - \\
\hline Turquia & - & 0,6 & 0,5 & 0,5 & 0,5 & 0,4 & 0,5 & 0,4 & - & 0,3 \\
\hline Vietnã & 6,4 & 6,8 & 6,2 & 5,5 & 4,2 & - & 3,3 & - & - & - \\
\hline América Latina e & $\mathbf{4 , 6}$ & $\mathbf{4 , 3}$ & $\mathbf{4 , 1}$ & $\mathbf{6 , 6}$ & $\mathbf{4 , 2}$ & $\mathbf{3 , 8}$ & $\mathbf{4 , 3}$ & $\mathbf{6 , 4}$ & $\mathbf{6 , 5}$ & $\mathbf{5 , 2}$ \\
\hline Caribe & $\mathbf{4 , 9}$ & $\mathbf{4 , 4}$ & $\mathbf{3 , 9}$ & $\mathbf{3 , 9}$ & $\mathbf{4 , 0}$ & $\mathbf{3 , 2}$ & $\mathbf{3 , 1}$ & $\mathbf{3 , 5}$ & $\mathbf{3 , 1}$ & $\mathbf{2 , 9}$ \\
\hline Mundo & $\mathbf{4 , n}$ &
\end{tabular}

Fonte: elaboração própria com base nos dado WITS $^{66}$.

\footnotetext{
${ }^{65}$ A divisão da WITS para estágios de processamento (stages of processing - SoP) é a seguinte: matériasprimas - UNCTAD-SoP1; bens intermediários - UNCTAD-SoP2; bens de consumo - UNCTAD-SoP3; bens de capital - UNCTAD-SoP4 (WITS data, 2015).
} 
Nota-se pela tabela 7 que o Brasil adotou uma tarifa ponderada para importações de bens de capital constantemente alta comparada aos demais países. A tarifa adotada em $2012(9,6 \%)$ era apenas 0,8\% menor do que a aplicada em 2004 (10,8\%), além de ser muito superior à adotada em todo o período pelos países latino-americanos e à média mundial.

A Argentina elevou sua tarifa de 5,5\% em 2004 para 8,1\% em 2013. Países como Arábia Saudita, Chile, Colômbia, Índia, Indonésia, México, Rússia, e Vietnã reduziram consideravelmente a tarifa adotada ao longo do tempo, mesmo com períodos de elevação. Nos casos de Rússia e Índia, as reduções nas tarifas merecem destaque. A Rússia adotava uma tarifa de 7,5\% em 2005, e reduziu para 4\% em 2013. Já a Índia aplicava uma alta tarifa de 21,7\% em 2004 - mais do que o dobro da adotada pelo Brasil (10,8\%), e em 2009 reduziu drasticamente para 5,4\% - bem abaixo da aplicada pelo Brasil (9,3\%).

Quanto à tarifa média ponderada para importação de bens intermediárias (tabela 8), de 72 países disponíveis na plataforma WITS em 2012, o Brasil adotava a 14 maior tarifa. Similarmente à aplicada para bens de capital, a tarifa ponderada adotada continuou alta e acima da adotada pelos países latino-americanos e pela média mundial. De 2004 a 2008, reduziu-se a tarifa de forma gradual - mesmo que de forma muito menos intensiva que os demais países da tabela abaixo -, de 6,9\% a 5,6\%. Entretanto, com a crise de 2008/2009 a tarifa elevou-se para 6,4\% em 2009, com mínima redução de $0,1 \%$ para $2010(6,8 \%)$ e 2011/2012 (6,7\%).

Destacam-se aqui as reduções tarifárias de África do Sul (2004 - 2013: de 4\% a 1,8\%), Arábia Saudita (2004 - 2013: de 6,7\% a 3,6\%), China (2004 - 2011: 7,5\% a 4,3\%), Colômbia (2004 - 2013: de 7,9\% a 2,6\%), Indonésia (2004 - 2013: de 4,5\% a 2,9\%), Malásia (2005 - 2009: de 9\% a 6\%), Rússia (2005 - 2013: de 7,8\% a 5,6\%) e Vietnã (2004 - 2010: 10,7\% a 3,5\%). Sobre a Índia, há uma carência de dados mas é possível notar que mesmo adotando a maior das tarifas dentre os países em análise, o país realizou uma grande redução da tarifa de 30,6\% em 2004 para 12,2\% em 2009.

\footnotetext{
${ }^{66} \mathrm{Na}$ definição da plataforma WITS: estimativa em termos percentuais da média ponderada da tarifa aplicada (\%) pelo valor importado de cada produto, para toda a pauta de importações. Classificação de produtos: Harmonized System 1988/92, HS 1996, HS 2002, HS 2007, HS 2012.
} 
Tabela 8 - Tarifa ponderada para importações de bens intermediários - Brasil e emergentes

\begin{tabular}{|c|c|c|c|c|c|c|c|c|c|c|}
\hline Países & 2004 & 2005 & 2006 & 2007 & 2008 & 2009 & 2010 & 2011 & 2012 & 2013 \\
\hline África do Sul & 4,0 & 3,7 & 3,4 & 3,0 & 2,7 & 2,8 & 2,2 & 2,2 & 2,1 & 1,8 \\
\hline Arábia Saudita & 6,7 & 4,0 & 4,2 & 4,1 & 3,6 & 3,4 & - & - & 3,6 & 3,6 \\
\hline Argentina & 5,5 & 4,6 & 4,4 & 4,7 & 4,7 & 5,1 & 5,1 & 5,1 & 5,3 & 5,4 \\
\hline Brasil & 6,9 & 6,2 & 6,0 & 5,9 & 5,6 & 6,4 & 6,8 & 6,7 & 6,7 & - \\
\hline Chile & 3,4 & 3,5 & 1,5 & 1,9 & 1,6 & 1,3 & 1,3 & 1,3 & 1,2 & - \\
\hline China & 7,5 & 6,5 & 5,7 & 5,6 & 5,1 & 4,6 & 4,5 & 4,3 & - & - \\
\hline Colômbia & 7,9 & 7,9 & 6,8 & 6,2 & 6,4 & 6,1 & 6,5 & 3,9 & 2,5 & 2,6 \\
\hline Coreia do Sul & 5,2 & - & 4,9 & 4,1 & - & 4,6 & 4,5 & - & - & - \\
\hline Egito & 8,9 & 7,2 & - & - & 5,8 & 4,9 & - & - & - & - \\
\hline Filipinas & 3,7 & 3,7 & 3,7 & 3,6 & 3,5 & 3,4 & 3,5 & - & - & - \\
\hline Índia & 30,6 & 18,1 & & 17,7 & 6,6 & 12,2 & - & - & - & - \\
\hline Indonésia & 4,5 & 4,8 & 4,5 & 3,8 & - & 2,0 & 3,0 & 3,1 & & 2,9 \\
\hline Malásia & - & 9,0 & 7,2 & 6,8 & 7,3 & 6,0 & - & - & - & - \\
\hline México & 2,6 & 2,2 & 1,7 & - & 1,2 & 1,0 & 6,0 & - & - & - \\
\hline Nigéria & - & - & 9,5 & - & 10,1 & 9,2 & 9,3 & - & - & - \\
\hline Rússia & - & 7,8 & - & 5,8 & 5,9 & 6,3 & 5,0 & 6,1 & 5,6 & 5,6 \\
\hline Tailândia & - & 4,2 & 4,2 & 2,9 & 2,8 & 3,0 & - & - & - & - \\
\hline Turquia & - & 2,0 & 2,1 & 2,5 & 2,8 & 2,7 & 2,2 & 2,1 & - & 1,9 \\
\hline Vietnã & 10,7 & 10,3 & 9,3 & 8,2 & 4,0 & - & 3,5 & - & - & - \\
\hline $\begin{array}{c}\text { América Latina e } \\
\text { Caribe }\end{array}$ & 4,6 & 4,4 & 4,3 & 5,5 & 4,2 & 3,8 & 5,5 & 5,1 & 5,1 & 4,2 \\
\hline Mundo & 6,2 & 5,2 & 4,4 & 4,3 & 4,0 & 3,9 & 3,2 & 3,3 & 3,1 & 3,1 \\
\hline
\end{tabular}

Fonte: elaboração própria com base nos dado WITS.

Quanto à tarifa média ponderada para bens manufaturados, de 73 países cuja tarifa estava disponível para o ano de 2012, o Brasil adotava a sétima maior tarifa, somente abaixo de Bermudas $(16,4)$, Camarões $(14,1)$, Sudão $(13,3)$, Gâmbia $(12,9)$, Etiópia $(10,8)$ e Aruba $(10,2)$. Destaca-se que a tarifa adotada pelo Brasil é maior do que países com renda menos elevada e de menor dinamismo econômico, como a média aplicada pela África Subsaariana $(7,8 \%)$.

Conforme a tabela 9, o Brasil adotou tarifas relativamente altas durante todo o período de 2004 a 2012. O País apresentou uma redução da tarifa de 2004 (10\%) para 2005 (9,4\%), e de 2005 para 2006 (9,0\%), menor valor apresentado no período. Entretanto, voltou a subir a tarifa antes mesmo da crise, quando elevou-se para 9,3\% em 2007, mesmo valor de 2008. Em 2009, a tarifa era de 9,8\%, em 2010, 10,3\%, e em 2011, 10,6\%, até ser reduzida levemente para 10,3\% em 2012, valor ainda acima do que apresentava em 2004. Assim como na tarifa ponderada para bens de capital, a Argentina 
também elevou sua tarifa, exibindo um aumento de 6,5\% em 2004 para 7,6\% em 2013, valor ainda bem abaixo do exposto pelo Brasil.

Dentre os BRICS, África do Sul (2004 -2013: de 6,5\% para 5,8\%) e Rússia (2005 - 2013: de 10,3\% para 5,8\%) reduziram a tarifa de primeiro ano disponível ao último do período. A Índia apresentou também uma grande redução da tarifa, apresentando o valor de $25,5 \%$ em 2004, e 7,5\% em 2009, embora esse valor tenha se elevado em relação a 2008. Com valores bem abaixo dos apresentados pelo Brasil, a China exibiu uma inconstância quanto à tendência, mas com variação pequena. $\mathrm{O}$ país registrou uma tarifa de 5,9\% em 2004, e de 6,2\% em 2011. Dentre todos os países analisados abaixo, somente a Nigéria adotou tarifas maiores do que as do Brasil em 2008, 2009 e 2010.

Tabela 9 - Tarifa ponderada para importações de bens manufaturados* - Brasil e emergentes

\begin{tabular}{|c|c|c|c|c|c|c|c|c|c|c|}
\hline País & 2004 & 2005 & 2006 & 2007 & 2008 & 2009 & 2010 & 2011 & 2012 & 2013 \\
\hline África do Sul & 6,5 & 6,8 & 6,6 & 6,5 & 5,4 & 6,0 & 6,3 & 6,2 & 6,0 & 5,8 \\
\hline Arábia Saudita & 6,3 & 4,4 & 4,5 & 4,2 & 4,0 & 3,8 & - & - & 4,1 & 4,1 \\
\hline Argentina & 6,5 & 5,7 & 6,1 & 6,6 & 6,3 & 6,7 & 6,8 & 6,7 & 7,2 & 7,6 \\
\hline Brasil & 10,0 & 9,4 & 9,0 & 9,3 & 9,3 & 9,8 & 10,3 & 10,6 & 10,3 & - \\
\hline Chile & 4,5 & 4,5 & 2,4 & 2,9 & 2,1 & 1,8 & 2,0 & 2,0 & 1,7 & - \\
\hline China & 5,9 & 5,3 & 4,5 & 6,1 & 5,9 & 5,8 & 6,0 & 6,2 & - & - \\
\hline Colômbia & 9,6 & 9,6 & 8,9 & 8,9 & 9,1 & 8,5 & 9,5 & 5,7 & 4,9 & 4,9 \\
\hline Coreia do Sul & 4,5 & - & 4,5 & 4,8 & - & 5,1 & 5,0 & - & - & - \\
\hline Egito & 12,1 & 10,7 & - & - & 9,7 & 8,8 & - & - & - & - \\
\hline Filipinas & 1,9 & 1,9 & 2,5 & 1,9 & 3,7 & 2,7 & 3,3 & - & - & - \\
\hline Índia & 25,5 & 12,8 & - & 11,9 & 5,9 & 7,8 & - & - & - & - \\
\hline Indonésia & 5,3 & 5,3 & 4,6 & 3,9 & - & 2,4 & 3,2 & 3,4 & - & 3,2 \\
\hline Malásia & - & 4,8 & 3,7 & 3,4 & 4,1 & 3,6 & & - & - & - \\
\hline México & 3,2 & 3,1 & 2,5 & - & 2,2 & 1,8 & 4,7 & - & - & - \\
\hline Nigéria & - & - & 7,6 & - & 9,8 & 9,9 & 11,0 & - & - & - \\
\hline Rússia & & 10,3 & & 6,8 & 8,6 & 7,5 & 4,8 & 6,8 & 6,3 & 5,8 \\
\hline Tailândia & - & 5,9 & 5,8 & 5,4 & 5,7 & 6,1 & - & - & - & - \\
\hline Turquia & - & 1,2 & 1,2 & 1,4 & 1,6 & 1,4 & 1,3 & 1,2 & - & 1,2 \\
\hline Vietnã & 12,2 & 11,9 & 10,8 & 9,2 & 5,9 & - & 5,5 & - & - & - \\
\hline $\begin{array}{c}\text { América Latina e } \\
\text { Caribe }\end{array}$ & 5,5 & 5,6 & 5,3 & 7,6 & 5,3 & 5,1 & 6,5 & 7,3 & 7,2 & 5,9 \\
\hline Mundo & 7,6 & 6,8 & 6,1 & 6,2 & 5,8 & 5,4 & 4,9 & 5,0 & 4,7 & 4,9 \\
\hline
\end{tabular}

Fonte: tabelamento próprio com base nos dado WITS.

*Nota: Produtos classificados de acordo com a segunda revisão SITC 5 a 8. 
Altos níveis de barreiras tarifárias podem impactar negativamente a competitividade das exportações de produtos de alto valor agregado, na medida em que encarecem o custo de produção. De acordo com Anderson e Nash (2006): "by discouraging the import of higher-value added products, these tariffs keep exporting countries dependent on production of these low-value added, primary products, which are also subject to high price volatility".

Além de incentivar uma demanda derivada, a troca de bens de produção - bens de capital, bens intermediários, matérias-primas, peças, dentre outros bens utilizados no processo produtivo - possui considerável potencial de difusão do progresso técnico e acesso à informação tecnológica atualizada. No contexto dos países em desenvolvimento, esse fator tornar-se mais importante, pois não são recebedores passivos de tecnologia, e os ajuda a superar custos administrativos e de logística decorrentes da distância regional (BAUMANN, 2013a).

As tarifas ponderadas adotadas pelo Brasil no período analisado (2004-2013) relevam-se demasiadamente altas para o contexto dos países emergentes seja para bens manufaturados, bens de capital ou bens intermediários. As evidências das políticas de inserção nos novos padrões de comércio internacional reforçam a necessidade de revisão do protecionismo por parte do governo brasileiro, assim como havia sido reavaliado no final dos anos 1980 no País, em virtude das dificuldades macroeconômicas e baixo crescimento verificado.

\subsection{A Evolução do Valor do Comércio Sobre o PIB de Países Emergentes Selecionados}

Um indicador importante para demonstrar o grau de abertura de uma economia, é a relação entre o valor transacionado com o resto do mundo e o valor da produção nacional - PIB. Esse indicador também é relevante no visto que a própria importância do comércio exterior de bens e serviços sobre o PIB em parte antecede à própria integração de uma economia no comércio internacional. Dentre as nove economias consideradas emergentes consideramos, em ordem alfabética: Argentina, Brasil, China, Índia, Indonésia, Coreia do Sul, México, Rússia e Turquia. 
Figura 16 - Comércio exterior (exportações + importações) de bens e serviços como \% do PIB - países emergentes selecionados

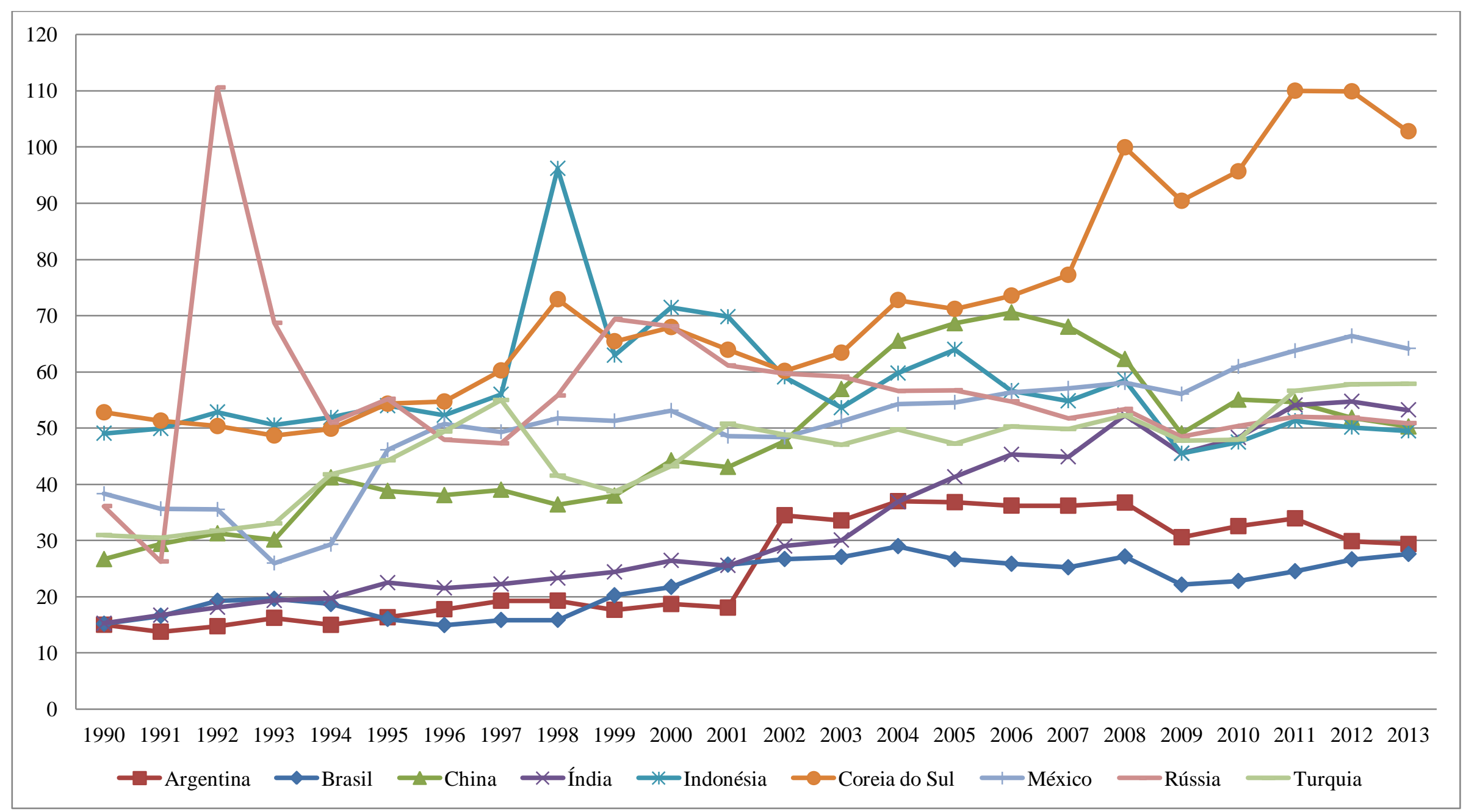

Fonte: elaboração própria a partir dos dados do Banco Mundial. 
Após a implosão da União Soviética em 1991, o acúmulo de bens industriais que ficaram sob o domínio de Moscou foi exportado a preços baixos, o que causou um surto de participação do comércio da Rússia sobre o PIB em 1992 para 110\%. Seguiu-se uma grande queda natural desse percentual em 1993 (68\%) e 1994 (50\%). Um novo crescimento do indicador seria verificado no fim da década de 1990 no governo de Boris Yeltsin - 69\% em 1999, e a partir daí, um leve e constante declínio nos anos 2000 nos governos Putin e Medvedev para algo em torno de 50\% em 2013. No século XXI, a economia russa ganhou maiores contornos de dependência da exportação de petróleo e gás, mantendo uma balança comercial constantemente superavitária (World Bank data, 2014). O país foi amplamente beneficiado pelo incrível aumento de seus termos de troca, de 64 em 1995 para 137 em 2012 (OECD data, 2015) ${ }^{67}$.

A Indonésia apresentou um alto coeficiente do comércio exterior de bens e serviços sobre o PIB em todo o período em análise, quase sempre acima de 50\% de 1992 a 2008. Um amplo aumento da relação comércio/PIB de quase 100\% foi experimentado em 1998 (96\%), ano em que apresentou a sua melhor relação em seus termos de troca $(120,2)$ desde 1993 até 2014, de acordo com dados da OCDE (2015). Assim como a Rússia, a Indonésia tem apresentado uma relação comércio/PIB em torno de 50\% nos últimos anos.

A Coreia do Sul é o país que apresenta o maior percentual dentre os países emergentes analisados, apresentando um crescimento quase que constante desde 1990, à frente dos demais desde 2002. O país elevou o seu percentual de exportações e importações justamente no período da crise de 2008, e apresentou um taxa de comércio sobre o PIB acima de 100\% desde 2011, quando atingiu o seu percentual máxico de $110 \%$. O país é o que possui a porcentagem de componente estrangeiro nas exportações do país dentre os países do G20, conforme análise mais adiante, o que aumenta o peso dos importados sobre a produção nacional (OECD TiVA data, 2013).

Ao contrário dos países exportadores de bens primários, a relação dos termos de troca da Coreia do Sul demonstrou contínua queda. Em 1991, essa relação era de 146,7; em 1998, era de 122,3; em 2003, 106,9; em 2007, 95,5; e em 2014, era de 90,9. O barateamento e redução dos custos de produção manufatureira estão por trás dessa relação dos termos de troca do país.

A Turquia apresentou crescimento do percentual do indicador sobre o valor do comércio sobre o PIB em torno de 30\% no início dos anos 1990, com um peso maior das

\footnotetext{
${ }^{67}$ OECD (2015), Terms of trade (indicator). doi: 10.1787/7722246c-en (Accessed on April 2015); Ano base: 2005.
} 
importações. Com as exceções dos anos 1994, 1998, 2001e 2002, desde 1990 a Turquia tem apresentado uma balança comercial deficitária, em especial desde 2010. Os termos de troca do país podem estar por trás desse fato, já que em 2005 o país apresentava a razão de 100, e em 2012, caiu para 86 (OECD data, 2014). O comércio sobre o PIB elevou-se para algo em torno de 57\% do PIB do país em 2013. O estreitamento de laços com os países europeus (embora a União Europeia não tenha ainda aprovado o ingresso do país em seu projeto de integração) foi fundamental para esse aumento. Cabe acrescentar que o país também não foi beneficiado pela relação dos termos de troca, já que em 2004 essa relação era de 100,3, e em 2014 era de 91,2.

O México aumento quase que continuamente o percentual de comércio sobre o PIB durante o período em análise. De 38\% em 1990, uma queda foi verificada em 1993 e 1994 para menos de 30\%, voltando a elevar o percentual para $46 \%$ em 1995, novamente 53\% em 2005. A integração no North American Free Trade Association (NAFTA), que entrou em vigor em $1^{\circ}$ de janeiro de 1994, foi fundamental nesse aumento. O país apresentando o seu maior percentual em 2012 de 66\%. Desde 2004 o país tem importado mais bens e serviços do que exportações, mas sem demonstrar um grande desequilíbrio da balança comercial. Em 2013, as exportações representavam 31,7\% do PIB mexicano, e as importações $32,4 \%$. Como o país é grande exportador de manufaturas, não foi tão beneficiado em seus termos de troca como países exportadores de commodities como Brasil, Chile, Austrália e Noruega. Tendo 2005 como ano base 100, os termos de troca do México subiram apenas para 105 em 2013 (OECD data, 2014).

Em relação à China, o enorme mercado interno ajuda a explicar a baixa participação do comércio sobre o PIB no início dos anos 1990, que não apresentava mais de 30\% em 1990 e 1991. Em 1995, a relação era de 38\%. Desde 1995, a China sempre apresentou superávits em sua balança comercial. O notável crescimento do percentual analisado ocorreu após o ingresso do país na Organização Mundial do Comércio - OMC em 2001, quando aumentou suas exportações de bens industriais via acessos a mercados, e aumento de importação de commodities devido ao aumento da população urbana e de seu poder de compra. O pico do percentual ocorreu em 2006, quando a corrente comercial alcançou 70,5\%\% do PIB, sendo as exportações de bens e serviços responsáveis por $39,1 \%$, e as importações por $31,4 \%$. Houve um crescimento vertiginoso das exportações chinesas a partir do século XXI. O país alcançou o incrível valor de um trilhão de dólares correntes em exportações em 2006. 
No ano de efeitos mais incisivos da crise internacional, em 2009 a relação do comércio caiu para 49\% após ter representado 68\% em 2007 e 62\% em 2008. Em 2013, o percentual era de 50\%, o que em si representa um enorme volume de corrente comercial, visto que o país apresentou crescimento a dois dígitos por muitos anos no século XXI, liderado pelas exportações. O país abriu-se gradualmente à economia global, e incorporou grandes volumes de insumos intermediários e importados em suas exportações, em especial na indústria manufatureira intensiva em mão de obra (JACOBS; ROSSEM, 2014, p. 54). A China alcançou dois trilhões de dólares em exportações em 2011, e em 2013, esse valor subiu para algo em torno de 2 trilhões e 440 bilhões de dólares correntes.

Cabe destacar novamente que essa expansão comercial e aumento extraordinário do crescimento da economia chinesa beneficiaram os países exportadores de commodities no século XXI, como minério de ferro e soja. Entretanto, diversos são os desafios para que a China continue no ritmo de crescimento da corrente comercial das ultimas décadas. O país passará por uma mudança macroeconômica para um maior nível de renda familiar e de consumo, bem como deverá lidar com o aumento da desigualdade e da poluição local. Isso provocará uma reavaliação do padrão de crescimento, visto que também aumentará encargos sociais decorridos do envelhecimento da população (SPENCE, 2011; NYE, 2011; VIOLA; LIMA, 2013).

Brasil, Argentina e Índia, que possuem uma parcela consideravelmente importante de commodities na pauta de exportações, mantiveram percentagem de comércio sobre o PIB nacional similar na década de 1990 em torno de 20\%. Contudo, no século XXI apresentaram caminhos distintos.

Assim como a China, a Índia integrou-se rapidamente na economia global a partir da década de 1990. O país abdicou de parte de uma política comercial obsessivamente próautossuficiência (BHAGWATI; PANAGARIYA, 2013), que justificava a baixa participação do comércio no início dos anos 1990. Em 1995, a corrente comercial de bens e serviços era de $22,4 \%$, sendo $10,6 \%$ de exportações, e de $11,8 \%$ de importações. Em 2000, o percentual de comércio sobre o PIB era de 26,4\%. A partir daí, haveria um grande aumento quase que contínuo dessa participação. Em 2003, a relação da corrente comercial/PIB alcançou 30\%; 41\% em 2005; 52\% em 2008; e 53\% em 2013. Desde 1994, as importações indianas de bens e serviços têm superado as exportações. Apesar da balança comercial deficitária, os economistas indianos, Bhagwati e Panagariya (2013), destacam que a abertura comercial e os investimentos indianos foram fundamentais para reduzir a pobreza do país nas duas últimas décadas. 
Após uma baixa participação do comércio sobre o PIB na primeira metade dos anos 1990, a Argentina aumentou essa relação para cima de 20\% apenas em 1996 (21,5\%). Com a crise de 2001e o abandono da taxa de câmbio fixa, o PIB argentino retraiu e o peso argentino foi subitamente desvalorizado. As exportações representavam 11,5\% do PIB em 2001, passaram a representar 28,3\% em 2002. Com isso, e com um aumento da participação dos importados (de 10,2 em 2001 a 13,3 em 2002), a relação da corrente comercial sobre o PIB saltou de 21,8\% em 2001 para 41,7\% em 2002. A Argentina, assim como o Brasil, foi beneficiada pela alta dos preços das commodities. Entre 2004 e 2008, a relação comércio/PIB se manteve em torno de $36 \%$. Com a crise, houve um declínio da participação das exportações do país. A balança comercial foi superavitária durante todo o período de 2001 a 2012, e a Argentina voltou a apresentar déficit comercial em 2013.

O Brasil somente alcançou a faixa de $20 \%$ da relação comércio/PIB em 1999, com as importações representando 10,8\% do PIB e as exportações 9,4\%. Em 1990, essa relação da corrente comercial era de $15,1 \%$. Em 2003, era de $27 \%$, com as exportações respondendo por 14,9\%, e as importações por 12\%. Em 2010, era de 22,7\%, com as exportações representado $10,8 \%$ e as importações $11,9 \%$. Em 2013, a relação voltou a subir para $27,5 \%$, com maior aumento das importações, sendo $12,5 \%$ a relação das exportações, e $15 \%$ a relação das importações.

Mesmo tendo elevado o valor transacionado com o resto do mundo em relação à década de 1990 - muito em razão do crescimento verificado no século XXI até a crise de 2008 - o Brasil elevou relativamente pouco a participação da corrente comercial em seu PIB em comparação com os demais países emergentes. Embora na primeira década do século XXI o Brasil tenha aumentado essa relação, Índia e Argentina elevaram essa proporção em maior medida, conforme a figura 16.

Mesmo com o aumento das importações nos últimos anos, o peso dos importados na economia brasileira é ainda muito em comparação com demais países do globo. Em 2012, por exemplo, para todos os países para os quais havia dados disponibilizados pelo Banco Mundial, o Brasil ocupou a última posição mundial da participação das importações sobre o PIB: 14 03\%. A Argentina ocupava a antepenúltima posição, com 14,06\%.

Outra forma de evidenciar essa baixa participação do comércio sobre o PIB no caso do Brasil, é o seu posicionamento de forma comparada aos demais emergentes no ano de 2013, conforme a figura 17. 
Figura 17 - Comércio como \% do PIB em 2013 de países emergentes selecionados

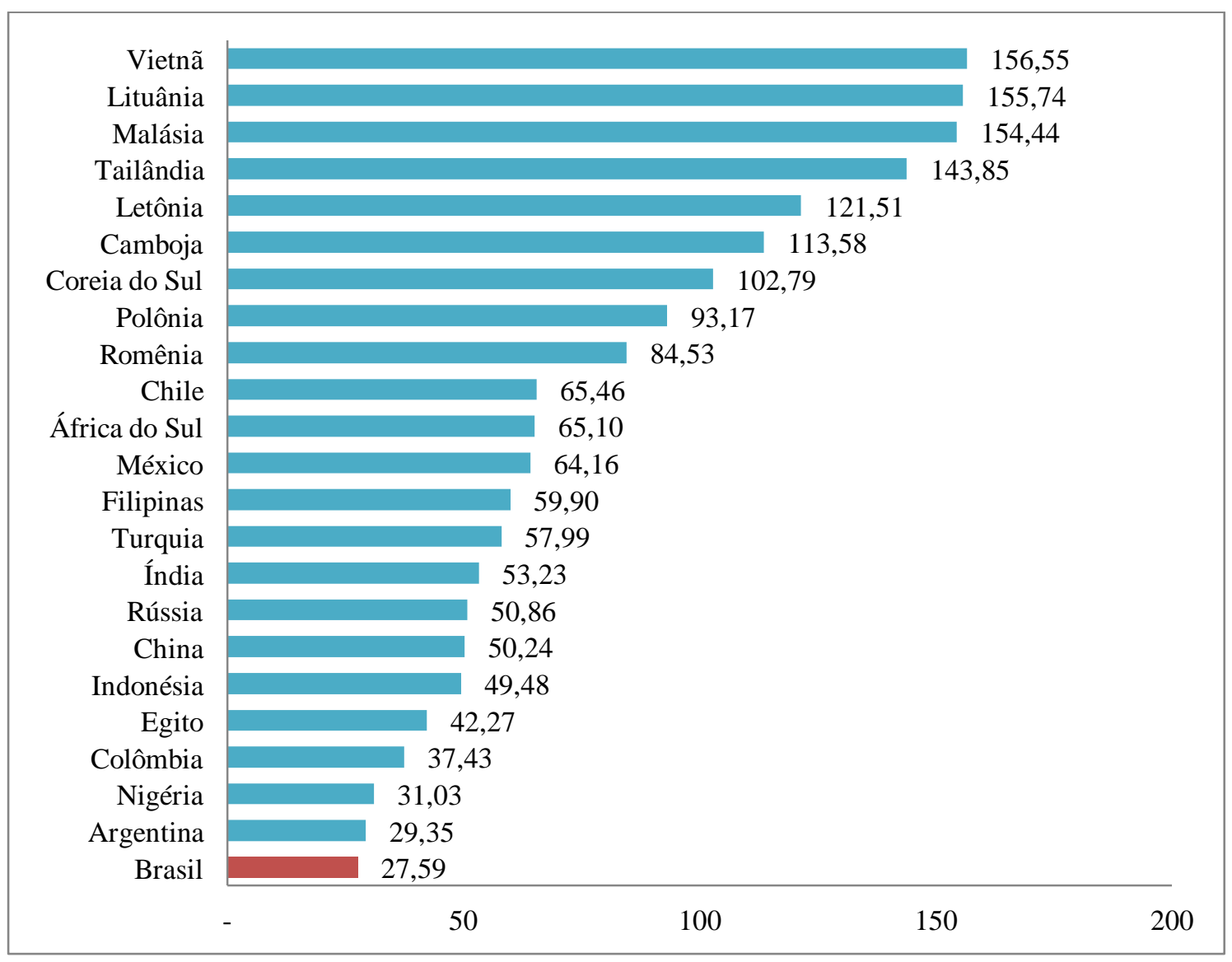

Fonte: elaboração própria, com base nos dados do World Bank 2013.

O Brasil é dentre os países emergentes no mundo e também dentre as vinte maiores economias do mundo o que possui a menor participação do comércio em relação ao PIB. No mundo em 2013, dentre todos os países para os quais o Banco Mundial disponibilizava os dados, apenas o Sudão - um país que convive com uma interminável guerra civil possuía uma participação do comércio sobre o PIB menor do que o Brasil.

Importante notar que o principal parceiro comercial regional, a Argentina, apresenta indicadores de baixa integração na economia global próximos aos do Brasil. Isso é pouco coerente com a lógica de fomento da integração econômica regional, visto que a ênfase nas exportações combinadas com as importações de bens de produção foi fundamental para que os países do Leste Asiático apresentassem altos níveis de integração de fato.

Apesar de ser a sexta economia do globo, o Brasil ocupou apenas a $23^{\mathrm{a}}$ posição dentre os maiores exportadores do mundo em US\$ FOB no ano de 2013, de acordo com a SECEX, e apenas representando 1,32\% das exportações mundiais. Boa parte dessa baixa participação reside no grande mercado interno, e na opção brasileira de proteção do 
mercado doméstico em boa parte do século XXI até 2014, via barreiras tarifárias e não tarifárias, contribuindo para a continuidade de uma baixa parcela de importações e exportações na economia brasileira comparativamente aos demais emergentes.

\subsection{O Lugar do Brasil nas CGV}

Como descreve Kaplinsky (2000), há dois questionamentos em torno da integração econômica internacional de países em via de desenvolvimento. A primeira indagação é sobre integrar-se ou não na globalização econômica. Como afirmou Martin Wolf em 2001 em artigo da Foreign Affairs, "a country that chooses international economic integration implicitly accepts constraints on its actions" (WOLF, 2001). Tais constrangimentos podem ser oriundos da aceitação de padrões internacionais mais rígidos do que aqueles encontrados domesticamente, ou mesmo restrições às políticas macroeconômicas internas. É natural que tais restrições possam ser percebidas, especialmente por países não desenvolvidos, como limitadores da autonomia, ou até mesmo da soberania nacional. Contudo, não integrar-se pode levar um país a um isolamento produtivo, comercial e financeiro, que limitará grandemente a concorrência, resultando em perda de eficiência econômica, com aumento de custos de oportunidade e de custos futuros ao bem-estar social. O caso da Coreia do Norte pode ser considerado o caso mais evidente de país que optou por fechar-se aos processos globalizantes, e vê a discrepância de desenvolvimento em perspectiva comparada à vizinha Coreia do Sul aumentar ao longo do tempo.

Se a integração crescente à economia global é uma opção mais viável e muito mais benéfica às economias nacionais do que a opção de não se integrar, torna-se plausível um segundo questionamento: os benefícios da inserção econômica internacional podem estar amplamente relacionados à posição ocupada pelo país na economia internacional, portanto, são assimétricos. Esse questionamento é comum em praticamente todas as teorias de economia política internacional. A integração da economia de um país nas Cadeias Globais de Valor é um grande exemplo factual da pertinência desse questionamento.

A variável problemática em torno da participação do Brasil nas cadeias globais de valor está relacionada ao lugar ocupado do País nas posições mais baixas e menos rentáveis, e, portanto, menos capaz de angariar grandes benefícios das CGV. Trata-se de uma baixa inserção, na qual o país é em maior parte fornecedor de matérias primas, ou de limitadas transações de bens de produção em processos produtivos internacionais. Trata-se 
assim de uma baixa integração nas Cadeias Globais de Valor, onde os benefícios são menores comparados a outras etapas, como aquelas voltadas à concepção do produto ou à produção/montagem final com serviços embutidos.

De acordo com a OCDE, há dois tipos de participação nas CGVs, de acordo com a porcentagem das exportações dos países. Curiosamente, os dois modelos se assemelham ao curso de um rio dentro de países, como em sua ligação à montante mais próxima à "fonte" (rio acima) e ligação à jusante, mais próxima da "foz" (rio abaixo). O primeiro indicador, refere-se aos upstream links, também chamado de backward participation, do ponto de vista de quem "está olhando para trás ao longo da cadeia de valor e mensurando o valor ou input estrangeiro adicionado nas exportações de um país" (OECD, 2013). O outro indicador, chamado de downstream links, ou forward participation, mede "o valor ou input doméstico adicionado de um país contido nas exportações de outros países, olhando-se para frente ao longo da cadeia de valor" (OECD, 2013). O gráfico abaixo mostra a participação de 40 países analisados pela iniciativa conjunta da OCDE com a OMC, em termos de valor acionado (Trade in Value-Added - TIVA).

Figura 18 - Participação nas CGV de 40 países em 2009

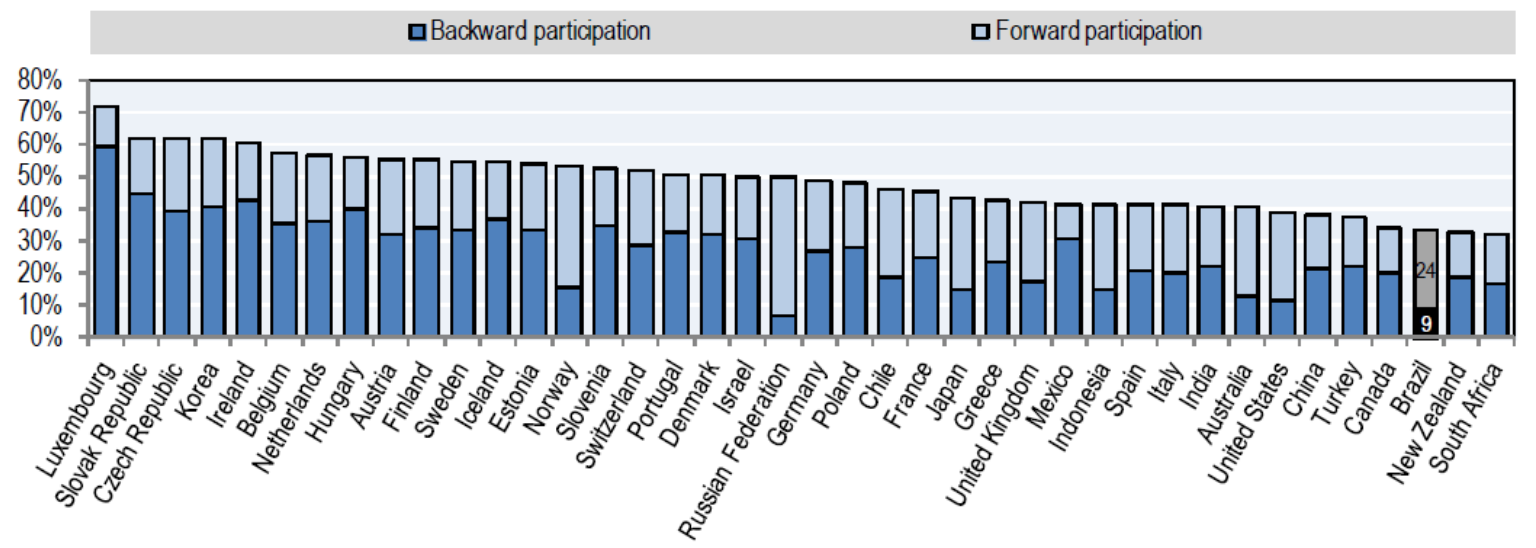

Fonte: OCDE, 2013. Disponível em: <http://www.oecd.org/sti/ind/GVCs\%20-\%20BRAZIL.pdf >. Acesso em: 20 mar. 2015.

Esses dois indicadores destacam o fluxo de bens intermediários ou componentes estrangeiros e nacionais embutidos nas exportações finais. De acordo com Miroudot e De Backer (2013), "a participação nas CGV é influenciada pelo tamanho da economia, estoque de recursos naturais, distância dos mercados globais, composição das exportações (final vs. intermediários), etc." (apud OCDE, 2013). Nota-se que países de reduzido tamanho geográfico e economias menores como Luxemburgo, Eslováquia, República Tcheca e 
Irlanda tendem a participar mais das CGV do que nações maiores como Estados Unidos, China e Canadá, diante da maior disponibilidade de fatores de produção nestes e relação àqueles.

Tendo como base o agregado dos dois modos de integração, o Brasil ocupa a antipenúltima participação nas CGV dentre os países em análise, à frente apenas da África Sul e de Nova Zelândia, países situados geograficamente no hemisfério Sul do mundo. O País participa muito mais como fornecedor de bens intermediários e outros inputs para a composição de bens finais de outros países do que em termos de componentes estrangeiros embutidos nas exportações nacionais. A geografia não é um fator favorável nesse sentido ao Brasil nessa participação, já que o país situa-se relativamente distante dos principais mercados globais, assim como Nova Zelândia e África do Sul.

A figura abaixo mostra uma perspectiva evolutiva do indicador de backward participation, ou seja, de valor estrangeiro adicionado nas exportações brutas, das 20 maiores economias do globo, em 2000 e 2009. Nota-se pelo gráfico sobre o valor estrangeiro adicionado nas exportações brutas que houve um aumento do componente estrangeiro nas exportações dos países considerados hubs em suas respectivas cadeias de valor regionais em 2009 (último ano disponível para dados equivalentes pela OCDE) e relação ao ano 2000: Estados Unidos, Japão e Alemanha, em menor medida, e, Coreia do Sul e China, com grande aumento (mais de 10\%, e mais de 20\%, respectivamente).

Dentre os emergentes, Índia e Turquia destacam-se pelo aumento dos componentes estrangeiros embutidos nas exportações finais em mais de 10\%, após terem realizado uma liberalização comercial na primeira década do século XXI. O Brasil junta-se aos demais emergentes os quais a economia é primariamente baseada em recursos naturais (portanto, baixo grau de transformação), como Rússia e Indonésia, reduzindo a porcentagem de componente estrangeiro de suas exportações finais. Dentre os países analisados no indicador, o Brasil fica somente à frente de Rússia e Arábia Saudita, países que possuem uma economia baseada na exploração e exportações de petróleo e gás, de participação marginal possível nas $\mathrm{CGV}$, já que não são processos de fácil "fatiamento" internacional. 
Figura 19 - Valor estrangeiro adicionado nas exportações brutas das 20 maiores economias do mundo

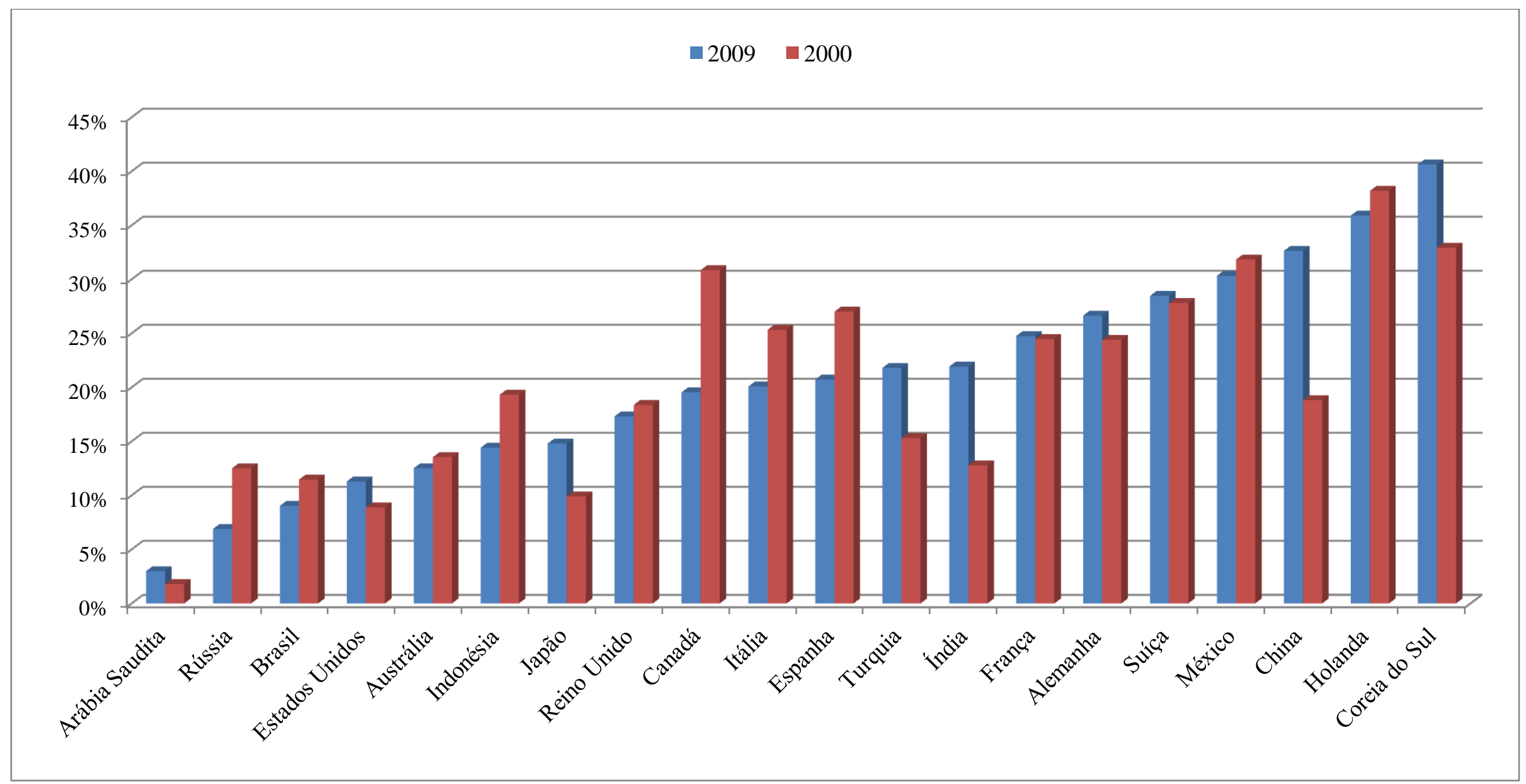

Fonte: Elaboração própria, com base nos dados OECD-WTO, Trade in Value Added database, Nov. 2014. 
Importante destacar que, como é apontado por Araújo Jr. (2013), a natureza da base técnica de cada indústria determina as possibilidades de fragmentação da produção, mudando o "perfil de integração vertical das firmas" (p. 43). Segundo o autor,

Elas são altas nas indústrias de montagem, como aeronáutica, automobilística, material eletrônico, vestuário e outras; são moderadas nos ramos onde o processo de produção é segmentado, como a indústria têxtil, que reúne as etapas de fiação, tecelagem e acabamento; e são muito limitadas, ou inexistentes, em indústrias de processo contínuo, como química e siderurgia, onde o perfil da empresa decorre da tecnologia escolhida e sua respectiva escala de produção. Assim, em cada país, a importância das cadeias globais de valor está diretamente associada à estrutura de sua economia (ARAÚJO Jr., 2013, p. 43).

Os setores com alto ou maior grau de transformação, como maquinaria, equipamentos elétricos e equipamento de transportes são aqueles que demonstram a maior participação relativa de componentes estrangeiros nas exportações do Brasil tendo como referência a produção doméstica do próprio setor. Os setores referentes à agricultura, mineração, químicos \& minerais, e metais básicos são aqueles que possuem maior participação no agregado dos dois indicadores, mas com amplo predomínio no valor adicionado nas exportações de outros países.

Figura 20 - Participação setorial do Brasil nas CGV em 2009

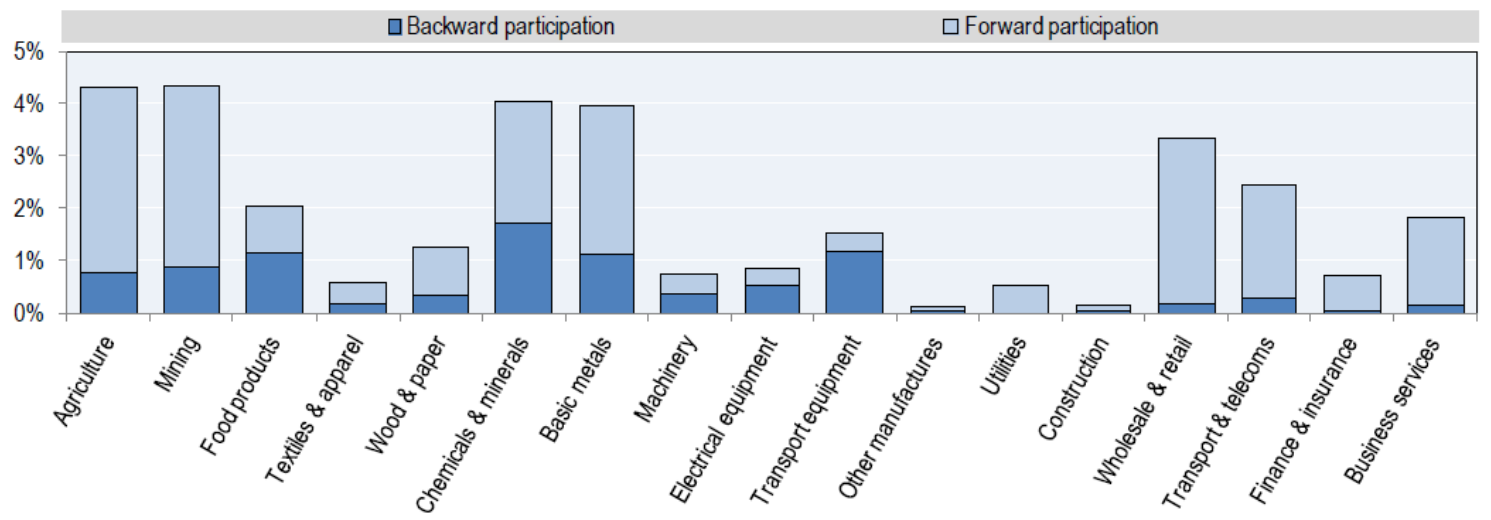

Fonte: OCDE, 2013.

O diversificado parque industrial brasileiro é uma grande fonte de bens intermediários não só para a economia nacional, como para a economia de outros países. Contudo, a maior parte dos bens intermediários do país está ligada à grande 
disponibilidade de recursos naturais, fonte de grande produção e exportações do setor primário, conforme a figura $22^{68}$.

A dimensão do mercado interno justifica em grande parte o alto valor doméstico adicionado na demanda final de diversos países. Na figura21 são mensurados apenas os bens manufaturados e os serviços de mercado, considerados pela OCDE como proeminentes nas CGV. Em 2009, apenas o Japão possuía uma maior parcela de valor doméstico adicionado na demanda final do que o Brasil, dentre todos o países analisados. O Brasil possuía apenas $13 \%$ de valor estrangeiro adicionado no quesito em análise. De acordo com a OCDE (2013), no Brasil o valor estrangeiro adicionado na demanda final por bens manufaturados é maior do que o adicionado para serviços de mercado, embora ainda seja considerado muito baixo.

Figura 21 - Valores domésticos e estrangeiros adicionados na demanda final de países selecionados em 2009

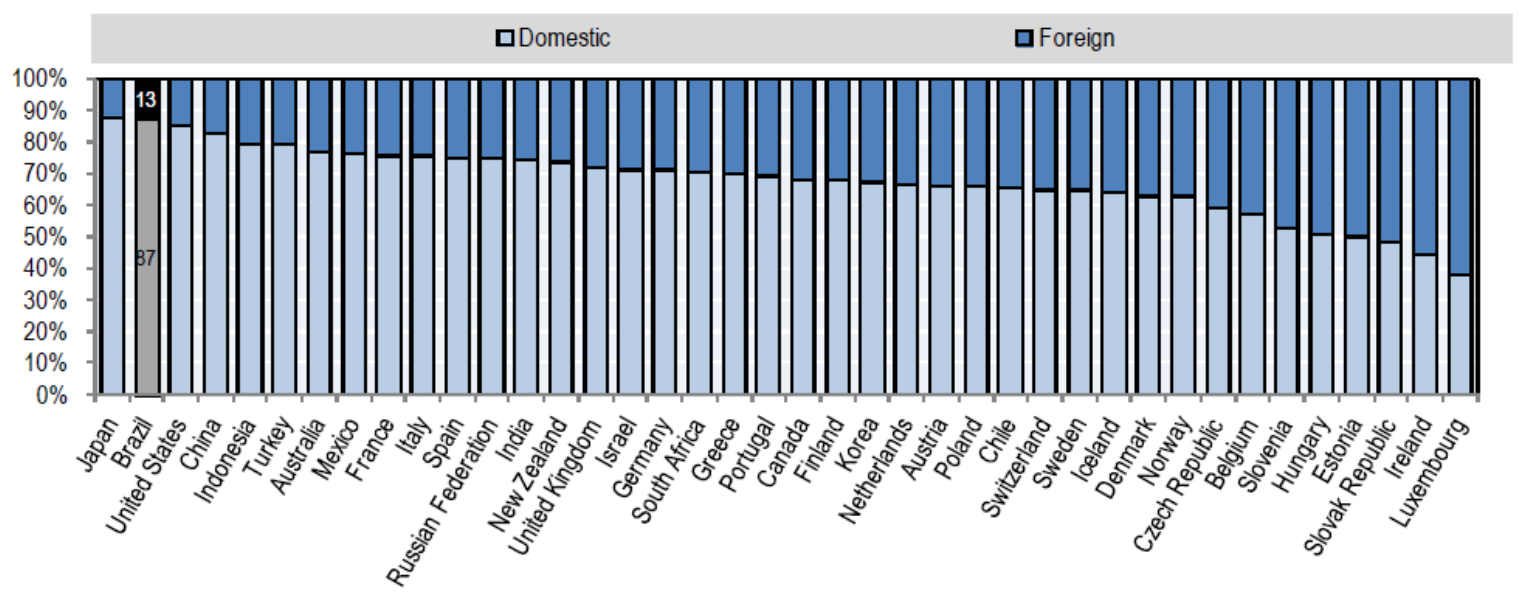

Fonte: OCDE, 2013

O fato de países mais desenvolvidos como Japão e Estados Unidos possuírem parcelas de valor doméstico adicionado similares às parcelas do Brasil pode ensejar argumentos equivocadamente positivos quanto ao baixo valor estrangeiro na demanda brasileira quanto a uma autossustentabilidade em nível de países centrais. Entretanto, assim como o indicador da parcela de corrente comercial sobre o PIB nacional, no qual, os EUA e Japão possuem também baixos percentuais próximos aos do Brasil, ressaltase que os dois países avançados atuam próximos da fronteira tecnológica, com alto

68 Conforme a OCDE/WTO (2013), "se expressa o indicador do nível industrial relativamente às exportações totais do país (em vez das exportações industriais) a fim de destacar a importância da indústria na composição das exportações totais de um país". 
valor doméstico na produção local em qualidade e conteúdo de conhecimento. Já o Brasil, conforme destaca Canuto (2014a; 2014b), não possui o nível de sofisticação tecnológica para respaldar o alto nível de composição doméstica tanto das exportações do país como da demanda doméstica final. Esse fato é uma demonstração dos custos de oportunidades associados às cadeias de produção nacionais. Para que um país possa competir na economia internacional fora dos novos padrões de comércio, seria necessário que seus produtores controlem uma tecnologia muito avançada, o que não é o caso do Brasil (CANUTO, 2014a).

Figura 22 - Parcela de exportações em termos de valor adicionado e exportações brutas de 40 países em 2009

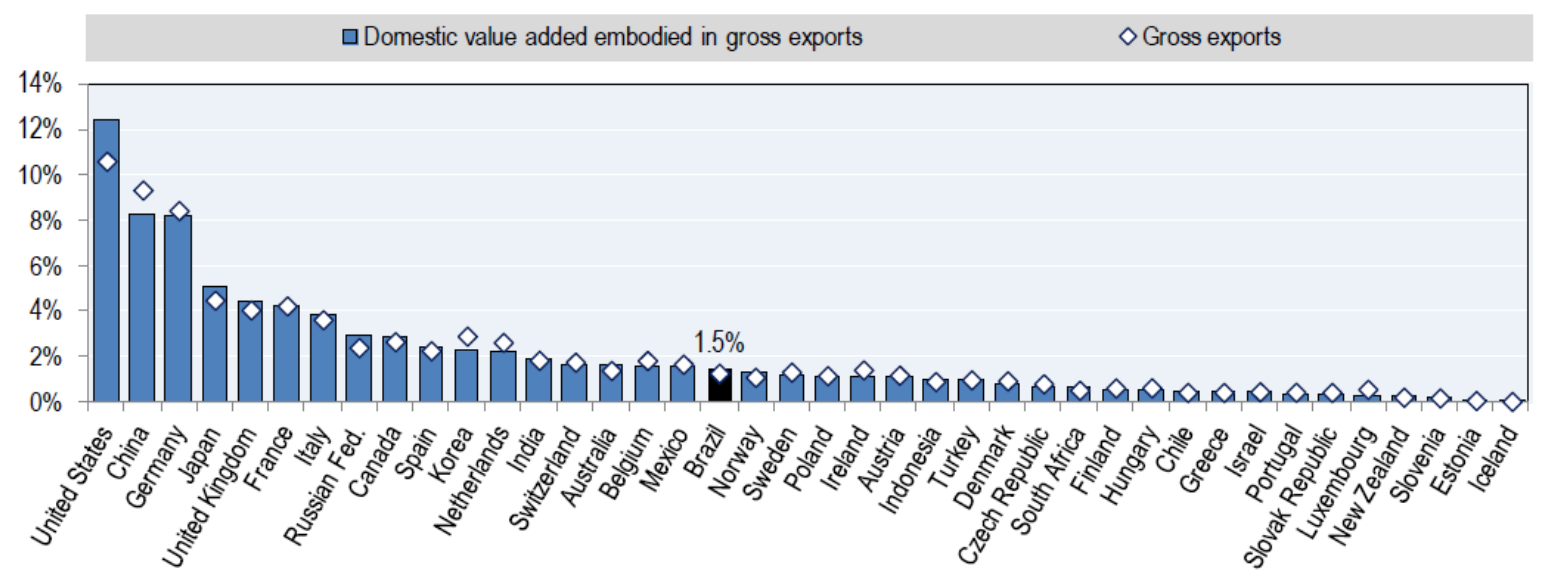

Fonte: OCDE, 2013.

Apesar de ser a sétima maior economia mundial, o Brasil apresenta baixa participação no comércio internacional relativa ao seu tamanho, tanto em temos de mensuração do comércio tradicional em exportações brutas, quanto em termos de valor adicionado, esta última considerada pela OCDE como "mais apropriada para indicar a competitividade de um país na economia global" (OCDE, 2013). As exportações em termos de valor adicionado são levemente superiores às exportações brutas do País (1,5\% a 1,3\%), diante da baixa participação estrangeira nas exportações do país e fornecimento de bens intermediários para o exterior (OCDE, 2013). 


\section{CONSIDERAÇÕES FINAIS}

Parafraseando Albert Sorel ${ }^{69}$, os países nos sistema internacional dividem-se entre "aqueles que imaginam o mundo de modo a adaptá-lo à sua política, e os que elaboram sua política de modo a adaptá-la às realidades do mundo". Em termos de integração na economia global, o Brasil aparenta ter se situado na primeira opção mesmo sem ter o poder de moldar as dinâmicas do mundo à sua própria vontade. Diante da interdependência global, há um mundo lá fora que existe independentemente da vontade do País, mas que o afeta consideravelmente.

Há um descompasso da política comercial brasileira com a ordem econômica internacional. O Brasil pode estar buscando objetivos irrealistas em prol da autossuficiência e substituição de importações, não adaptados à inserção no comércio internacional. Cabe destacar os exemplos de China e Índia em épocas passadas. Enquanto o Estado chinês abdicou de doutrinas marxistas para se inserir nos mercados globais no final da década de 1970, a Índia também reduziu consideravelmente o esforço por uma política comercial obsessivamente autônoma nos início dos anos 1990. O Brasil aparenta ter adotado políticas sem considerar realidades da economia global, muitas delas com base em princípios e doutrinas como a inserção soberana e resguardo da autonomia nacional, negligenciando assim a análise de resultados de longo prazo.

Fatores ideacionais ou aspectos ideológicos são particularmente importantes para a compreensão de opções de política. Esses fatores influem enormemente no processo de tomada de decisão na medida em que sistemas de crenças e de visão de mundo formam uma base para antecipar preferências a certos resultados. Em matéria econômica e comercial, mesmo que evidências empíricas ajudem na tomada de decisão na pretensão de prever em parte o futuro ou antecipar eventuais choques externos em situações de riscos e oportunidades aparentes, os Estados lidam frequentemente com situações de informação imperfeita. Por conta disso, há por muitas vezes um ambiente estratégico de múltiplas incertezas. A tradição de nacionalismo econômico de um país voltado à proteção heterodoxa do mercado interno possui custos maiores no contexto da globalização econômica produtiva e comercial no século XXI. Do ponto de vista ideacional/ideológico, o Brasil resguarda quase que incondicionalmente a soberania e

69 SOREL, Albert. L'Europe et La Révolution Française, pg. 474. apud. CARR, Edward Hallet. Vinte Anos de Crise. Brasília: Ed. Universidade de Brasília. p. 18 Disponível em <http://funag.gov.br/loja/download/40-Vinte_Anos_de_Crise_-_1919-1939.pdf>. Acesso em: 29 jan. 2015. 
autonomia nacional, não muito coerente com a integração econômica nos novos padrões de comércio internacional. O Brasil carece de uma visão estratégica de integração comercial e produtiva (AMARAL, 2013).

No plano regional, o Brasil optou pela promoção de uma integração no modelo "regionalismo pós-hegemônico" em contraposição ao "regionalismo aberto" dos anos 1990, no qual a temática econômica perdeu espaço na agenda de integração do subcontinente. Esse fato contribuiu para que o Mercosul e a América do Sul permanecessem à margem das grandes transformações da economia global, notadamente aquelas vinculadas à formação das cadeias de valor, bem como à inclusão do tratamento de barreiras não tarifárias e dos "novos temas" em seu marco regulatório.

A expansão de temas essencialmente políticos dentro da agenda de integração sul-americana, em princípio, não logrou uma significativa melhora da integração produtiva e infraestrutural. Além disso, o Mercosul afastou-se em parte dos objetivos traçados no Tratado de Assunção para a formação de um mercado comum, resultando na sua parcial multifuncionalidade, desvirtuando-o de seus objetivos econômicocomerciais e da liberalização contínua. Esse fato contribuiu para o arrefecimento de opções estratégicas de inserção internacional do Brasil, além de o bloco regional ter avançado pouco em termos relativos a outros projetos de integração na constituição de um processo virtuoso que contenha o "efeito multiplicador regional", tal qual como existe no Leste Asiático. Além disso, o perfil de liderança brasileira exercido até aqui não corresponde ao demandado para construção de uma cadeia regional de valor.

A bonança externa vivida pelo País pelo menos até 2011 - em grande parte resultante do cenário internacional favorável, como as taxas de juros internacionais baixas e melhoria significativa nos termos de troca - induziu uma espécie de "efeito colateral" à economia nacional, com acomodação brasileira aos influxos da década anterior. Mas com resultado, houve também um aumento dos custos de produção na indústria de transformação, a qual não continha um plano de ação devidamente deliberado de inserção externa.

A inserção internacional do Brasil parece ter vínculo direto com o cenário econômico internacional e com o ambiente econômico doméstico. O País deixou de aproveitar um momento muito favorável para a adoção de reformas pró-produtividade e para a assinatura de acordos com mercados relevantes, o que poderia sustentar de forma mais eficaz sua emergência e o crescimento econômico. Além disso, a temida primarização da pauta brasileira de exportações e perda de competitividade industrial, as 
quais eram justificativas domésticas corriqueiramente levantadas para o bloqueio de acordos com nações desenvolvidas, vieram a ocorrer sem a assinatura dos acordos.

As evidências empíricas apresentadas sugerem que o Brasil deva adotar um modelo econômico mais outward-looking em termos econômicos, a fim de evitar o isolamento produtivo e comercial e de se tornar demasiadamente dependente do mercado interno e regional para as exportações de bens de valor agregado. As reduções de preferências comerciais em mercados tradicionais brasileiros só aumentam a necessidade de buscar novos mercados.

Os desafios são muito maiores para o País diante dos novos padrões de comércio e de produção internacional, bem como da emergência dos mega acordos que formarão um lócus de produção de regras globais, dos quais o Brasil permanece à margem. Essa é uma modificação na histórica participação ativa do País como rule-maker no comércio internacional. A proliferação de acordos e as cadeias de valor impactam consideravelmente a política internacional contemporânea, além de alterarem a configuração internacional na qual os Estados devem se basear para a consecução de seus interesses. No mundo interdependente, nenhum país estará totalmente isolado das dinâmicas da economia internacional, seja por meio de uma participação ativa ou passiva.

O Brasil é um grande exemplo de país que, ao tentar se fechar parcialmente ao fenômeno da globalização e da interdependência econômica sofre consequências paradoxais em relação a esses fenômenos justamente por participar marginalmente do processo, tais como custos mais altos de produção por barreiras a importações de bens intermediários; (BAUMANN, 2013b; 2014a); número muito limitado de acordos comerciais, o que restringiu o acesso a mercados mais sofisticados, em especial, no momento em que são negociados os mega-acordos preferenciais (THORSTENSEN; FERRAZ, 2014); o fato de ter vivido uma bonança externa temporária sem saber se preparar para o momento posterior, findado o seu efeito mais benéfico, não conseguindo elevar consideravelmente a taxa de investimento na base do desenvolvimento (BACHA, 2014; GIAMBIAGI; SCHWARTSMAN, 2014); e acesso tardio a novas sofisticações tecnológicas na maioria dos setores econômicos (com exceção de aeronáutica, agricultura e exploração de petróleo em águas profundas) (STURGEON; et al, 2014; CANUTO, 2014a).

O destaque internacional recebido pelo Brasil apresenta um paradoxo. Comparando-se a experiência brasileira com os demais países emergentes e os já 
desenvolvidos, nota-se que o País pouco avançou em termos de integração econômica global e regional relativa. Alguns indicadores corroboram esse fato: a baixa participação do comércio sobre o PIB; a relativa baixa participação no comércio internacional; a baixa participação nas Cadeias Globais de Valor, que representam os novos padrões de comércio; isolamento do país nos acordos bilaterais e mega acordos preferenciais de comércio; e, dificuldades institucionais, econômicas, de negociações extrabloco no Mercosul.

Argumentou-se que há um path dependence quanto a essa baixa participação do Brasil em termos de integração econômica internacional, em especial da indústria de transformação, resultando em custos de oportunidade crescentes com o passar do tempo, um processo de complexa reversão.

Quadro 6 - Linha do tempo da emergência do Brasil 2001 a 2014

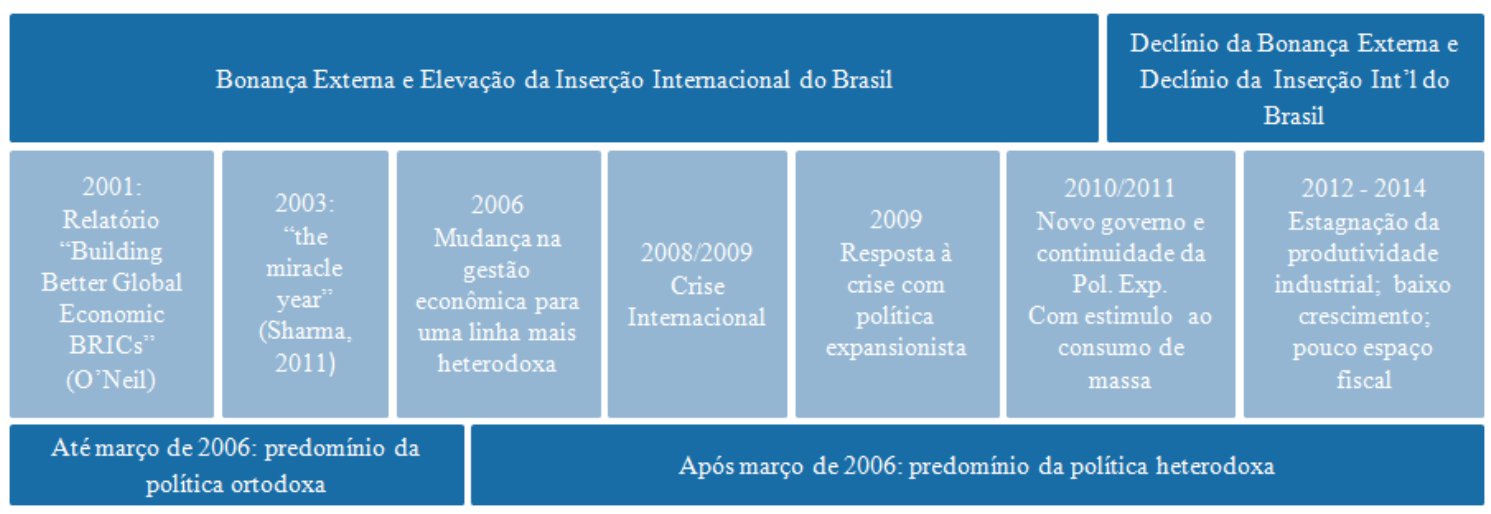

Fonte: elaboração própria.

Dentre os fatores domésticos que contribuem para marginalizar a economia brasileira das principais dinâmicas globais, destaca-se a proteção do mercado interno via proteção tarifária e não tarifária (MARKWALD, 2014) para a importação de bens de capital e bens intermediários, essenciais para a uma participação em processos de integração em cadeias de valor. O alto custo-Brasil é um fator limitador para a competitividade industrial. Como reforço da s políticas anticíclicas adotadas período da crise internacional de 2009, o governo brasileiro optou por instrumentos keynesianos para conter o efeito desacelerador na economia nacional a partir de 2011, e não de formação da base do crescimento de longo prazo, como maiores taxas de investimento. O Brasil possui o desafio de aumentar a produção quando o teto da capacidade instalada se aproximar. Por isso é necessário investir. 
Além do fato de a participação do comércio sobre o PIB no Brasil ser extremamente baixa, o pouco que o país comercializa com o resto do mundo está pouco integrado às cadeias de valor, fontes de eficiência e de escala para a indústria. Diante da importância do setor industrial para a economia brasileira e a necessidade de se inserir nos mercados globais mais sofisticados para tornar a indústria nacional mais competitiva, o Brasil deve trabalhar para criar condições para uma economia de mercado aberta e dar uma maior ênfase no aspecto econômico em sua política externa com os vizinhos da América do Sul.

Algumas recomendações políticas tornam-se emergenciais: negociações de acordos com mercados mais sofisticados do globo, a fim de se obter maior acesso para as exportações brasileiras; maior ênfase no comércio exterior para permitir um desenvolvimento de longo prazo, permitindo uma maior aquisição de conteúdo tecnológico e ganho de competitividade das exportações; maior eficiência da produção nacional, e permitir ganhos de economia de escala; adoção de um cronograma de abertura comercial, em especial, para bens de produção, permitindo também um aumento das importações a fim de procurar reduzir pressões inflacionárias no país, e pressionar firmas locais para o aumento da eficiência; e maior ênfase nos aspectos econômicos, comerciais e produtivos no Mercosul, bem como fortificar mecanismos institucionais de cumprimentos das regras regionais, de modo a facilitar a formação de mecanismos de complementaridade produtiva que visem à formação de cadeias regionais de valor e não simplesmente uma "fortaleza comercial".

Diante disso, é necessária a adoção de política doméstica em prol do desenvolvimento de longo prazo pelo Brasil, bem como não se deve relegar ou subestimar a temática comercial na ação externa, o que seria muito custoso em termos de oportunidade. Perante a experiência internacional do pós-segunda guerra dos países emergentes, a integração internacional é uma condição indispensável para a superação da "armadilha da classe média". Integrar-se na economia global é um pré-requisito essencial para o crescimento de economias não desenvolvidas (SPENCE, 2010, p. 4). Além disso, muitos custos e contrapartidas da integração são inevitáveis. Como afirma Frieden (2008, p. 500), "não há comércio sem concorrência, finanças sem riscos, bem como não há investimentos sem obrigações”. É necessário que o Brasil repense sua política comercial externa. 


\section{REFERÊNCIAS}

ABDENUR, Roberto. "China, café, SGP. E a danada da ALCA...". In: CEBRI (Various Authors). A Inserção do Brasil nas Cadeias Globais de Valor. Dossiê, Edição Especial, vol. 2, ano 13, 2014. p. 52 - 56.

ABDENUR, Roberto. "Para exportar mais, mais política externa", Folha de São Paulo, Opinião, 28 jan. 2015.2 Disponível em: <http://www1.folha.uol.com.br/opiniao/2015/01/1581419-roberto-abdenur-paraexportar-mais-mais-politica-externa.shtml>. Acesso em: 20 fev. 2015.

ABDI. Política Industrial. Agência Brasileira de Desenvolvimento Industrial. Disponível em: <http://www.abdi.com.br/Paginas/politica_industrial.aspx>. Acesso em: 30 jan. 2015.

ABREU, Marcelo de Paiva. "Saudade do Itamaraty prudente", O Estado de São Paulo, 04 de março de 2015. Disponível em: $<$ http://economia.estadao.com.br/noticias/geral,saudade-do-itamaraty-prudenteimp-,1643947>. Acesso em: 02 mar. 2015.

ABREU, Marcelo de Paiva. Comércio Exterior: interesses do Brasil. Rio de Janeiro: Elsevier, 2007.

AGÉNOR, Pierre-Richard; CANUTO Otaviano; JELENIC, Michael. Avoiding MiddleIncome Growth Traps. Economic Premise, World Bank, n. 98, nov. 2012.

ALIANZA DEL PACÍFICO SITE. Disponível em: <http://alianzapacifico.net/paises/paises-observadores/>. Acesso em: 10 fev. 2015.

ALMEIDA, Paulo Roberto de. Integração Regional: uma introdução. São Paulo: Saraiva, 173 p. Coleção Temas Essenciais em R.I, 2013a.

A Política Externa das Relações Sul-Sul: um Novo Determinismo Geográfico?. Revista Acadêmica Espaço da Sophia, v. 47, 1. ed. Tomazina (PR): Editora Espaço da Sophia, jan./jun. 2013b, p. 163-188.

EUA e UE Negociam una Super Zona de Livre Comércio. Belo Horizonte: $O$ Debatedouro, ano 12, nº1, edição 82, v. 12, mar. 2013c, p. 33-37.

.Sovereignty and Regional Integration in Latin America: A Political Conundrum. Contexto Internacional, vol. 35, n. 2, jul./dez. 2013d, p. 471-495.

ALVIM, André; RIZZO, Paula. Comércio Exterior: quatro temas para debate. Revista Brasileira de Comércio Exterior, n. 120, set. 2014. Disponível em: <http://www.funcex.org.br/publicacoes/rbce/material/rbce/120_AAPR.pdf>. Acesso em: 27 fev. 2015.

AMADOR, João; CABRAL, Sónia. Global Value Chains: Surveying Drivers and Measures. Working Paper Series no 1239. European Central Bank, october 2014. Disponível em: <http://www.ecb.europa.eu/pub/pdf/scpwps/ecbwp1739.en.pdf>. Acesso em: 25 fev. 2015. 
AMARAL, Sergio. 'Uma diplomacia comercial para o século XXI'. Revista Brasileira de Comércio Exterior, n. 117, Outubro - Dezembro de 2013, p. 24 - 31.

AMATO, Fábio. "Balança comercial registra em 2014 primeiro déficit desde 2000". G1 Portal de Notícias. Brasília, 05 jan. 2015. Disponível em: <http://g1.globo.com/economia/noticia/2015/01/balanca-comercial-registra-em2014-primeiro-deficit-desde-2000.html:>. Acesso em: 29 jan. 2015

AMORIM, Celso. "Brazilian Foreign Policy under President Lula (2003-2010): an overview". Revista Brasileira de Política Internacional, vol. 53 (special edition), p. $214-240,2010$.

ANTWEILER, W.; TREFLER, D. "Increasing Returns and All That: A View from Trade". NBER Working Paper, 7941, 2000. Disponível em <http://www.nber.org/papers/w7941> Acesso em 23/04/14.

ARAUJO Jr, José Tavares de. Fragmentação da produção e competitividade internacional: o caso brasileiro. Revista Brasileira de Comércio Exterior, no 115 , Abril - Junho de 2013, p. 42 - 51. Disponível em: < http://www.funcex.org.br/publicacoes/rbce/material/rbce/115_JTA.pdf.pdf>.

Acesso em: 23 out. 2014.

AZEVEDO, Roberto. "O Brasil não pode se confinar à América do Sul". Site Revista Época, 29 mar. 2014. Entrevista concedida a Marcos Coronato. Disponível em:< http://epoca.globo.com/tempo/noticia/2014/03/broberto-azevedob-o-brasil-naopode-se-confinar-america-do-sul.html>. Acesso em: 20 jan. 2015.

BACHA, Edmar. 'Integrar para crescer: o Brasil na economia mundial'. Revista Brasileira de Comércio Exterior, n. 118, Janeiro - Março de 2014, p. 4 - 13.

BACHA, Edmar; BAUMGARTEN, Monica B. (orgs.). O Futuro da Indústria no Brasil: desindustrialização em debate [recurso eletrônico]. Rio de Janeiro: Ed. Civilização Brasileira, 2013.

BACKER, Koen D. The rise of global value chains: what are they and how is value distributed within them. Presentation. In: OECD-KDI Workshop on Global Value Chains, development and competitiveness. Apresentação. Paris, 27 nov. 2013.

BALASSA, Bela. The Theory of Economic Integration. Homewood, IL: Richard Irwin., 1962.

BALDWIN, Richard LOPEZ-GONZALEZ. "Supply-Chain Trade: A Portrait of Global Patterns and Several Testable Hypotheses", manuscrito, 2012.

BALDWIN, Richard WTO 2.0: Global Governance of Supply Chain Trade. CEPR, Policy Insight No .64 , Dez. 2012.

BALDWIN, Richard. "Global Supply Chains: Why they Emerged? Why they Matter? And Where they are Going?" In: ELMS, Deborah K.; LOW, Patrick. (eds). Global value chains in a changing World. WTO. Geneva: WTO, Fung Global Institute (FGI), Nanyang Technological University (NTU), 2013, p. 13-60. Disponível em: <http://www.wto.org/english/res_e/booksp_e/ aid4tradeglobalvalue13_e.pdf $>$. Acesso em: 17 nov. 2014. 
BALDWIN, Richard. Trade and Industrialisation after Globalisation's 2nd Unbundling: how building and joining a supply chain are different and why it matters. Working Paper 17716. Cambridge, MA: National Bureau of Economic Research (NBER), dez. 2011. Disponível em: < http://www.nber.org/papers/w17716>. Acesso em: 18 fev. 2015.

BARBOSA, Rubens. "Mercosul: retórica e realidade". Política Externa, vol. 22, n. 4, abr/mai/jun. 2014, p. 17 - 27.

. "O Brasil fora das cadeias produtivas globais". Revista Interesse Nacional, 13 jul. 2013. Opinião. Disponível em: $<$ http://interessenacional.uol.com.br/index.php/em-destaque/o-brasil-fora-dascadeias-produtivas-globais-2/>. Acesso em: 08 out. 2014.

BAUMANN, Renato. Integração Regional: Teoria e Experiência Latino-Americana. Rio de Janeiro: LTC, 2013a, p. 60-63.

Política comercial externa brasileira: algumas considerações para a indústria. Fundação Getúlio Vargas, 2013b. Disponível em: <http://eesp.fgv.br/sites/eesp.fgv.br/files/file/POL\%C3\%8DTICA\%20COMERCI AL\%20E\%20CAMBIAL\%20-\%20RENATO\%20BAUMANN.pdf >. Acesso em: 23 out. 2014.

"Brazilian, Chinese, and Indian exports: is the regional market really a source of learning?". Brazilian Journal of Political Economy, vol. 33, n. 1, pp. 102-119, jan/mar. 2013c.

"O Brasil e as cadeias globais de valor". In: CEBRI (Various Authors). A Inserção do Brasil nas Cadeias Globais de Valor. Dossiê, Edição Especial, v. 2, ano $13,2014 \mathrm{a}$

'Choveu sopa e o Brasil ficou de garfo na mão'. entrevista. Brasil Econômico, 30 jul. 2014b. Entrevista concedida a Sonia Filgueiras. Disponível em: $<$ http://brasileconomico.ig.com.br/brasil/economia/2014-07-30/choveu-sopa-e-obrasil-ficou-de-garfo-na-mao-diz-renato-baumann-do-ipea.html>. Acesso em: 04 fev. 2015.

BAUMANN, Renato; GONÇALVES, Reinaldo; CANUTO, Otaviano. Economia Internacional: teoria e experiência brasileira. Rio de Janeiro: Campus, 2004.

BAUMANN, R.; NG, F. 'Regional productive complementarity and competitiveness'. International Trade Journal, vol. 26, n. 4, p. 326-359, 2012. Disponível em: <http://eesp.fgv.br/sites/eesp.fgv.br/files/file/POL\%C3\%8DTICA\%20COMERCI AL\%20E\%20CAMBIAL\%20-\%20RENATO\%20BAUMANN.pdf>. Acesso em: 23 out. 2014.

BBC BRASIL. "América Latina vive onda protecionista liderada por Brasil e Argentina, diz estudo". 14/Julho de 2012. Disponível em:<http://www.bbc.co.uk/portuguese/noticias/2012/06/120614_protecionismo_1 atam_lgb.shtml> Acesso em 20 Jul. 2013. 
BERGGRUEN, Nicolas; GARDELS, Nathan. Governança Inteligente para o Século XXI: uma Via Intermediária entre Ocidente e Oriente. Rio de Janeiro: Ed. Objetiva, 2013, 247p.

BERNANKE, Ben S. "Germany's trade surplus is a problem", Brookings, 3 abr. 2015. Disponível em: <http://www.brookings.edu/blogs/benbernanke/posts/2015/04/03-germany-trade-surplus-problem>. Acesso em: $10 \mathrm{abr}$. 2015.

BHAGWATI, Jagdish. In Defense of Globalization. New York: Oxford University Press, 2004.

."Protectionism". The Concise Encyclopedia of Economics. David R. Henderson, ed. Originally published as The Fortune Encyclopedia of Economics, Warner Books. 1993. Library of Economics and Liberty [Online]. Disponível em: <http://www.econlib.org/library/Enc1/Protectionism.html>. Acesso em: 08 out. 2014.

. "Why Free Trade Matters", Project Syndicate, 23 jun. 2011. Disponível em: <http://www.project-syndicate.org/commentary/why-free-trade-matters>. Acesso em 08 out. 2014.

. Dawn of a New System, Finance \& Development, v. 50, n 4. dec. 2013.

BHAGWATI, Jagdish.; PANAGARIYA, Arvind. Why Growth Matters: How Economic Growth in India Reduced Poverty and the Lessons for Other Developing Countries. New York: Public Affairs, 2013.

BONOMO, Diego. Sem deixar a peteca cair: o Brasil e os contenciosos na OMC. Pontes (Bridges Networks), v. 10, n. 6, ago. 2014. p. 4-8.

BRASIL. Plano Brasil Maior: Inovar para Competir. Competir para Crescer. Plano 2011/2014. Texto de Referência.

BRYNJOLFSSON, Erik; McAFEE, Andrew; SPENCE, Michael. 'New World Order: Labor, Capital, and Ideas in the Power Law Economy'. Foreign Affairs, jul/ago. 2014.

BURGES, Sean. "Seria o Itamaraty um problema para a política externa brasileira?". Política Externa, 01 nov. 2012.

BUZAN, Barry. A World Order Without Superpowers: Decentred Globalism. The Inaugural Kenneth N. Waltz Annual Lecture, 25(1), 2011 p. 3-25.

CALDER, Kent; FUKUYAMA, Francis. Multilateralismo na Ásia Oriental: perspectivas para a estabilidade regional. Rio de Janeiro: Rocco, 2012. p. 292316.

CANUTO, Otaviano. "A Alta Densidade das Cadeias de Produção no Brasil". In: CEBRI (Various Authors). A Inserção do Brasil nas Cadeias Globais de Valor. Dossiê, Edição Especial, vol. 2, ano 13, 2014a, p. 40 - 46.

. How can Brazil scape the middle-income trap?, Site World Economic Forum.

Global Financial System. 25 fev. 2014b. Disponível 
em: $<$ https://agenda.weforum.org/2014/02/can-brazil-escape-middle-incometrap/>. Acesso em: 30 fev. 2015.

'Agenda de reformas perdeu fôlego', $O$ Globo, 2 fev. 2015. Disponível em: $<$ http://oglobo.globo.com/economia/infraestrutura/otaviano-canuto-agenda-dereformas-perdeu-folego-15214167>. Acesso em: 30 jan. 2015.

CARDOSO, Fernando H.; FALETTO, Enzo. Dependency and Development in Latin America. Translated by Marjory Mattingly Urquidi. Berkeley; Los Angeles; London: University of California Press, 1979.

CARDOSO, Renato Fragelli. Política econômica, reformas institucionais e crescimento: a experiência brasileira (1945-2010). In: VELOSO, Fernando. et al. (Org.). Desenvolvimento Econômico: uma Perspectiva Brasileira. $1^{\mathrm{a}}$ ed. Rio de Janeiro: Elsevier, 2013. p. 166 - 2010.

CARR, Edward Hallet. Vinte Anos de Crise. Brasília: Ed. Universidade de Brasília. p. 18 Disponível em <http://funag.gov.br/loja/download/40-Vinte_Anos_de_Crise__1919-1939.pdf>. Acesso em: 29 jan. 2015.

CEPAL. El Arco Del Pacífico Latinoamericano Después de la Crisis: Desafíos y Propuestas. Santiago/Chile: Naciones Unidas, nov. 2009. Disponível em <http://www.eclac.org/comercio/publicaciones/xml/9/37939/Arco_del_Pacifico_L atinoamericano.pdf $>$. Acesso em: 16 jun. 2014.

- El regionalismo abierto en América Latina y el Caribe. La integración económica al servicio de la transformación productiva con equidad, Santiago de Chile, enero de 1994.

Los desafíos de América Latina y el Caribe para mejorar su inserción en la economía mundial. Panorama de la inserción internacional de América Latina y el Caribe - 2010-2011. Capítulo III.

CERVO, Amado Luiz. Relações Internacionais da América Latina: de 1930 aos nossos dias. 3. ed. rev. e atual. São Paulo: Saraiva; Instituto Brasileiro de Relações Internacionais, 2013.

CERVO, Amado L.; LESSA, Antônio C. O declínio: inserção internacional do Brasil (2011-2014). Revista Brasileira de Política Internacional, v. 57, n. 2, p. 133-151, 2014. Disponível em: <http://www.scielo.br/pdf/rbpi/v57n2/0034-7329-rbpi-5702-00133.pdf>. Acesso em: 19 fev. 2015.

CHADE, Jamil. União Europeia aciona a OMC contra os incentivos industriais no Brasil. O Estado de São Paulo. Genebra: 31 out. 2014. Disponível em: $<$ http://economia.estadao.com.br/noticias/geral,uniao-europeia-aciona-a-omccontra-os-incentivos-industriais-do-brasil,1586188>. Acesso em 04 nov. 2014.

CHANG, Ha-Joon. Kicking Away the Ladder: Development Strategy in Historical Perspective. London: Anthem Press, 2002.

COLLIER, Paul; DOLLAR, David. Globalization, Growth, and Poverty: Building an Inclusive World Economy. Under the supervision of Nicholas Stern. Washington: World Bank Publication, Oxford University Press, 2002. 
COMISSÃO EUROPEIA. Compreender as políticas da União Europeia: Comércio. União Europeia. Luxemburgo: Serviço das Publicações da União Europeia, 2014. Disponível em: <http://europa.eu/pol/pdf/flipbook/pt/trade_pt.pdf>. Acesso em 07 jan. 2015.

CONFEDERAÇÃO NACIONAL DA INDÚSTRIA. Competitividade Brasil 2014: Comparação Com Países Selecionados. Brasília: CNI, 2015. Disponível em: $<$ http://www.portaldaindustria.com.br/cni/publicacoes-eestatisticas/estatisticas/2015/01/1,42616/competitividade-brasil-comparacao-compaises-selecionados.html>. Acesso em 20 jan. 2015.

CRUZ, Adriana Inhudes G. et al. A Economia Brasileira: conquistas dos últimos dez anos e perspectivas para o futuro. BNDES, out. 2012. Disponível em: <http://www.bndes.gov.br/SiteBNDES/export/sites/default/bndes_pt/Galerias/Arq uivos/conhecimento/livro60anos_perspectivas_setoriais/Setorial60anos_VOL1Ec onomiaBrasileira.pdf>. Acesso em: 20 jan. 2015.

DATAMYNE. Quick Look: Pacific Alliance Trade, 2012. Disponível em: <http://www.datamyne.com/free-report-library./_>. Acesso em 10 de agosto de 2013.

DEVLIN, Robert; GIORDANO, Paolo. The Old and New Regionalism: Benefits, Costs, and Implications for the FTAA. In: ESTEVADEORDAL, Antoni. et al. (Org). Integrating the Americas: FTAA and Beyond. Cambridge, Massachusetts; London, England: Harvard University, David Rockefeller-Center for Latin American Studies, 2004.

DOMINGUES, Reinaldo Alencar. O Perfil do Brasil como Potência Regional SulAmericana no Governo Lula (2003-2010). 2013. 108 f. Dissertação (Mestrado em Relações Internacionais) - Universidade de Brasília, Brasília, 2013.

EDWARDS, Sebastián. Openness, productivity and growth: what do we really know? National Bureau of Economic Researrch, working paper n. 5.978, 1997.

ELMS, Deborah K.; LOW, Patrick. (eds). Global value chains in a changing World. WTO. Geneva: WTO, Fung Global Institute (FGI), Nanyang Technological University (NTU), 2013. Disponível em: < http://www.wto.org/english/res_e/booksp_e/aid4tradeglobalvalue13_e.pdf>.

Acesso em: 17 nov. 2014.

ESTEVADEORDAL, Antoni. "Economic Integration in the Americas: An Unfinished Agenda". In: PICCONE, Ted. et al. (eds.). The Road to Hemispheric Cooperation: Beyond the Cartagena Summit of the Americas. Washington, D.C.: The Brookings Institution, July 2012.

ESTEVADEORDAL, A. BLYDE, J. SUOMINEN, K. 'As cadeias globais de valor são realmente globais?' Políticas para acelerar o acesso dos países às redes de produção internacionais. Revista Brasileira de Comércio Exterior, $\mathrm{n}^{\circ} 115$, Abril Junho de 2013, p. 6 - 25. Disponível em: < http://www.funcex.org.br/publicacoes/rbce/material/rbce/115_AEJBKS.pdf.pdf>. Acesso em: 23 out. 2014. 
ESTEVADEORDAL, Antoni; SUOMINEM, Kati. The Sovrereingty Remedy? Trade Agreements in a Globalizing World. New York: Oxford University Press, 2009.

EUROPEAN COMISSION SITE. European Union, Trade in goods with USA. Statistics. Directorate-General for Trade, 17 ago. 2014. Disponível em: <http://trade.ec.europa.eu/doclib/docs/2006/september/tradoc_113465.pdf〉. Acesso em: 15 jan. 2015.

EXAME. Nintendo encerra distribuição de consoles e games no Brasil. 09 jan. 2015. Disponível em: <http://exame.abril.com.br/negocios/noticias/nintendo-encerradistribuicao-de-consoles-e-games-no-brasil>. Acesso em: 30 jan. 2015.

FEENSTRA, Robert C. 'Integration of Trade and Desintegration of Production in the Global Economy'. The Journal of Economic Perspectives, vol. 12, n. 4, Auntumn 1998, p. 31-50.

FIESP NOTÍCIAS. "Brasil cresce pouco porque modelo de 2005 a 2010 não existe mais", $02 \quad$ jun. $2014 . \quad$ Disponível em: <http://www.fiesp.com.br/mobile/noticia/?id=154309>. Acesso em: 10 mar. 2015

FIESP. Documento de Posição: Agenda de Integração Externa - 2014. São Paulo, jun. 2013.

FIESP. Documento de Posição: Propostas de Integração Externa da Indústria - 2014. São Paulo, jun. 2014.

FINANCIAL TIMES. "Global companies benefit from taking a long term view on local production". 22 jan. 2014.

FRIEDEN, Jeffry. Capitalismo Global: história econômica e política do século XX. Tradução Vivian Mannheimer. Rio de Janeiro: Jorge Zahar Ed., 2008. 573 pp.

FRIEDEN, Jeffry; MARTIN, Lisa. International Political Economy: Global And Domestic Interactions. In: KATZNELSON, Ira; MILNER, Helen. Political Science: The State of the Discipline. New York: W.W. Norton, 2003.

FRIEDMAN, Thomas. The World is Flat: A Brief History of the Twenty-first Century. New York: Picador Trade Paperback, 2007.

FUNCEX. Disponível em: <http://www.funcexdata.com.br/br /notas/nv2_indicettroca.pdf>. Acesso em 23 fev. 2015.

G1 PORTAL DE NOTÍCIAS. Coreia do Norte afirma estar em 'estado de guerra' com Coreia do Sul. São Paulo: G1Mundo, 29 mar. 2013. Disponível em: <http://g1.globo.com/mundo/noticia/2013/03/coreia-do-norte-afirma-estar-emestado-de-guerra-com-coreia-do-sul.html>. Acesso em: 07 jan. 2015.

GARCIA, Marco Aurélio. "A Opção Sul-Americana". São Paulo: Interesse Nacional, ano 1, edição 1 , abril/junho, 2008, p. 22-28.

GEREFFI, G. et al. Globalisation, Value Chains and Development. Institute of Development Studies Bulletin, v. 32 , n. 3, 2001. 
GIAMBIAGI, Fábio; ALMEIDA, Paulo R. Morte do Consenso e Washington? Os rumores a esse respeito parecem muito exagerados. BNDES, Texto para Discussão $\mathrm{n}^{\mathrm{o}}$ 103, Rio de Janeiro, out. 2003.

GIAMBIAGI, Fábio; SCHWARTSMAN, Alexandre. Complacência: Entenda por que o Brasil cresce menos do que pode. Rio de Janeiro: Ed. Elsevier, 2014, p. 135 - 148.

GILPIN, Robert. The Political Economy of International Relations. Princeton: Princeton University Press, 1987, 449 pp.

Global Political Economy: Understanding the International Economic Order. With the Assistance of Jean Gilpin. New Jersey/Oxford: Princeton University Press, 2001,423 pp.

GODINHO, Daniel; DOMINGUES, Gustavo C. Acessão da Rússia à OMC: notícia a ser comemorada. Pontes, v. 8, n. 1, 2 fev. 2012. Disponível em: http://www.ictsd.org/bridges-news/pontes/news/acess\%C3\%A3o-dar\%C3\%BAssia-\%C3\%A0-omc-not\%C3\%ADcia-a-ser-comemorada>. Acesso em 04 jan. 2015.

GONÇALVES, Reinaldo. 'Competitividade internacional e integração regional: a hipótese da inserção regressiva'. Revista de Economia Contemporânea. Rio de Janeiro, v. 5, n. especial, p. 13-34, 2001.

GORE, Al. The Future: Six drivers for global change. New York: Random House, 2013.

GRIFFITH-JONES, Stephany; OCAMPO, José Antonio. "The Financial Crisis and its Impact on Developing Countries." International Policy Centre for Inclusive Growth. Working Paper, n. 53, abr. 2009. Disponível em: <http://www.ipcundp.org/pub/IPCWorkingPaper53.pdf>. Acesso em: 13 nov. 2014.

GRIFFITHS, Rudyard. (ed.). Does the 21st Century Belong to China? Kissinger and Zakaria vs. Ferguson and Li: the Munk debate on China. Toronto: Anansi, 2011.

GUIMARÃES, Samuel Pinheiro. "A União Europeia e o fim do Mercosul", Carta Maior, 26 abr. 2014. Disponível em: $<$ http://www.cartamaior.com.br/?/Editoria/Internacional/A-Uniao-Europeia-e-ofim-do-Mercosul/6/30799>. Acesso em: 23 jan. 2015.

A perspectiva brasileira de integração sul-americana. In: FUNDAÇÃO ALEXANDRE GUSMÃO. (Vários Autores). A América do Sul e a Integração Regional. Brasília: FUNAG, 2012. p. 93 - 96. Disponível em: <http://www.funag.gov.br/biblioteca/dmdocuments/America_do_Sul_e_A_Integr acao_Regional.pdf>. Acesso em: 08 jan. 2015.

HEAKAL, Reem. "What Is An Emerging Market Economy?". Investopedia Site. Disponível em: <http://www.investopedia.com/articles/03/073003.asp>. Acesso em: 20 jan. 2015.

HELD, David; McGREW, Anthony. (eds). The Global Transformations Reader: An Introduction to the Globalization Debate. 2 ed. Malden, MA: Polity Press, 2003. 
The Great Globalization on Debate: An Introduction. In: HELD, David; McGREW, Anthony. (eds). The Global Transformations Reader: An Introduction to the Globalization Debate. 2 ed. Malden, MA: Polity Press, 2003.

HELPMAN, E. "Increasing Returns, Imperfect Markets and Trade Theory". In: JONES, R; KENEN, P. (eds). Handbook of International Economics. North Holland, 1984, vol I.

HURRELL, Andrew. On Global Order: Power, Values, and the Constitution of International Society. Oxford University Press, 2009, 336 pp.

depoiment. In: ARNSON, Cynthia; SOTERO, Paulo. (eds.). Brazil as a Regional Power: Views from the Hemisphere. Washington, D.C.: Woodrow Wilson International Center for Scholars/Latin America Program and Brazil Institute, 2010. p. 5-6. Disponível em: <http://www.wilsoncenter.org/sites/default/files/WWC_Brazil-Institute-Reportupdated\%200926101.pdf >. Acesso em: 27 dez. 2014.

IAPADRE, P. Lelio; TAJOLI, Lucia. 'Emerging countries and trade regionalization: a network analysis'. Journal of Policy Modeling, vol. 36, suplement 1, p. 89 - 110.

IMF. World Economic Outlook (WEO): Legacies, Clouds, Uncertainties. Washington: International Monetary Fund, October 2014. Chapter 2: Country and Regional Perspectives. Disponível em: <http://www.imf.org/external/pubs/ft/weo/2014/02/pdf/c2.pdf>. Acesso em: 07 jan. 2015.

INTER-AMERICAN DEVELOPMENT BANK (IDB). 'Mega-agreement negotiations: how will they influence Latin America?'. Monthly Newsletter, n. 204, ago. 2013. Disponível em: <http://www10.iadb.org/intal/cartamensual/Cartas/ Articulo.aspx? Id=d556f56e-6ac2-4673-bc1e-e922e4e9ea08\&lang=en>. Acesso em: 23 out. 2014.

IPEA Integração às Cadeias Globais Favorece Industrialização. 06 fev. 2014. Disponível em: $<$ http://www.ipea.gov.br/portal/index.php?option=com_content\&view=article $\&$ id=21327 $>$. Acesso em 14/05/2014.

IPEA. Os venezuelanos estão chegando. Ano 9, ed. 74, 31 out. 2012. Disponível em: $<$ http://www.ipea.gov.br/desafios/index.php?option=com_content\&view=article\& $\mathrm{id}=2826$ : catid=28\&Itemid=23>. Acesso em: 03 mar. 2015.

JACOBS, Lindsay M; ROSSEM Ronan V. "The BRIC Phantom: A comparative analysis of the BRICs as a category of rising powers", Journal of Policy Modeling, vol. 36, n. 1, p. 47-66, 2014 Disponível em: <http://www.sciencedirect.com/science/article/pii/S0161893813001038>. Acesso em: 08 out. 2014.

JOHNSON, Janet B.; REYNOLDS, Henry, T. Political Science Research Methods. 7th ed. Washington, D.C.: CQ Press. 
JONES, Emily. 'The WTO's Reform Crisis'. Project Syndicate, 23 out. 2014. Disponível em: <http://www.project-syndicate.org/commentary/wto-reformcrisis-by-emily-jones-2014-10>. Acesso em: 24 out. 2014.

KAPLINSKY, Raphael. Spreading the gains from globalisation: what can be learned from value chains analysis?. Brighton : Inst. of Development Studies, Working Paper 110, 2000.

KATZENSTEIN, P. J.; KEOHANE, R. O.; KRASNER, S. D. "International Organization and the Study of World Politics". International Organization, vol. 52, n. 4, Autumn 1998, p. 645-685.

KEOHANE, Robert O. 'The old IPE and the new'. Review of International Political Economy, vol. 16, n. 1, February 2009, p. 24-36.

KEOHANE, Robert O.; MILNER, Helen V. (eds). Internationalization and Domestic Politics. New York: Cambridge University Press, 1996. p. 3-24.

KEOHANE, Robert O.; NYE Jr, Joseph S. "Power and Interdependence in the Information Age". Foreign Affairs, set/out. 1998. Disponível em: $<$ http://www.foreignaffairs.com/articles/54395/robert-o-keohane-and-joseph-snye-jr/power-and-interdependence-in-the-information-age >. Acesso em: 08 out. 2014.

KINDLEBERGER, Charlie P; ALIBER, Robert Z. Manias, Pânicos e Crises: A História das Catástrofes Econômicas Mundiais. 6ed. 2013.

KISSINGER, Henry A. China: containment won't work. The Washington Post. 13 jun. 2005. Disponível em: [http://www.washingtonpost.com/wpdyn/content/article/2005/06/12/ AR2005061201533.html]. Acesso em: 03 jun. 2014.

KRUGMAN, Paul. "Increasing Monopolistic Competition and International Trade". Journal of International Economics, 1979, vol.9, No.4.

. "The Increasing Returns Revolution in Trade and Geography". Prize Lecture, December 8, 2008.

KRUGMAN P.; OBSTFELD, M.; MELITZ, Marc J. International Economics: Theory \& Policy. 9th ed. Boston: Addison-Wesley/ Pearson, 2012.

KUME, Honório; PIANI, Guida. Mercosul: o dilema entre união aduaneira e área de livre-comércio. Rev. Econ. Polit., São Paulo, v. 25, n. 4, dec. 2005. Disponível em: $<$ http://www.scielo.br/scielo.php?pid=S0101$31572005000400004 \&$ script=sci_arttext $>$. Acesso em: 20 fev. 2014.

KUPFER, David. Dez anos de política industrial. Valor Econômico, 08 jul. 2013. Disponível em: <http://www.ie.ufrj.br/clipping/download/dezanos.pdf>. Acesso em: 02. fev. 2015.

LAÏDI, Zaki. “The BRICS against the West?” Ceri Strategy Papers, n 11 - Hors Série, Novembre 2011. Disponível em: <http://www.sciencespo.fr/ceri/sites/sciencespo.fr.ceri/files/ n11_112011.pdf>. Acesso em: 12 nov. 2014. 
LAKE, David A. 'Open economy politics: a critical review'. The Review of International Organizations, vol. 4, issue 3, 2009, p. 219-244.

LAMPREIA, Luiz Felipe. As opções internacionais do Brasil. O Estado de São Paulo, 12 de maio de 2013. Disponível em <http://www.estadao.com.br/noticias/impresso,as-opcoes-internacionais-dobrasil,1030964,0.htm>, acesso em 15 de agosto de 2013.

LOPES, Dawisson Belém. A política externa brasileira e a "circunstância democrática": do silêncio respeitoso à politização ruidosa. Revista Brasileira de Política Internacional, Brasília , v. 54, n. 1, p. 67-86, 2011.

MAGNOLI, Demétrio. "Década Perdida". Interesse Nacional, Ano 6, n. 24, jan/mar. 2014, p. $36-41$.

MALAMUD, Andrés. "A Leader Without Followers? The Growing Divergence Between the Regional and Global Performance of Brazilian Foreign Policy". Latin American Politics and Society, vol. 53, Issue 3, ago. 2011.

MARKWALD, Ricardo. 'Inserção do país na economia mundial: qual a singularidade do Brasil?'. Revista Brasileira de Comércio Exterior, n. 118, Janeiro - Março de 2014, p. 14 - 31.

MARTELLO, Alexandre. "Balança comercial tem pior resultado para outubro em 16 anos". Brasília, Site Portal G1 - Economia, 03 nov. 2014. Disponível em: $<$ http://g1.globo.com/economia/noticia/2014/11/balanca-comercial-tem-piorresultado-para-outubro-em-16-anos.html>. Acesso em 10 nov. 2014.

MDIC/SECEX. Balança Comercial Brasileira: dados consolidados. Brasília, 2014. Disponível em: <http://www.mdic.gov.br//arquivos/dwnl_1423144482.pdf>. Acesso em: 07 mar. 2015.

MEACHAM, Carl. Why should the United States join the Pacific Alliance? Center for Strategic \& International Studies (CSIS). 10 jul. 2013. Disponível em: <http://csis.org/publication/why-should-united-states-join-pacific-alliance> Acesso em 10 de agosto de 2013.

MELLO, Patrícia C.; FLECK, Isabel. "Faltam luz e água em embaixadas brasileiras, dizem diplomatas". Folha de São Paulo, 21 jan. 2015. Disponível em: <http://www1.folha.uol.com.br/mundo/2015/01/1578402-faltam-luz-e-agua-emembaixadas-brasileiras-dizem-diplomatas.shtml>. Acesso em: 15 mar. 2015.

MELLO, Pedro Carvalho; SPOLADOR, Humberto F.S. Crises Financeiras: Uma

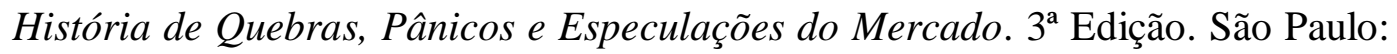
Saint Paul, 2010.

MENEZES, Roberto G. A Aliança do Pacífico e a estratégia de integração SulAmericana do Brasil. IX Encontro da ABCP, Brasília, 04 a 07 ago. 2014.

MEXICO. Unidad de Coordinación de Negociaciones Internacionales: Alianza del Pacífico. Memorias Documentales, Secretaría de Economía. 2012. Disponível em: <http://www.economia.gob.mx/files/transparencia/informe_APF/memorias/6_md _alianza_pacifico_sce.pdf> Acesso em 20 de julho de 2013. 
NADEAU, Paul. 'Conference Summary: Global Value Chains and Development. Part of the Chevron Forum on Development Studies'. CSIS, May 2014. Disponível em: <http://csis.org/files/publication/140506_Nadeau_GlobalValueChains_Web.pdf>. Acesso em: 06 nov. 2014.

NATIONAL INTELliGENCE UNIT (NIU). O Novo Relatório da CIA: Como Será o Mundo Amanhã. Introdução de Heródoto Barbeiro; tradução e notas adicionais Cláudio Blanc. São Paulo: Geração Editorial, 2009.

NEILSON, Jeffrey; PRITCHARD, Bill; YEUNG, Henry Wai-chung. Global Value Chains and global production networks in the changing international political economy: An introduction. Review of International Political Economy, v. 21, n. 1, p. $1-8$.

NEUMANN, Denise et al. "Analistas debatem estratégia comercial do país". Valor Econômico, 12 set. 2014. Disponível em: <http://www.valor.com.br/ brasil/3692562/analistas-debatem-estrategia-comercial-do-pais $>$. Acesso em 08 out. 2014.

NOLTE, Detlef.; WEHNER, Leslie. "The Pacific Alliance Casts Its Cloud over Latin America". Hamburg: German Institute of Global and Area Studies (GIGA), n. 8, 2013.

NYE, Joseph S. Jr. 'What is Power in Global Affairs?'. The Future of Power. New York: Public Affairs, 2011.

O GLOBO. Acordos entre Argentina e China prejudicam o Brasil. Editorial, 22 fev. 2015. Disponível em: <http://oglobo.globo.com/opiniao/acordos-entre-argentinachina-prejudicam-brasil-15400712>. Acesso em 23 fev. 2015.

O'NEILL, Jim. "Is the BRICS rise over?". Bruegel Site - Improving economic policy. Comments. 26 jul. 2014. Disponível em: <http://www.bruegel.org/nc/blog/detail/article/1404-is-the-brics-rise-over/>.

Acesso em: 20 jan. 2015.

O`NEILL, Jim. "Building Better Global Economic BRICs". Goldman Sachs - GS Global Economic Website. Global Economics, Paper no 66, 30 nov. 2001. Disponível em: < http://www.goldmansachs.com/our-thinking/archive/archivepdfs/build-better-brics.pdf >. Acesso em: 15 jan. 2015.

OCDE; WTO; UNCTAD. Implications of Global Value Chains for Trade, Investment, Development and Jobs. 6 aug. 2013. Prepared for the G-20 Leaders Summit Saint Petersburg (Russian Federation), September 2013. Disponível em: <http://www.oecd.org/sti/ind/G20-Global-Value-Chains-2013.pdf >. Acesso em 20 fev. 2015.

ODELL, John S. "Case Study Methods in International Political Economy", International Studies Perspectives, vol. 2, n. 2, p. 161-176, 2001.

OECD. Interconnected Economies: Benefiting from Global Value Chains - Synthesis Report. Paris: OECD Publishing, 2013. Disponível em: <http://www.oecd.org/sti/ind/interconnected-economies-GVCs-synthesis.pdf >. Acesso em: 06 nov. 2014. 
OECD; WTO. Trade in Value-Added:concepts, methodologies and challenges. (Joint OECD-WTO Note). Disponível em: <http://www.oecd.org/sti/ind/49894138.pdf>. Acesso em 10 jan. 2015.

OECD; WTO; UNCTAD. Implications of Global Value Chains for Trade, Investment, Development and Jobs. Prepared for the G20 Leaders Summit. Saint Petersburg (Russian Federation): sep. 2013.

OLIVEIRA, Susan Elizabeth Martins Cesar de. Cadeias globais de valor e os novos padrões de comércio internacional: uma análise comparada das estratégias de inserção de Brasil e Canadá. 2014. 223 f., il. Tese (Doutorado em Relações Internacionais)—Universidade de Brasília, Brasília, 2014.

PALMA, Gabriel. "How the full opening of the capital account to highly liquid financial markets led Latin America to two and a half cycles of "mania, panic and crash'". Cambridge Working Papers in Economics (CWPE), 2011.

"Por que a América Latina não cresce como a Ásia?". BBC Mundo, 13 Jul 2013. Entrevista concedida a Marcelo Justo. Disponível em: <http://www.bbc.co.uk/portuguese/noticias/2012/07/120712_entrevista_america_1 atina_china_lgb.shtml> Acesso em 20 Jul. 2013.

PARK, Albert; NAYYAR, Gaura; LOW, Patrick. Supply Chain Perspectives - A Literature Review. Genebra: World Trade Organization; Hong Kong: Fung Global Institute, 2013.

PASTORE, Affonso C.; GAZZANO, Marcelo; PINOTTI, Maria C. Por que a produção industrial não cresce desde 2010? In: BACHA, Edmar; BAUMGARTEN, Monica B. (orgs.). O Futuro da Indústria no Brasil: desindustrialização em debate [recurso eletrônico]. Rio de Janeiro: Ed. Civilização Brasileira, 2013. Capítulo 5.

PATRIOTA, Antônio de Aguiar. "O Mercosul e a Integração Regional". Interesse Nacional, Ano 6, n. 23, out/dez. 2013.

PEREIRA, Lia Vallz. A "nova onda de regionalismo": uma reflexão sobre a agenda brasileira. Mural Internacional,, 4, jun. 2013. Disponível em: <http://www.epublicacoes.uerj.br/index.php/muralinternacional/article/view/6749>. Acesso em: 10 mar. 2015..

PEREIRA, Ruy. "O valor do Mercosul". Política Externa, vol. 22, n. 3, jan/fev/mar. 2014 , p. 21 - 29.

PIETERSE, Jan Nederveen; REHBEIN, Boike. (eds). Globalization and Emerging Societies: Development and Inequality. Hampshire/UK, New York/EUA: Palgrave Macmillan, 2009.

PIO, Carlos. Relações Internacionais: Economia Política e Globalização. Brasília: IBRI, 2002.

PONTES. "Governo anuncia medidas para aumentar competitividade internacional do Brasil". ICTSD, 30 set. 2014. Disponível em: <http://www.ictsd.org/bridgesnews/pontes/news/governo-anuncia-medidas-para-aumentar-competitividadeinternacional-do>. Acesso em: 17 nov. 2014. 
."Incentivos à indústria brasileira voltam a ser questionados na OMC". ICTSD, 8 out. 2014. Disponível em: <http://www.ictsd.org/bridgesnews/pontes/news/incentivos-\%C3\%A0-ind\%C3\%BAstria-brasileira-voltam-aser-questionados-na-omc>. Acesso em: 17 nov. 2014.

RASKIN, Amy; MELLQUIST, Nils. 'The New Industrial Revolution: Deverticalization on a Global Scale'. Research on Strategic Change. Alliance Bernstein, ago. 2005. Disponível em: <http://www.alliancebernstein.com/cmsobjectabd/pdf/research_whitepaper/r2845 3_deverticalization_051215.pdf>. Acesso em: 06 nov. 2014.

RESENDE, André Lara. Os Limites do Possível: a Economia além da Conjuntura. São Paulo: Portfolio-Penguin, 2013.

RICARDO, David. On the Principles of Political Economy and Taxation. Kitchener/ Canada: Batoche Books, 2001.

RIGGIROZZI, Pía; TUSSIE, Diana. (eds). The Rise of Post-Hegemonic Regionalism: The Case of Latin America. London and New York: Springer, 2012.

RIOS, Sandra Polónia. PANZINI, Fabrizio Sardelli. 'O pacote de Bali: implicações para a política comercial brasileira'. Revista Brasileira de Comércio Exterior, n. 118, Janeiro - Março de 2014, p. 40 - 53.

RODRIK, Dani. The Globalization Paradox: Democracy and the Future of the World Economy. New York: W. W. Norton \& Company, 2011.

Depois do Neoliberalismo, O Quê? In: CASTRO, Ana Célia. (Org). Desenvolvimento em Debate: Novos Rumos do Desenvolvimento no Mundo. Rio de Janeiro: BNDES, 2002. p. 277 - 298. Disponível em: <http://www.bndes.gov.br/SiteBNDES/export/sites/default/bndes_pt/Galerias/Arq uivos/conhecimento/livro_debate/1-DesenvGlob.pdf>. Acesso em: 15 jan. 2015.

. The Return of Industrial Policy. Project Syndicate, 12 abr. 2010. Disponível em: $\quad<$ http://www.project-syndicate.org/commentary/the-return-of-industrialpolicy>. Acesso em: 10 fev. 2015.

ROSECRANCE, Richard. The Rise of the Virtual State: Wealth and Power in the Coming State. New York: Basic Books, 1999.

ROUBINI, Nouriel. MIHN, Stephen. A Economia das Crises: um Curso Relâmpago sobre o Sistema Financeiro Internacional. Rio de Janeiro: Ed Intríseca, 2010.

SANDRONI, Paulo H. R. (org.). Novíssimo Dicionário de Economia. 3. ed. São Paulo: Best-Seller, 1999. p. 581-582. Disponível em: <http://sinus.org.br/2014/wpcontent/uploads/2013/11/FMI.BMNov\%C3\%ADssimo-Dicion\%C3\%A1rio-deEconomia.pdf $>$. Acesso em: 15 mar. 2015.

SATO, Eiiti. Economia e Política das Relações Internacionais. Belo Horizonte: Fino. Traço Editora, 2012.

A crise financeira internacional e as perspectivas para a economia brasileira. Revista On-Line Liberdade e Cidadania, v. II, p. 1-10, 2010. Disponível em: 
<http://www.flc.org.br/revista/arquivos/525363800510631.pdf>. Acesso em: 20 fev. 2015.

SHARMA, Ruchir. Breakout Nations: In Pursuit of the Next Economic Miracles. New York: Penguin Books, 2013.

. "The Ever-Emerging Markets: Why Economic Forecasts Fail".Foreign Affairs, January/ February, 2014.

Bearish on Brazil: The Commodity Slowdown and the End of the Magic Moment. Foreign Affairs, may/jun. 2012. Disponível em: <http://www.foreignaffairs.com/articles/137599/ruchir-sharma/bearish-on-brazil>. Acesso em: 02 mar. 2015

SLAUGHTER, Anne-Marie. "America's Edge: Power in the Networked Century", Foreign Affairs, January/February 2009.

SOARES DE LIMA, Maria Regina; COUTINHO, Marcelo V. Introdução - A América do Sul sob o Signo da Mudança. In: . (Org.). A Agenda SulAmericana: Mudanças e Desafios no Início do Século XXI. Brasília: FUNAG, $2007 . \quad$ Disponível em: <http://www.funag.gov.br/biblioteca/dmdocuments/A_Agenda\%20Sul_AMudeD esaf.pdf $>$. Acesso em: 20 jan. 2015.

SOUZA, Nali de Jesus de. Desenvolvimento Econômico. 7 ed. São Paulo: Atlas, 2012.

SOUZA, Nilson Araújo de. Economia Internacional Contemporânea. São Paulo: Atlas, 2009. p. 122-129.

SPEKTOR, Matias. Ideias de ativismo regional: a transformação das leituras brasileiras da região. Revista Brasileira de Política Internacional, vol. 53, issue 1, p. 25-44, 2010 .

SPENCE, Michael. Os Desafios do Futuro da Economia: o Crescimento Econômico Mundial nos Países Emergentes e Desenvolvidos. Tradução por Leonardo Abramowicz. Rio de Janeiro: Elsevier, 2011.

SQUEFF, Gabriel C. 'Desindustrialização: luzes e sombras no debate brasileiro'. IPEA Texto para discussão 1747. Brasília: jun. 2012.

STIGLITZ, Joseph E. Globalization and its Discontents. New York and London: W.W. Norton \& Company, 2002.

STIGLTZ, Joseph; GREENWALD, Bruce C. Creating a Learning Society: A New Approach to Growth, Develpment, and Social Progress. New York: Columbia University Press, 2014.

STURGEON, Timothy. et al. A Indústria Brasileira e as Cadeias Globais de Valor: uma análise com base nas indústrias aeronáutica, de eletrônicos e de dispositivos médicos. Confederação Nacional da Indústria. Rio de Janeiro: Elsevier; Brasília: Confederação Nacional da Indústria, 2014.

. 'O Brasil nas cadeias globais de valor: implicações para a política industrial e de comércio'. Revista Brasileira de Comércio Exterior, no 115, Abril - Junho de 
2013, $\quad$ p. $26 \quad$ - $41 . \quad$ Disponível em: <http://www.funcex.org.br/publicacoes/rbce/material/rbce/115_ TSGGAGEZ.pdf.pdf>. Acesso em: 23 out. 2014.

THE ECONOMIST. "A Continental Divide: The region is falling in behind two alternative blocks: the market-led Pacific Alliance and the more statist Mercosur.". May 18th $2013 . \quad$ Disponível em: $<$ http://www.economist.com/news/americas/21578056-region-falling-behind-twoalternative-blocks-market-led-pacific-alliance-and> Acesso em 23 Jul. 2013.

Everybody needs good neighbours. From the print edition: Finance and economics. Adelaide, 31 mar. 2011. Disponível em: <http://www.economist.com/node/18486183?story_id=18486183>. Acesso em: 07 fev. 2015.

. "The Growing Pacific Alliance: Join the club". Lima, 29/ 04/ 2013. Disponível em: <http://www.economist.com/blogs/americasview/2013/04/growing-pacificalliance > Acesso em 19 Jul. 2013.

. 'The new age of crony capitalism'. The Economist, 15 mar. 2014, p. 13; 57.

. "The Pacific players go to market: An incipient new club proclaims that Brazil is not South America's only game". Bogotá \& Lima, 7 de abril- 2011. Disponível em:<http://www.economist.com/node/18529807> Acesso em 16 de Jun. 2013.

THORSTENSEN, Vera. et al. 'A Multiplicação dos Acordos Preferenciais de Comércio e o Isolamento do Brasil'. Instituto de Estudos para Desenvolvimento Industrial (IEDI), jun. 2013. Disponível em: <http://retaguarda.iedi.org.br/ midias/artigos/51d18e9168afa9d0.pdf>. Acesso em: 23 out. 2014.

THORSTENSEN, Vera. FERRAZ, Lucas. 'O isolamento do Brasil em relação aos acordos e mega-acordos comerciais'. Livro Boletim de Economia e Política Internacional - IPEA, $\mathrm{n}^{\circ}$ 16, Janeiro/Abril 2014, p. 5- 17. Disponível em: < http://www.ipea.gov.br/portal/images/stories/PDFs/boletim_internacional/140512 _boletim_internacional016_cap1>. Acesso em: 23 out. 2014.

THORSTENSEN, Vera."Ficar atrelado ao Mercosul é afundar o Brasil". São Paulo: Carta Capital, 30 maio 2014. Entrevista concedida a Carlos Drummond. Disponível em: <http://www.cartacapital.com.br/economia/ficar-atrelado-aoMercosul-e-afundar-o-brasil-804.html > Acesso em 23/05/14.

TRATADO DE ASSUNÇÃO. 26 mar. 1991. MDIC. Disponível em: <http://www.desenvolvimento.gov.br/arquivos/dwnl_1270491919.pdf>. Acesso em: 17 jan. 2015.

UNCTAD. World Investment Report 2013. New York and Geneva: United Nations, 2013. Disponível em: <http://unctad.org/en/PublicationsLibrary/wir2013_en.pdf>. Acesso em: 17 mar. 2015.

UNITED STATES DEPARTMENT OF STATE. The United States' Participation as an Observer to the Pacific Alliance. Media Note. Office of the Spokesperson, Washington, DC: 19 jul. 2013. Disponível em: 
<http://www.state.gov/r/pa/prs/ps/2013/07/212205.htm>. Acesso em: 30 jan. 2015.

VARGAS LLOSA, Álvaro. Liberty for Latin America: how to undo five hundred years of state oppression. New York: Farrar, Straus and Giroux, 2005.

VEIGA, Pedro da Motta. (ed.). Revista Brasileira de Comércio Exterior, Rio de Janeiro, Funcex, n. 89, p. 2-3, out/dez. 2006.

VELOSO, Fernando. FERREIRA, Pedro C GIAMBIAGI, Fabio. PESSOA, Samuel. (eds.) Desenvolvimento Econômico: uma Perspectiva Brasileira. Rio de Janeiro: Elsevier, 2013.

VENABLES, Anthony J.; WINTERS, L. Alan. Economic Integration in the Americas: European Perspectives. In: ESTEVADEORDAL, Antoni. et al. (Org). Integrating the Americas: FTAA and Beyond. Cambridge, Massachusetts; London, England: Harvard University, David Rockefeller-Center for Latin American Studies, 2004. p. $75-101$.

VENEZUELA. Ministerio del Poder Popular de Planificación del Gobierno Bolivariano de Venezuela. Comercio Exterior. Disponível em: $<$ http://www.ine.gov.ve/index.php?option=com_content\&view=category\&id=48 \&Itemid=33>. Acesso em: 20 jan. 2015.

VIGEVANI, Tullo; ARAGUSUKU, Juliano A. S. Atitudes brasileiras para as organizações hemisféricas: Círculos concêntricos. Pensamiento Propio, ano 19, n. 39, jan./jun. 2014. Disponível em: <http://www.cries.org/wpcontent/uploads/2014/06/010-Vigevani.pdf >. Acesso em: 20 jan. 2015.

VIOLA, Eduardo; LEIS, Héctor Ricardo. Sistema internacional com hegemonia das democracias de mercado: desafios de Brasil e Argentina. Florianópolis: Insular, 2007, 232p.

VIOLA, Eduardo; FRANCHINI, Matias; RIBEIRO, Thais. Sistema Internacional de Hegemonia Conservadora: Governança Global e Democracia na Era da Crise Climática. São Paulo: Editora AnnaBlume, 2013.

VIOLA, Eduardo; PIO, Carlos. Doutrinarismo e Realismo na percepção do interesse nacional: política macroeconômica, segurança e Alca na relação Brasil-Estados Unidos. Cena Internacional. v. 5, n. 1, jun, 2003.

VIOLA, Eduardo; AYLLON, Bruno. Lula y el déficit de realismo estratégico en política exterior. Política Exterior (Madrid), v. 20, p. 123-134, 2006.

VIOLA, Eduardo; LIMA, Jean S. "Desafios para a Ascensão Chinesa no Sistema Internacional de Hegemonia das Democracias de Mercado". Carta Internacional (USP), v. 8, p. 116-136, 2014. Disponível em: < http://www.cartainternacional. abri.org.br/index.php/Carta/article/view/117/71> Acesso em 06 out. 2014.

WILLIAMSON, John. "What Washington Means by Policy Reform". In WILlIAMSON, J. (ed). Latin American Adjustment: How Much Has Happened? Washington: Institute for International Economics, 1990, Chapter 2. 
WOLF, Martin. 'Will the Nation-State Survive Globalization?'. Foreign Affairs, jan/feb. 2001. Disponível em: <http://www.foreignaffairs.com/articles/56665/martinwolf/will-the-nation-state-survive-globalization>. Acesso em: 24 out. 2014.

WOLFFENBÜTTEL, Andréa. O que é? Formação Bruta de Capital Fixo. IPEA, ano 1, ed. $3,2004 . \quad$ out. 12 Disponível em: $<$ http://ipea.gov.br/desafios/index.php?option=com_content $\&$ view $=$ article $\&$ id $=20$ 45: catid=28\&Itemid=23>. Acesso em 15 fev. 2015.

WORLD BANK. "Food Price Volatility, Food Security, and Trade Policy Conference". World Bank News, Feature Story, 14 out. 2014. Disponível em: <http://www.worldbank.org/en/news/feature/2014/10/14/food-price-volatilityfood-security-and-trade-policy-conference>. Acesso em: 26 jan. 2015.

WORLD ECONOMIC FORUM (WEF). Global Competitiveness Report 2014-2015. Disponível em: <http://www3.weforum.org/docs/WEF_GlobalCompetitivenessReport_201415.pdf >. Acesso em: 20 fev. 2015.

WORLD ECONOMIC FORUM (WEF). 'Mega-regional Trade Agreements: gamechangers or costly distractions for the world trading system?'. Global Agenda Council on Trade \& Foreign Direct Investment, jul. 2014. Disponível em: <http://www3.weforum.org/docs/GAC/2014/WEF_GAC_TradeFDI_Mega RegionalTradeAgreements_Report_2014.pdf>. Acesso em: 23 out. 2014.

WORLD TRADE ORGANIZATION (WTO). Annual Report 2014. Disponível em: https://www.wto.org/english/res_e/booksp_e/anrep_e/anrep14_e.pdf: Acesso em: 28 fev. 2015.

WTO. IDE-JETRO. Trade Patterns and global value chains in East Asia: From trade in goods to trade in tasks. 2011. Disponível em: <http://www.wto.org/english/res_e/booksp_e/stat_tradepat_globvalchains_e.pdf>. Acesso em: 07 nov. 2014.

ZAKARIA, Fareed. The Post-American World. New York/London: Norton \& Company, 2008. 292p.

ZANOTTO, Andrade. Propostas de integração externa da indústria. Pontes (Bridges Networks), v. 10, n. 6, ago. 2014. p. 9-11. 